\title{
RESPONSABILIDADE PELA ENTREGA E PELOS VÍCIOS DA COISA NA INCORPORAÇÃO IMOBILIÁRIA
}

\author{
Dissertação apresentada à Banca Examinadora, no \\ âmbito do Programa de Pós-Graduação da Faculdade \\ de Direito da Universidade de São Paulo, como \\ exigência parcial para a obtenção do título de mestre \\ em Direito, sob orientação da Professora Doutora \\ Daisy Gogliano.
}

FACULDADE DE DIREITO DA UNIVERSIDADE DE SÃO PAULO SÃO PAULO

2014 
Heloisa Martins Granja

\section{RESPONSABILIDADE PELA ENTREGA E PELOS VÍCIOS DA COISA NA INCORPORAÇÃO IMOBILIÁRIA}

\begin{abstract}
Dissertação apresentada à Banca Examinadora, no âmbito do Programa de Pós-Graduação da Faculdade de Direito da Universidade de São Paulo, como exigência parcial para a obtenção do título de mestre em Direito, sob orientação da Professora Doutora Daisy Gogliano.
\end{abstract}

Área de concentração: Direito Civil

Data de defesa:

Resultado:

\section{Banca Examinadora}

Prof. (a) Dr. (a) Daisy Gogliano

Instituição: Universidade de São Paulo

Prof. (a) Dr. (a)

Instituição:

Prof. (a) Dr. (a)

Instituição: 
Dedico este trabalho

À minha mãe, pelo esforço contínuo e incentivo aos

estudos.

Ao Paulo e àqueles que considero parte da minha família, por acreditarem e apoiarem, cada um à sua maneira. 


\section{AGRADECIMENTOS}

Agradeço, em especial, à Professora Daisy, pelo ato de confiança e pela orientação conferida no decorrer deste trabalho.

Agradeço a todos que, de diferentes formas, fizeram parte desta trajetória, compartilhando experiências ou proferindo palavras de incentivo. 


\section{RESUMO}

Em razão da crescente relevância do setor imobiliário no Brasil, este estudo tem por objetivo verificar a proteção dada aos adquirentes de imóveis na incorporação imobiliária, em relação à entrega da coisa, abrangendo tanto as hipóteses de atraso quanto as de vícios no imóvel. Para tanto, serão abordadas questões relacionadas à incorporação imobiliária, inclusive seu surgimento, tipificação e características essenciais; às obrigações do incorporador no que se refere à entrega da coisa; e ao conteúdo das normas protetivas aplicáveis aos adquirentes.

Palavras chave: "Incorporação Imobiliária”. Responsabilidade. Entrega. Imóvel. Atrasos. Vícios. 


\begin{abstract}
Due to the rising relevancy of the real estate sector in Brazil, this study aims at the verifying the protection assured nowadays to the purchasers of properties in the Brazilian system of "incorporação imobiliária", with regard to the delivery of the apartment, including the hypothesis of delay in such delivery and of defective apartments. In this sense, it shall be studied issues relating to the "incorporação imobiliária" system, especially its construction and development, its definition by law and its essential characteristics; the obligations of delivery in such system; and the content of the applicable laws.
\end{abstract}

Keywords: Incorporação Imobiliária. Liability. Real Estate. Delivery. Delay. Defective. 


\section{SUMÁRIO}

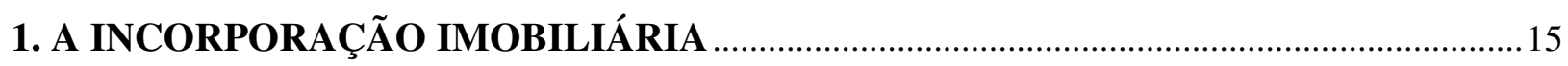

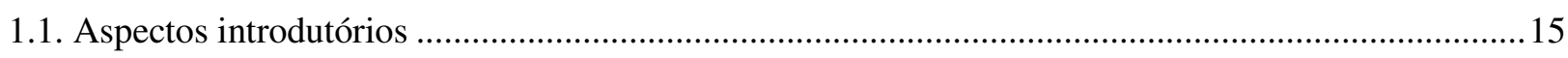

1.1.1. A incorporação imobiliária em outros ordenamentos jurídicos ................................................. 19

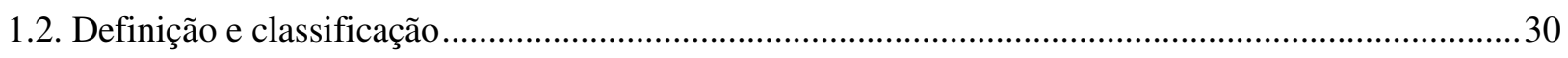

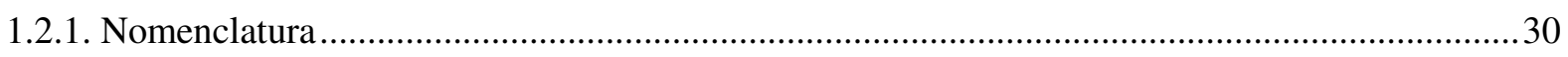

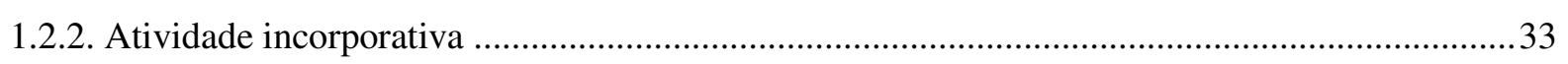

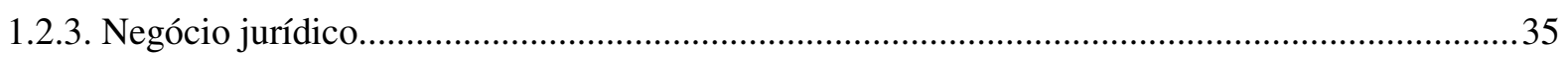

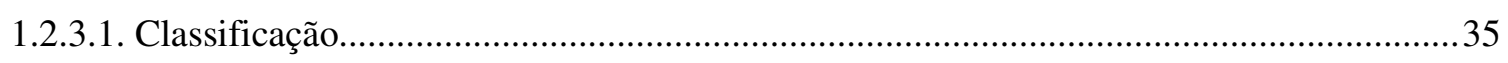

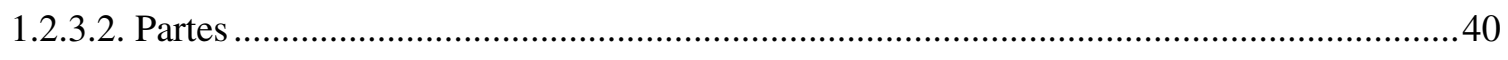

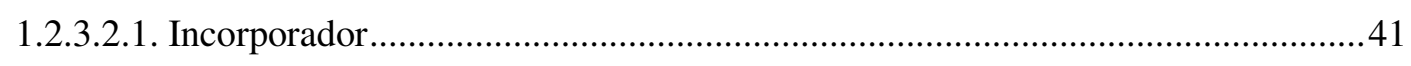

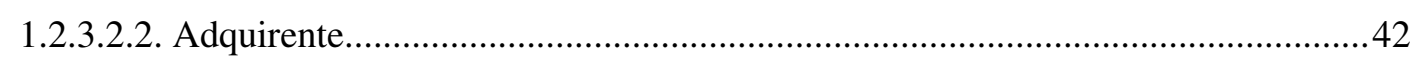

1.2.3.2.2.1. Representação dos adquirentes - Comissão de Representantes e

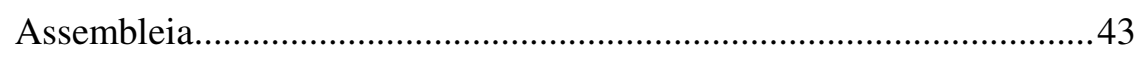

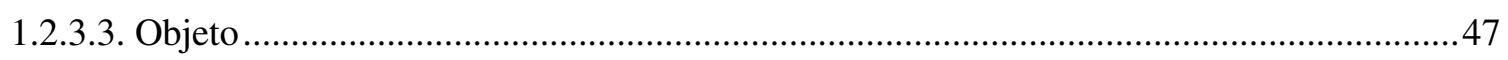

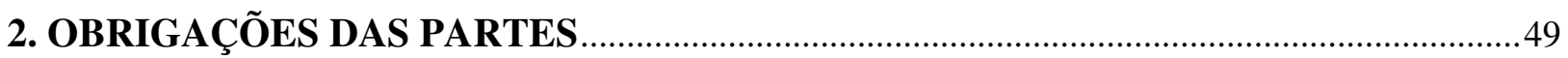

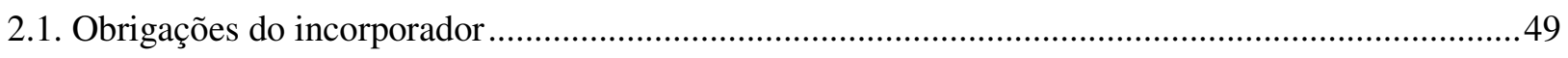

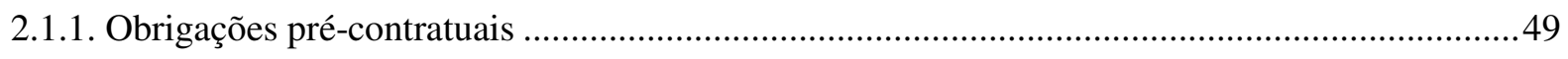

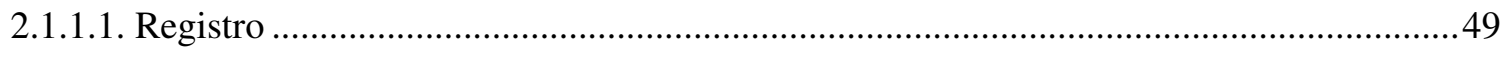

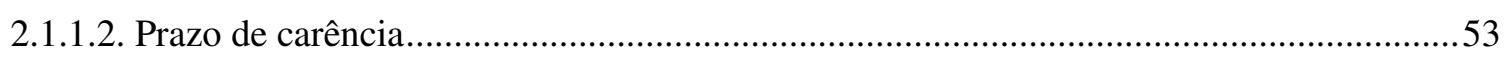

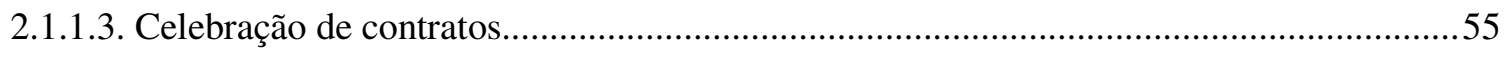

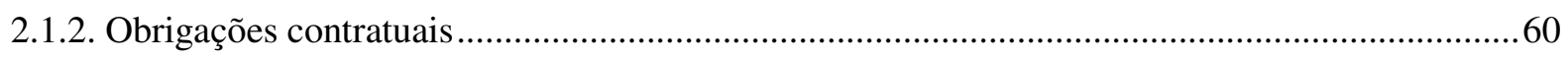

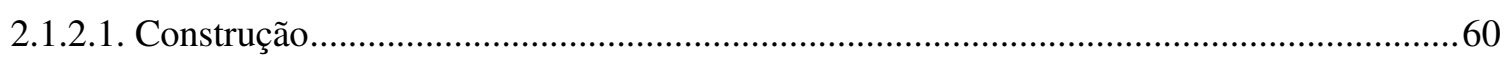

2.1.2.2. Entrega da obra e transferência da propriedade .............................................................66

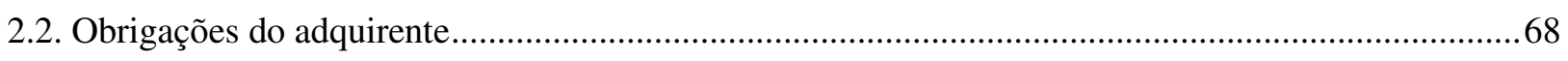

2.2.1. Pagamento

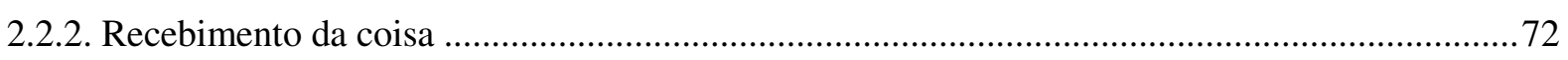

3. APLICAÇÃO DO CÓDIGO DE DEFESA DO CONSUMIDOR ........................................74

3.1. O Código de Defesa do Consumidor .......................................................................................... 74

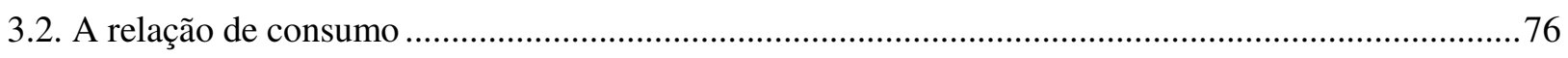

3.3. Cotejo entre a Lei n ${ }^{\circ} 4.591 / 64$, o Código Civil e o Código de Defesa do Consumidor .......................79 


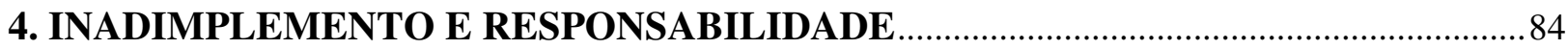

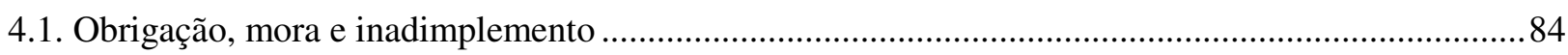

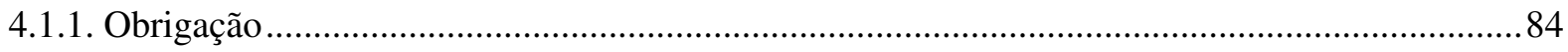

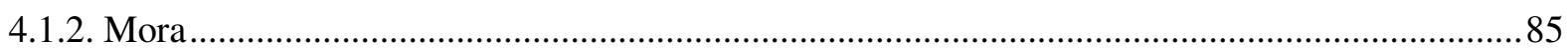

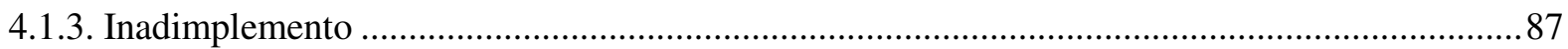

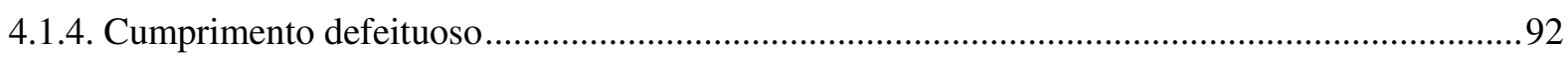

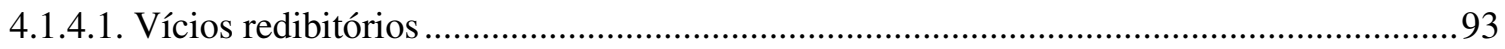

4.1.4.1.1. Regulação pelo Código Civil ...........................................................................96

4.1.4.1.2. Regulação pelo Código de Defesa do Consumidor............................................ 105

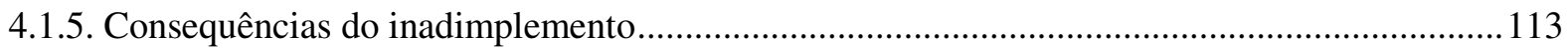

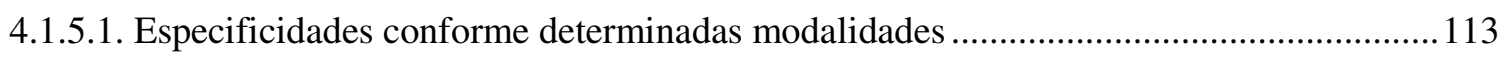

4.1.5.2. Enjeitamento prestação e redução da contraprestação ………………………………..... 116

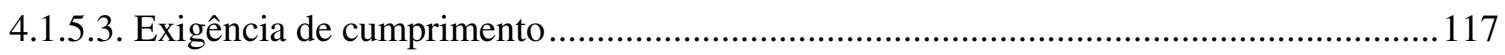

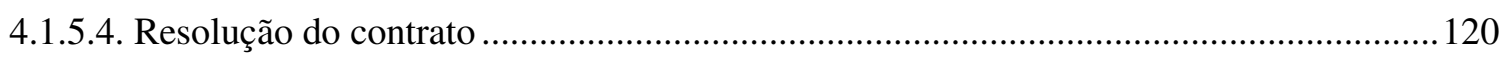

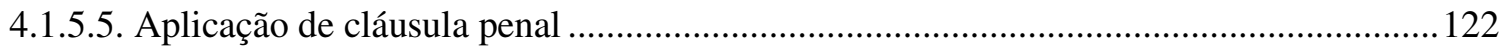

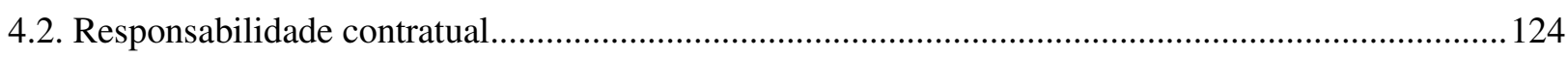

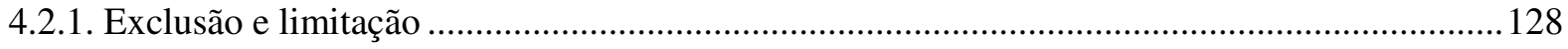

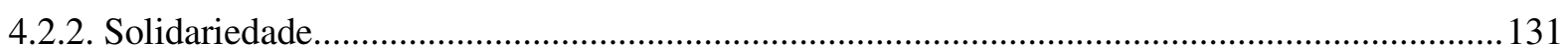

5. RESPONSABILIDADE PELA ENTREGA E PELOS VÍCIOS DA COISA NA

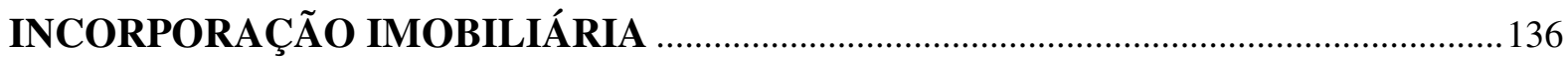

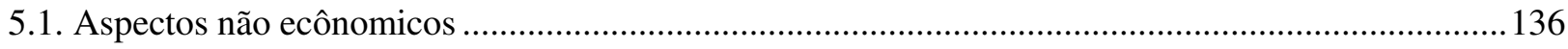

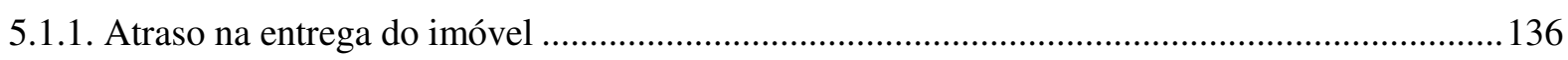

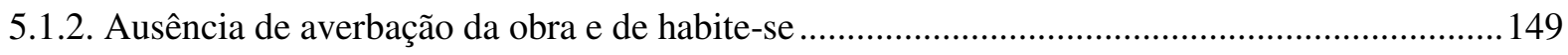

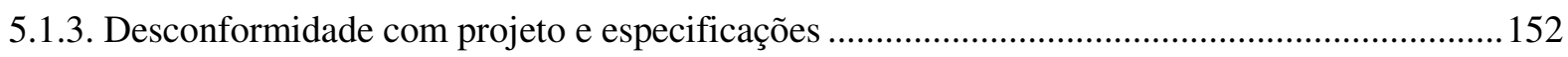

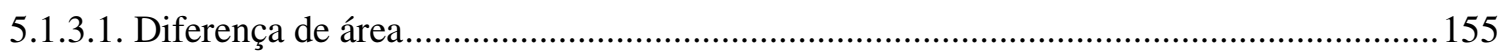

5.1.4. Responsabilidade pela solidez e segurança da obra ............................................................... 164

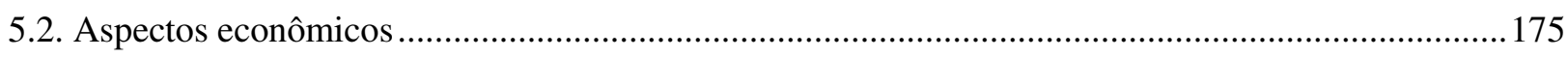

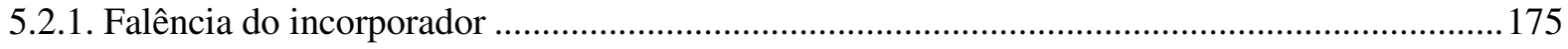

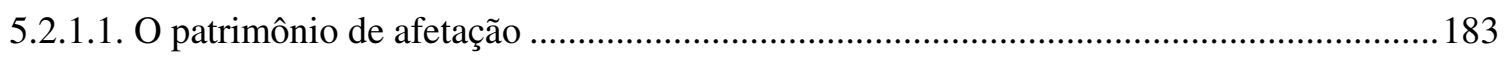

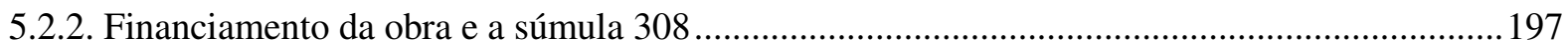

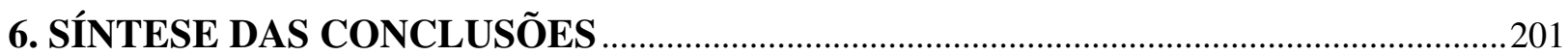

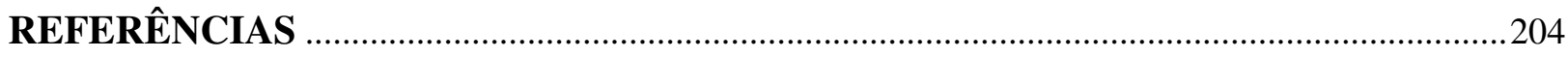




\section{INTRODUÇÃO}

A incorporação imobiliária é resultado da evolução das relações de propriedade, especialmente em decorrência da urbanização e consequente carência de espaço apropriável.

Verificou-se, principalmente a partir do século XIX, o problema habitacional, cujo agravamento levou à superposição de unidades imobiliárias e à proliferação de edifícios em regime condominial.

O edifício de múltiplos andares possibilitou o progresso das cidades, multiplicou a utilização imobiliária e desdobrou economicamente o sentido útil da propriedade, conforme Caio Mário da Silva Pereira ${ }^{1}$.

Nesse sentido, a propriedade imobiliária, que, no direito tradicional era vertical e abrangia o solo, o subsolo e a faixa superior à superfície ${ }^{2}$, deu lugar à propriedade horizontal $^{3}$, figura jurídica atrelada à multiplicação da utilização imobiliária e à própria consagração da incorporação imobiliária.

Não obstante haver entendimentos de que a propriedade horizontal existiu em épocas mais remotas ${ }^{4}$, previamente ao período romano, pode-se afirmar que seu desenvolvimento até a configuração hodierna ocorreu nos últimos séculos.

A propriedade horizontal, configurada pela divisão da edificação em unidades autônomas e isoladas entre si, pela propriedade exclusiva sobre tais unidades e pelo condomínio sobre o que for de uso comum, e sua aplicação crescente

\footnotetext{
${ }^{1}$ PEREIRA, Caio Mário da Silva. Condomínio e incorporações. 6. ed. Rio de Janeiro: Forense, 1991. p. 85.

${ }^{2}$ A verticalidade da propriedade definia que esta se estendia, verticalmente, e era acompanhada de convicção legal de que pertencia ao dono do solo tudo aquilo que estivesse acima ou abaixo dele: "aedificium solo cedit et ius soli sequitur".

${ }^{3}$ Deve-se interpretar a propriedade horizontal como instituto autônomo, havendo combinação da propriedade exclusiva e do condomínio, sendo tanto a propriedade quanto o condomínio conceito de amplo domínio no Direito, quando pensados isoladamente. Contudo, a aplicação isolada das normas de cada um dos institutos não reflete a verdade fática. Na lição de Caio Mario da Silva Pereira, "Somente esta simbiose orgânica dos dois conceitos, na criação de um direito complexo, é que oferece justificativa precisa aos direitos e deveres dos condôminos.”. PEREIRA, Caio Mário da Silva. Condomínio e incorporações, cit., p. 93.

${ }^{4}$ Para melhor compreensão do assunto, veja-se BATALHA, Wilson de Souza Campos. Loteamentos $e$ condomínios: sistema jurídico da propriedade fracionada. 2. ed. Rio de Janeiro: Livraria Freitas Bastos, 1959. t. 1; PONTES DE MIRANDA, Francisco Cavalcanti. Tratado de direito privado. Campinas: Ed. Bookseller, 2003. t. 26; e MARCHI, Eduardo da Silveira B. A propriedade horizontal no direito romano. 2. ed. São Paulo: Quartier Latin, 2006.
} 
como solução ao problema habitacional verificado, ensejou a paulatina regulação do instituto em diversos países ${ }^{5}$.

No Brasil, o Decreto no 5481/28 inovou o ordenamento jurídico, rompendo o regime do condomínio tradicional.

Apesar da regulação acima indicada, o crescimento populacional nas grandes cidades brasileiras intensificou-se nos meados do século $\mathrm{XX}$, em razão do processo de industrialização e urbanização acelerado.

Nesse cenário, a incorporação imobiliária surgiu como fenômeno fático, por atuação dos empreendedores da época, sem a devida regulação legal, até a edição da Lei $\mathrm{n}^{\circ}$ 4.591/64, que finalmente a instituiu e estruturou, além de regular, de forma mais premente, a propriedade horizontal (ou condomínio especial $\left.{ }^{6}\right)^{7}$.

Sob a ótica econômico-social, a incorporação imobiliária permitiu a criação de um forte setor baseado na construção de imóveis em condomínio e a tentativa de solucionar a crise populacional e habitacional, problema intrínseco à sociedade moderna, expandindo as possibilidades de aquisição de propriedade pelos membros da sociedade.

O setor imobiliário e o de construção tiveram crescimento acelerado no Brasil, especialmente na última década, em razão da estabilidade econômica, do aumento do mercado de consumo brasileiro, da facilidade de obtenção de crédito pelos

\footnotetext{
${ }^{5}$ As primeiras codificações não previam a propriedade horizontal e foram, nos meados do século XX, sendo alteradas para abarcar a regulamentação específica da propriedade horizontal. Veja-se, a esse respeito, PEREIRA, Caio Mário da Silva. Propriedade horizontal. Rio de Janeiro: Forense, 1961.

${ }^{6}$ Há diversas designações para o instituto: condomínio relativo; condomínio de edifícios com apartamentos autônomos; condomínio por andares ou apartamentos; propriedade em planos horizontais; condomínios e incorporações; condomínio em edifícios, comunhão pro diviso, como acima citado, entre outras. A Exposição de Motivos do Código Civil brasileiro e os artigos de tal Código fazem referência ao termo "condomínio edilício", justificando seu uso por ser resultado do ato de edificação. Em razão das diversas críticas à utilização de tal denominação, será referido, neste trabalho, como condomínio especial ou em edificações.

${ }^{7} \mathrm{Há}$ autores que distinguem a propriedade horizontal do condomínio especial, pois aquela pressupõe somente a pluralidade de unidades privativas, podendo haver, assim, apenas um proprietário de tais unidades privativas, e o condomínio especial exige a pluralidade de sujeitos, tendo como pressuposto a própria propriedade horizontal, ou seja, a divisão da coisa em unidades privativas. Para maiores detalhes, ver as seguintes obras: MEZZARI, Mario Pazutti. Condomínio e incorporação no registro de imóveis. 3. ed. Porto Alegre: Norton Editor, 2010. p. 30; CHALHUB, Melhim Namem. Alienação fiduciária, incorporação imobiliária e mercado de capitais: estudos e pareceres. Rio de Janeiro: Renovar, 2012 p. 380-381; FRANCO, João Nascimento; GONDO Nisske. Incorporações imobiliárias. São Paulo: Ed. Revista dos Tribunais, 1972. Apesar da exatidão técnica do conceito de propriedade horizontal, de que independe da pluralidade subjetiva, pode-se afirmar que não apresenta utilidade prática à constituição de instituto tão relevante quanto a propriedade horizontal se não para permitir a pluralidade ou abarcar a pluralidade de sujeitos, não apenas para se referir à divisão da coisa em unidades, motivo pelo qual trataremos como conceitos similares.
} 
consumidores, de incentivo por parte do governo e, repise-se, do problema habitacional nas grandes cidades.

Deve-se destacar que o problema habitacional é de grande severidade, tendo o constituinte, inclusive, optado por incluir o direito a moradia como direito fundamental, de ordem social, ao lado da educação, saúde, alimentação etc. ${ }^{8}$

Os problemas relacionados à incorporação imobiliária, ainda que antigos, intensificaram-se, o que se afirma diante do patente aumento de reclamações advindas da incorporação imobiliária.

Como exemplo, em 2011, o PROCON-SP registrou mais de 4.300 reclamações ou pedidos de informações de adquirentes de imóveis em face das incorporadoras/construtoras ${ }^{9}$, sendo que, até 10 de maio de 2012, esse número ultrapassava $3.015^{10}$.

Os motivos geradores das reclamações são diversos, mas se repetem amiúde: atraso na entrega do imóvel ${ }^{11}$, em descumprimento dos prazos estipulados contratualmente; entrega de imóvel com especificações diversas das inicialmente previstas, inclusive em relação às dimensões do imóvel; má qualidade da construção, no que se incluem vícios, defeitos, vazamentos, impermeabilização etc.; cobrança de juros pela incorporadora previamente à entrega do imóvel, entre tantos outros motivos ${ }^{12}$.

\footnotetext{
${ }^{8} \mathrm{~A}$ moradia é uma proteção garantida pelo art. $6 .^{\circ}$ da Constituição Federal, relativo aos direitos sociais, sendo uma das exteriorizações do princípio de proteção da dignidade da pessoa humana. Ressalte-se que o elemento moradia é fundamental, inclusive na definição das hipóteses de usucapião, assegurando-se maior proteção (ou proteção em menor tempo), se o uso de um imóvel for para fins de moradia, conforme arts. 183 e 191da Constituição Federal e 1.238 a 1.244 do Código Civil, exemplificativamente. Os contratos imobiliários, como a incorporação imobiliária, são os principais meios de consecução da moradia.

${ }^{9}$ Informação obtida no site da FUNDAÇÃO PROCON-SP. Assunto: Incorporação (Construtoras e Incorporadoras). Disponível em: <http://www.procon.sp.gov.br/pdf/acs_construtoras_2008_2011.pdf>. Acesso em: 13 jun. 2012.

${ }^{10}$ Tal número foi atualizado até 17.05.12, conforme notícia divulgada no site da FUNDAÇÃO PROCON-SP. Construtoras mais reclamadas. Disponível em: <http://www.procon.sp.gov.br/noticia.asp?id=3027>. Acesso em: 13 jun. 2012. No primeiro semestre de 2013, foram registrados em tal órgão 1076 reclamações relacionadas, sendo 408 relativas a não entrega e 52 relativas a qualidade do bem e vícios, conforme FUNDAÇÃO PROCON-SP. Ranking - CIPs. Incorporação (Construtoras e Incorporadoras). $1^{\circ}$ sem 2013. Disponível em: <http://www.procon.sp.gov.br/pdf/ranking\%20incorporadoras_2013.pdf>. Acesso em: 126 nov. 2013.

${ }^{11}$ Acerca do atraso na entrega do imóvel, em notícia acima citada, o diretor executivo do PROCON/SP, Paulo Arthur Góes, assim comentou: “As reclamações sobre atrasos na entrega estão aumentando e preocupam. Tentamos negociar a solução do problema junto às construtoras, mas se isso não for possível as empresas são autuadas pelo abuso.".

${ }^{12} \mathrm{De}$ acordo com o PROCON/SP, as principais queixas em 2011 foram o não cumprimento do contrato/proposta, dúvidas sobre cobranças (taxas etc.), cobrança de taxa indevida (elaboração de contrato, aferição de idoneidade etc.), qualidade da construção (vícios, defeitos, vazamentos, impermeabilização etc.), devolução de sinal e de valores pagos (negócio não concretizado).
} 
Verifica-se, pois, que as principais queixas estão atreladas à entrega do imóvel.

Dessa forma, considerando o reiterado descumprimento de obrigações na entrega dos imóveis pelas incorporadoras e a importância, na economia brasileira, do mercado imobiliário e de setores a ele ligados, sustentados pelo fortalecimento da incorporação imobiliária, a necessidade de estudo do tema apresenta-se nítida, especialmente no que se refere à responsabilidade pela entrega e pelos vícios da coisa na incorporação imobiliária.

A escolha do tema que nos propomos a estudar baseia-se, ademais, na aparente inexistência de medidas efetivas para se evitar a reiteração dos problemas vividos pelos adquirentes de imóveis no que se refere à entrega da coisa, considerando-se, inclusive, a relevância constitucional do direito à moradia.

Para a devida compreensão do que se pretende neste estudo e em razão da amplitude do tema, é necessário que se faça a delimitação do objeto do trabalho, sob pena de se perder o enfoque proposto.

É imprescindível a caracterização e conceituação da incorporação imobiliária, resvalando, minimamente, em conceitos ligados à propriedade horizontal, inclusive porque a incorporação imobiliária é considerada como uma das formas de instituição do condomínio especial.

Na conceituação e caracterização da incorporação imobiliária, analisaremos sua definição legal e a distinção entre atividade incorporativa e o negócio jurídico da incorporação; seus elementos objetivos e subjetivos; e outros elementos importantes, decorrentes da Lei $n^{\circ} 4.591 / 64$.

Posteriormente, com base no disposto em lei, passaremos à análise das obrigações das partes na incorporação imobiliária.

O enfoque do trabalho, contudo, é a responsabilidade pela entrega da coisa. Não nos limitaremos à análise do atraso na entrega do imóvel, sendo relevante a compreensão de casos (i) de entrega inadequada, em desconformidade com o projeto correspondente, o que abrange a entrega de imóvel com vícios e defeitos, qualitativos e quantitativos; (ii) nos quais não se cumpram requisitos para a entrega do imóvel, como os relacionados à averbação da construção ou à obtenção do "habite-se"; e (iii) em que há impedimento, em razão, por exemplo, da decretação da falência ou da insolvência civil do incorporador, ou inadimplemento deste em relação ao contrato de financiamento da obra. 
Nesse contexto, além do conteúdo normativo da Lei no 4.591/64, será avaliada a incidência de outras normas à relação entre os adquirentes de imóveis e as partes atuantes na incorporação imobiliária, inclusive do Código de Defesa do Consumidor, ainda que não seja objetivo deste trabalho minuciar o sistema de proteção ao consumidor por ele instituído.

Em razão da complexidade do tema e da diversidade de aspectos jurídicos a ele relacionados, alguns assuntos podem ser tratados de maneira aparentemente pouco profunda, o que se impõe de forma a delimitar o escopo deste estudo.

Não serão aprofundados, neste trabalho, aspectos relacionados à propriedade e ao condomínio, ainda que a incorporação possa ensejar a instituição do condomínio especial, nem os relacionados a aspectos processuais.

Ademais, não pretendemos tratar de outros ramos do direito, como o previdenciário, trabalhista ou tributário. O direito constitucional será mencionado, mas não tratado extensamente em razão da inexistência de contradição com as normas constitucionais $^{13}$. O aspecto penal será superficialmente tratado, em razão de a lei da incorporação imobiliária trazer em seu bojo a caracterização de infrações penais.

Apesar da verificação do disposto em lei acerca do patrimônio de afetação, não será objeto deste trabalho a análise aprofundada do conceito jurídico da afetação patrimonial ou do tema da securitização, ainda que se possa indicar sua relação com a incorporação imobiliária.

\footnotetext{
${ }^{13}$ Ainda que o assunto deste trabalho relacione-se a aspectos constitucionais quando a aquisição for realizada por adquirente para fins de habitação, entendemos desnecessário realizar a análise apurada dos preceitos constitucionais. O direito constitucional à moradia, como outros direitos e princípios de ordem constitucional, pode limitar a autonomia privada, havendo o embate entre a tutela dos direitos fundamentais e a salvaguarda da autonomia privada, conforme cita Daniel Sarmento, em A vinculação dos particulares aos direitos fundamentais no direito comparado e no Brasil. In: BARCELLO, Ana Paula et al (Orgs.). A nova interpretação constitucional: ponderação, direitos fundamentais e relações privadas. Rio de Janeiro: Renovar, 2003. p. 194. Dessa forma, o incorporador não pode, pretensiosamente com base na autonomia privada, estipular condições que venham a afetar a garantia constitucional. Entendendo-se que a ordem constitucional não pode ser ferida pelas normas infraconstitucionais, que devem, sim, se coadunar com aquela, tem-se que diante de conflito entre normas, pode-se apelar pelo recurso de julgamento da ponderação. Contudo, entendemos não haver qualquer conflito entre a garantia do direito à moradia, prevista na Constituição Federal, e as normas aplicáveis à incorporação imobiliária, tendo em vista que estas são voltadas à proteção dos adquirentes e, consequentemente, na hipótese de aquisição para fins de moradia, à afirmação do direito constitucional pela norma infraconstitucional. Ademais, ainda que, conforme Daniel Sarmento, A vinculação dos particulares aos direitos fundamentais no direito comparado e no Brasil, cit., p. 278, a essencialidade do bem seja um critério importante para aferição da intensidade da proteção conferida à autonomia privada, devemos ter em mente que o direito à moradia não corresponde necessariamente ao direito à propriedade, sendo certo que há alcance da norma constitucional relativa à moradia, ainda que o imóvel não seja próprio. Pelos motivos expostos, reiteramos entendimento de desnecessidade de avaliação de tal norma constitucional e sua interpretação na doutrina e na jurisprudência.
} 
Pretende-se analisar a existência de regramentos estrangeiros similares ao existente atualmente no Brasil, verificando-se eventuais soluções existentes a problemas relacionados à entrega da coisa em sistemas correspondentes à incorporação imobiliária em outros países.

O estudo a que nos propomos será estruturado também pela análise de julgados relacionados ao tema aqui tratado, de forma a verificar as soluções determinadas pelos julgadores pátrios. Limitar-nos-emos à jurisprudência de tribunais superiores brasileiros e de determinados tribunais estaduais. 


\section{A INCORPORAÇÃO IMOBILIÁRIA}

\subsection{Aspectos introdutórios}

A incorporação imobiliária resultou da evolução das relações de propriedade, especialmente da urbanização e superpopulação urbana e da consequente ausência de espaço apropriável.

Uma das soluções encontradas ao problema habitacional foi a construção vertical de grandes edificações, para melhor aproveitamento do solo, em aparente conflito com preceitos antigos $^{14}$.

Surgiu, assim, o conceito de propriedade horizontal, que se constituía em contraposição à propriedade vertical do direito tradicional, contrariando, inicialmente, o absolutismo e a exclusividade que permeavam a propriedade e o conceito romano "superfície solo cedit".

A propriedade horizontal, que se afasta do princípio clássico atinente à propriedade, pelo qual pertencia a uma só pessoa tudo aquilo que estivesse acima ou abaixo do solo, é caracterizada pela existência de propriedade exclusiva sobre unidades autônomas e isoladas entre si e pela configuração do condomínio sobre o que for de uso comum.

A partir do século XX, surgiram regulamentações específicas da propriedade horizontal, inclusive no sentido de alterar normas contrárias editadas até então.

O Código Civil de 1916 havia desprezado o instituto da divisibilidade por andares ${ }^{15}$. Contudo, o Decreto-Lei $\mathrm{n}^{\mathrm{o}} 5.481 / 28^{16}$ passou a prever a propriedade horizontal e

\footnotetext{
${ }^{14}$ Como o da verticalidade da propriedade, definindo-se como "usque ad profundum e usque ad coelum: cuius est solum, eius est usque ad coelum, usque ad inferos" (Glossa ad L. 22, paragrafo 4º, Dig. XLIII, 24), que foi representado pela maioria das legislações até o Século XX.

${ }^{15}$ Não obstante, Pontes de Miranda afirmava que, apesar de o Código Civil de 1916 não prever expressamente essa questão, havia a permissão para reconhecimento da comunhão pro diviso, que seria a abreviação de "comunhão no terreno e nas partes indivisas do edifício e mais dependências e não-comunhão nas partes pro diviso", "propriedades distintas, domínios sem condomínio, estão próximas e ligadas ou circundadas pela comunhão de alicerces, tetos, paredes (...) etc.", sendo, pois, "misto de comunhão e de não-comunhão, de divisão e de indivisão" (PONTES DE MIRANDA, Francisco Cavalcanti. Tratado de direito predial. 2. ed. Rio de Janeiro: J. Konfino, 1953. v. 2, p. 28-37).

${ }^{16}$ Segundo Everaldo Cambler, tal decreto colocou o País em situação pioneira ao sistematizar a propriedade coletiva. CAMBLER, Everaldo Augusto. Incorporação imobiliária: ensaio de uma teoria geral. São Paulo: Ed. Revista dos tribunais, 1993. p. 31.
} 
permitiu a alienação de apartamentos em edifícios com mais de cinco andares, sendo esse número reduzido, posteriormente, para três ou mais e para dois ou mais pavimentos, respectivamente pelo Decreto - Lei ${ }^{\circ}$ 5.234/1943 e pela Lei ${ }^{\circ}$ 285/1948.

Referido ordenamento refletia uma solução superficial ao problema habitacional, pois, exemplificativamente, não abrangia todos os edifícios existentes, havendo limitação de sua incidência a edifícios com determinado número de pavimentos.

Paralelamente, verificou-se, na prática, a atividade da incorporação imobiliária, uma vez que empreendedores passaram, de forma deliberada, a construir e alienar, durante a construção, unidades autônomas ou direitos sobre elas, ensejando a criação da figura do incorporador no mundo dos negócios ${ }^{17}$.

A incorporação imobiliária nasceu da prática da atividade de construção de edificações e venda de unidades autônomas durante a construção, sem que houvesse ainda regulação específica.

Conforme explana Orlando Gomes, o exercício de tal "atividade profissional através de relações contratuais tão frequentes e importantes" ensejou a tipificação do negócio jurídico denominado contrato de incorporação imobiliária ${ }^{18}$.

Uma vez que não havia regulação da incorporação imobiliária, tinha-se, previamente à edição da Lei $\mathrm{n}^{\circ}$ 4.591/64, um cenário caracterizado pela completa desproteção aos adquirentes de imóveis em construção.

Nas palavras de Caio Mario ${ }^{19}$ :

E foi precisamente porque faltava uma caracterização exata para a sua atuação, como porque o negócio da incorporação não tinha a natureza de um contrato nominado, é que não havia pronunciamentos seguros da justiça a seu respeito.

A ausência de proteção advinha, também, da indefinição quanto ao papel do incorporador, havendo, naquela época, grande confusão em relação às obrigações deste.

\footnotetext{
${ }^{17}$ No Brasil essa foi a solução criada. Contudo, nos Estados Unidos e na Suíça preferiu-se o sistema de cooperativas, por meio do qual uma sociedade é construtora e proprietária da edificação e aluga apartamentos ou andares a longo prazo aos associados, segundo Everaldo Cambler, em Incorporação imobiliária: ensaio de uma teoria geral, cit., p. 90.

${ }^{18}$ GOMES, Orlando. Contratos. 26. ed. Rio de Janeiro: Forense, 2008. p. 549.

${ }^{19}$ PEREIRA, Caio Mário da Silva. Condomínio e incorporações, cit., p. 234.
} 
Assim, em face da insuficiência da legislação anterior, que não previa a figura da negociação de unidade autônoma em edificação pendente de construção, e da necessidade de se albergar o aumento crescente da população urbana, tornou-se imprescindível solução adequada ao problema da habitação nas grandes cidades, ocasionando, pois, a edição da Lei $\mathrm{n}^{\circ} 4.591$ de 1964.

A lei foi fruto das reformas do regime militar, "com vistas à implementação de um programa de desenvolvimento da construção civil, e portanto, da geração de emprego e de superação do déficit habitacional num país que se urbanizava rapidamente (...)"20.

Desse modo, o legislador disciplinou tanto a incorporação imobiliária, antes desenvolvida sem tipificação legal, quanto o condomínio especial, que até aquele momento era regulado por legislação de incidência limitada.

A junção, em uma só lei, da incorporação imobiliária e do condomínio especial justifica-se pelo fato de ser a incorporação citada pela maior parte dos doutrinadores como forma de instituição do condomínio especial ${ }^{21}$.

Em regra, a instituição do condomínio especial é ato de vontade do proprietário do prédio ou do terreno, que pode decidir fazer a individualização das unidades, mediante escritura pública a ser registrada no Cartório de Registro de Imóveis competente, atendendo aos requisitos do art. 1.332 do Código $\mathrm{Civil}^{22}$.

Para sua instituição ou constituição, é necessário que sejam observados os elementos caracterizadores do instituto: o elemento objetivo, que é a propriedade e o condomínio nas edificações; o subjetivo, que implica pluralidade de sujeitos na propriedade; e o institucional, de forma a regular as relações entre o objeto e os sujeitos.

\footnotetext{
${ }^{20}$ FRANCISCO, Caramuru Afonso. O novo regime jurídico dos contratos: das incorporações e do registro imobiliário e da alienação fiduciária em garantia. São Paulo: Juarez de Oliveira, 2005. p. 59.

${ }^{21}$ Exemplificativamente, Maria Helena Diniz, em Curso de direito civil brasileiro: direito das coisas. 19. ed. São Paulo: Saraiva, 2004. v. 4, p. 218.

${ }^{22}$ Art. 1.332. Institui-se o condomínio edilício por ato entre vivos ou testamento, registrado no Cartório de Registro de Imóveis, devendo constar daquele ato, além do disposto em lei especial:

I - a discriminação e individualização das unidades de propriedade exclusiva, estremadas uma das outras e das partes comuns;

II - a determinação da fração ideal atribuída a cada unidade, relativamente ao terreno e partes comuns;

III - o fim a que as unidades se destinam.
} 
Ressalte-se que os artigos do Código Civil aplicáveis ao condomínio especial referem-se tanto à instituição do condomínio, quanto à sua constituição por meio da convenção, que, por sua vez, definirá o regimento interno ${ }^{23}$.

Segundo Mezzari, é o registro da instituição do condomínio que cria as unidades autônomas, e não a existência física destas ${ }^{24}$.

Para citado autor, a incorporação imobiliária não é, por si só, instituidora do condomínio especial, pois, para tanto, há necessidade de registro da instituição do condomínio, sendo o regime da incorporação hábil a pré-submeter o imóvel ao regime da propriedade horizontal $^{25}$.

Não obstante o entendimento contrário, a incorporação enseja a instituição do condomínio $^{26}$, já que esta é resultado do processo de incorporação, sendo uma das obrigações do incorporador o registro da minuta da convenção do condomínio.

Contudo, para que se verifique, de fato, a incorporação imobiliária, deve haver alienação de unidades futuras antes da conclusão das obras.

Um dos elementos essenciais à incorporação imobiliária é a construção da edificação e sua segmentação em unidades autônomas, para aquisição por diversos adquirentes de tais unidades a serem constituídas.

Conforme leciona Orlando Gomes ${ }^{27}$, só há caracterização do contrato de incorporação se a edificação for segmentada em unidades autônomas e a venda destas ocorrer durante a fase de planejamento e construção, uma vez que, se a "edificação é

\footnotetext{
${ }^{23} \mathrm{O}$ art. 1.332 refere-se à instituição e o art. 1.333, a seguir colacionado, refere-se à constituição: “Art. 1.333. A convenção que constitui o condomínio edilício deve ser subscrita pelos titulares de, no mínimo, dois terços das frações ideais e torna-se, desde logo, obrigatória para os titulares de direito sobre as unidades, ou para quantos sobre elas tenham posse ou detenção.”. No direito português, há menção à constituição da propriedade horizontal, como definido no Código Civil português, e ao regulamento, contido no título constitutivo: O art. 1.417 do Código Civil Português assim dispõe: "1. A propriedade horizontal pode ser constituída por negócio jurídico, usucapião ou decisão judicial, proferida em acção de divisão de coisa comum ou em processo de inventário.".

${ }^{24}$ MEZZARI, Mario Pazutti. Condomínio e incorporação no registro de imóveis, cit., p. 55, 149 e 154.

${ }^{25}$ Segundo o autor, duas são as modalidades de pré-instituição em condomínios e pré-atribuição de unidades conhecidas pelo direito brasileiro: a incorporação imobiliária e a existência de grupo de condôminos especialmente reunidos para edificar um empreendimento nos moldes da propriedade horizontal. Para ele, se trata da "prehorizontalidade", denominação mais utilizada por doutrinadores estrangeiros, conforme explana na obra citada, p. 76 e ss.

${ }^{26}$ Maria Helena Diniz inclui expressamente a incorporação imobiliária como forma de instituição de condomínio em edificação, além da destinação do proprietário do edifício, o testamento, a constituição do regime por vários herdeiros, a arrematação em hasta pública, doação ou compra de frações do edifício e a sentença judicial em ação de divisão, em Curso de direito civil brasileiro: direito das coisas, cit., p. 218-219.

${ }^{27}$ GOMES, Orlando. Contratos, cit., 26. ed., 2008, p. 549.
} 
adquirida, sem autonomia das unidades, por várias pessoas, o contrato de aquisição não é de incorporação", assim como não é incorporação a venda da unidade após a conclusão das obras ${ }^{28}$.

\subsubsection{A incorporação imobiliária em outros ordenamentos jurídicos}

$\mathrm{Na}$ Itália, a venda de imóveis em construção, que, em tal país, é denominada acquisto di immobili da costruire ou sulla carta, é realizada por meio de celebração de contrato preliminar de venda, havendo igualmente a antecipação de receitas para o construtor, pelo pagamento do preço pelo adquirente, e posterior entrega da coisa construída ${ }^{29}$.

$\mathrm{Na}$ década de 70, houve iniciativa legislativa para regular essa atividade, que restou infrutífera. Posteriormente, em razão da fragilidade dos adquirentes ${ }^{30}$, da relevância constitucional do direito a habitação e da falência de uma empresa de construção na Itália (de forma semelhante ao Brasil), foi editada a Lei $n^{\circ}$ 30/1997, que introduziu ao Código Civil italiano o art. 2645-bis ${ }^{31}$, prevendo a transcrição do contrato preliminar de venda ou

\footnotetext{
${ }^{28}$ Assim, uma das essenciais características da incorporação imobiliária é, como citado anteriormente, a alienação de unidades autônomas previamente à sua construção, vinculando-se eventual direito a coisa futura, ou, conforme art. 29 da Lei de Incorporação, compromissando-se ou se efetivando a venda de frações ideais de terreno objetivando a vinculação de tais frações a unidades autônomas futuras.

${ }^{29}$ CILENTO, Antonio. L'acquisto di immobili in costruzione tra rischio econômico e tutela della persona. Napoli: Edizioni Scientifiche Italiane, 2010. p. 33. (Collana: Quaderni dela Rassegna di diritto civile).

${ }^{30}$ Aos adquirentes não era permitida a obtenção do contrato definitivo por meio da ação de execução forçada de obrigação de fazer prevista no art. 2.931 do Código Civil italiano, além de que, em caso de falência do construtor/incorporador, tinham os adquirentes somente direito de crédito dos valores pagos pelo bem jamais entregue. Conforme CARDARELLI, Sergio. L'acquisto di immobili da costruire o in corso di costruzione. Milano: Giuffrè, 2009. p. 15.

31“"Art. 2645-bis. Trascrizione di contratti preliminari - 1. I contratti preliminari aventi ad oggetto la conclusione di taluno dei contratti di cui ai numeri 1), 2), 3) e 4) dell'articolo 2643, anche se sottoposti a condizione o relativi a edifici da costruire o in corso di costruzione, devono essere trascritti se risultano da atto pubblico o da scrittura privata con sottoscrizione autentica o accertata giudizialmente. 2. La trascrizione del contratto definitivo o di altro atto che costituisca comunque esecuzione dei contratti preliminari di cui al comma 1, ovvero della sentenza che accoglie la domanda diretta ad ottenere l'esecuzione in forma specifica dei contratti preliminari predetti, prevale sulle trascrizioni ed iscrizioni eseguite contro il promittente alienante dopo la trascrizione del contratto preliminare. 3. Gli effetti della trascrizione del contratto preliminare cessano e si considerano come mai prodotti se entro un anno dalla data convenuta tra le parti per la conclusione del contratto definitivo, e in ogni caso entro tre anni dalla trascrizione predetta, non sia eseguita la trascrizione del contratto definitivo o di altro atto che costituisca comunque esecuzione del contratto preliminare o della domanda giudiziale di cui all'articolo 2652, primo comma, numero 2). 4. I contratti preliminari aventi ad oggetto porzioni di edifici da costruire o in corso di costruzione devono indicare, per essere trascritti, la superficie utile della porzione di edificio e la quota del diritto spettante al promissario acquirente relativa all'intero costruendo edificio espressa in millesimi. 5. Nel caso previsto nel comma 4 la trascrizione è eseguita con riferimento al bene immobile per la quota
} 
outro contrato translativo ou constitutivo de direito real de uso de bem em construção ${ }^{32}$, o que demanda, segundo parágrafo $4^{\circ}$ de tal artigo, que o contrato preliminar indique "la superficie utile della porzione di edificio e la quota del diritto spettante al promissario acquirente relativa all'intero costruendo edificio espressa in millesimi.”.

Aludido artigo prevê que prevalecerá o registro do contrato definitivo sobre qualquer outro registro feito após o contrato preliminar correspondente ao definitivo, desde que o registro seja realizado em até um ano da data prevista para conclusão do definitivo ou até três anos do registro do contrato preliminar.

Como mais uma garantia em face da quebra de contrato preliminar, referida lei introduziu, conforme art. 2.775-bis do mesmo Código ${ }^{33}$, um privilégio especial sobre o imóvel, tratando-se de privilégio de crédito do promitente-adquirente, caso haja escolha do curador da falência pelo término do contrato preliminar de venda, o que será analisado quando da verificação de hipóteses que impedem a entrega do imóvel ${ }^{34}$.

Como os adquirentes continuavam expostos aos riscos do negócio, inclusive da falência do incorporador, o legislador preocupou-se mais recentemente em regular a venda de imóveis em construção na Itália, editando o Decreto Legislativo no ${ }^{\mathbf{o}} 122 / 2005^{35}$, que trouxe definição de garantias e proteções ao adquirente, como a devolução de valores pagos pelo adquirente em caso de situações de crise do incorporador e o seguro com

determinata secondo le modalità di cui al comma stesso. Non appena l'edificio viene ad esistenza gli effetti della trascrizione si producono rispetto alle porzioni materiali corrispondenti alle quote di proprietà predeterminate nonché alle relative parti comuni. L'eventuale differenza di superficie o di quota contenuta nei limiti di un ventesimo rispetto a quelle indicate nel contratto preliminare non produce effetti. 6 . Ai fini delle disposizioni di cui al comma 5, si intende esistente l'edificio nel quale sia stato eseguito il rustico, comprensivo delle mura perimetrali delle singole unità, e sia stata completata la copertura."

${ }^{32}$ Previamente, o contrato preliminar era meramente obrigacional, conforme MEZZASOMA, Lorenzo. Il "Consumatore" acquirente di immobili da costruire fra diritto al risparmio e diritto all abitazione. Napoli: Edizioni Scientifique Italiane, 2008. p. 50. (Collana: Consumatori Oggi, 21).

${ }^{33}$ CILENTO, Antonio. L'acquisto di immobili in costruzione tra rischio econômico e tutela della persona, cit., p. 20. E CARDARELLI, Sergio. L'acquisto di immobili da costruire o in corso di costruzione. Milano: Giuffrè, 2009. p. 15 e ss.

${ }^{34}$ MEZZASOMA, Lorenzo. Il "Consumatore" acquirente di immobili da costruire fra diritto al risparmio e diritto all'abitazione, cit., p. 54 e TRIOLA, Roberto. Vendita di immobili da costruire e tutela dell'acquirente. Milano: Giuffrè, 2005. p. 157.

${ }^{35}$ Tal decreto é decorrência da Lei $\mathrm{n}^{\circ} 210$ de 2004 , que previu que fosse editado decreto no prazo de seis meses daquela norma, indicando a preocupação do legislador italiano de proteger o adquirente de imóvel em construção, principalmente por se tratar, geralmente, de aquisição para habitação e, conforme explana Cliento, Antonio, ob. Cit., p. 74, por haver assimetria na relação jurídica entre adquirente e incorporador, em razão de ser a coisa futura e por sua existência depender da solvência do vendedor. 
cobertura para danos decorrentes de vícios graves de construção, assim como a determinação do conteúdo mínimo do contrato atinente ${ }^{36}$.

Veja-se que o art. $6^{\circ}$ de referido normativo ${ }^{37}$ define que o contrato deverá conter a descrição do imóvel, inclusive da parte de uso exclusivo, os elementos técnicos da construção, preço e forma de pagamento, o prazo máximo para término da construção, bem como informações atinentes a ônus, como a hipoteca ${ }^{38}$.

Tal normativo define as pessoas do adquirente $\mathrm{e}^{39}$ e do incorporador ${ }^{40}$ e o conceito

${ }^{36}$ Como explana Lorenzo Mezzasoma, a norma em questão traz, em suma, além das três citadas previsões, garantias atinentes a subdivisão de financiamento da obra e a obrigação do registrário de cancelar ou fracionar hipoteca antes do registro do contrato com o adquirente, previsão que permite que o adquirente opte pela garantia de devolução dos valores pagos antes da escolha do curador pelo término do contrato preliminar com o adquirente, o que será analisado em capítulo oportuno; direito de preferência do adquirente em caso de venda em leilão do bem prometido em venda; e a criação de fundo de solidariedade que beneficia a todos os adquirentes e é composto por valores pagos pelos incorporadores. MEZZASOMA, Lorenzo. Il "Consumatore" acquirente di immobili da costruire fra diritto al risparmio e diritto all'abitazione, cit., p. 65 e ss.

${ }^{37}$ Gaetano Petrelli explana que a ratio do art. $6^{\circ}$ da norma em questão é voltada a "finalizzate a renderei 1 piu possible determinata la prestazione costruttiva avente ad oggeto il fabbricato da edificare e lo stato di fatto e di diritto di quest ultimo, a prescindere dal momento del trasferimento dela proprieta.". Em Gli acquisiti di immobili da costruire. Milano: Ed. Ipsoa, 2005. p. 22.

${ }^{38}$ Conforme art. $1^{\text {o: }}$ " 1 . Il contratto preliminare ed ogni altro contratto che ai sensi dell'articolo 2 sia comunque diretto al successivo acquisto in capo ad una persona fisica della proprietà o di altro diritto reale su un immobile oggetto del presente decreto devono contenere: $a$ ) le indicazioni previste agli articoli 2659, primo comma, n. 1), e 2826 del codice civile; $b$ ) la descrizione dell'immobile e di tutte le sue pertinenze di uso esclusivo oggetto del contratto; $c$ ) gli estremi di eventuali atti d'obbligo e convenzioni urbanistiche stipulati per l'ottenimento dei titoli abilitativi alla costruzione e l'elencazione dei vincoli previsti; $d$ ) le caratteristiche tecniche della costruzione, con particolare riferimento alla struttura portante, alle fondazioni, alle tamponature, ai solai, alla copertura, agli infissi ed agli impianti; $e$ ) i termini massimi di esecuzione della costruzione, anche eventualmente correlati alle varie fasi di lavorazione; $f$ ) l'indicazione del prezzo complessivo da corrispondersi in danaro o il valore di ogni altro eventuale corrispettivo, i termini e le modalità per il suo pagamento, la specificazione dell'importo di eventuali somme a titolo di caparra; le modalità di corresponsione del prezzo devono essere rappresentate da bonifici bancari o versamenti diretti su conti correnti bancari o postali indicati dalla parte venditrice ed alla stessa intestati o da altre forme che siano comunque in grado di assicurare la prova certa dell'avvenuto pagamento; $g$ ) gli estremi della fideiussione di cui all'articolo 2 ; $h$ ) l'eventuale esistenza di ipoteche o trascrizioni pregiudizievoli di qualsiasi tipo sull'immobile con la specificazione del relativo ammontare, del soggetto a cui favore risultano e del titolo dal quale derivano, nonche' la pattuizione espressa degli obblighi del costruttore ad esse connessi e, in particolare, se tali obblighi debbano essere adempiuti prima o dopo la stipula del contratto definitivo di vendita; $i$ ) gli estremi del permesso di costruire o della sua richiesta se non ancora rilasciato, nonche' di ogni altro titolo, denuncia o provvedimento abilitativo alla costruzione; $l$ ) l'eventuale indicazione dell'esistenza di imprese appaltatrici, con la specificazione dei relativi dati identificativi. (...)".

${ }^{39}$ A norma não protege pessoa jurídica e empresa adquirente, ampliando a abrangência em relação ao código de defesa do consumidor italiano, que prevê aplicação a pessoa física, mas desde que não aja no âmbito de sua atividade empresarial, comercial ou profissional, conforme Lorenzo Mezzasoma, Il "Consumatore" acquirente di immobili da costruire fra diritto al risparmio e diritto all abitazione, cit., p. 69 e ss. Ressaltese, oportunamente, entendimento majoritário da doutrina italiana, que, segundo Antonio cilento p. 140 e 141, é no sentido de favorecer a interpretação da destinação objetiva do bem ou serviço, de forma a evitar abrangência excessiva da noção de consumidor.

${ }^{40}$ A definição abrange o alienante, que pode ser o construtor ou não, desde que a construção não seja a cargo do próprio adquirente: "sia nel caso in cui lo stesso venga edificato diretamente dai medesimi sia nel caso in cui la realizzazione dela costrzione sia data in appalto o comunque eseguita da terzi". PETRELLI, Gaetano. Gli acquisiti di immobili da costruire, cit., p. 33. 
de imóvel em construção ${ }^{41}$, de forma a estipular seu campo de aplicação, sendo requisito para tanto que o imóvel em construção já possua a permissão de construção, mas que não esteja em estado tal que permita a obtenção do "certificato di agibilità",42, semelhante ao "habite-se" no direito brasileiro ${ }^{43}$.

Infere-se, portanto, que a Itália tratou de prever determinadas proteções ao ao adquirente de imóveis em construção, sem, contudo, regular minuciosamente a venda de tais imóveis como fez o legislador brasileiro.

Na França, o assunto é regulado pela lei nº 67, de 03 de janeiro de 1967, que criou e alterou artigos do Código Civil francês.

Exemplificativamente, referida lei introduziu os artigos 1.601-1 a 1.601-4, de forma a estabelecer dois tipos de vendas: a "vente à terme", sendo a prazo, em que não há pagamento antecipado (durante as obras), sendo que a transferência de propriedade ocorre automaticamente com a "escritura de conclusão do edifício", com efeito retroativo à data da venda ${ }^{44}$; e outra, mais usual, denominada "en l'état futur d'achèvement" ${ }^{45}$, que trata da

\footnotetext{
41، 1 . Ai fini del presente decreto devono intendersi: a) per «acquirente»: la persona fisica che sia promissaria acquirente o che acquisti un immobile da costruire, ovvero che abbia stipulato ogni altro contratto, compreso quello di leasing, che abbia o possa avere per effetto l'acquisto o comunque il trasferimento non immediato, a se' o ad un proprio parente in primo grado, della proprietà o della titolarità di un diritto reale di godimento su di un immobile da costruire, ovvero colui il quale, ancorche' non socio di una cooperativa edilizia, abbia assunto obbligazioni con la cooperativa medesima per ottenere l'assegnazione in proprietà o l'acquisto della titolarità di un diritto reale di godimento su di un immobile da costruire per iniziativa della stessa; $b$ ) per «costruttore»: l'imprenditore o la cooperativa edilizia che promettano in vendita o che vendano un immobile da costruire, ovvero che abbiano stipulato ogni altro contratto, compreso quello di leasing, che abbia o possa avere per effetto la cessione o il trasferimento non immediato in favore di un acquirente della proprietà o della titolarità di un diritto reale di godimento su di un immobile da costruire, sia nel caso in cui lo stesso venga edificato direttamente dai medesimi, sia nel caso in cui la realizzazione della costruzione sia data in appalto o comunque eseguita da terzi; $(\ldots)$. d) per «immobili da costruire»: gli immobili per i quali sia stato richiesto il permesso di costruire e che siano ancora da edificare o la cui costruzione non risulti essere stata ultimata versando in stadio tale da non consentire ancora il rilascio del certificato di agibilità.

${ }^{42}$ Conforme definição do art. 24, parágrafo $1^{\circ}$, do DPR (Decreto do Presidente) no 380 de 2001: "il certificato di agibilita atesta la sussistenza dele condizioni di sicurezza, igiene, salubrità, risparmio energetico degli edifici e degli impianti negli stessi installati, valuate secondo quando dispone la normativa vigente".

${ }^{43}$ Veja-se que o decreto prevê não haver aplicação se não houver requerimento da permissão para construir. Conforme Petrelli, os imóveis em construção sem permissão de construção "non possono essere commercializzati", gerando a ilicitude do contrato, de forma que não se proteja interesse do construtor em detrimento do interesse do adquirente (PETRELLI, Gaetano. Gli acquisiti di immobili da costruire, cit., p. 23 e 30-31). De forma parecida, mas não idêntica à Lei $\mathrm{n}^{\circ} 4.591 / 64$, que prevê que, para que o incorporador comercialize unidades, deve haver o registro do memorial de incorporacão.

${ }^{44} \mathrm{Em}$ relação a esse tipo de contrato, a lei, em seu artigo $8^{\circ}$, prevê que os depósitos de garantia só poderão ser realizados em conta vinculada aberta em nome do comprador, ficando os valores depositados indisponíveis, podendo ser utilizados somente para pagamento do preço, conforme redação original: "Le contrat de vente à terme peut seulement stipuler que des dépôts de garantie seront faits, à mesure de l'avancement des travaux, à un compte spécial ouvert au nom de l'acquéreur par un organisme habilité à cet effet. Les fonds ainsi déposés sont incessibles, insaisissables et indisponibles dans la limite des sommes dues par l'acheteur, sauf pour le paiement du prix.".

${ }^{45} \mathrm{O}$ mesmo artigo $8^{\circ}$ define que, em relação a este contrato, não pode haver pagamentos antes da assinatura do contrato como se infere da seguinte redação: "Dans le cas de vente en l'état futur d'achèvement, le
} 
venda em estado futuro, havendo transferência imediata do direito sobre o solo e de cada parte construída, à medida em que é construída ${ }^{46}$.

Citada lei dispôs sobre a determinação de responsabilidade do vendedor por vícios aparentes e por vícios relacionados à solidez da obra, como será visto oportunamente.

O conteúdo do contrato é determinado pelo art. $7^{\circ}$ da lei em questão ${ }^{47}$, devendo aquele ser formalizado por escritura pública e especificar a descrição do imóvel, inclusive por meio de anexo ou referência a documento registrado em cartório que indique suas características técnicas, o preço e condições de pagamento e de revisão, prazo de entrega, a garantia de conclusão da obra e reembolso de valores, as condições de eventual

vendeur ne peut exiger ni accepter aucun versement, aucun dépôt, aucune souscription ou acceptation d'effets de commerce avant la signature du contrat, ni avant la date à laquelle la créance est exigible.”.

${ }^{46}$ Tal previsão está contida no art. 1.601-1, que assim dispõe: "La vente d'immeubles à construire est celle par laquelle le vendeur s'oblige à édifier un immeuble dans un délai déterminé par le contrat. Elle peut être conclue à terme ou en l'état futur d'achèvement.". As definições de cada uma das formas de venda, contudo, estão dispostas nos artigos 1.601-2 e 1.601-3, respectivamente: "La vente à terme est le contrat par lequel le vendeur s'engage à livrer l'immeuble à son achèvement, l'acheteur s'engage à en prendre livraison et à en payer le prix à la date de livraison. Le transfert de propriété s'opère de plein droit par la constatation par acte authentique de l'achèvement de l'immeuble ; il produit ses effets rétroactivement au jour de la vente." e "La vente en l'état futur d'achèvement est le contrat par lequel le vendeur transfère immédiatement à l'acquéreur ses droits sur le sol ainsi que la propriété des constructions existantes. Les ouvrages à venir deviennent la propriété de l'acquéreur au fur et à mesure de leur exécution ; l'acquéreur est tenu d'en payer le prix à mesure de l'avancement des travaux. Le vendeur conserve les pouvoirs de maître de l'ouvrage jusqu'à la réception des travaux.”.

${ }^{47}$ Conforme art. $7^{\circ}$, cuja redação é a seguinte: "Lorsque le vendeur a fait état des prêts destinés au financement de la construction, le contrat doit être conclu sous condition résolutoire pour le cas de nonobtention de ceux-ci.

Il doit être conclu par acte authentique et préciser: a) la description de l'immeuble ou de la partie d'immeuble vendu; b) son prix et les modalités de paiement de celui-ci; c) le délai de livraison; d) lorsqu'il revêt la forme prévue à l'article 1.601-3 du code civil, la garantie de l'achèvement de l'immeuble ou du remboursement des versements effectués en cas de résolution du contrat à défaut d'achèvement.

Toutefois, lorsque la vente concerne une partie d'immeuble, le contrat peut ne comporter que les indications propres à cette partie, les autres précisions prévues à l'alinéa précédent doivent alors figurer soit dans un document annexé à l'acte, soit dans un document déposé au rang des minutes d'un notaire et auquel l'acte fait référence.

Il doit également mentionner si le prix est ou non révisable et, dans l'affirmative, les modalités de sa révision.

Il doit en outre comporter en annexe, ou par référence à des documents déposés chez un notaire, les indications utiles relatives à la consistance et aux caractéristiques techniques de l'immeuble.

Le règlement de copropriété est remis à chaque acquéreur lors de la signature du contrat; il doit lui être communiqué préalablement.

Lorsque, avant la conclusion de la vente, le vendeur a obtenu le bénéfice d'un prêt spécial du Crédit foncier de France ou du Comptoir des entrepreneurs, le contrat doit mentionner que l'acheteur a été mis en état de prendre connaissance, dans des conditions fixées par décret, des documents relatifs à l'équilibre financier de l'opération, au vu desquels a été prise la décision de prêt.

L'inobservation des dispositions du présent article entraîne la nullité du contrat. Cette nullité ne peut être invoquée que par l'acquéreur et avant l'achèvement des travaux." 
financiamento obtido pelo incorporador, além de haver obrigação deste de entregar as regras atinentes ao condomínio ${ }^{48}$.

Na hipótese de descumprimento de qualquer das citadas obrigações, há previsão de nulidade do contrato, que só pode ser invocada pelo adquirente antes da entrega da obra, nos termos do mesmo art. $7^{\circ}$.

As partes podem celebrar contrato preliminar de reserva do imóvel ("contrat préliminaire de reservation"), conforme art. 11 da lei citada ${ }^{49}$ e art. 266-3 do Code de la construction et de l'habitation $^{50}$. Mediante tal contrato reserva-se o imóvel a ser

\footnotetext{
${ }^{48}$ Ressalte-se que o art. 222-3 do Code de la construction et de l'habitation também prevê condições relativas ao contrato, sendo causa de invalidade do contrato de promoção imobiliária o não cumprimento de referido artigo: "Le contrat de promotion immobilière doit être constaté, avant le commencement de son exécution, par un écrit contenant les énonciations qui suivent: a) La situation et la contenance du terrain sur lequel doit être édifié le bâtiment; b) La consistance et les caractéristiques techniques du bâtiment à construire; c) Les devis descriptifs et les conditions d'exécution techniques des travaux; d) Le prix convenu ainsi que les limites et conditions dans lesquelles la révision du prix peut intervenir; si un poste pour imprévu est inclus dans le prix et si le contrat ne subordonne pas l'utilisation des sommes correspondantes à un accord préalable du maître de l'ouvrage, le promoteur doit, en fin d'opération, restituer à ce dernier la totalité des sommes qui auraient été appelées et dont il ne peut pas justifier avoir eu besoin pour exécuter sa mission; e) Les moyens et conditions de financement et les modalités de règlement à mesure de l'avancement des travaux; f) La rémunération du promoteur pour ses soins, peines et débours; g) Le délai dans lequel le bâtiment doit être édifié; h) La garantie apportée par le promoteur pour la bonne exécution de sa mission.

Par dérogation aux dispositions qui précèdent, le contrat peut être constaté par plusieurs actes séparés comportant chacun des énonciations limitées à une phase ou à une partie de l'ensemble des opérations à réaliser. Toutefois, aucun travail matériel, hormis ceux nécessaires aux études préliminaires, ne peut être effectué sur le terrain avant la signature des actes concernant toutes les opérations à réaliser.

L'inobservation des dispositions du présent article entraîne la nullité du contrat de promotion immobilière. Cette nullité ne peut être invoquée que par le maître de l'ouvrage et jusqu'à l'achèvement des travaux.

Elle entraîne l'inopposabilité au maître de l'ouvrage des contrats passés par le promoteur.".

${ }^{49}$ “La vente prévue à l'article 6 ci-dessus peut être précédée d'un contrat préliminaire par lequel, en contrepartie d'un dépôt de garantie effectué à un compte spécial, le vendeur s'engage à réserver à un acheteur un immeuble ou une partie d'immeuble.

Ce contrat doit comporter les indications essentielles relatives à la consistance de l'immeuble, à la qualité de la construction et aux délais d'exécution des travaux ainsi qu'à la consistance, à la situation et au prix du local réservé.

Les fonds déposés en garantie sont indisponibles, incessibles et insaisissables jusqu'à la conclusion du contrat de vente. Ils sont restitués, dans le délai de trois mois, au déposant si le contrat n'est pas conclu du fait du vendeur ou si le contrat proposé fait apparaître une différence anormale par rapport aux prévisions du contrat préliminaire.

Est nulle toute autre promesse d'achat ou de vente."

${ }^{50}$ Trata-se de norma ampla que regula a divisão imobiliária, o condomínio, as atividades das empresas ligadas à construção, requisitos para construção, seguros e definição de responsabilidade, como a quanto a vícios da edificação, fazendo referência a diversas estipulações contidas no próprio Código Civil, como aquelas atinentes a vícios de solidez, à definição do contrato de "promotion immobilière", contrato pelo qual uma pessoa obriga-se perante o dono da obra a realizar, por um preço acordado, a implementação de um empreendimento de um ou mais edifícios etc. No caso da "promotion immobilière", qualquer contrato pelo qual uma pessoa se obriga a realizar construção de um edifício residencial ou um prédio comercial e habitação, em uma capacidade diferente de vendedor ou as referidas no parágrafo $3^{\circ}$ do artigo 1.779 do Código Civil, está sujeito às regras dos artigos 1.831-1 a 1.831-5 do mesmo Código, reproduzido nos artigos L. 221-1 a L. 221-5 do Código e as disposições do presente capítulo. Verifique-se a definição da pessoa do promoteur tanto pelo art. 1.831-1 do Código Civil francês quanto pelo art. 221-1do Code de la construction et de l'habitation: "Le contrat de promotion immobilière est un mandat d'intérêt commun par lequel une personne dite " Promoteur immobilier " s'oblige envers le maître d'un ouvrage à faire procéder, pour un prix convenu, au moyen de contrats de louage d'ouvrage, à la réalisation d'un programme de
} 
construído, mediante depósito em garantia pelo adquirente, sendo que tal valor, como sinal, deve ser feito em conta específica e é impenhorável, criando-se, assim, um patrimônio de afetação ${ }^{51}$.

Como se trata de venda que permite a desistência pelo incorporador, caso este entenda que o mercado não é apropriado, há obrigação específica de devolução do valor pago pelo pretenso adquirente na hipótese de desistência do empreendimento ou se não houver celebração do contrato definitivo no prazo de três meses.

Para coibir atitudade dessa espécie, previu o legislador que qualquer pessoa que, tendo recebido ou aceito um ou mais pagamentos, desvie tais valores, ainda que parcialmente, será punido nos termos do artigo 408 do Código Penal ${ }^{52}$.

Ressalte-se que o art. 222-5 do Code de la construction et de l'habitation ${ }^{53}$ prevê que o "promoteur" não pode exigir nem aceitar pagamento antes da assinatura do contrato correspondente.

construction d'un ou de plusieurs édifices ainsi qu'à procéder elle-même ou à faire procéder, moyennant une rémunération convenue, à tout ou partie des opérations juridiques, administratives et financières concourant au même objet. Ce promoteur est garant de l'exécution des obligations mises à la charge des personnes avec lesquelles il a traité au nom du maître de l'ouvrage. Il est notamment tenu des obligations résultant des articles $1792,1792-1,1792-2$ et $1792-3$ du présent code.

Si le promoteur s'engage à exécuter lui-même partie des opérations du programme, il est tenu, quant à ces opérations, des obligations d'un locateur d'ouvrage.".

${ }^{51}$ Conforme explana Antonio Cilento, L'acquisto di immobili in costruzione tra rischio econômico e tutela della persona, cit., p. 120, e nos termos do art. 11: "La vente prévue à l'article 6 ci-dessus peut être précédée d'un contrat préliminaire par lequel, en contrepartie d'un dépôt de garantie effectué à un compte spécial, le vendeur s'engage à réserver à un acheteur un immeuble ou une partie d'immeuble.

Ce contrat doit comporter les indications essentielles relatives à la consistance de l'immeuble, à la qualité de la construction et aux délais d'exécution des travaux ainsi qu'à la consistance, à la situation et au prix du local réservé.

Les fonds déposés en garantie sont indisponibles, incessibles et insaisissables jusqu'à la conclusion du contrat de vente. Ils sont restitués, dans le délai de trois mois, au déposant si le contrat n'est pas conclu du fait du vendeur ou si le contrat proposé fait apparaître une différence anormale par rapport aux prévisions du contrat préliminaire.

Est nulle toute autre promesse d'achat ou de vente.".

52،Quiconque aura détourné ou dissipé au préjudice des propriétaires, possesseurs ou détenteurs, des effets, deniers, marchandises, billets, quittances ou tous autres écrits contenant ou opérant obligation ou décharge, qui ne lui auraient été remis qu'à titre de louage, de dépôt, de mandat, de nantissement, de prêt à usage, ou pour un travail salarié ou non salarié, à la charge de les rendre ou représenter, ou d'en faire un usage ou un emploi déterminé, sera puni des peines portées en l'article 406.(...)". Referido artigo determina, além de sanções administrativas, pena de prisão e multa. Ressalte-se que a Lei 4.591/64 traz similar previsão, no art. 65 , parágrafo $1^{\circ}$, II, aplicável para construção por administração, definindo que incorre no crime contra a economia popular e sua pena: "II - o incorporador, o corretor e o construtor individuais, bem como os diretores ou gerentes de emprêsa coletiva, incorporadora, corretora ou construtora que usar, ainda que a título de empréstimo, em proveito próprio ou de terceiros, bens ou haveres destinados a incorporação contratada por administração, sem prévia autorização dos interessados.”.

${ }^{53}$ Avant la signature du contrat, le promoteur ne peut exiger ni même accepter du maître de l'ouvrage aucun versement, aucun dépôt, aucune souscription ni acceptation d'effets de commerce. Aucun paiement ne peut non plus être exigé ni accepté avant la date à laquelle la créance est exigible. 
Há limitação percentual para recebimento de valores pelo vendedor, conforme art. R. 261-14 do Code de la construction et de l'habitation, que prevê escalonamento de percentual de valor permitido para pagamento ao incorporador, sendo de $95 \%$ do total do preço, por exemplo, no momento de conclusão da edificação, e os restantes $5 \%$ devidos somente com a imissão na posse. Tal escalonamento representa proteção ao adquirente, por vedar o pagamento antecipado de grande parte ou todo o valor devido.

Ainda, o legislador francês previu, no art. 261-22 do Code de la construction et de l'habitation, a obrigação de o vendedor garantir o reembolso de valores pagos pelo adquirente, em caso de término do contrato por descumprimento da obrigação, sendo o fiador/assegurador da obrigação solidariamente responsável com o vendedor. Ressalte-se a garantia de devolução de valores ao adquirente em caso de término do contrato ${ }^{54}$.

Não obstante a definição, no art. 12 da Lei $n^{\circ} 67^{55}$, de nulidade de qualquer cláusula que contrarie os artigos $8^{\circ}$ ao 11 da norma e os artigos 1.642-1 e 1.646-1do Código Civil, que se referem, respectivamente, à garantia contra vícios aparentes e à garantia contra vícios que afetem solidez da edificação, prevê-se sanção penal em caso de exigência ou aceitação de pagamento em violação aos artigos $8^{\circ}$ ao 11 da lei em questão, sendo de prisão de dois anos e multa de $€ 9.000^{56}$.

Importante aspecto é a definição contida no Code de la construction et de l'habitation quanto à obrigação de resultado do "promoteur" ${ }^{, 57}$ pela entrega da construção, devendo a empresa que garante a obrigação do incorporador reverter valores para que um terceiro finalize as obras ("garantia d'achevement extrinseque"), que é acompanhada da

\footnotetext{
${ }^{54} \mathrm{O}$ art. 10 da lei em questão prevê que o contrato pode prever indenização superior a $10 \%$ do valor pago, sem prejuízo da indenização pelos danos efetivamente causados, em caso de término do contrato: "Le contrat ne peut stipuler forfaitairement, en cas de résolution, le paiement, par la partie à laquelle elle est imputable, d'une indemnité supérieure à 10 p. 100 du prix.

Toutefois, les parties conservent la faculté de demander la réparation du préjudice effectivement subi.”.

${ }^{55}$ Cuja redação é a seguinte: "Toute clause contraire aux dispositions des articles 7 à 11 ci-dessus et à celles des articles 1642-1 et 1646-1 du code civil est réputée non écrite.".

${ }^{56}$ Nos termos do art. 13: "Toute personne qui aura exigé ou accepté un versement en violation des dispositions des articles 8 et 11 de la présente loi sera punie d'un emprisonnement de deux ans et d'une amende de 9000 euros ou de l'une de ces deux peines seulement."

${ }^{57}$ Conforme arts. 1831-4 e 221-4: "La mission du promoteur ne s'achève à la livraison de l'ouvrage que si les comptes de construction ont été définitivement arrêtés entre le maitre de l'ouvrage et le promoteur, le tout sans préjudicier aux actions en responsabilité qui peuvent appartenir au maître de l'ouvrage contre le promoteur."
} 
"garantia d'achevement intrinseque" de que o bem não estará gravado de hipoteca ou outra forma de garantia ${ }^{58}$.

Na Espanha, a venda de imóveis em construção é denominada "compraventa sobre planos" e se caracteriza pela venda de coisa futura, havendo entendimento dos tribunais de que se trata de venda "emptio rei speratae",59.

Ao contrário do ordenamento jurídico brasileiro, o contrato inicial celebrado na Espanha, formalizado mediante instrumento privado, não tem efeito real, produzindo somente efeitos obrigacionais. A transferência de propriedade opera-se somente após entrega da obra, mediante instrumento público, conforme 1.462 do Código Civil ${ }^{60}$.

O assunto específico é tratado na Lei $\mathrm{n}^{\circ} 57 / 68$, que obriga as pessoas que promovem a construção de imóveis e as vendas, mediante cobrança de valores de forma antecipada em relação à finalização da construção ${ }^{61}$.

A lei em comento dispõe que os depósitos feitos pelos adquirentes devem ser realizados em conta vinculada ${ }^{62}$, permitindo-se o uso pelo incorporador tão somente para a construção da edificação, como prevê o legislador francês.

Para garantia de devolução de tais valores ${ }^{63}$, a lei prevê a contratação de seguro obrigatório ou de fiança bancária, que são canceladas assim que expedida a "cédula de

${ }^{58}$ Conforme Lorenzo Mezzasoma, Il "Consumatore" acquirente di immobili da costruire fra diritto al risparmio e diritto all'abitazione, cit., p. 109.

${ }^{59}$ "En ocasiones, el Tribunal Supremo califica este contrato con la modalidad de emptio rei speratae y así en la STS de 22 de marzo de 1993 declara que: "Fueron sendas compraventas de cosa futura (emptio rei speratae), cuya calificación corresponde (SSTS de 17 de febrero de 1967, 3 de junio de 1970, 30 de octubre de 1989) a la de una vivienda o local comercial en proyecto de construcción, que el comprador adquiere exclusivamente en función de su terminación, y en la que el vendedor, una vez que la ha terminado, asume la obligación de entregarla al comprador, que deberá pagar, obviamente, el precio pactado". SOLER PASCUAL, Luis Antonio. Los consumidores ante la adquisición de un bien inmueble en proyecto o en fase de contrucción. Disponível em: $<$ http://revistasocialesyjuridicas.files.wordpress.com/2010/09/03-tm-08.pdf>. Acesso em: 05 dez. 2013.

60،Art. 1462 - Se entenderá entregada la cosa vendida cuando se ponga en poder y posesión del comprador. Cuando se haga la venta mediante escritura pública, el otorgamiento de ésta equivaldrá a la entrega de la cosa objeto del contrato, si de la misma escritura no resultare o se dedujere claramente lo contrario."

${ }^{61}$ Conforme art. $1^{\text {o: }}$ "Las personas físicas y jurídicas que promuevan la construcción de viviendas que no sean de protección oficial, destinadas a domicilio o residencia familiar, con carácter permanente o bien a residencia de temporada, accidental o circunstancial y que pretendan obtener de los cesionarios entregas de dinero antes de iniciar la construcción o durante la misma, deberán cumplir las condiciones siguientes:...)".

${ }^{62}$ Nos termos do parágrafo segundo do art. 1: "Percibir las cantidades anticipadas por los adquirentes a través de una Entidad bancaria o Caja de Ahorros, en las que habrán de depositarse en cuenta especial, con separación de cualquier otra clase de fondos pertenecientes al promotor y de las que únicamente podrá disponer para las atenciones derivadas de la construcción de las viviendas. Para la apertura de estas cuentas o depósitos la Entidad bancaria o Caja de Ahorros, bajo su responsabilidad, exigirá la garantía a que se refiere la condición anterior.".

${ }^{63}$ Conforme parágrafo $2^{\circ}$ do art. $1^{\circ}$ : "Garantizar la devolución de las cantidades entregadas más el seis por ciento de interés anual, mediante contrato de seguro otorgado con Entidad aseguradora inscrita y autorizada 
habitabilidad" e entregue o imóvel ao adquirente, nos termos do art. 4 da lei referida ${ }^{64}$, para garantir a devolução de valores em casos de descumprimento da entrega.

Além das regras aplicáveis a determinadas atividades abrangidas na incorporação imobiliária que se encontram no Código Civil, como as atinentes à responsabilidade do construtor e pela ruína da obra e das constantes a Lei $n^{\circ} 57 / 68$, o legislador previu regras específicas à oferta de imóveis para habitação, nos termos do Real Decreto no 515 de $1989^{65}$.

Prevê tal decreto, em suma, a obrigação de o incorporador disponibilizar as informações atinentes ao empreendimento, inclusive técnicas e as relativas ao condomínio, abrangendo o projeto de construção, as referências a materiais utilizados, data de entrega da obra, preço e forma de pagamento etc.

Fica aquele que violar suas disposições sujeito às sanções previstas no artigo 36 da lei que regula a relação de consumo na Espanha (Lei $\left.n^{\circ} 26 / 84\right)^{66}$, tais como multa, cujo valor varia conforme a gravidade da infração e, no caso de infração muito grave, suspensão temporária de atividades por até cinco anos.

Mais recentemente, a fim de se garantir maior segurança aos adquirentes, foi editada a Lei no 38/99, também denominada "Ley de Ordenación de Edificacion”, ${ }^{\text {, }}$, que

en el Registro de la Subdirección General de Seguros o por aval solidario prestado por Entidad inscrita en el Registro de Bancos y Banqueros, o Caja de Ahorros, para el caso de que la construcción no se inicie o no llegue a buen fin por cualquier causa en el plazo convenido.". Verifique-se que a Lei 38/99, alhures citado, também contem previsão dessa espécie, estipulando, inclusive, multa para o caso de nao devolução dos valores.

${ }^{64}$ Cuja redação é a seguinte: "Expedida la cédula de habitabilidad por la Delegación Provincial del Ministerio de la Vivienda y acreditada por el promotor la entrega de la vivienda al comprador, se cancelerán las garantías otorgadas por la Entidad aseguradora o avalista.".

${ }^{65}$ Referido decreto regula a oferta, promoção e publicidade de venda de habitação para consumidores, complementando a Lei 26 de 84, que se caracteriza como o Código de Defesa do consumidor brasileiro, nos termos do art. 1: "1. El presente Real Decreto es de aplicación a la oferta, promoción y publicidad que se realice para la venta o arrendamiento de viviendas que se efectúe en el marco de una actividad empresarial o profesional, siempre que aquellos actos vayan dirigidos a consumidores, conforme a los términos del artículo primero, apartados 2 y 3, de la Ley 26/1984, de 19 de julio, General para la Defensa de los Consumidores y Usuarios.”..

66“"Artículo trigésimo sexto. 1. Las infracciones en materia de defensa de los consumidores y usuarios serán sancionadas con multas de acuerdo con la siguiente graduación: - Infracciones leves, hasta 500.000 pesetas. - Infracciones graves, hasta 2.500.000 pesetas, pudiendo rebasar dicha cantidad hasta alcanzar el quíntuplo del valor de los productos o servicios objeto de la infracción. - Infracciones muy graves, hasta 100.000.000 de pesetas, pudiendo rebasar dicha cantidad hasta alcanzar el quíntuplo del valor de los productos o servicios objeto de la infracción.

2. En los supuestos de infracciones muy graves, el Consejo de Ministros podrá acordar el cierre temporal del establecimiento, instalación o servicio por un plazo máximo de cinco años. En tal caso, será de aplicación lo prevenido en el artículo 57,4 de la Ley 8/1980, de 10 de marzo, por la que se aprueba el Estatuto de los Trabajadores. (...).”

${ }^{67}$ Conforme se depreende da Exposição de Motivos da lei, que menciona, ademais, que sua finalidade é regular o processo de edificação atualizando e complementando as regras atinentes aos agentes da construção, fixando obrigações e estabelecendo responsabilidades: “(...)Así, la tradicional regulación del suelo contrasta con la falta de una configuración legal de la construcción de los edificios, básicamente 
estipula obrigações do promotor e dos agentes envolvidos na edificação, sendo relevante o fato de ampliar o conceito de "promotor", definindo tal figura como qualquer pessoa que decide, impulsiona, programa e financia obras de edificação, para si ou para futura alienação ou entrega a terceiros ${ }^{68}$.

Há entendimento ${ }^{69}$ de que o promotor age como garantidor das obrigações de terceiros envolvidos no empreendimento, sendo que só se libera da obrigação com a entrega final e adequada do bem, assumindo, assim, obrigação de resultado que só é cumprida mediante entrega da coisa perfeita e acabada.

Ainda, a lei ora tratada define a obrigatoriedade de apresentação de todas as autorizações e licenças, além de estipular critérios de recepção da obra, como a aceitação tácita caso o "promotor" não se manifeste no prazo de trinta dias da data de término das obras ${ }^{70}$.

O cerne da Ley de Ordenación de Edificacion reside no conflito aparente de normas, em razão de haver, em seu bojo, três prazos diferentes de garantia e um prazo prescricional, que parecem ir de encontro às disposições do Código Civil espanhol, no que se refere à garantia contra ruína da edificação, justificando, pois, a análise atenta dos regramentos aplicáveis.

Não obstante a demonstração do cenário geral da venda de imóveis em fase de construção em referidos ordenamentos, determinadas especificidades serão apresentadas em outros tópicos do presente trabalho.

establecida a través del Código Civil y de una variedad de normas cuyo conjunto adolece de serias lagunas en la ordenación del complejo proceso de la edificación, tanto respecto a la identifi- cación, obligaciones y responsabilidades de los agentes que intervienen en el mismo, como en lo que se refiere a las garantías para proteger al usuario... 1. El objetivo prioritario es regular el proceso de la edificación actualizando y completando la configura- ción legal de los agentes que intervienen en el mismo, fijando sus obligaciones para así establecer las respon- sabilidades y cubrir las garantías a los usuarios, en base a una definición de los requisitos básicos que deben satisfacer los edificios." .

${ }^{68}$ Conforme parágrafo $1^{\circ}$ do art. 9 da lei em comento: "1. Será considerado promotor cualquier persona, física o jurídica, pública o privada, que, individual o colectivamente, decide, impulsa, programa y financia, con recursos propios o ajenos, las obras de edificación para sí o para su posterior enajenación, entrega o cesión a terceros bajo cualquier título.”. Referida definição é reflexo de desenvolvimento jurisprudencial, na lição de CERVILLA DOMÍNGUEZ, Miguel. La responsabilidad civil de los agentes de la edificación. Madrid: Ed. Cedro, 2011. p. 25.

${ }^{69}$ CARRASCO PERERA, Ángel; CORDERO LOBATO, Encarna; GONZÁlEZ CARRASCO, Carmen. Derecho de la construcción y la vivienda. 4. ed. Madrid: Editorial Dilex, 2003. p. 391.

${ }^{70}$ Conforme parágrafo $4^{\circ}$ do art. 6: "Salvo pacto expreso en contrario, la recepción de la obra tendrá lugar dentro de los treinta días siguientes a la fecha de su terminación, acreditada en el certificado final de obra, plazo que se contará a partir de la notificación efectuada por escrito al promotor. La recepción se entenderá tácitamente producida si transcurridos treinta días desde la fecha indicada el promotor no hubiera puesto de manifiesto reservas o rechazo motivado por escrito.”. 


\subsection{Definição e classificação}

Determinada a tipificação da incorporação imobiliária no ordenamento jurídico brasileiro e a verificação de sua existência em certos ordenamentos estrangeiros, passa-se à definição de tal atividade ou negócio jurídico.

\subsubsection{Nomenclatura}

A compreensão adequada acerca de um instituto jurídico parte, geralmente, do entendimento quanto à sua nomenclatura.

Incorporação remete à ideia de dar corpo ou forma corpórea a algo ou de união em um só todo ou organização.

Segundo Everaldo Cambler, incorporar indica a ideia de incluir, unir, introduzir ou ligar uma coisa ao corpo da outra ${ }^{71}$.

$\mathrm{Na}$ incorporação imobiliária, agregam-se a um terreno edificações que serão constituídas por unidades autônomas, tal como no condomínio em edificação. Dessa forma, a edificação resultante da construção estará sob o regime de tal condomínio, caracterizado pela conjugação da propriedade exclusiva sobre a unidade autônoma e da propriedade comum, refletida esta em fração-ideal ${ }^{72}$.

\footnotetext{
${ }^{71}$ CAMBLER, Everaldo Augusto. Responsabilidade civil na incorporação imobiliária. São Paulo: Ed. Revista dos Tribunais, 1998. p. 29.

${ }^{72}$ Acerca da fração ideal, convém esclarecer que não havia exigência de sua designação anteriormente à Lei $n^{\circ} 4.591 / 64$, sendo a conceituação da fração ideal uma criação doutrinária. Contudo, trata-se de conceito assaz importante, pois define os direitos e deveres dos condôminos, quanto, por exemplo, à quota-parte devida por cada um deles, o rateio do prêmio do seguro e, em caso de desapropriação, o percentual da indenização correspondente a cada condômino. O Código Civil português, por exemplo, não se refere à fração-ideal, sendo que as despesas de conservação e fruição das partes comuns do edifício são pagas em proporção do valor da unidade, que é fixado com relação ao valor total do prédio, conforme arts. 1.418 e 1.424, respectivamente: "1.No título constitutivo serão especificadas as partes do edifício correspondentes às várias fracções, por forma que estas fiquem devidamente individualizadas, e será fixado o valor relativo de cada fracção, expresso em percentagem ou permilagem, do valor total do prédio." e "1. Salvo disposição em contrário, as despesas necessárias à conservação e fruição das partes comuns do edifício e ao pagamento de serviços de interesse comum são pagas pelos condôminos em proporção do valor das suas fracções.”.
} 
$\mathrm{Na}$ atividade lato sensu, verifica-se a construção de edificação(ões) em terreno, para que deste faça(m) parte, com alienação de unidades autônomas, ou direitos sobre elas, durante a construção.

Ressalte-se que a construção é uma forma artificial de acessão, modo originário de adquirir, pertencendo ao proprietário, em regra, aquilo que se une ou se incorpora ao bem ${ }^{73}$.

Na definição de Luciano Penteado, acessão é "modo de aquisição de propriedade imóvel que é precedido ou acompanhado de uma justaposição física entre bens”, podendo ser de forma natural ou decorrente de atuação do homem ${ }^{74}$.

A regra prevista no art. 1.253 do Código Civil $^{75}$ determina a presunção relativa de que qualquer construção realizada em um terreno é de propriedade do dono do terreno.

Contudo, segundo arts. 1.254 e 1.255 do Código Civil brasileiro ${ }^{76}$, há dever do proprietário de indenizar aquele que construiu com material próprio ou dever de este indenizar aquele, se o que introduziu obra agiu de má-fé. O parágrafo único do art. 1.255 citado $^{77}$, por sua vez, prevê a possibilidade de aquele que introduziu a construção em terreno alheio adquirir propriedade da construção e do terreno, caso aquela seja de valor consideravelmente maior que o valor do terreno.

Não obstante a problemática prática e suas exceções ${ }^{78}$, a regra aponta para o fato de que toda construção é acessão do solo, seja qual for o seu valor.

\footnotetext{
${ }^{73} \mathrm{O}$ Código Civil brasileiro não traz definição de acessão; apenas lista e regula as formas de acessão, no art. 1.248: "A acessão pode dar-se: I - por formação de ilhas; II - por aluvião; III - por avulsão; IV - por abandono de álveo; V - por plantações ou construções.”. O Código Civil português, de outra forma, traz a definição em seu artigo 1.325: "Dá-se a acessão, quando com a coisa que é propriedade de alguém se une e incorpora outra coisa que lhe não pertencia.".

${ }^{74}$ PENTEADO, Luciano de Camargo. Direito das coisas. 2. ed. São Paulo: Ed. Revista dos Tribunais, 2012. p. 343.

75، Art. 1.253. Toda construção ou plantação existente em um terreno presume-se feita pelo proprietário e à sua custa, até que se prove o contrário.”.

76، Art. 1.254. Aquele que semeia, planta ou edifica em terreno próprio com sementes, plantas ou materiais alheios, adquire a propriedade destes; mas fica obrigado a pagar-lhes o valor, além de responder por perdas e danos, se agiu de má-fé." "Art. 1.255. Aquele que semeia, planta ou edifica em terreno alheio perde, em proveito do proprietário, as sementes, plantas e construções; se procedeu de boa-fé, terá direito a indenização."

77، Parágrafo único. Se a construção ou a plantação exceder consideravelmente o valor do terreno, aquele que, de boa-fé, plantou ou edificou, adquirirá a propriedade do solo, mediante pagamento da indenização fixada judicialmente, se não houver acordo.”.

${ }^{78}$ Vale ressaltar que o direito de superfície é exceção à acessão, implicando, nos termos de Melhim Chalhub, "bifurcação do domínio, importando na criação de uma propriedade sobre o solo e outra propriedade sobre a construção ou plantação". CHALHUB, Melhim Namem. Negócio fiduciário. 4. ed. Rio de Janeiro: Renovar, 2009. p. 231.
} 
Desse modo, aquilo que é construído em terreno, em regra, torna-se a ele incorporado, ingressando no campo da propriedade do dono do terreno, cabendo ressaltar o conceito de coisa imóvel do Código Civil, que abrange o solo e aquilo que a ele for incorporado, de forma natural ou artificial ${ }^{79}$.

No tocante à acessoriedade da parte que se acede ou da parte que acede, Darcy Bessone cita que, tendo em vista que a lei não definia a possibilidade de haver acessão do solo à edificação, além de que, se fossem equivalentes os bens, não seria possível identificar qual deles seguiria a sorte do outro, só seria plausível a definição tradicional de que a edificação acede ao solo ${ }^{80}$.

Admissível tal tese, sendo parte principal o solo, sem o qual não se constrói. Há, assim, união e incorporação de edificação segmentada em unidades autônomas a um terreno.

No caso da incorporação imobiliária, o comprador do imóvel adquire direitos previamente à existência efetiva da coisa, que será fruto da acessão pela construção, geralmente mediante aquisição de fração-ideal do terreno ao qual a unidade a ser construída se integrará, formando um todo ${ }^{81}$.

O objeto da incorporação imobiliária como atividade é a comercialização de imóveis a serem construídos, que integrarão edificação que acederá ao solo.

Denota-se, pois, que o bem jurídico adquirido pelos compradores na incorporação imobiliária é futuro, que virá a constituir uma coisa só tão logo se finalize a construção.

Mesmo que a unidade ainda não exista quando da celebração de contrato específico entre incorporador e adquirente, constitui-se, desde aquele momento, direito com eficácia real para os adquirentes ${ }^{82}$, após o registro pertinente, em razão da constituição da propriedade condominial resultante do exercício do direito de construir e da acessão concomitante.

\footnotetext{
${ }^{79}$ Vide art. 79: "São bens imóveis o solo e tudo quanto se lhe incorporar natural ou artificialmente.".

${ }^{80}$ BESSONE, Darcy. Da compra e venda promessa e reserva de domínio. 3. ed. São Paulo: Saraiva, 1988. p. 70.

${ }^{81}$ PINTO, Nelson Luiz Guedes Ferreira. Contrato de incorporação imobiliária, cit., p. 253.

${ }^{82}$ Conforme lição de Everaldo Cambler, em Incorporação imobiliária: ensaio de uma teoria geral, cit., p. 186. Tal lição baseia-se também na redação do parágrafo segundo do art. 32 da Lei 4.591/64, que assim dispõe: “\$ $2^{\underline{o}}$ Os contratos de compra e venda, promessa de venda, cessão ou promessa de cessão de unidades autônomas são irretratáveis e, uma vez registrados, conferem direito real oponível a terceiros, atribuindo direito a adjudicação compulsória perante o incorporador ou a quem o suceder, inclusive na hipótese de insolvência posterior ao término da obra.”.
} 
Tais elementos constitutivos de eficácia de direito real, entre outros, serão analisados ao longo deste trabalho.

\subsubsection{Atividade incorporativa}

A definição legal de incorporação imobiliária está contida no parágrafo único do art. 28 da Lei $n^{\circ} 4.591 / 64$, que assim dispõe:

Art. 28. (...) Parágrafo único. Para efeito desta Lei, considera-se incorporação imobiliária a atividade exercida com o intuito de promover e realizar a construção, para alienação total ou parcial, de edificações ou conjunto de edificações compostas de unidades autônomas. ${ }^{83}$ (grifos da autora)

Referido artigo menciona a incorporação imobiliária como atividade dirigida à promoção de construção de edificações, a serem incorporadas em determinado terreno e devidamente segmentadas em unidades autônomas, e à alienação de tais unidades (ou direitos sobre elas), durante a construção.

O fato de os adquirentes realizarem pagamentos prévios à efetiva transferência do bem futuro é essencial e marca característica da incorporação imobiliária, pois o incorporador obtém recursos para consecução da obra dos próprios adquirentes, o que contribui para a efetividade do empreendimento.

Conforme Caramuru Afonso Francisco, a "incorporação imobiliária foi concebida como uma atividade empresarial mediante a qual se arrecadariam fundos juntos aos adquirentes para a construção de novas unidades imobiliárias" ${ }^{84}$.

Evidentemente, há configuração de atividade a ser desenvolvida pelo incorporador, pessoa que apresenta, comumente, a expertise necessária para assunção de empreendimentos de grande monta e relevância, sendo tal atividade destinada, precipuamente, à venda de unidades autônomas futuras, durante sua construção.

\footnotetext{
${ }^{83}$ Grifos da autora.

${ }^{84}$ FRANCISCO, Caramuru Afonso. O novo regime jurídico dos contratos: das incorporações e do registro imobiliário e da alienação fiduciária em garantia, cit., p. 59.
} 
Desse modo, afirma-se que a incorporação imobiliária decorre de uma atividade, como sequência de atos organizados e voltados à promoção de construção e à alienação de imóveis ainda não concluídos.

Não obstante a indicação legal de que se trata de atividade, é também negócio jurídico pelo qual uma pessoa, física ou jurídica, obriga-se a promover e realizar a construção de edificação dividida em unidades autônomas e a alienar, total ou parcialmente, a edificação e suas unidades autônomas, para constituição posterior do condomínio especial, nos termos da lei.

A tese da existência de duas espécies de incorporação, uma se referindo à atividade e outra ao negócio jurídico, é ratificada por grande parte dos autores ${ }^{85}$.

Para Cambler, a atividade é incorporação lato sensu e a incorporação stricto sensu o negócio jurídico núcleo da atividade incorporativa, por intermédio do qual alguém se obriga a promover a construção do edifício e a transferir a propriedade das unidades autônomas em que esse foi dividido, cabendo à outra parte pagar o preço previamente ajustado $^{86}$.

Segundo Melhim Chalhub ${ }^{87}$, é

(...) atividade empresarial que se caracteriza pela produção e comercialização de imóveis em construção, integrantes de conjuntos imobiliários" e o contrato de incorporação "compreende obrigações de construir e transmitir a propriedade de imóveis integrantes de conjuntos imobiliários, quando celebrado esse negócio jurídico durante a construção.

Luciano Penteado, ainda que defina a incorporação imobiliária como ato jurídico, expõe que, por meio dela, o incorporador institui um projeto de construção de edificação por unidade autônoma "que será objeto de diferentes negócios jurídicos, notadamente de compromissos de compra e venda para terceiros adquirentes, mediante uma oferta pública e indiscriminada $(. . .)^{, 88}$.

\footnotetext{
${ }^{85}$ Nesse sentido, Everaldo Cambler, Melhim Chalhub, Caio Mario da Silva Pereira, entre outros.

${ }^{86}$ CAMBLER, Everaldo Augusto. Incorporação imobiliária: ensaio de uma teoria geral, cit., p. 20.

${ }^{87}$ CHALHUB, Melhim Namem. Alienação fiduciária, incorporação imobiliária e mercado de capitais: estudos e pareceres, cit., p. 241.

${ }^{88}$ PENTEADO, Luciano de Camargo. Direito das coisas, cit., p. 461.
} 
Em razão da dualidade de sua caracterização, cabe, neste momento, avaliar a incorporação imobiliária como negócio jurídico.

\subsubsection{Negócio jurídico}

A incorporação imobiliária, como atividade, não se realiza se não pela agregação de determinados negócios jurídicos, voltados unicamente para a efetividade do empreendimento.

Para que haja cumprimento das principais obrigações do incorporador, no que se refere à completude da incorporação imobiliária e à satisfação dos direitos dos adquirentes, faz-se necessária a formalização de diversos negócios jurídicos, abrangendo prestações características de contratos típicos, como compra e venda, promessa de compra e venda, empreitada, prestação de serviços, bem como outras obrigações que não se verificam em negócios típicos, tal como a constituição do condomínio especial, inerente à incorporação.

De acordo com a lição de Pontes de Miranda ${ }^{89}$,

O negócio jurídico ou série de negócios jurídicos que faz a incorporação é, de regra, negócio jurídico ou série de negócios jurídicos inominados; porém contém necessàriamente promessa, opção, ou compra-e-venda de apartamentos, ou contrato de divisão material e jurídica do bem comum, com discriminação do que é diviso e do que é indiviso. (sic)

Tem-se, assim, um negócio complexo, que envolve diversas prestações.

\subsubsection{Classificação}

O contrato de incorporação pode ser definido como típico, bilateral, sinalagmático $^{90}$, oneroso, comutativo, formal, consensual e de execução diferida.

\footnotetext{
${ }^{89}$ PONTES DE MIRANDA, Francisco Cavalcanti. Tratado de direito predial, cit., v. 2, p. 79.

${ }^{90}$ Orlando Gomes trata os contratos bilaterais como sinalagmáticos, em Contratos. 24. ed. Rio de Janeiro: Forense, 2001. p. 91.
} 
Trata-se de contrato típico ${ }^{91}$, uma vez que a Lei de Incorporação Imobiliária instituiu a incorporação imobiliária e regulou o negócio jurídico correspondente, trazendo, assim, sua tipicidade ao ordenamento jurídico.

É negócio jurídico bilateral, em razão da natureza da obrigação contida em seu bojo, dele derivando obrigações a ambas as partes nos contratos bilaterais, ou seja, as prestações são recíprocas. Aplica-se, portanto, a "exceptio non adimpleti contractus" prevista no art. 476 do Código Civil $^{92}$.

É sinalagmático por gerar obrigações simétricas a uma parte e outra, havendo dependência recíproca das prestações e cumprindo ao incorporador, como contraprestação ao preço pago pelo adquirente, a obrigação de resultado ${ }^{93}$ de entregar a unidade autônoma construída, transferindo-a ao adquirente.

Ressalte-se que o predominante ${ }^{94}$ entendimento de que, em caso de descumprimento de obrigação pelo incorporador, há sua responsabilidade caracterizada, não havendo necessidade de se verificar sua forma de atuação e se ele envidou seus melhores esforços ou empregou todos os meios exigidos, com base no padrão de diligência adotado pelo homem médio, para se atingir determinado resultado.

Rui Stoco menciona que na obrigação de resultado o devedor se obriga a alcançar determinado fim, conseguindo-o ou arcando com as consequências de seu

\footnotetext{
${ }^{91}$ Chalbub entende se tratar de contrato nominado, ainda que tipificado pela lei, conforme CHALHUB, Melhim Namem. Da incorporação imobiliária. 2. ed. Rio de Janeiro: Renovar, 2005. p. 19.

${ }^{92}$ Definido pelo conceito de que nenhum dos contraentes, antes de cumprir sua obrigação, pode exigir o implemento da obrigação do outro contraente, conforme redação do artigo: “Art. 476. Nos contratos bilaterais, nenhum dos contratantes, antes de cumprida a sua obrigação, pode exigir o implemento da do outro.”.

${ }^{93} \mathrm{Na}$ lição de Orlando Gomes, Contratos, cit., 26. ed., 2008, p. 554.

${ }^{94}$ Melhim Chalhub, por exemplo, menciona a obrigação do incorporador como de resultado, justificando sua responsabilidade objetiva em caso de inexecução da incorporação, e estabelece que o incorporador deve indenizar os adquirentes dos prejuízos que a estes advierem do fato de não se concluir a edificação ou de se retardar injustificadamente a conclusão da obra (CHALHUB, Melhim Namem. Alienação fiduciária, incorporação imobiliária e mercado de capitais: estudos e pareceres, cit., p. 246). Segundo Orlando Gomes, "Considerado conforme seus efeitos, a obrigação do incorporador é de resultado, eis que se compromete a entregar à outra parte a sala, o apartamento, a loja ou qualquer outra unidade autônoma que se obrigou a construir, cumprindo-lhe, em caso de inexecução, justificá-la, sob pena de pagar perdas e danos" (Contratos, cit., 26. ed., p. 553). Everaldo Cambler menciona que a obrigação do incorporador é de resultado, sendo a essência da prestação o bem jurídico almejado. Configura-se o descumprimento da "obrigação de resultado pela simples inocorrência concreta do resultado certo e determinado, restando presumida a responsabilidade, de sorte que, inadimplida a obrigação, o devedor fica obrigado a reparar o dano." (CAMBLER, Everaldo Augusto. Responsabilidade civil na incorporação imobiliária, cit., p. 63).
} 
descumprimento, usando de exemplo o contrato de empreitada, enquanto na obrigação de meio a finalidade é a atividade do devedor e não seu resultado ${ }^{95}$.

O incorporador não garante que envidará esforços para atingir a finalidade da incorporação, garantindo, sim, que tal finalidade será obtida, ou seja, a construção será finalizada, com individualização das unidades autônomas e entrega destas, nas condições contratadas, aos respectivos adquirentes.

Tal distinção mostra-se assaz relevante no que toca à definição da responsabilidade do incorporador, o que será analisado em capítulo específico.

É certo que se trata de contrato oneroso, pois implica vantagens e prestações para ambas as partes, sendo comutativo, em contraposição ao aleatório, por haver certeza em relação às prestações e às vantagens das partes.

É formal, tendo em vista que se exige a forma escrita, ainda que não haja exigência estrita de escritura pública ${ }^{96}$.

Trata-se de contrato consensual ${ }^{97}$, por não haver transferência ou entrega da coisa no momento do negócio, ainda que se possa afirmar que há constituição de direito com eficácia real para os adquirentes da unidade, após o registro pertinente, como mencionado alhures ${ }^{98}$.

A formação do negócio jurídico incorporativo merece destaque.

O incorporador, com observância da lei, anuncia publicamente determinado empreendimento, podendo haver aceitação da oferta pelo adquirente, vinculando, assim, o incorporador.

Nesse sentido, conforme explana Everaldo Cambler, há obrigação de aceitação, pelo incorporador, de proposta feita pelo interessado, o que coloca aquele na posição de

\footnotetext{
${ }^{95}$ STOCO, Rui. Tratado de responsabilidade civil: doutrina e jurisprudência. 8. ed. São Paulo: Ed. Revista dos Tribunais, 2011. p. 199.

${ }^{96}$ Chalhub menciona ser solene, porque sua validade depende da observância da forma prescrita em lei e do cumprimento de diversos requisitos, inclusive quanto ao registro da incorporação e dos contratos a ela referentes no Cartório de Registro de Imóveis. CHALHUB, Melhim Namem. Da incorporação imobiliária, cit., p. 145.

${ }^{97} \mathrm{O}$ contrato consensual (como, por exemplo, o compromisso de compra e venda) torna-se perfeito e acabado no momento em que nasce o vínculo entre as partes. Para sua formação, são necessárias duas ou mais declarações de vontade que se encontrem emitidas por duas ou mais partes, ou a atuação do oblato.

${ }^{98}$ Ressalte-se que a exigência de registro do contrato preliminar, conforme parágrafo único do art. 463 do Código Civil, refere-se à produção de efeitos perante terceiros.
} 
“oblato" e este na posição de "policitante", em razão da divulgação pública do negócio realizada pelo incorporador, sendo, pois, uma oferta pública ${ }^{99}$.

De qualquer maneira, forma-se o contrato com a oferta e aceitação, desde que não haja retratação permitida em lei pelo incorporador, no período de carência, a ser oportunamente tratado.

Há, desde logo, eficácia do negócio, sendo que a obrigação posterior de celebrar contratos relativos à fração ideal e à construção e de instituir o condomínio pode ser entendida como ratificação do contrato concluído com adesão a proposta.

$\mathrm{Na}$ incorporação imobiliária, o contrato relativo à fração ideal ou a outro direito do adquirente segue padrões e há, inclusive, uniformização de cláusulas, o que determina a prática da celebração desses contratos por meio de formulários impressos.

Pela necessidade e prática de generalização das condições para todos os adquirentes e pela determinação legal, é possível afirmar que os contratos são aceitos pelos adquirentes $^{100}$, ainda que algum poder de negociação de cláusulas lhes reste ${ }^{101}$, havendo, assim, caráter de adesividade nos negócios jurídicos da incorporação imobiliária.

Tal caráter influi na interpretação de contratos, tendo o Código Civil, em seus arts. $423^{102}$ e $424^{103}$, definido, além da nulidade de cláusulas que estipulem renúncia a direitos pelo aderente, que cláusulas ambíguas ou contraditórias serão interpretadas de forma favorável ao aderente.

Há entendimentos de que referido contrato é de execução continuada ou sucessiva $^{104}$.

\footnotetext{
${ }^{99}$ CAMBLER, Everaldo Augusto. Responsabilidade civil na incorporação imobiliária, cit., p. 198.

${ }^{100}$ Os contratos podem ser paritários e por adesão, havendo, ainda, discussão acerca dos contratos por adesão e de adesão, o que não será, contudo, avaliado neste trabalho.

${ }^{101}$ O parágrafo primeiro do art. 54 do Código de Defesa do Consumidor dispõe que a "inserção de cláusula no formulário não desfigura a natureza de adesão do contrato". Desse modo, ainda que haja alguma negociação e/ou alteração em relação ao contrato, podemos afirmar que os contratos são padronizados pelas incorporadoras e aderidos pelos adquirentes.

102““Art. 423. Quando houver no contrato de adesão cláusulas ambíguas ou contraditórias, dever-se-á adotar a interpretação mais favorável ao aderente."

103، “Art. 424. Nos contratos de adesão, são nulas as cláusulas que estipulem a renúncia antecipada do aderente a direito resultante da natureza do negócio.”. Deve-se ressaltar, oportunamente, que não só os contratos de adesão contêm cláusulas abusivas. No âmbito do Código de Defesa do Consumidor, as cláusulas abusivas são tratadas em artigos segregados daqueles que definem o contrato de adesão.

${ }^{104}$ CHALHUB, Melhim Namem. Alienação fiduciária, incorporação imobiliária e mercado de capitais: estudos e pareceres, cit., p. 241 e 323. E GOMES, Orlando. Contratos, cit., 26. ed., 2008, p. 553.
} 
No entanto, a obrigação, na incorporação imobiliária, é voltada a uma prestação praticamente única, qual seja, a entrega de unidade autônoma em edificação devidamente construída e transferência de sua propriedade ao adquirente.

Sendo assim, ainda que seja um contrato que perdura no tempo, mediante atividades preparatórias distintas até a consecução de sua finalidade, não se pode afirmar haver execução continuada ou sucessiva, havendo, sim, uma obrigação que é diferida no tempo.

Tal contrato pode ser caracterizado como contrato coligado, considerando-se que abrange diversas atividades e atos jurídicos e engloba objetos típicos ou atípicos, com um propósito único: a criação de unidades imobiliárias individualizadas em edificação e sua posterior transferência aos respectivos adquirentes.

Francisco Marino define, como primeiro elemento característico da coligação contratual, a pluralidade de contratos e, como segundo, o vínculo funcional entre os contratos, caracterizado este pela existência de um resultado econômico-social determinado ${ }^{105}$.

É certo que na incorporação imobiliária há vínculo entre todos os contratos celebrados, com uma pluralidade de partes, sendo que todos estão voltados à finalidade da incorporação, ou seja, à entrega das unidades autônomas devidamente acabadas a todos os adquirentes.

Chalhub entende que

De fato, embora cada venda, ou promessa de venda, de unidade imobiliária (na qual esta embutida a atividade de construção) dê origem a uma relação jurídica individual, sua execução extravasa o limite da individualidade dos contratantes, vinculando-os indissoluvelmente por um fim comum que constitui o ponto de conjunção de todos os contratos de venda $(. . .)^{106}$.

Nesse sentido, os contratos de construção, financiamento, de promessa ou compra e venda, de alienação fiduciária em garantia, conforme o caso, estão intrinsicamente ligados, embora autônomos.

\footnotetext{
${ }^{105}$ MARINO, Francisco Paulo de Crescenzo. Contratos coligados no direito brasileiro. São Paulo: Saraiva, 2009. p. 127 e 132.

${ }^{106}$ CHALHUB, Melhim Namem. Alienação fiduciária, incorporação imobiliária e mercado de capitais: estudos e pareceres, cit., p. 304.
} 
Considerando que, na coligação de contratos com partes distintas, o inadimplemento de um dos figurantes pode afetar os demais ${ }^{107}$, reforça-se a afirmação de que o cumprimento de obrigações em um contrato coligado é essencial à sobrevivência da coligação.

Verifica-se que o cumprimento das obrigações pelos adquirente e pelo próprio incorporador afeta o empreendimento como um todo, havendo reflexo do inadimplemento de uma das partes em determinado contrato nos demais contratos relacionados, em virtude da unidade finalística existente entre eles.

Por essa razão, afirma-se que a expectativa e a necessidade, na incorporação, é que todos os envolvidos cumpram adequadamente suas obrigações, de forma a assegurar a consecução de seu objetivo.

\subsubsection{Partes}

A incorporação imobiliária pode envolver diversos atores, não apenas o incorporador e o adquirente.

Por se tratar de um negócio extremamente complexo, outras figuras podem atuar de forma essencial para a consecução da finalidade maior da incorporação imobiliária.

Podemos citar, exemplificativamente, o construtor, quando este não for $o$ incorporador, o arquiteto, o financiador da obra ou da aquisição de unidades pelos adquirentes, o proprietário do terreno em que se for construir, se não for o próprio incorporador, entre outros sujeitos que se envolvam no empreendimento.

Não obstante, identificar-se-ão as duas principais partes do contrato: o incorporador e o adquirente.

\footnotetext{
${ }^{107}$ Conforme MARINO, Francisco Paulo de Crescenzo. Contratos coligados no direito brasileiro, cit., p. 205. Ruy Rosado, por sua vez, entende que a resolução de um contrato só atuará sobre o outro se um for acessório ao outro ou no caso de se demonstrar a impossibilidade de sobrevivência de um sem o outro, por se afetar o interesse que o credor poderia ter no outro. AGUIAR JÚNIOR, Ruy Rosado de. Extinção dos contratos por incumprimento do devedor: Resolução - de acordo com o novo Código Civil. 2. ed. Rio de Janeiro: Aide Ed., 2003. p. 90.
} 


\subsection{Incorporador}

O nome do incorporador deve ser indicado de forma ostensiva no local da construção, determinando a lei a obrigatoriedade de definição do incorporador ${ }^{108}$.

O incorporador pode ser pessoa física ou jurídica. Contudo, pela especialização da atividade, é corriqueira a caracterização do incorporador como pessoa jurídica, podendo haver, inclusive, criação de empresa de propósito específico para tal atividade.

O art. 29 da Lei de Incorporação ${ }^{109}$ define o incorporador como a pessoa, comerciante ou não, que compromissa ou efetiva venda de frações ideais de um terreno para sua vinculação a unidades autônomas futuras, ainda que não efeue diretamente a construção.

Tendo o Código Civil de 2002 abarcado a teoria da atividade empresarial, não se faz distinção entre o incorporador "comerciante ou não", bastando que este atue de forma organizada na venda de unidades autônomas em construção.

A própria Lei $n^{\circ} 4.591 / 64$ indica que, independentemente de organização da atividade, será estendida a condição de incorporador àquele que aja como incorporador, contratando a construção de edifícios que se destinem a constituição de condomínios e alienando direitos antes de finalizada a obra ${ }^{110}$.

$\mathrm{O}$ incorporador age como um empreendedor, atraindo e administrando recursos financeiros voltados à realização da incorporação.

\footnotetext{
${ }^{108}$ Conforme PEREIRA, Caio Mário da Silva. Condomínio e incorporações, cit., p. 255, com base no art. 31, parágrafo $2^{\circ}$ da lei: "§ $2^{\circ}$ Nenhuma incorporação poderá ser proposta à venda sem a indicação expressa do incorporador, devendo também seu nome permanecer indicado ostensivamente no local da construção.”.

109، Art. 29. Considera-se incorporador a pessoa física ou jurídica, comerciante ou não, que embora não efetuando a construção, compromisse ou efetive a venda de frações ideais de terreno objetivando a vinculação de tais frações a unidades autônomas, (VETADO) em edificações a serem construídas ou em construção sob regime condominial, ou que meramente aceite propostas para efetivação de tais transações, coordenando e levando a termo a incorporação e responsabilizando-se, conforme o caso, pela entrega, a certo prazo, preço e determinadas condições, das obras concluídas."

${ }^{110}$ Conforme redação do art. 30 da lei em questão: "Art. 30. Estende-se a condição de incorporador aos proprietários e titulares de direitos aquisitivos que contratem a construção de edifícios que se destinem a constituição em condomínio, sempre que iniciarem as alienações antes da conclusão das obras.". Nesse sentido, irretocável decisão do STJ, no REsp n⿳ 1.065.132 - RS, Quarta Turma, Rel. Min. Luis Felipe Salomão, julg. em 06.06.13, excluindo a solidariedade dos donos do terreno que foi objeto de permuta, em razão de paralisação das obras: “(...) Ainda que a Lei de Incorporações equipare o proprietário ao incorporador, não o faz incondicionalmente, porquanto vincula aquele à prática de alguma atividadecondizente com a relação jurídica incorporativa, como no art. 30, por exemplo, em que se prevê a contratação da construção de edifícios destinados à constituição em condomínio: (...)”.
} 
De acordo com o previsto na lei em questão, o incorporador, sendo aquele que inicia e se responsabiliza pela incorporação, pode ser o proprietário do terreno em que se pretenda construir a edificação, o promitente comprador do terreno ou aquele que possua outros direitos que o permitam realizar a construção sobre referido terreno (como o cessionário ou promitente cessionário), bem como o construtor ou o corretor de imóveis, ou, hipótese menos aventada e pouco relevante para o presente trabalho, o ente da Federação imitido na posse a partir de decisão proferida em processo judicial de desapropriação em curso ou o cessionário deste, conforme comprovado mediante registro no Cartório de Registro de Imóveis competente ${ }^{111}$.

Os requisitos impostos pela lei, no que se refere a quem pode ser o incorporador, justificam-se pela capacidade e legitimidade de tal figura, uma vez que a finalidade da incorporação não se alcançaria se aquele que efetiva a venda das unidades ou alienação dos direitos a serem adquiridos pelos compradores não tivesse poderes para tanto.

Por esse motivo, é exigível que o incorporador tenha direitos sobre o terreno no qual se assentará a edificação e/ou poderes para promover a construção ou alienação dos direitos, respectivamente em relação ao construtor e ao corretor, assegurando o parágrafo primeiro do art. 31 da lei ${ }^{112}$ que, no caso do inciso "b" do artigo em questão, deve haver mandato contendo todos os requisitos legais, outorgado pelo proprietário de terreno, o promitente comprador e cessionário ou promitente cessionário deste, para que se permita a atuação do mandatário.

\subsection{Adquirente}

De outro lado, pode ser parte em tal contrato qualquer pessoa, física ou jurídica, que se proponha a adquirir uma ou mais unidades autônomas constituintes da edificação a ser construída, observadas as condições de capacidade estabelecidas no Código Civil.

\footnotetext{
${ }^{111}$ Nos termos do art. 31 da lei: "Art. 31. A iniciativa e a responsabilidade das incorporações imobiliárias caberão ao incorporador, que somente poderá ser: a) o proprietário do terreno, o promitente comprador, o cessionário deste ou promitente cessionário com título que satisfaça os requisitos da alínea a do art. 32; b) o construtor ou corretor de imóveis; c) o ente da Federação imitido na posse a partir de decisão proferida em processo judicial de desapropriação em curso ou o cessionário deste, conforme comprovado mediante registro no registro de imóveis competente.".

112“Art. 31. § $1^{\circ}$ No caso da alínea b, o incorporador será investido, pelo proprietário de terreno, o promitente comprador e cessionário deste ou o promitente cessionário, de mandato outorgado por instrumento público, onde se faça menção expressa desta Lei e se transcreva o disposto no $\S 4^{\circ}$, do art. 35, para concluir todos os negócios tendentes à alienação das frações ideais de terreno, mas se obrigará pessoalmente pelos atos que praticar na qualidade de incorporador."
} 
O adquirente é parte fundamental da incorporação, tendo em vista que sem seu interesse e participação, com cumprimento rigoroso de suas obrigações, o empreendimento não tem sucesso.

Ainda que não se trate de fato de parte do negócio jurídico da incorporação, cabe ressaltar importantes formas de representação dos adquirentes, criadas pela Lei $\mathrm{n}^{\circ}$ 4.591/64 no sentido de assegurar maior proteção a esses.

\subsection{Representação dos adquirentes - Comissão de Representantes e Assembleia}

Um dos elementos essenciais ao contrato de incorporação é a Comissão de Representantes, constituída para fiscalizar as obras, entre outras atribuições ${ }^{113}$.

Segundo o art. 50 da Lei ${ }^{\circ} 4.591 / 64^{114}$, a Comissão de Representantes, composta de três membros, pelo menos, escolhidos entre os adquirentes, será eleita em assembleia ou indicada no contrato de construção.

A Comissão de Representantes atua perante o construtor ou perante o incorporador, no caso do art. 43, sempre com vistas a garantir o bom andamento do empreendimento.

Referida Comissão recebe plenos poderes para exercer todas as atribuições e praticar todos os atos que a lei em questão e o contrato de construção lhe deferem, sem que haja necessidade de formalização de instrumento de mandato ${ }^{115}$.

Tendo em vista que os seus membros podem ser designados no contrato pelo incorporador, há críticas ${ }^{116}$ pertinentes acerca da possibilidade de indicação, para constituir a

\footnotetext{
${ }^{113}$ Caio Mario assim define aludida Comissão: “(...) é o órgão de controle do desenvolvimento da incorporação e da construção...". Condomínio e incorporações, cit., p. 258.

114،A Art. 50. Será designada no contrato de construção ou eleita em assembléia geral uma Comissão de Representantes composta de três membros, pelo menos, escolhidos entre os adquirentes, para representá-los perante o construtor ou, no caso do art. 43, ao incorporador, em tudo o que interessar ao bom andamento da incorporação, e, em especial, perante terceiros, para praticar os atos resultantes da aplicação dos arts. 31-A a 31-F."

${ }^{115}$ Segundo a regra do parágrafo $1^{\circ}$ do art. 50 da Lei de Incorporação: "§ $1^{\circ}$ Uma vez eleita a Comissão, cuja constituição se comprovará com a ata da assembléia, devidamente inscrita no Registro de Títulos e Documentos, esta ficará de pleno direito investida dos poderes necessários para exercer todas as atribuições e praticar todos os atos que esta Lei e o contrato de construção lhe deferirem, sem necessidade de instrumento especial outorgado pelos contratantes ou se for caso, pelos que se sub-rogarem nos direitos e obrigações destes."

${ }^{116}$ Como CHALHUB, Melhim Namem. Alienação fiduciária, incorporação imobiliária e mercado de capitais: estudos e pareceres, cit., p. 307.
} 
Comissão, de pessoas ligadas ao incorporador, uma vez que essa vinculação pode prejudicar os futuros adquirentes, que não terão, em tese, representação legítima de seus interesses.

Apesar das críticas, o parágrafo $2^{\circ}$ do art. 50 antes referido permite que a Assembleia altere, por maioria absoluta, a composição da Comissão, de forma que os membros indicados pelo incorporador possam ser integralmente substituídos por pessoas ligadas de fato aos adquirentes.

Deve-se ter em mente que o papel da Comissão é essencial ao êxito do empreendimento, pois a ela cabe adotar as providências necessárias para o bom andamento da obra, alterar a programação da obra ${ }^{117}$, conforme relatórios periódicos entregues pelo incorporador, verificar o patrimônio de afetação ${ }^{118}$, quando instituído pelo incorporador, entre outras responsabilidades relacionadas à fiscalização e à administração das obras.

Ainda que sua importância seja geral, independentemente da modalidade de incorporação, podemos afirmar que sua atuação deve ser muito mais focada na hipótese da modalidade de incorporação por administração ${ }^{119}$, que enseja maiores riscos aos adquirentes, por serem estes responsáveis integralmente pelo pagamento do custo integral da obra, inclusive materiais e tributos, podendo ser caracterizados como os reais donos da obra.

\footnotetext{
${ }^{117}$ Conforme se depreende possível da análise da parte final do art. 31-D, IV, da Lei de Incorporação, que faz ressalva a modificações sugeridas pelo incorporador e aprovadas pela Comissão de Representantes: “ IV entregar à Comissão de Representantes, no mínimo a cada três meses, demonstrativo do estado da obra e de sua correspondência com o prazo pactuado ou com os recursos financeiros que integrem o patrimônio de afetação recebidos no período, firmados por profissionais habilitados, ressalvadas eventuais modificações sugeridas pelo incorporador e aprovadas pela Comissão de Representante.”.

${ }^{118}$ É de se ressaltar que a Lei $n^{\circ} 10.931 / 04$, entre outras definições, trouxe a instituição do patrimônio de afetação e incluiu diversas referências à Comissão de Representantes, dando maior poder de fiscalização e acompanhamento das obras aos adquirentes, bem como amplo poder na hipótese de insolvência ou falência do incorporador.

${ }^{119}$ Veja-se previsão do art. 61 da lei, aplicável a construções por administração: “Art. 61. A Comissão de Representantes terá poderes para, em nome de todos os contratantes e na forma prevista no contrato: a) examinar os balancetes organizados pelos construtores, dos recebimentos e despesas do condomínio dos contratantes, aprová-los ou impugná-los, examinando a documentação respectiva; b) fiscalizar concorrências relativas às compras dos materiais necessários à obra ou aos serviços a ela pertinentes; c) contratar, em nome do condomínio, com qualquer condômino, modificações por êle solicitadas em sua respectiva unidade, a serem administradas pelo construtor, desde que não prejudiquem unidade de outro condômino e não estejam em desacôrdo com o parecer técnico do construtor; d) fiscalizar a arrecadação das contribuições destinadas à construção; e) exercer as demais obrigações inerentes a sua função representativa dos contratantes e fiscalizadora da construção e praticar todos os atos necessários ao funcionamento regular do condomínio."
} 
Nessa modalidade, os adquirentes têm apenas estimativa inicial do custo, que é revista pelo menos semestralmente, de forma conjunta pela Comissão de Representantes e pelo construtor, conforme art. 60 da lei em questão ${ }^{120}$.

Segundo Nelson Luiz Guedes Ferreira Pinto, qualquer deliberação que ultrapassar os poderes da Comissão, definidos na lei ou contrato, não obriga os adquirentes ${ }^{121}$.

Os amplos direitos outorgados à Comissão devem ser exercidos nos exatos limites da outorga ${ }^{122}$, podendo a Assembleia Geral dos adquirentes, com base no art. 50, parágrafo $2^{\circ}$, revogar o mandato de seus membros ou qualquer de suas decisões.

Tal revogação depende de decisão de maioria absoluta dos votos dos adquirentes e se excetua em relação a direitos de terceiros quanto a efeitos já produzidos.

Segundo Franco e Gondo, uma vez constituída, a Comissão de Representantes perdura até o término das obras, salvo no caso acima mencionado de destituição ou se o contrato limitar-lhe a duração, em casos de renúncia, morte, interdição, ou qualquer fato hábil a incompatibilizar qualquer um de seus membros com o bom cumprimento de suas funções $^{123}$. A lei, ainda, traz outra possibilidade relativa ao mandato, que não se refere ao término, mas a uma forma de substituição de membro da Comissão em caso de subrogação do próprio contrato de construção por terceiro ${ }^{124}$.

Ressalte-se que, como a Comissão de Representantes age como mandatária e tem poderes, por exemplo, para efetuar leilão para venda, promessa de venda ou de cessão, ou a

\footnotetext{
120“'Art. 60 - As revisões da estimativa de custo da obra serão efetuadas, pelo menos semestralmente, em comum entre a Comissão de Representantes e o construtor. O contrato poderá estipular que, em função das necessidades da obra sejam alteráveis os esquemas de contribuições quanto ao total, ao número, ao valor e à distribuição no tempo das prestações. Parágrafo único. Em caso de majoração de prestações, o nôvo esquema deverá ser comunicado aos contratantes, com antecedência mínima de 45 dias da data em que deverão ser efetuados os depósitos das primeiras prestações alteradas.".

${ }^{121}$ PINTO, Nelson Luiz Guedes Ferreira. Contrato de incorporação imobiliária. In: THEODORO JUNIOR, Humberto (Coord.). O contrato imobiliário e a legislação tutelar do consumo. Rio de Janeiro: Forense, 2002. p. 271.

${ }^{122}$ Conforme o art. 116 do Código Civil, o representante deve limitar-se aos poderes que lhe forem outorgados. No caso da Comissão, os poderes outorgados aos seus membros estão restritivamente definidos pela própria lei e eventualmente pelo contrato de construção. Além disso, a lei prevê, em seu art. 31-F, parágrafo $9^{\circ}$, semelhante previsão: "A Comissão de Representantes cumprirá o mandato nos termos e nos limites estabelecidos pela deliberação da assembléia geral e prestará contas aos adquirentes, entregando-lhes o produto líquido da alienação, no prazo de cinco dias da data em que tiver recebido o preço ou cada parcela do preço.”.

${ }^{123}$ FRANCO, João Nascimento; GONDO Nisske. Incorporações imobiliárias, cit., p. 160.

${ }^{124}$ Esse é o entendimento quanto à parte final do parágrafo $3^{\circ}$ do art. 50 da lei, que assim dispõe: "§ $3^{\circ}$ Respeitados os limites constantes desta Lei, o contrato poderá discriminar as atribuições da Comissão e deverá dispor sôbre os mandatos de seus membros, sua destituição e a forma de preenchimento das vagas eventuais, sendo lícita a estipulação de que o mandato conferido a qualquer membro, no caso de sub-rogação de seu contrato a terceiros, se tenha por transferido, de pleno direito, ao sub-rogatário, salvo se êste não o aceitar.”.
} 
cessão da quota de terreno e correspondente parte construída e direitos a ela atinentes ${ }^{125}$, nas hipóteses em que ela atua, não deve haver incidência do Código de Defesa do Consumidor, $^{126}$ pois a Comissão representa os adquirentes, não havendo, pois, caracterização de relação de consumo.

No tocante à Assembleia, esta tem função precípua de deliberar sobre assuntos de relevância geral no que se refere à construção, nos termos do art. 49 da Lei no 4.591/64 ${ }^{127}$.

Sua atuação é prevista em qualquer modalidade de contratação, mas sua participação é muito mais relevante nos casos em que não há contratação da entrega da unidade a prazo e preços certos, conforme art. 43 da Lei no 4.591/64.

A Assembleia pode ser convocada, para tratar de assuntos importantes, por um terço dos votos dos adquirentes, pelo próprio incorporador ou pelo construtor, devendo-se observar os requisitos de antecedência e forma de convocação, bem como os relacionados à indicação específica dos assuntos a serem tratados.

A Assembleia é, como no condomínio especial, o conjunto dos adquirentesproprietários, sendo sua decisão, portanto, a mais pura representação de seus interesses.

Como já visto, a Assembleia tem poderes sobre a composição da Comissão de Representantes, além de outros expressos na lei, como em relação à decisão de prosseguimento ou não nas obras em caso de insolvência ou falência do incorporador, nos termos dos artigos 31-A a 31-F e do artigo 43, VII, à decisão de exercício da preferência na aquisição de imóveis que vão a leilão em caso de falta de pagamento por determinado

\footnotetext{
${ }^{125}$ Conforme art. 63, parágrafo primeiro da Lei n $\mathrm{n}^{\text {0 }}$.591/64: "É lícito estipular no contrato, sem prejuízo de outras sanções, que a falta de pagamento, por parte do adquirente ou contratante, de 3 prestações do preço da construção, quer estabelecidas inicialmente, quer alteradas ou criadas posteriormente, quando fôr o caso, depois de prévia notificação com o prazo de 10 dias para purgação da mora, implique na rescisão do contrato, conforme nele se fixar, ou que, na falta de pagamento, pelo débito respondem os direitos à respectiva fração ideal de terreno e à parte construída adicionada, na forma abaixo estabelecida, se outra forma não fixar o contrato. $\S 1^{\circ}$ Se o débito não for liquidado no prazo de 10 dias, após solicitação da Comissão de Representantes, esta ficará, desde logo, de pleno direito, autorizada a efetuar, no prazo que fixar, em público leilão anunciado pela forma que o contrato previr, a venda, promessa de venda ou de cessão, ou a cessão da quota de terreno e correspondente parte construída e direitos, bem como a subrogação do contrato de construção.”. Tal procedimento específico da incorporação imobiliária é considerando, segundo Caio Mario, como opção legislativa justa, por ser rápido e assegurar tanto o interesse dos demais adquirentes, ao se estabelecer a reversão aocondomínio do preço apurado na venda forçada com as deduções previstas, quanto o do próprio adquirente inadimplente, já que este pode receber eventual saldo. PEREIRA, Caio Mário da Silva. Código de Defesa do Consumidor e as incorporações imobiliárias. Revista dos Tribunais, São Paulo, v. 84, n. 712, p. 102-111, fev. 1995.

${ }^{126}$ CAMBLER, Everaldo Augusto. Responsabilidade civil na incorporação imobiliária, cit., p. 306.

127،Art. 49. Os contratantes da construção, inclusive no caso do art. 43, para tratar de seus interêsses, com relação a ela, poderão reunir-se em assembléia, cujas deliberações, desde que aprovadas por maioria simples dos votos presentes, serão válidas e obrigatórias para todos êles salvo no que afetar ao direito de propriedade previsto na legislação.".
} 
adquirente, conforme art. 63, parágrafo terceiro ${ }^{128}$, e, o que muito interessa ao presente trabalho, à hipótese de destituição do incorporador, em caso de retardamento injustificado da obra, nos termos do art. 43, VI, da Lei nº 4.591/64.

Ressalte-se que o direito de um adquirente participar na Assembleia depende do cumprimento de suas obrigações, devendo-se sempre verificar se os adquirentes, em Assembleia, estão adequadamente exercendo as atividades que lhes incumbem, ressaltando-se que qualquer decisão que afete o direito de propriedade dos adquirentes depende do voto da unanimidade.

Sendo mencionadas, de forma sumária, algumas das atribuições das duas formas de atuação no empreendimento, por parte dos adquirentes, passemos à análise do objeto do negócio jurídico da incorporação imobiliária.

\subsubsection{Objeto}

O objeto do contrato de incorporação, segundo Orlando Gomes, é a venda de unidade autônoma em edifício construído em regime de condomínio especial, por pessoa habilitada a promover sua construção ${ }^{129}$.

Conforme demonstrado, há um plexo de contratos para satisfação do objetivo da incorporação imobiliária, que envolve a alienação de direitos sobre unidades autônomas futuras, a promoção da construção e a existência da propriedade condominial futura.

Dessa forma, a incorporação imobiliária, como negócio jurídico, abrange a alienação prévia de direitos sobre a coisa futura, a construção da edificação a ser dividida em partes privadas e partes comuns, a consequente constituição do condomínio especial em tal edificação e a efetiva transferência da propriedade do imóvel devidamente construído ao adquirente ${ }^{130}$.

Referido contrato abrange, ainda, outras atividades necessárias para a consecução do objetivo da incorporação imobiliária, bem como o conteúdo das normas dispostas na Lei $\mathrm{n}^{\circ} 4.591 / 64$, que completa o contrato de incorporação imobiliária.

\footnotetext{
128، $§ 3^{\circ}$ No prazo de 24 horas após a realização do leilão final, o condomínio, por decisão unânime de Assembléia-Geral em condições de igualdade com terceiros, terá preferência na aquisição dos bens, caso em que serão adjudicados ao condomínio.".

${ }^{129}$ GOMES, Orlando. Contratos, cit., 26. ed., 2008, p. 552.

${ }^{130}$ Nesse sentido, Orlando Gomes informa "não se admitir o domínio da unidade construída sem se ser condômino do terreno", sendo nulo o contrato de incorporação sem um desses direitos reais (Contratos, cit., 26. ed., 2007, p. 551). Tal afirmação é condizente com o fato de haver união intrínseca entre a edificação e o terreno, em razão da acessão.
} 
Considerando o objetivo da incorporação imobiliária e da celebração do negócio jurídico correspondente, entende-se que as obrigações do incorporador abrangem a promoção da construção e a transferência da propriedade da unidade autônoma alienada, sendo que tais obrigações envolvem diversas prestações, mas sempre se referindo às obrigações de fazer (promover a construção) ${ }^{131}$ e às de dar (transferir a unidade).

A promoção da construção, a ser desenvolvida mediante consecução de diversas atividades e obrigações específicas enseja, de fato, a obrigação de fazer. Contudo, a finalidade precípua do negócio jurídico em questão é a entrega do imóvel pronto e acabado, de acordo com o detalhamento da respectiva incorporação imobiliária. Nesse sentido, a obrigação, após a devida construção da edificação, é de dar, pela entrega da coisa pronta $^{132}$, ainda que em nosso ordenamento jurídico a transferência da propriedade imóvel se perfaça mediante registro do negócio jurídico no Cartório de Registro de Imóveis, o que, geralmente, está sujeito a ato pessoal, logo, obrigação de fazer ${ }^{133}$.

\footnotetext{
${ }^{131}$ GOMES, Orlando. Contratos, cit., 26. ed., 2007, p. 553. O entendimento de Orlando Gomes é corroborado por Melhim Chalhub, que define, igualmente, a natureza obrigacional do contrato de incorporação, caracterizada pelas obrigações de fazer e dar (promover a construção e entregar as unidades aos adquirentes), além do elemento de natureza real, que é a atribuição ao adquirente da propriedade do imóvel pronto (CHALHUB, Melhim Namem. Alienação fiduciária, incorporação imobiliária e mercado de capitais: estudos e pareceres, cit., p. 242). Everaldo Cambler exemplifica, contudo, como obrigação de fazer a transferência do direito real e como obrigação de dar a tradição física da unidade condominial, e critica a lição de Orlando Gomes, identificando que a transferência do direito real só se dá com o registro, que se realiza por intermédio de uma obrigação de fazer. Referido autor prossegue definindo que se o devedor tiver que confeccionar a coisa trata-se de obrigação de fazer, e, se a coisa estiver pronta, trata-se de obrigação de dar, comportando a construção, em caso de descumprimento, aplicação dos artigos do Código de Processo Civil que se referem à execução de obrigação de fazer. (Responsabilidade civil na incorporação imobiliária, cit., p. 62). Assiste razão ao entendimento de que, enquanto a coisa não existe, a solução é a execução de obrigação de fazer, uma vez que o devedor, no caso, não poderá nem depositar a coisa, nem entregá-la, por completa inexistência da coisa, conforme art. 622 do Código de Processo Civil: "O devedor poderá depositar a coisa, em vez de entregá-la, quando quiser opor embargos.".

${ }^{132}$ Destacamos a lição de Clovis Couto e Silva, em A obrigação como processo. Rio de Janeiro: Ed. FGC, 2006. p. 85, que afirma que as obrigações de dar coincidem com a atribuição patrimonial, incluindo-se, portanto, a transferência da propriedade de coisa existente, e as de fazer recaem sobre atividades determinadas. Nesse sentido, e com base na doutrina anteriormente citada, pode-se a afirmar que a transferência da propriedade é comumente tida como obrigação de dar.

${ }^{133} \mathrm{O}$ art. 481 do Código Civil define que pela compra e venda o vendedor obriga-se a transferir o domínio de certa coisa, mediante pagamento do preço pelo comprador, definindo a compra e venda como contrato consensual. Tal artigo dispõe da seguinte forma: "Art. 481 - Pelo contrato de compra e venda, um dos contratantes se obriga a transferir o domínio de certa coisa, e o outro, a pagar-lhe certo preço em dinheiro.". Orlando Gomes define o compromisso de compra e venda como contrato típico pelo qual as partes se obrigam reciprocamente a tornar eficaz a compra e venda de um bem imóvel, mediante a reprodução do consentimento no título hábil, indicando, assim, que há necessidade de ação humana, um fazer, para que haja efetivação da venda, pela reprodução do consentimento no título hábil (GOMES, Orlando. Direitos reais. Coordenador Edvaldo Brito. 20. ed. atualizada por Luiz Edson Fachin. Rio de Janeiro: Forense, 2010. p. 332).
} 


\section{OBRIGAÇÕES DAS PARTES}

\subsection{Obrigações do incorporador}

Realizada a devida apresentação da incorporação imobiliária, serão objeto de análise as obrigações imputadas às partes, reiterando-se que as obrigações do incorporador buscam o seu fim maior, consubstanciado na consecução da obrigação de resultado relativa à entrega das unidades autônomas aos adquirentes, na forma prevista no memorial de incorporação, e à atribuição, ao adquirente, da propriedade sobre tal unidade.

\subsubsection{Obrigações pré-contratuais}

Podem-se segregar as obrigações do incorporador em obrigações legais ${ }^{134}$ e contratuais, de acordo com a existência de disposição legal ou constante do próprio negócio jurídico, havendo obrigações exigíveis antes, durante e mesmo após a conclusão da obra.

As obrigações legais prévias ao início da incorporação são, basicamente, relativas ao registro da incorporação no Cartório de Registro de Imóveis, com a consignação nos documentos preliminares do prazo de carência, se houver, e à celebração dos contratos relativos à fração ideal do terreno e à construção e à elaboração da convenção condominial, a seguir detalhadas.

\subsubsection{Registro}

De acordo com o art. 32 da Lei 4.591/64 ${ }^{135}$, a negociação relacionada às unidades autônomas só pode ser realizada após o arquivo de determinados documentos no Cartório de Registro de Imóveis ${ }^{136}$, sendo, portanto, um elemento formal da incorporação.

\footnotetext{
${ }^{134}$ As obrigações legais são, na realidade, deveres. Conforme CHALHUB, Melhim Namem. Da incorporação imobiliária, cit., p. 156.

135“Art. 32. O incorporador somente poderá negociar sobre unidades autônomas após ter arquivado, no cartório competente de Registro de Imóveis, os seguintes documentos: (...)”.

${ }^{136}$ Verifique-se que referido art. 32 menciona o termo "arquivamento do memorial". Contudo, o art. 167, I, 17 , da Lei $n^{\circ} 6.015 / 73$, atinente a registros públicos, menciona o termo "registro da incorporação". Não obstante a divergência de termos, entendemos que se trata do mesmo requisito de atuação imposto ao incorporador, de forma que se garanta a devida publicidade do empreendimento e de suas condições, por meio do Cartório de Registro de Imóveis.
} 
Entre os documentos exigidos ${ }^{137}$ estão prova da aquisição de direitos sobre o terreno, certidões relacionadas ao terreno, ao proprietário do terreno e ao incorporador, projeto de construção aprovado pelas autoridades competentes, cálculo das áreas da edificação e das unidades e a discriminação das frações ideais de terreno com as unidades autônomas que a elas corresponderão, memorial descritivo das especificações da obra projetada, segundo modelo a que se refere o inciso IV, do art. 53, da Lei ${ }^{138}$, avaliação do custo global da obra, minuta da futura convenção de condomínio, declaração expressa quanto a eventual prazo de carência, entre outros.

Todos os documentos previstos na lei são exigidos para dar maior conforto aos adquirentes, especialmente no que se refere às informações relevantes do empreendimento, que devem ser integralmente de conhecimento daqueles, e à garantia de transferência da propriedade das unidades autônomas, ao final da atividade incorporativa.

Exemplificativamente, a prova de aquisição de direitos sobre o terreno assegura que o incorporador tem poderes para construir no terreno e promover, de fato, a incorporação.

\footnotetext{
${ }^{137}$ Os incisos de tal artigo trazem a relação, não sendo, contudo, taxativa: "a) título de propriedade de terreno, ou de promessa, irrevogável e irretratável, de compra e venda ou de cessão de direitos ou de permuta do qual conste cláusula de imissão na posse do imóvel, não haja estipulações impeditivas de sua alienação em frações ideais e inclua consentimento para demolição e construção, devidamente registrado; b) certidões negativas de impostos federais, estaduais e municipais, de protesto de títulos de ações cíveis e criminais e de ônus reais relativas ao imóvel, aos alienantes do terreno e ao incorporador; c) histórico dos títulos de propriedade do imóvel, abrangendo os últimos 20 anos, acompanhado de certidão dos respectivos registros; $d$ ) projeto de construção devidamente aprovado pelas autoridades competentes;e) cálculo das áreas das edificações, discriminando, além da global, a das partes comuns, e indicando, cada tipo de unidade a respectiva metragem de área construída; $f$ ) certidão negativa de débito para com a Previdência Social, quando o titular de direitos sobre o terreno fôr responsável pela arrecadação das respectivas contribuições; $g$ ) memorial descritivo das especificações da obra projetada, segundo modelo a que se refere o inciso IV, do art. 53, desta Lei; $h$ ) avaliação do custo global da obra, atualizada à data do arquivamento, calculada de acordo com a norma do inciso III, do art. 53 com base nos custos unitários referidos no art. 54, discriminando-se, também, o custo de construção de cada unidade, devidamente autenticada pelo profissional responsável pela obra;i) discriminação das frações ideais de terreno com as unidades autônomas que a elas corresponderão;j) minuta da futura Convenção de condomínio que regerá a edificação ou o conjunto de edificações; l) declaração em que se defina a parcela do preço de que trata o inciso II, do art. $39 ; m)$ certidão do instrumento público de mandato, referido no $\S 1^{\circ}$ do artigo $\left.31 ; n\right)$ declaração expressa em que se fixe, se houver, o prazo de carência (art. 34);o) atestado de idoneidade financeira, fornecido por estabelecimento de crédito que opere no País há mais de cinco anos;p) declaração, acompanhada de plantas elucidativas, sobre o número de veículos que a garagem comporta e os locais destinados à guarda dos mesmos.”.

${ }^{138} \mathrm{Tal}$ artigo faz referência à padronização de tal modelo pela ABNT - Associação Brasileira de Normas Técnicas e tem a seguinte redação: "Art. 53. O Poder Executivo, através do Banco Nacional da Habitação, promoverá a celebração de contratos com a Associação Brasileira de Normas Técnicas (A.B.N.T.), no sentido de que esta, tendo em vista o disposto na Lei $n^{\circ} 4.150$, de novembro de 1962, prepare, no prazo máximo de 120 dias, normas que estabeleçam, para cada tipo de prédio que padronizar: (...) IV - modelo de memorial descritivo dos acabamentos de edificação, para fins do disposto no art. 32;".
} 
As certidões de distribuidores e eventual atestado de idoneidade financeira são indícios da situação e qualificação do incorporador ${ }^{139}$. Como há previsão de apresentação de tais certidões também dos alienantes do terreno, reduzem-se os riscos de evicção ${ }^{140}$.

O projeto de construção, a discriminação das áreas da edificação e das unidades e o memorial descritivo das obras demonstram de que forma será realizado o empreendimento e, ainda, as unidades a serem adquiridas.

Em suma, os requisitos do art. 32 visam a assegurar a adequada demonstração do empreendimento.

A documentação, para que seja arquivada, submete-se a exame pelo Oficial de Registro de Imóveis ${ }^{141}$, podendo este exigir apresentação do que julgar necessário. Satisfeitas as referidas exigências ${ }^{142}$, o Oficial poderá proceder ao registro, ficando o Oficial sujeito a responsabilidade, nos termos do parágrafo $7^{\circ}$, com as ressalvas do parágrafo $9^{\circ}$, ambos do art. $32^{143}$.

O rol do art. 32, entretanto, não é exaustivo. Há, por exemplo, outro documento que deve compor o registro da incorporação, constante do art. 67 da lei em questão: o contratopadrão, que conterá, minimamente, as condições aplicáveis a todos os adquirentes, ainda que o contrato específico de cada um deles contenha condições variáveis ${ }^{144}$.

\footnotetext{
${ }^{139}$ Segundo Caio Mario da Silva Pereira, trata-se de requisito inócuo, sendo "atestação meramente graciosa", não oferecendo maior segurança aos adquirentes. PEREIRA, Caio Mário da Silva. Condomínio e incorporações, cit., p. 266.

${ }^{140}$ Cabe esclarecer que a evicção, caracterizada pela perda, total ou parcial, da coisa pelo adquirentee em virtude de sentença judicial que atribui a terceiro a sua propriedade, não se confunde com os vícios redibitórios, pois a evicção é vício de direito e os vícios redibitórios vícios na coisa. A definição é doutrinária, uma vez que o Código Civil não define seu conceito, apenas menciona suas consequências.

${ }^{141}$ Conforme parágrafo primeiro do art. 32 , assim redigido: "\$ $1^{\circ}$ A documentação referida neste artigo, após o exame do Oficial de Registro de Imóveis, será arquivada em cartório, fazendo-se o competente registro.”.

${ }^{142}$ Trata-se de disposição contida no parágrafo sexto do art. 32 da lei: "§ $6^{\circ}$ Os Oficiais de Registro de Imóveis terão 15 dias para apresentar, por escrito, todas as exigências que julgarem necessárias ao arquivamento, e, satisfeitas as referidas exigências, terão o prazo de 15 dias para fornecer certidão, relacionando a documentação apresentada, e devolver, autenticadas, as segundas vias da mencionada documentação, com exceção dos documentos públicos. Em casos de divergência, o Oficial levantará a dúvida segundo as normas processuais aplicáveis.".

143، $§ 7^{\circ}$ O Oficial de Registro de Imóveis responde, civil e criminalmente, se efetuar o arquivamento de documentação contraveniente à lei ou der certidão sem o arquivamento de todos os documentos exigidos." "§ $9^{\circ}$ Oficial do Registro de Imóveis não responde pela exatidão dos documentos que lhe forem apresentados para arquivamento em obediência ao disposto nas alíneas e, g, h, l, e p deste artigo, desde que assinados pelo profissional responsável pela obra."

${ }^{144}$ Art. 67. Os contratos poderão consignar exclusivamente às cláusulas, termo ou condições variáveis ou específicas. $\S 1^{\circ}$ As cláusulas comuns a todos os adquirentes não precisarão figurar expressamente nos respectivos contratos. $\S 2^{\circ}$ Os contratos, no entanto, consignarão obrigatoriamente que as partes contratantes, adotem e se comprometam a cumprir as cláusulas, termos e condições contratuais a que se refere o parágrafo anterior, sempre transcritas, verbo ad verbum no respectivo cartório ou ofício,
} 
Segundo o art. 33 da Lei 4.591/64 $4^{145}$, referido registro será válido pelo prazo de cento e oitenta dias, findo o qual, se a incorporação ainda não se houver concretizado, por meio da alienação de qualquer unidade, o incorporador só poderá negociar as unidades depois de atualizar a documentação a que se refere o artigo 32, revalidando-se, portanto, o registro por igual prazo, sendo que tal revalidação só pode ser feita uma vez.

Com o registro compatível com a lei, fica o incorporador autorizado a prosseguir com a incorporação, inclusive promover a comercialização das unidades autônomas.

Caso o incorporador realize a venda de unidades autônomas sem ter efetuado o registro prévio da incorporação, a lei prevê as sanções de contravenção à economia popular, conforme art. $66^{146}$.

Tal medida justifica-se porque o incorporador fere, em tese, direito essencial dos adquirentes, que é receber todas as informações atinentes ao empreendimento.

A sanção decorrente da não observância do disposto no art. 32 supracitado limitase à indicada no art. 66, pois o entendimento majoritário ${ }^{147}$ é de que, apesar de se tratar de contravenção prevista em lei, não se deve negar validade ao contrato celebrado com o adquirente, ainda que haja a irregularidade da ausência de registro, podendo ser a falta suprida, conforme leciona Melhim Chalhub ${ }^{148}$.

\footnotetext{
mencionando, inclusive, o número do livro e das folhas do competente registro. $\S 3^{\circ}$ Aos adquirentes, ao receberem os respectivos instrumentos, será obrigatòriamente entregue cópia impressa ou mimeografada, autenticada, do contrato-padrão, contendo as cláusulas, termos e condições referidas no $\S 1^{\circ}$ deste artigo. $\S$ $4^{\text {o }}$ Os cartórios de Registro de Imóveis, para os devidos efeitos, receberão dos incorporadores, autenticadamente, o instrumento a que se refere o parágrafo anterior.

${ }^{145} \mathrm{O}$ artigo 33 tem a seguinte redação: "O registro da incorporação será válido pelo prazo de 180 dias, findo o qual, se ela ainda não se houver concretizado, o incorporador só poderá negociar unidades depois de atualizar a documentação a que se refere o artigo anterior, revalidando o registro por igual prazo.”.

146، Art. 66. São contravenções relativas à economia popular, puníveis na forma do artigo 10 da Lei ${ }^{\circ} 1.521$, de 26 de dezembro de 1951: I - negociar o incorporador frações ideais de terreno, sem previamente satisfazer às exigências constantes desta Lei;".

${ }^{147}$ Nesse sentido, decisão no AgRg 2008/0267297-9 nos EDcl no REsp 1107117/SC, Rel. Ministro VASCO DELLA GIUSTINA, Terceira Turma do STJ, julg. em 22/02/2011: “(...)5. O descumprimento, pela incorporadora, da obrigação constante no art. 32 da Lei 4.591/64, consistente no registro do memorial de incorporação no Cartório de Imóveis, não implica a nulidade ou anulabilidade (nulidade relativa) do contrato de promessa de compra e venda de unidade condominial, tampouco impede, ao ex-titular de direito à aquisição de unidade autônoma, a reparação a que alude o art. 40 da Lei 4.591/64. Precedentes...”. Ainda, decisão mais antiga, no REsp 192315/MG, Rel. Min. Sálvio de Figueiredo Teixeira, Quarta Turma do STJ, julg. em 13/11/2001, no seguinte sentido: “(...) I - A jurisprudência desta Corte afasta a nulidade ou a anulabilidade(nulidade relativa) do contrato de promessa de compra e venda por descumprimento do art. 32 da Lei n. 4.591/64, que exige o registro do memorial da incorporação no Cartório de Imóveis. II - Todavia, se não sanada a irregularidade, pode o promissário comprador postular a resolução do contrato de promessa de compra e venda, em face do inadimplemento da obrigação por parte da incorporadora."

${ }^{148}$ CHALHUB, Melhim Namem. Da incorporação imobiliária, cit., p. 38 e 39.
} 
Dessa forma, ainda que o adquirente não tenha recebido todas as informações, em razão da ausência do registro da documentação necessária para individualizar determinado empreendimento, o contrato celebrado é válido e vincula o incorporador, que não pode utilizar-se da própria omissão na tentativa de "invalidar" o negócio em questão, agindo, nessa tentativa, de forma contraditória, o que nosso ordenamento não homenageia.

Ainda no tocante ao registro e sua relevância, Everaldo Cambler explana que o momento do ato registral é de suma importância para a própria caracterização da incorporação: se o ato registral for realizado antes ou durante a construção do empreendimento, haverá incorporação; se realizado após a conclusão da obra, com aquisição do "habite-se", não haverá incorporação imobiliária, mas sim instituição de condomínio ${ }^{149}$.

Com razão, a incorporação imobiliária caracteriza-se pela alienação de unidades ou direitos sobre imóvel durante a fase de construção. Assim, havendo registro e venda posterior à referida fase, não se estará diante de hipótese de incorporação imobiliária.

\subsubsection{Prazo de carência}

Um dos elementos que compõem o registro da incorporação é o prazo de carência que pode ser estipulado pelo incorporador ${ }^{150}$.

Estabelecendo-se tal prazo, o incorporador pode avaliar o mercado e o sucesso de determinado empreendimento. Caso entenda, nesse período, que o empreendimento traz mais riscos do que certeza de êxito e lucro, o incorporador pode desistir da incorporação, desde que observe o conteúdo da lei.

Para instituição do prazo de carência, o incorporador deve, por meio de declaração referida na alínea "n" do art. 32 da lei em questão, estabelecer todas as condições que permitirão o exercício do direito de desistência pelo incorporador, nos termos do parágrafo $1^{\circ}$ do art. $34^{151}$.

\footnotetext{
${ }^{149}$ CAMBLER, Everaldo Augusto. Responsabilidade civil na incorporação imobiliária, cit., p. 50.

${ }^{150}$ Conforme autorização legal contida no art. 34 da Lei 4.591/64: "Art. 34. O incorporador poderá fixar, para efetivação da incorporação, prazo de carência, dentro do qual lhe é lícito desistir do empreendimento.”. A declaração da existência do prazo de carência está listada no rol do art. 32, igualmente.

151، $\$ 1^{\circ}$ A fixação do prazo de carência será feita pela declaração a que se refere a alínea "n", do art. 32 onde se fixem as condições que autorizarão o incorporador a desistir do empreendimento."
} 
Essa previsão vai ao encontro do princípio da boa-fé e dos princípios constantes do Código de Defesa do Consumidor relativos à informação, de forma que os adquirentes estarão amplamente cientes das condições que permearão o exercício, pelo incorporador, de seu direito de desistência do empreendimento.

Nos termos da lei, o prazo de carência não pode ser prorrogado e não pode ser estipulado em prazo superior ao da validade do registro da incorporação, considerando, contudo, o período de revalidação do registro ${ }^{152}$.

Para que haja devida desistência da incorporação, o incorporador deve denunciar, por escrito, ao Cartório de Registro de Imóveis competente, bem como comunicar, igualmente por escrito, a denúncia a todos aqueles que celebraram algum contrato ou documento preliminar com o incorporador ${ }^{153}$.

Deixando o incorporador de exercer seu direito de desistir do empreendimento, a obrigação contida no art. 35 da Lei 4.591/64 persistirá, podendo o adquirente registrar o contrato ou documento que houver celebrado com o incorporador, adquirindo, desde o registro, direito real e consequente direito à obtenção compulsória do contrato correspondente, bem como cobrar por via executiva a multa prevista no parágrafo $5^{\circ}$ do artigo em comento, de cinquenta por cento sobre o valor que efetivamente tiver pago ao incorporador ${ }^{154}$.

Merece destacar que, ainda que a obrigação de denunciar seja primariamente do incorporador, a lei, no $\S 3^{\circ}$ do art. $35^{155}$, prevê a possibilidade de o outorgante do mandato de que trata o $\S 1^{\circ}$ do art. 31 proceder à denúncia, no prazo de cinco dias do término do

\footnotetext{
${ }^{152}$ Conforme $\S 2^{\circ}$ e $6^{\circ}$ do art. 34 , cujo teor é, respectivamente: "§ $2^{\circ}$ Em caso algum poderá o prazo de carência ultrapassar o termo final do prazo da validade do registro ou, se for o caso, de sua revalidação." e "§ $6^{\circ} \mathrm{O}$ prazo de carência é improrrogável".

${ }^{153}$ Nos termos do $\S 4^{\circ}$ do art 34 , cuja redação é a seguinte: "§ $4^{\circ}$ A desistência da incorporação será denunciada, por escrito, ao Registro de Imóveis e comunicada, por escrito, a cada um dos adquirentes ou candidatos à aquisição, sob pena de responsabilidade civil e criminal do incorporador.”.

${ }^{154}$ Conforme $\S 4^{\circ}$ e $5^{\circ}$ do art. 35 em questão: " $\$ 4^{\circ}$ Descumprida pelo incorporador e pelo mandante de que trata o $\S 1^{\circ}$ do art. 31 a obrigação da outorga dos contratos referidos no caput deste artigo, nos prazos ora fixados, a carta-proposta ou o documento de ajuste preliminar poderão ser averbados no Registro de Imóveis, averbação que conferirá direito real oponível a terceiros, com o conseqüente direito à obtenção compulsória do contrato correspondente." e "§ $5^{\circ} \mathrm{Na}$ hipótese do parágrafo anterior, o incorporador incorrerá também na multa de $50 \%$ sobre a quantia que efetivamente tiver recebido, cobrável por via executiva, em favor do adquirente ou candidato à aquisição.".

155، $§ 3^{\circ} \mathrm{Se}$, dentro do prazo de carência, o incorporador não denunciar a incorporação, embora não se tenham reunido as condições a que se refere o $\S 1^{\circ}$, o outorgante do mandato de que trata o $\S 1^{\circ}$, do art. 31, poderá fazê-lo nos cinco dias subseqüentes ao prazo de carência, e nesse caso ficará solidàriamente responsável com o incorporador pela devolução das quantias que os adquirentes ou candidatos à aquisição houverem entregue ao incorporador, resguardado o direito de regresso sobre eles, dispensando-se, então, do cumprimento da obrigação fixada no caput deste artigo.”.
} 
prazo de carência, ficando, nessa hipótese, solidariamente responsável pela devolução das quantias que os adquirentes ou candidatos à aquisição tenham entregado ao incorporador.

$\mathrm{Na}$ hipótese de o incorporador denunciar a incorporação e deixar de restituir valores pagos pelos adquirentes ou candidatos, no prazo de trinta dias da denúncia, estes estarão legitimados a cobrar os valores em execução, com reajuste e juros, não havendo, contudo, sanção específica para esse descumprimento ${ }^{156}$.

Ainda que a ausência de sanção específica não obste o direito de o adquirente reclamar prejuízos advindos de tal descumprimento, medida salutar seria a alteração legislativa para incluir previsão de multa para o incorporador que deixasse de cumprir o prazo previsto, ou outra sanção que seja apta a coibir o descumprimento.

O prazo de carência define termo inicial do prazo para cumprimento de obrigação essencial do incorporador, que é promover a celebração do contrato correspondente à fração ideal do terreno e do contrato de construção e elaborar a convenção condominial, conforme art. 35 da Lei 4.591/64, obrigação essa que será analisada ulteriormente ${ }^{157}$.

\subsubsection{Celebração de contratos}

O primeiro dever do incorporador, após o registro da incorporação no Cartório de Registro de Imóveis e desde que não tenha exercido o incorporador o direito de denúncia no prazo de carência eventualmente estabelecido, é celebrar os contratos relativos à fração ideal do terreno e à construção, bem como proceder à convenção de condomínio, no prazo de sessenta dias, nos termos do art. 35 da lei anteriormente citado.

Assim, após o término do prazo de carência, se houver, o incorporador possui sessenta dias para efetivar as vendas, concluindo os contratos aplicáveis, devendo indicar, em tais contratos, número de registro da incorporação, nome dos responsáveis pelo custeio

\footnotetext{
${ }^{156}$ Nos termos do art. 36, que assim dispõe: “Art. 36. No caso de denúncia de incorporação, nos termos do art. 34, se o incorporador, até 30 dias a contar da denúncia, não restituir aos adquirentes as importâncias pagas, estes poderão cobrá-la por via executiva, reajustado o seu valor a contar da data do recebimento, em função do índice geral de preços mensalmente publicado pelo Conselho Nacional de Economia, que reflita as variações no poder aquisitivo da moeda nacional, e acrescido de juros de $6 \%$ ao ano, sobre o total corrigido.".

157،Art. 35. O incorporador terá o prazo máximo de 60 dias, a contar do termo final do prazo de carência, se houver, para promover a celebração do competente contrato relativo à fração ideal de terreno, e, bem assim, do contrato de construção e da Convenção do condomínio, de acordo com discriminação constante da alínea "i", do art. 32.".
} 
da obra, existência de ônus reais ou fiscais ${ }^{158}$, modo de pagamento do preço da obra e custo da fração ideal do terreno, entre outras condições.

Os contratos com os adquirentes devem alcançar o objetivo final da incorporação, que é a transmissão de propriedade da unidade autônoma devidamente construída e individualizada.

A contratação pode ser realizada de diversas formas, desde que permita atingir a finalidade da incorporação. Comumente, o contrato celebrado com os adquirentes é o compromisso de compra e venda da unidade caracterizada como coisa futura, o que melhor assegura os interesses do adquirente, ou compromisso de compra e venda de fração ideal do terreno com contrato de construção relacionado à acessão, ou mesmo contrato de venda com pacto adjeto de alienação fiduciária ${ }^{159}$.

No tocante ao compromisso de compra e venda, contrato mais utilizado nas incorporações imobiliárias, sua tipificação em nosso ordenamento ocorreu por meio do Decreto-Lei $n^{\circ}$ 58/37.

Até edição do Decreto-Lei 58/37, tal negócio conferia aos adquirentes apenas direitos obrigacionais. Orlando Gomes ${ }^{160}$, por exemplo, justifica maior regulação pela necessidade de proteção daqueles que adquiriram terreno loteado em prestações, uma vez que, anteriormente, se o compromissário comprador deixasse de pagar uma das prestações, perdia direito a todas as pagas, além de que não havia medida de forçar o adimplemento do promitente vendedor para celebração do contrato definitivo, ensejando, apenas, a indenização por perdas e danos.

A Lei n ${ }^{\circ}$ 649/49 estendeu o regime geral das promessas de compra e venda aos imóveis não loteados, desde que não contivessem cláusula de arrependimento e estivessem registradas em cartório de registro imobiliário.

\footnotetext{
${ }^{158}$ Veja-se que nem todo ônus pode impedir a realização da incorporação, cabendo ao incorporador, conforme prevê a lei, indicar adequadamente qual ônus incide sobre o terreno, de forma que o adquirente conheça as características do empreendimento e a extensão do ônus. Conforme PEREIRA, Caio Mário da Silva. Condomínio e incorporações, cit., p. 270.

${ }^{159}$ Como explicita CHALHUB, Melhim Namem. Da incorporação imobiliária, cit., p. 174 e ss.

${ }^{160}$ GOMES, Orlando. Direitos reais, cit., p. 330.
} 
A Lei $n^{\circ} 6.766 / 79$, que trata do parcelamento do solo, prevê, em seu art. $25^{161}$, que os compromissos de compra e venda que atribuam direito à adjudicação compulsória são irretratáveis, gerando direito real oponível a terceiros, se registrados.

Ademais, referida lei prevê que os compromissos de compra e venda podem ser celebrados por escritura pública ou por instrumento particular ${ }^{162}$.

Ratificando tal entendimento está a norma contida no art. $462^{163}$ do Código Civil, que define que a validade do pré-contrato requer observância dos requisitos essenciais ao contrato a ser celebrado, exceto no que diz respeito à sua forma.

Há entendimentos de que o compromisso de compra e venda não pode ser definido como mero contrato preliminar, sendo desnecessária nova declaração de vontade, pois, ao se celebrar pré-contrato, tudo que é necessário ao estabelecimento do vínculo contratual definitivo já foi estipulado, bastando, portanto, sua execução, mediante outorga de escritura e registro no Cartório de Imóveis, que não constitui novo negócio jurídico, mas "ato devido que expressa o cumprimento da obrigação assumida no primeiro contrato"164.

Ainda, ao conferir ao compromissário direito real, pode haver dispensa de nova declaração de vontade, bastando que se peça ao juiz que supra a vontade faltante, por meio de adjudicação compulsória ${ }^{165}$.

\footnotetext{
161““Art. 25. São irretratáveis os compromissos de compra e venda, cessões e promessas de cessão, os que atribuam direito a adjudicação compulsória e, estando registrados, confiram direito real oponível a terceiros.".

${ }^{162}$ Conforme art. 26: "Os compromissos de compra e venda, as cessões ou promessas de cessão poderão ser feitos por escritura pública ou por instrumento particular, de acordo com o modelo depositado na forma do inciso VI do art. 18 e conterão, pelo menos, as seguintes indicações: (...)". Oportunamente, trazemos à baila entendimento esposado pelo Min. Barros Monteiro, relator do Resp 116.882-DF, julgado em 19.04.2001, em voto vencido, de que o compromisso de compra e venda pode ser ultimado inclusive por proposta: “(...) É sabido, por outro lado, que após o advento da Lei 6766/79 o compromisso de compra e venda, ainda que preliminar, ou ultimado por uma proposta aceita pelo alienante, ou outro qualquer instrumento, do qual conste manifesta a vontade dos contratantes, confere direito ao adquirente e não pode ser imotivadamente rescindido pelo compromitente vendedor, notadamente, quando inexiste cláusula de arrependimento." (sic)

163“'Art. 462. O contrato preliminar, exceto quanto à forma, deve conter todos os requisitos essenciais ao contrato a ser celebrado."

${ }^{164}$ AZEVEDO JR., José Osório de. Compromisso de compra e venda. São Paulo: Malheiros Ed., 2006. p. 23.

${ }^{165} \mathrm{O}$ art. 32, parágrafo $2^{\circ}$, da Lei $\mathrm{n}^{\circ} 4591 / 64$, define que os contratos de compra e venda, promessa de venda, cessão ou promessa de cessão de unidades autônomas celebrados entre as partes, irretratáveis, conferem, após o registro, direito real oponível a terceiros, atribuindo ao adquirente direito a adjudicação compulsória. Muito se discutiu sobre a questão da ação de adjudicação compulsória e a necessidade de registro do contrato. O STF ocasionalmente julgava pela prescindibilidade do registro do compromisso de compra e venda, até que a Lei de Loteamentos (Lei no 6766/79) trouxe novos elementos ao debate, fortalecendo a tese da prescindibilidade do registro. $\mathrm{O}$ art. 25 de referida lei confere, mediante registro, direito real oponível a terceiros, pois o registro relaciona-se à oponibilidade, mas não à condição para a adjudicação compulsória. A doutrina já havia pacificado o entendimento de que era dispensado o registro para a adjudicação compulsória, quando o assunto virou objeto da Súmula 239 do Superior Tribunal de Justiça, que definia que o direito à adjudicação compulsória não dependia do registro. Entretanto, o Código Civil de
} 
De fato, o compromisso de compra e venda deixou de ser mero contrato preliminar, possuindo características próprias, especialmente pela previsão do direito real e pela possibilidade de, mediante quitação da dívida, se formalizar a transferência de propriedade, pelo Registro de Imóveis ${ }^{166}$.

Outra possibilidade é a utilização do contrato de venda com pacto adjeto de alienação fiduciária, que, no âmbito do mercado imobiliário, se caracteriza pela transmissão da propriedade resolúvel de um imóvel ao credor, em garantia a uma dívida ${ }^{167}$.

Com a constituição da propriedade fiduciária, o devedor fiduciante permanece com a posse direta sobre o bem, mas a posse indireta torna-se do credor fiduciário ${ }^{168}$.

Até quitação da dívida, a propriedade permanece com o fiduciário, sendo tal propriedade resolúvel, de forma que este não pode consolidar a propriedade, a não ser que haja descumprimento, pelo devedor, de sua obrigação de pagamento.

Mediante pagamento da dívida, e sem que seja necessária qualquer outra manifestação de vontade ${ }^{169}$, basta que o devedor comprove, no Registro de Imóveis, o devido pagamento, apresentando termo de quitação a ser fornecido pelo fiduciário no prazo de trinta dias da respectiva liquidação, sob pena de multa ${ }^{170}$.

A alienação fiduciária de imóveis pode envolver o incorporador e o adquirente ou os dois e a financiadora, em um ou separados contratos, tratando-se, no caso, de coligação de contratos.

2002 voltou a trazer a problemática à baila, em razão de sua redação confusa: o art. 1.225 determina como um direito real o direito do promitente comprador, mas os artigos 1.417 e 1.418 atrapalham o entendimento que se tinha, pois indica o primeiro que apenas com o registro se adquire direito real à aquisição do imóvel. Não obstante a redação do Código Civil, o CJF aprovou o Enunciado 95 na I Jornada de Direito Civil, definindo a dispensa do registro.

${ }^{166}$ Nos termos do parágrafo $6^{\circ}$ do art. 26 da Lei $n^{\circ}$ 6.766/79: "§ $6^{\circ}$ Os compromissos de compra e venda, as cessões e as promessas de cessão valerão como título para o registro da propriedade do lote adquirido, quando acompanhados da respectiva prova de quitação".

${ }^{167}$ Conforme art. 22 da Lei $\mathrm{n}^{\mathbf{o}}$ 9.514/97, que dispõe sobre o Sistema de Financiamento Imobiliário: "A alienação fiduciária regulada por esta Lei é o negócio jurídico pelo qual o devedor, ou fiduciante, com o escopo de garantia, contrata a transferência ao credor, ou fiduciário, da propriedade resolúvel de coisa imóvel.".

${ }^{168}$ Nos termos do parágrafo único do art. 23 da lei correspondente: "Com a constituição da propriedade fiduciária, dá-se o desdobramento da posse, tornando-se o fiduciante possuidor direto e o fiduciário possuidor indireto da coisa imóvel.”.

${ }^{169}$ Em relação, especificamente, ao compromisso de compra e venda, com base na tese, não unânime, de que se trata de contrato preliminar a depender de nova manifestação de vontade.

${ }^{170}$ Veja-se o termo da lei: “Art. 25. Com o pagamento da dívida e seus encargos, resolve-se, nos termos deste artigo, a propriedade fiduciária do imóvel. $\S 1^{\circ}$ No prazo de trinta dias, a contar da data de liquidação da dívida, o fiduciário fornecerá o respectivo termo de quitação ao fiduciante, sob pena de multa em favor deste, equivalente a meio por cento ao mês, ou fração, sobre o valor do contrato.”. 
Ainda que seja igualmente um contrato de garantia, diverge, por exemplo, da hipoteca, pois esta é garantia sobre bens de terceiro, uma vez que o devedor mantém-se proprietário do bem.

Pela complexidade da incorporação imobiliária, diversos outros contratos podem ser formalizados, como o contrato de permuta ou promessa de permuta de terreno e unidades autônomas oriundas do empreendimento; o de financiamento, tanto pelo próprio incorporador, para realização da obra e do empreendimento no geral, quanto pelos adquirentes, para aquisição da unidade autônoma; entre outros.

No tocante ao financiamento, cabe esclarecer que, se relativo às obras, gera ao incorporador a obrigação de repasse dos valores obtidos pela venda das unidades, uma vez que o custo de eventual financiamento é arcado direta ou indiretamente pelos adquirentes.

Há, inclusive, como cita Chalhub ${ }^{171}$, costume de se estabelecer ao incorporador um prazo de carência após o término das obras para resgate da dívida decorrente do financiamento, o que se dá, ainda sob a ótica de tal doutrinador, por meio de cessão de crédito à financiadora.

Ainda que a construção não seja elemento essencial do contrato de incorporação, já que o incorporador não é necessariamente o construtor, a lei prevê que no mesmo prazo de sessenta dias deverá o incorporador celebrar o contrato de construção.

Trata-se de segurança aos adquirentes, uma vez que a celebração desse contrato permite a consecução da finalidade do empreendimento, por não haver meio de se transferir a propriedade da unidade autônoma devidamente construída e individualizada sem que esta seja, de fato, construída.

A contratação da construção atrela-se à determinação das modalidades conhecidas da incorporação imobiliária, podendo ser por empreitada ou por administração.

Repise-se que, como propulsor do empreendimento, cabe ao incorporador proceder à celebração do contrato de construção, ainda que não seja o próprio construtor, de forma a garantir que as obras sejam realizadas para consecução do objetivo da incorporação.

No tocante à convenção do condomínio, lei maior que rege a relação entre os condôminos, apesar de não se tratar de contrato a ser celebrado, deve ser elaborada

\footnotetext{
${ }^{171}$ CHALHUB, Melhim Namem. Da incorporação imobiliária, cit., p. 201.
} 
pelo incorporador, já que a incorporação imobiliária relaciona-se à instituição do condomínio especial.

Independentemente da modalidade do contrato, se houver descumprimento, pelo incorporador, do dever de formalizar os contratos em questão, o adquirente terá o direito de efetivar a averbação do título preliminar que contenha os elementos mínimos para se configurar a relação contratual ${ }^{172}$ no Cartório de Registro de Imóveis, de maneira que se constitua direito real oponível a terceiros e que, assim, possa obter compulsoriamente o contrato correspondente ${ }^{173}$. Ainda, fica o incorporador sujeito ao pagamento de multa prevista no art. 35 , parágrafo $5^{\mathbf{0} 174}$, no montante correspondente a cinquenta por cento sobre a quantia que o incorporador tiver de fato recebido.

\subsubsection{Obrigações contratuais}

As obrigações contratuais do incorporador são, em suma, promover e coordenar a construção da edificação; entregar a unidade condominial pronta e acabada para utilização conforme memorial de incorporação, constituído o condomínio especial; e, por fim, transferir a propriedade da unidade autônoma.

\subsubsection{Construção}

Não obstante a definição legal das modalidades de incorporação com base na forma da construção, citadas adiante, a Lei no 4.591/64 refere-se, nos arts. 41 a 43, ao contrato pelo qual o incorporador se obriga a entregar as unidades prontas por um preço global $^{175}$, englobando tanto a quota de aquisição de direitos sobre o terreno quanto a de aquisição de direitos relativos à construção e à acessão correspondente.

\footnotetext{
${ }^{172}$ Segundo Everaldo Cambler, não é qualquer documento preliminar que tem o condão de registro, como minutas de contrato, recibos de reservas, os quais não possuem dados essenciais do contrato definitivo, nem mesmo definem a fração ideal sobre o que incidirá o direito real a ser constituído, tornando a averbação impossível. CAMBLER, Everaldo Augusto. Responsabilidade civil na incorporação imobiliária, cit., p. 201.

${ }^{173}$ Conforme parágrafo $4^{\circ}$ do art. 35 da Lei no 4591/64, que assim dispõe: "Descumprida pelo incorporador e pelo mandante de que trata o $\S 1^{\circ}$ do art. 31 a obrigação da outorga dos contratos referidos no caput dêste artigo, nos prazos ora fixados, a carta-proposta ou o documento de ajuste preliminar poderão ser averbados no Registro de Imóveis, averbação que conferirá direito real oponível a terceiros, com o conseqüente direito à obtenção compulsória do contrato correspondente.”.

174“ $\mathrm{Na}$ hipótese do parágrafo anterior, o incorporador incorrerá também na multa de $50 \%$ sôbre a quantia que efetivamente tiver recebido, cobrável por via executiva, em favor do adquirente ou candidato à aquisição."

${ }^{175}$ Tal é a lição de FRANCO, João Nascimento; GONDO Nisske. Incorporações imobiliárias, cit., p. 119.
} 
Tal contratação equivale, segundo Chalhub, ao frequente contrato de promessa de compra e venda da unidade como coisa futura, "em que o incorporador assume o risco da construção, estabelecendo desde logo o preço final da unidade e obrigando-se a entregá-la concluída e averbada no Registro de Imóveis." ${ }^{176}$.

Nesse caso, que é o que de melhor forma protege os adquirentes, não há segregação prática entre o preço de fração ideal do terreno e o preço de construção ${ }^{177}$, uma vez que o incorporador obriga-se a entregar coisa futura, mediante pagamento de valor previamente por ele definido, sendo vedado ao incorporador a alteração das condições de pagamento de foma unilateral ${ }^{178}$, de forma que este assume qualquer risco associado a eventual adicional sobre o valor previsto ${ }^{179}$.

Ressalte-se que o contrato de venda de coisa futura é referido no art. 483 do Código Civil $^{180}$, seguindo-se ordenamentos jurídicos estrangeiros, como o francês ${ }^{181}$, que prevê tal contrato no art. 1.130 do Código Civil ${ }^{182}$.

No tocante à incorporação imobiliária, apesar de, no momento da celebração do contrato, só existir a fração ideal, tem-se possível, desde o registro do memorial de incorporação, a individualização teórica da unidade autônoma, de forma que o objeto do contrato, ainda que se refira à coisa futura, seja determinado desde sua celebração.

Além dessa possibilidade, a Lei no 4.591/64 prevê, nos arts. 55 a 57, a modalidade de construção por empreitada, referindo-se, pois, à regulação contida nos arts. 610 a 626 do Código Civil.

Aludida modalidade prevê que o construtor, que pode ou não ser o incorporador, é responsável pela execução da obra, podendo fornecer mão-de-obra e os materiais necessários.

${ }^{176}$ CHALHUB, Melhim Namem. Da incorporação imobiliária, cit., p. 174.

${ }^{177}$ Ainda que a parte final do art. 41 mencione que "discriminar-se-ão, no contrato, o preço da quota de terreno e o da construção".

${ }^{178}$ No entanto, a lei permite o reajuste dos preços, desde que tenha expressamente previsto tal possibilidade, nos termos do art. 43, V e do art. 55.

${ }^{179}$ Conforme PINTO, Nelson Luiz Guedes Ferreira. Contrato de incorporação imobiliária, cit., p. 279.

180“Art. 483. A compra e venda pode ter por objeto coisa atual ou futura. Neste caso, ficará sem efeito o contrato se esta não vier a existir, salvo se a intenção das partes era de concluir contrato aleatório.”.

${ }^{181}$ Franco e Gondo explanam, oportunamente, que a natureza jurídica desse contrato está definida pelo art. 1.130 do Código Civil francês e pela legislação de propriedade horizontal, correspondendo, igualmente, à venda de coisa futura - vente em l'etat futur d'achevement ou vente sur plans. FRANCO, João Nascimento; GONDO Nisske. Incorporações imobiliárias, cit., p. 120.

${ }^{182}$ Art. 1.130: "Les choses futures peuvent être l'objet d'une obligation. On ne peut cependant renoncer à une succession non ouverte, ni faire aucune stipulation sur une pareille succession, même avec le consentement de celui de la succession duquel il s'agit, que dans les conditions prévues par la loi.". 
No regime da empreitada o preço pode ser fixo ${ }^{183}$ ou reajustável, sendo que na hipótese de reajuste do preço, deve haver indicação clara e precisa em relação aos critérios aplicáveis, conforme índices adotados ${ }^{184}$.

Se o contrato for omisso em relação a essa definição, há presunção legal de que se trata de preço fixo ${ }^{185}$.

Os arts. 58 a 62 da Lei 4.591/64, por sua vez, definem a construção pelo regime de administração, ficando o custeio da obra a cargo dos adquirentes, ou, conforme menciona a lei, do "condomínio dos contratantes da construção".

Veja-se, oportunamente, importante definição da contratação por $\operatorname{administração~}^{186}$ :

[...] é aquele em que o construtor se encarrega da execução de um projeto, mediante remuneração fixa ou percentual sobre o custo da obra, correndo por conta do proprietário todos os encargos econômicos do empreendimento. Nesta modalidade de contrato de construção, o construtor-administrador assume a direção e responsabilidade técnica de todos os trabalhos, incumbindo ao proprietário ou comitente o custeio da construção e as especificações estruturais e de acabamento, dentre as adequadas à obra. (...) Na construção por administração o proprietário é quem custeia a obra e só a final conhece o seu preço; na empreitada, a construção é custeada pelo empreiteiro e o preço é fixado de início. $\mathrm{O}$ empreiteiro é executor autônomo dos trabalhos ajustados; o administrador é executor dependente das deliberações do dono da obra... (grifos da autora)

Nesse caso, os adquirentes respondem pelo custeio e pela fiscalização da obra conforme definição constante do art. 58 da Lei ${ }^{\circ} 4.591 / 64^{187}$.

O incorporador e o construtor são cumpridores da vontade dos adquirentes, que dirigem a construção, por meio da Comissão de Representantes, de forma que, quando esta

\footnotetext{
${ }^{183}$ Conforme parágrafo $1^{\circ}$ do art. 55 da lei, na “empreitada a preço fixo, o preço da construção será irreajustável, independentemente das variações que sofrer o custo efetivo das obras e qualquer que sejam suas causas.".

${ }^{184}$ Nos termos do art. 55, parágrafo $2^{\circ}$ : “Na empreitada a preço reajustável, o preço fixado no contrato será reajustado na forma e nas épocas nêle expressamente previstas, em função da variação dos índices adotados, também previstos obrigatoriamente no contrato.".

${ }^{185}$ Art. 55, $\S 6^{\circ}$ : "Na forma de expressa referência, os contratos de empreitada entendem-se como sendo a preço fixo." (sic).

${ }^{186}$ MEIRELLES, Hely Lopes. Direito de construir. 8. ed. São Paulo: Malheiros Ed., 1990. p. 222.

187،Art. 58. Nas incorporações em que a construção fôr contratada pelo regime de administração, também chamado "a preço de custo", será de responsabilidade dos proprietários ou adquirentes o pagamento do custo integral de obra, observadas as seguintes disposições: (...)”.
} 
exerce poderes em nome de todos os contratantes, "não surge para o incorporador o dever de ressarcir eventuais danos oriundos de atos por ela fiscalizados ou praticados"188.

Sendo assim, o próprio condomínio formado pelos adquirentes é responsável pelo empreendimento, como ratificado no julgamento de REsp 860064 / PR, em 27/03/2012, cujo Relator foi o Ministro Raul Araújo, da Quarta Turma do Superior Tribunal de Justiça ${ }^{189}$.

O incorporador aliena a fração ideal do terreno por valor determinado e, em relação à construção, apenas estima seu custo, indicando tal estimativa no memorial de incorporação a ser registrado, bem como em qualquer contrato celebrado com os adquirentes ${ }^{190}$, observandose, ainda, que tal estimativa deve ser revista semestralmente entre a Comissão de Representantes e o construtor, nos termos do art. 60 da Lei $n^{\circ} 4.591 / 64^{191}$.

Considerando que os adquirentes determinam as obras e por elas se responsabilizam, a lei define que "todas as faturas, duplicatas, recibos e quaisquer documentos referentes às transações ou aquisições para construção, serão emitidos em nome do "condomínio dos contratantes da construção", conforme inciso I do art. 58.

Em razão dessa configuração, a modalidade em questão é denominada incorporação por regime a preço de custo, sendo que o valor devido pelos adquirentes oscila, refletindo exatamente o custo da obra, somado à taxa de administração cobrada pelo incorporador.

A vantagem dessa modalidade é que os adquirentes pagarão exatamente aquilo que for necessário para a construção da edificação ${ }^{192}$. Contudo, a desvantagem reside na

\footnotetext{
${ }^{188}$ CAMBLER, Everaldo Augusto. Responsabilidade civil na incorporação imobiliária, cit., p. 265.

${ }^{189} \mathrm{Cuja}$ ementa é a seguinte: "RECURSO ESPECIAL. CIVIL. INCORPORAÇÃO IMOBILIÁRIA. CONSTRUÇÃO A PREÇO DE CUSTO. CONDÔMINOS INADIMPLENTES. LEILÃO DAS FRAÇÕES IDEAIS. RESTITUIÇÃO DOS VALORES PAGOS. RECURSO PARCIALMENTE PROVIDO. 1. Tratando-se de construção sob o regime de administração ou preço de custo, o construtor não pode ser considerado parte legítima para figurar no polo passivo de ação cujo escopo seja a restituição de parcelas pagas diretamente ao condomínio e por ele administradas para investimento na construção. 2. No caso em exame, os proprietários do terreno e os adquirentes das frações ideais formaram condomínio, ajustando a construção de edifício, sob o regime de preço de custo. Destarte, a relação jurídica estabeleceu-se entre os condôminos e o condomínio. Os primeiros ficavam responsáveis pelos custos da obra e o segundo por sua administração, fiscalização e pelos investimentos dos valores percebidos no empreendimento imobiliário. 3 . Não há relação de consumo a ser tutelada pelo Código de Defesa do Consumidor. Na realidade, a relação jurídica, na espécie, é regida pela Lei de Condomínio e Incorporações Imobiliárias (Lei 4.591/64)...”.

${ }^{190}$ Conforme artigo 59: "No regime de construção por administração, será obrigatório constar do respectivo contrato o montante do orçamento do custo da obra, elaborado com estrita observância dos critérios e normas referidos no inciso II, do art. 53 e a data em que se iniciará efetivamente a obra.".

191،Art. 60. As revisões da estimativa de custo da obra serão efetuadas, pelo menos semestralmente, em comum entre a Comissão de Representantes e o construtor. O contrato poderá estipular que, em função das necessidades da obra sejam alteráveis os esquemas de contribuições quanto ao total, ao número, ao valor e à distribuição no tempo das prestações.”.

${ }^{192}$ Importante ressalva faz Hely Lopes Meirelles, no tocante a custo adicional por erro técnico do construtoradministrador. (MEIRELLES, Hely Lopes. Direito de construir, cit., p. 223).
} 
ausência de segurança quanto ao valor total a ser pago e na imputação, aos adquirentes, da responsabilidade pelo empreendimento, em relação aos seus próprios atos e decisões.

Ressalte-se que o art. 58, parágrafo $2^{\text {o193}}$, aplicável à modalidade da construção por administração, prevê que os pagamentos dos adquirentes sejam feitos em contas específicas, que não podem ser movimentadas livremente. Tal previsão é semelhante àquelas referidas quanto aos ordenamentos jurídicos francês e espanhol.

Nas duas modalidades de construção, os adquirentes custeiam as obras, mediante pagamento à parte do valor relativo à construção ${ }^{194}$, o que pode não ocorrer na prática, quando se tratar da incorporação realizada por meio de promessa ou venda de coisa futura por preço global, já que o incorporador, nesse caso, assume a obrigação de entregar a coisa construída e acabada, ainda que se contrate com terceiro ou se assuma a construção.

Ainda que a responsabilidade do incorporador varie, de acordo com a modalidade da incorporação, não se pode olvidar que o incorporador, mesmo não sendo o construtor ${ }^{195}$, obriga-se a contratar a construção, ficando, pois, responsável pela promoção da incorporação ${ }^{196}$.

Para Orlando Gomes, por exemplo, os contratos de construção, empreitada ou administração, permanecem individualizados e autônomos, não sendo absorvidos pelo contrato de incorporação, mas, se houver descumprimento da obrigação de promover a construção, a obrigação de fazer pode ser executada à custa do incorporador, por decisão judicial ${ }^{197}$.

\footnotetext{
193،'II - tôdas as contribuições dos condôminos para qualquer fim relacionado com a construção serão depositadas em contas abertas em nome do condomínio dos contratantes em estabelecimentos bancários, as quais, serão movimentadas pela forma que fôr fixada no contrato.”.

${ }^{194}$ Franco e Gondo mencionam que a construção pode ser pelo regime de empreitada ou de administração, sob custeio dos adquirentes das unidades autônomas, que contratam as obras diretamente com o construtor ou as incluem no contrato com o incorporador. FRANCO, João Nascimento; GONDO Nisske. Incorporações imobiliárias, cit., p. 119.

${ }^{195}$ Veja-se entendimento de que o incorporador pode ser parte de tal contrato de construção, caso seja o construtor, ou pode inicialmente contratar a construção com terceiro, com posterior subrogação pelos adquirentes (CHALHUB, Melhim Namem. Da incorporação imobiliária, cit., p. 183), ou, ainda, celebrar contrato com adquirente com "compromisso de contrato de construção" (CAMBLER, Everaldo Augusto. Incorporação imobiliária: ensaio de uma teoria geral, cit., p. 246).

${ }^{196}$ Cambler, nesse sentido, afirma o dever de o incorporador indenizar os adquirentes pelos prejuízos decorrentes da interrupção ou demora nas obras, ainda que lhe caiba direito de regresso contra o construtor, caso a irregularidade seja decorrente de fato a este imputável. Responsabilidade civil na incorporação imobiliária, cit., p. 263. Da mesma forma, Chalhub entende que em qualquer modalidade de contratação por empreitada, o incorporador responde pela entrega da unidade, devendo indenizar os adquirentes pelo prejuízo que sofrerem em razão do retardamento ou paralisação da obra, cabendo ao incorporador o direito de regresso contra o construtor. CHALHUB, Melhim Namem. Da incorporação imobiliária, cit., p. 181.

${ }^{197}$ GOMES, Orlando. Contratos, cit., 26. ed., 2008, p. 552.
} 
Ademais, a própria redação legal indica que, ainda que o incorporador não realize a construção, deve promover a construção, de forma a garantir que a construção seja implementada.

Independentemente da modalidade da incorporação, é obrigação do incorporador dar andamento regular às obras. A lei traz determinadas regras a serem por ele observadas, definindo como contravenção relativa à economia popular a paralisação ou o retardo da obra sem justa causa, sendo tal obrigação melhor analisada no capítulo 5, quanto ao atraso na entrega da coisa.

Para maior segurança dos adquirentes e consecução da finalidade da incorporação, especialmente no que se refere à construção e à entrega da obra, a lei prevê, tanto no art. 43 , referente à contratação da unidade como compra e venda de coisa futura, quanto no art. $48^{198}$, que se refere a todas as construções no âmbito da incorporação imobiliária, a necessidade de estipulação, em contrato, de prazo para entrega da coisa.

A definição de prazo para entrega da coisa é imprescindível para verificação das regras atinentes ao negócio jurídico e às obrigações, ressaltando que, segundo Humberto Theodoro Junior, uma cláusula que define a indeterminação do prazo de entrega da obra ou que permita sua prorrogação por razões inaceitáveis é muito propícia à abusividade combatida pelo Código de Defesa do Consumidor ${ }^{199}$.

Trata-se de elemento mínimo para permitir a definição do termo final da obrigação do incorporador, sendo, pois, de interesse geral o conhecimento da data de entrega das unidades prontas. Ressalte-se que tal requisito vai ao encontro do dever de informação aplicável a todos os contratantes, de forma que se crie, para o adquirente, uma expectativa real do empreendimento e de seu próprio direito.

É dever do incorporador, igualmente, manter os adquirentes informados sobre o estado das obras ${ }^{200}$, sem prejuízo de verificação direta por parte destes, pelos meios que possuem para fiscalização das obras.

\footnotetext{
${ }^{198}$ Conforme parágrafo $2^{\circ}$ de citado artigo: "Do contrato deverá constar o prazo da entrega das obras...".

${ }^{199}$ THEODORO JÚNIOR, Humberto. O contrato imobiliário e a legislação tutelar do consumo. In: (Coord.). O contrato imobiliário e a legislação tutelar do consumo. Rio de Janeiro: Forense, 2002. p. 112.

${ }^{200}$ Conforme art. 43, I: "I - informar obrigatòriamente aos adquirentes, por escrito, no mínimo de seis em seis meses, o estado da obra". Ressalte-se que, havendo instituição do patrimônio de afetação, como será visto, fica o incorporador obrigado,nos termos do art. 31-D, IV, da lei atinente a: "IV - entregar à Comissão de Representantes, no mínimo a cada três meses, demonstrativo do estado da obra e de sua correspondência com o prazo pactuado ou com os recursos financeiros que integrem o patrimônio de afetação recebidos no período, firmados por profissionais habilitados, ressalvadas eventuais modificações sugeridas pelo incorporador e aprovadas pela Comissão de Representantes;”.
} 
Outra obrigação, no que se refere à construção, é de jamais se afastar do projeto de construção e do disposto no contrato respectivo, considerando que a desobediência ao dever de seguir criteriosamente as condições indicadas no memorial constitui infração o art. 43, IV, da Lei $n^{\circ} 4.591 / 64^{201}$.

Referido artigo ${ }^{202}$ impõe a vedação de alteração do projeto, especialmente quanto à unidade do adquirente e às partes comuns, e de modificação das especificações ou desvio do plano da construção, exceto se houver autorização, de forma unânime, dos interessados, ou exigência legal.

A violação a essa obrigação será analisada oportunamente, especialmente quanto à responsabilidade do incorporador.

\subsubsection{Entrega da obra e transferência da propriedade}

Todas as obrigações relacionadas à construção estão intrinsicamente vinculadas à obrigação de finalizar a obra e entregar a unidade pronta e acabada ao adquirente, podendo haver, como será visto, direito de regresso contra o construtor se a este for imputável qualquer descumprimento da obrigação de entrega da unidade.

Contudo, requisito essencial para que se entregue a unidade é a obtenção do "habite-se", documento que atesta a conclusão da obra e que o imóvel foi construído observando-se a legislação, as exigências locais e o projeto aprovado inicialmente, sendo também denominado "Certificado de Vistoria e Conclusão de Obras"203.

\footnotetext{
${ }^{201}$ Ressalte-se entendimento de Cambler de que o art. 48, parágrafo $1^{\circ}$, da Lei $\mathrm{n}^{\mathrm{o}} 4.591 / 64$ prevê que o projeto e o memorial descritivo das edificações constituem parte integrante do contrato de construção, de forma que o construtor também está vinculado a eles. CAMBLER, Everaldo Augusto. Incorporação imobiliária: ensaio de uma teoria geral, cit., p. 136.

202،Art. 43 (...) IV- é vedado ao incorporador alterar o projeto, especialmente no que se refere à unidade do adquirente e às partes comuns, modificar as especificações, ou desviar-se do plano da construção, salvo autorização unânime dos interessados ou exigência legal;’'.

${ }^{203}$ Sendo a expedição de tal certificado ato de fiscalização dos órgãos municipais, as regras correspondentes devem ser avaliadas conforme localização da obra. A Prefeitura de São Paulo, que define o certificado em questão como: “...o documento expedido pela Prefeitura que atesta a conclusão, total ou parcial, de obra ou serviço para a qual tenha sido obrigatória a prévia obtenção de Alvará de Execução.”, traz sanções adicionais ao descumprimento de obrigação de obtenção do certificado, como as previstas no Decreto $\mathrm{n}^{\circ}$ 32.329, de 23 de setembro de 1992, que regulamenta o Código de Obras e Edificações do Município (Lei ${ }^{\circ}$ 11.228/92). SECRETARIA MUNICIPAL DE NEGÓCIOS JURÍDICOS. Leis Municipais de São Paulo. Disponível em: <http://lei.prefeitura.sp.gov.br/paginasp.html>. Acesso em: 29 dez. 2013.
} 
Após a conclusão da obra e obtenção do "habite-se", deve o incorporador providenciar a averbação da construção, que, de forma geral, significa providenciar que da matrícula do imóvel (terreno) conste a edificação construída.

Tal obrigação é indispensável ao cumprimento da obrigação do incorporador de transferir a propriedade da unidade autônoma, devidamente individualizada, ao adquirente $^{204}$. Caso o incorporador demore a cumpri-la, responderá pelas perdas e danos decorrentes da mora, segundo o art. 44 da lei ${ }^{205}$.

Não obstante a responsabilidade do incorporador, o mesmo artigo define que o construtor requererá a averbação, caso o incorporador deixe de fazê-lo, sob pena, inclusive, de responder solidariamente com o incorporador, bem como define que qualquer adquirente pode fazê-lo, se ambos forem omissos.

A lei das incorporações imobiliárias prevê, assim, que o incorporador seja responsabilizado pelo atraso ou omissão dessa obrigação, assim como define a solidariedade do construtor caso este também se omita.

Cabe mencionar que a lei não prevê prazo específico para tal providência, fazendo-se necessária a estipulação de prazo para tal obrigação para caracterização de eventual mora do incorporador, sendo evidente que essa obrigação deve ser realizada até termo final da obrigação de entrega do imóvel.

$$
\text { Segundo Caramuru }{ }^{206} \text {, }
$$

A única solução possível é a de que a imediatividade urge no instante em que algum interessado exige a providência do incorporador, exigência esta que deverá, sim, ser cumprida de imediato, para que não caracterize a demora que gera a responsabilidade civil do incorporador, nos termos do art. 44, da Lei n. 4.591/64, uma vez já tendo sido concedido o 'habite-se'.

Com razão, deve-se entender que, tão logo se conclua a obra, tem-se o termo inicial para que o incorporador cumpra referida obrigação, de forma que não pode, segundo critérios casuísticos, prolongar sem justificativa seu cumprimento.

\footnotetext{
${ }^{204}$ Chalhub cita que é o "ato que configurará a consumação das obrigações do incorporador na fase contratual”. CHALHUB, Melhim Namem. Da incorporação imobiliária, cit., p. 158.

205“Após a concessão do "habite-se" pela autoridade administrativa, o incorporador deverá requerer, a averbação da construção das edificações, para efeito de individualização e discriminação das unidades, respondendo perante os adquirentes pelas perdas e danos que resultem da demora no cumprimento dessa obrigação.”.

${ }^{206}$ FRANCISCO, Caramuru Afonso. O novo regime jurídico dos contratos: das incorporações e do registro imobiliário e da alienação fiduciária em garantia, cit., p. 75.
} 
No tocante à transferência da propriedade, estando regular a obra, conforme atestado pelo órgão responsável pela emissão do certificado de conclusão, e tendo sido averbada a construção e individualizadas as unidades autônomas, celebra-se, comumente, a escritura de venda e compra da unidade autônoma.

Analisadas as obrigações essenciais do incorporador, conforme disposições legais aplicáveis e o contrato celebrado com os adquirentes, que não pode ferir os deveres trazidos pela lei correspondente, passa-se a análise das obrigações do adquirente.

\subsection{Obrigações do adquirente}

\subsubsection{Pagamento}

Previamente, há obrigação do adquirente de comparecer para formalizar os contratos, uma vez aceita sua proposta e desde que esta contenha os requisitos legais de validade ${ }^{207}$.

Formalizado o contrato, o adquirente tem como obrigação principal o pagamento dos preços relativos ao bem incorporável, seja o preço global para aquisição da unidade como coisa futura, seja o preço referente ao terreno e à parcela da construção.

Trata-se de obrigação que inclui, além do preço de aquisição da unidade, o pagamento de impostos, taxas e outros encargos, como os condominiais.

O inadimplemento do adquirente, em relação a essa obrigação, surte efeitos diversos, de acordo com a modalidade da contratação.

Considerando as modalidades de incorporação que segregam o preço da coisa em duas parcelas, sendo a primeira relativa à aquisição da fração ideal sobre o terreno, à qual se relacionará a unidade autônoma após construída a edificação, e a segunda ao preço da construção que cabe a determinada unidade autônoma, é possível que o incorporador estipule que, havendo atraso no pagamento da parcela relativa à construção, os efeitos da mora recaiam também sobre a da aquisição da fração ideal de terreno e vice-versa.

\footnotetext{
${ }^{207}$ Caio Mario, com razão, explana que o inadimplemento, pelo adquirente, de tal obrigação de comparecer e celebrar o contrato correspondente, pode ensejar a exceptio non adimpleti contractus, de forma que o incorporador pode retardar o início da construção. PEREIRA, Caio Mário da Silva. Condomínio $e$ incorporações, cit., p. 295.
} 
Quando as unidades condominiais forem contratadas por preço global, nos termos do art. 41 da Lei $n^{\circ} 4.591 / 64$, é possível, portanto, que se estipule que a resolução do contrato operar-se-á sobre a quota-parte do terreno e da parte construída, ainda que o adquirente tenha pago totalmente uma das partes ${ }^{208}$, o que se demonstra lógico, uma vez que a parte construída está intrinsecamente ligada à aquisição de fração ideal sobre o terreno.

Ressalte-se que há regras específicas para proteção da massa condominial na Lei $n^{\circ}$ 4.591/64, que estabelecem a realização de leilão extrajudicial em caso de inadimplência do adquirente, nos termos do art. 63 da Lei de Incorporação Imobiliária ${ }^{209}$.

Aludido artigo permite que o contrato defina, no caso de falta de pagamento de três prestações do preço da construção, o envio de notificação para purgação da mora no prazo de dez dias e, caso tal prazo seja descumprido, a resolução do contrato, ficando a Comissão de Representantes autorizada a efetuar leilão para venda, promessa de venda ou de cessão, ou a cessão da quota de terreno e da correspondente parte construída.

Para tanto, o parágrafo $5^{\circ}$ do artigo em questão determina que a Comissão de Representantes ficará investida de mandato irrevogável com poderes necessários para, em nome do condômino inadimplente, efetuar as citadas transações, podendo para este fim fixar preços, ajustar condições, sub-rogar o arrematante nos direitos e obrigações decorrentes do contrato de construção e da quota de terreno e construção; outorgar as competentes escrituras e contratos, receber preços, dar quitações; imitir o arrematante na posse do imóvel; transmitir domínio, direito e ação; responder pela evicção; receber citação, propor e variar de ações etc.

Ressalte-se que a necessidade de interpelação foi prevista anteriormente, como, por exemplo, no Decreto-Lei $n^{\circ} 745 / 69^{210}$, que, aplicando-se aos compromissos atinentes a imóvel loteado nos termos do Decreto-Lei n ${ }^{\circ} 58 / 37$, determina a prévia interpelação do devedor para purgação da mora, mesmo se houver cláusula resolutória expressa.

\footnotetext{
${ }^{208}$ CAMBLER, Everaldo Augusto. Responsabilidade civil na incorporação imobiliária, cit., p. 299.

${ }^{209}$ Tal procedimento tem por finalidade "manter o fluxo financeiro necessário ao regular andamento da obra" e consiste na venda particular de imóvel, feita pela Comissão de Representantes em caso de inadimplemento de condômino, em razão da prevalência do interesse coletivo, conforme CHALHUB, Melhim Namem. Negócio fiduciário, cit., p. 345.

${ }^{210}$ Conforme art. $1^{\circ}$ : "Nos contratos a que se refere o artigo 22 do Decreto-Lei $n^{\circ} 58$, de 10 de dezembro de 1937, ainda que deles conste cláusula resolutiva expressa, a constituição em mora do promissário comprador depende de prévia interpelação, judicial ou por intermédio do cartório de Registro de Títulos e Documentos, com quinze (15) dias de antecedência.”.
} 
Questão bastante controvertida é relativa às parcelas pagas pelo compromissário comprador em caso de resolução do contrato e à validade de cláusula que determina, no caso de falta de pagamento, a perda das importâncias pagas e das benfeitorias inseridas pelo compromissário comprador no imóvel, mais conhecida como cláusula de decaimento.

É certo que, havendo resolução do contrato, as partes devem retornar ao estado anterior, de forma que o imóvel prometido a venda deve ser devolvido ao alienante e o promitente adquirente deve obter restituição dos valores pagos.

Os art. 34 e 35 da Lei 6.766/79 211 e o parágrafo $1^{\circ}$ do art. 12 do Decreto-Lei $\mathrm{n}^{\circ}$ $58 / 37^{212}$ mencionam a hipótese de resolução, apenas fazendo referência à restituição do valor pago pelo compromissário comprador, sem definir se se trata de restituição integral ou não.

O art. 53 do Código de Defesa do Consumidor ${ }^{213}$ veda a perda total dos valores pagos pelo adquirente, em caso de resolução de contratos de compra e venda mediante pagamento em prestações, não vedando, contudo, a perda parcial de valores, a ser verificada caso a caso, em razão de eventual fruição do imóvel ou de sua valorização, bem como de prejuízos ocasionados pelo compromissário comprador ${ }^{214}$.

Sobre referido artigo, Cavalieri entende que a vedação de perda total das prestações pagas não pode impedir que o vendedor seja ressarcido pelas despesas e por

${ }^{211}$ Cuja redação é a seguinte: “Art. 34. Em qualquer caso de rescisão por inadimplemento do adquirente, as benfeitorias necessárias ou úteis por ele levadas a efeito no imóvel deverão ser indenizadas, sendo de nenhum efeito qualquer disposição contratual em contrário. Parágrafo único - Não serão indenizadas as benfeitorias feitas em desconformidade com o contrato ou com a lei."; e "Art. 35. Ocorrendo o cancelamento do registro por inadimplemento do contrato e tendo havido o pagamento de mais de $1 / 3$ (um terço) do preço ajustado, o Oficial do Registro de Imóveis mencionará este fato no ato do cancelamento e a quantia paga; somente será efetuado novo registro relativo ao mesmo lote, se for comprovada a restituição do valor pago pelo vendedor ao titular do registro cancelado, ou mediante depósito em dinheiro à sua disposição junto ao Registro de Imóveis. (...)".

212، $\$ 1^{\circ}$ Em caso de resolução, além de se devolverem as prestações recebidas, com juros convencionados ou os da lei, desde a data do pagamento, haverá, quando provada a má fé, direito à indenização de perdas e danos."

${ }^{213}$ "Nos contratos de compra e venda de móveis ou imóveis mediante pagamento em prestações, bem como nas alienações fiduciárias em garantia, consideram-se nulas de pleno direito as cláusulas que estabeleçam a perda total das prestações pagas em benefício do credor que, em razão do inadimplemento, pleitear a resolução do contrato e a retomada do produto alienado.".

${ }^{214}$ Nesse sentido, decisão do STJ, em 20.06.2006, no REsp 601008 / SP, tendo como Relator Ministro Aldir Passarinho Junior, da Quarta Turma: “(...) III. Ainda que por comum acordo, o desfazimento do contrato dá ao comprador o direito à restituição das parcelas pagas, porém não em sua integralidade, em face das despesas realizadas pela vendedora com corretagem, propaganda, administrativas e assemelhadas, sob pena de injustificada redução patrimonial em seu desfavor. Retenção fixada em parâmetro diverso pelo Tribunal a quo, mas que, na prática, resulta em valor muito próximo ao do critério adotado pelo STJ, inexistindo, pois, abusividade que justifique a intervenção desta Corte a respeito.”. 
danos que lhe forem acarretados em razão da resolução do contrato, inclusive gastos com corretagem, publicidade, aluguel pelo uso do imóvel pelo adquirente etc. ${ }^{215}$.

Com razão, devem ser avaliados, em cada caso, os prejuízos causados de uma parte à outra, para que os respectivos patrimônios não sofram acréscimo ou redução sem causa correspondente.

Tratando-se de contrato, é pertinente que as partes estipulem cláusula penal, tanto para hipóteses de mora quanto para de inadimplemento.

No tocante à cláusula penal, o Decreto-Lei 58/37, em seu art. 11 "f"216, e o art. 26, V, da Lei $6.766 / 79^{217}$, contêm previsão de limitação de cláusula penal no total de $10 \%$ do débito.

Assim, é possível que, a título de cláusula penal, haja perda de valores pagos, porém até o total de $10 \%$ do débito.

Para imóveis não loteados, não havendo disposição específica acerca do tema, deve-se verificar se a relação é de consumo ou não, sendo que o Código de Defesa do Consumidor, no art. 52, parágrafo $1^{0218}$, limita a multa a $2 \%$ no caso de inadimplemento de obrigações relativas a outorga de crédito ou concessão de financiamento.

Em caso de relação não considerada de consumo, cabe verificar o limite do art. 412 do Código Civil ${ }^{219}$, não podendo, assim, a cláusula penal ser superior ao valor da obrigação principal, e a possibilidade de o juiz reduzir a multa, conforme art. $413^{220}$.

Havendo previsão mais específica quanto a limite de cláusula penal, como as atinentes a imóveis loteados, esta deve prevalecer.

Em qualquer hipótese de resolução, entende-se que o incorporador deve restituir os valores pagos pelo adquirente, observada eventual cláusula penal e seus limites impostos por lei, devendo o incorporador, entretanto, ser recompensado pelos gastos que

${ }^{215}$ CAVALIERI FILHO, Sergio. Programa de direito do consumidor. São Paulo: Atlas, 2008. p. 226.

${ }^{216}$ Art. 11. Do compromisso de compra e venda a que se refere esta lei, contratado por instrumento público ou particular, constarão sempre as seguintes especificações: (...) f) cláusula penal não superior a $10 \%$ do débito, e só exigível no caso de intervenção judicial.

${ }^{217}$ Inciso que possui a seguinte redação: "V - taxa de juros incidentes sobre o débito em aberto e sobre as prestações vencidas e não pagas, bem como a cláusula penal, nunca excedente a 10\% (dez por cento) do débito e só exigível nos casos de intervenção judicial ou de mora superior a 3 (três) meses;".

218“" $1^{\circ}$ As multas de mora decorrentes do inadimplemento de obrigações no seu termo não poderão ser superiores a dois por cento do valor da prestação.".

219“"Art. 412. O valor da cominação imposta na cláusula penal não pode exceder o da obrigação principal.".

220“'Art. 413. A penalidade deve ser reduzida eqüitativamente pelo juiz se a obrigação principal tiver sido cumprida em parte, ou se o montante da penalidade for manifestamente excessivo, tendo-se em vista a natureza e a finalidade do negócio.". 
lhe forem causados em razão do inadimplemento, incluindo-se eventual valor arbitrado pelo uso do imóvel pelo adquirente, se for o caso ${ }^{221}$.

Não se pode deixar de mencionar que o Judiciário reconhece o direito de o próprio adquirente ingressar com ação visando à resolução do contrato em razão de seu inadimplemento $^{222}$, não obstante as regras constantes do Código Civil, no que se refere à possibilidade de resolução contratual.

Por fim, como mais uma obrigação do adquirente, cabe a este a contratação de seguro que garanta sua obrigação de pagamento em casos de morte e invalidez permanente do adquirente, em relação a financiamentos obtidos pelo adquirente no âmbito do SFI, nos termos do art. $5^{\circ}$, IV, da Lei $\mathrm{n}^{\mathrm{o}}$ 9.514/97 223 . Na ocorrência do sinistro, garante-se pagamento do saldo devedor do valor do imóvel ou do financiamento relativo à aquisição do imóvel.

\subsubsection{Recebimento da coisa}

Inicialmente, cabe mencionar que o art. 52 da Lei $n^{\circ} 4.591 / 64^{224}$ prevê que o adquirente só será imitido na posse da unidade se estiver adimplente. Caso contrário, o construtor, o condomínio ou o incorporador, conforme o caso e modalidade da incorporação, tem direito de retenção da unidade.

\footnotetext{
${ }^{221}$ Quanto ao percentual de retenção, veja-se o julgamento do REsp 187963/SP, em 19.03.09, da 4a Turma do Superior Tribunal de Justiça, tendo como Relator o Ministro Aldir Passarinho Jr., que definiu que a situação peculiar (não identificada responsabilidade da construtora, o comprador teve a posse precária do imóvel e nele empreendeu reforma parcial, alterando as características originais) ensejava a retenção de $50 \%$ dos valores pagos pelo adquirente.

${ }^{222}$ Como noticia Claudia Lima Marques, com base nas previsões do Código de Defesa do Consumidor de que o consumidor tem direito de escolher entre manter a relação ou resolvê-la, bem como de ter modificação de cláusulas excessivamente onerosas e a devolução de parcelas pagas: "o consumidor tem o direito de propor a ação de rescisão e restituição das importâncias pagas, mesmo que inadimplente. A jurisprudência do STJ, como EResp n ${ }^{\mathrm{o}}$ 59870/SP, $2^{\mathrm{a}}$ Turma, rel. Min. Barros, DJ. 9.12.02, tem sido sensível a esta necessidade subjetiva do consumidor, mesmo que já em estado de inadimplência, de conseguir rescindir os contratos cativos de longa duração, de forma a evitar sua ruína ou o superendividamento definitivo, em especial em contratos de compromisso de compra e venda de imóveis.” p. 295. Cite-se, ainda, julgamento do REsp 838516/RS, de 17.05.11, da $4^{\mathrm{a}}$ Turma, cujo relator foi Min. Luis Felipe Salomão. MARQUES, Claudia de Lima. Contratos no Código de Defesa do Consumidor: o novo regime das relações contratuais. 6. ed. São Paulo: Ed. Revista dos Tribunais, 2011. p. 70.

223،“Art. $5^{\circ}$ As operações de financiamento imobiliário em geral, no âmbito do SFI, serão livremente pactuadas pelas partes, observadas as seguintes condições essenciais: (...) IV - contratação, pelos tomadores de financiamento, de seguros contra os riscos de morte e invalidez permanente.”.

224“"Art. 52. Cada contratante da construção só será imitido na posse de sua unidade se estiver em dia com as obrigações assumidas, inclusive as relativas à construção exercendo o construtor e o condomínio até então, o direito de retenção sôbre a respectiva unidade; no caso do art. 43, êste direito será exercido pelo incorporador.".
} 
Ainda que o recebimento da coisa seja direito do adquirente, é também obrigação, que permite a efetiva transferência da propriedade da unidade autônoma devidamente construída.

O cumprimento dessa obrigação resvala na possibilidade de caracterização da mora creditoris, ou seja, mora do credor $^{225}$, uma vez que tão logo pronta e acabada a obra, abre-se a oportunidade para que o adquirente ateste que está recebendo a coisa como contratado, sendo relevante por caracterizar a imissão na posse do imóvel, gerando, posteriormente, a obrigação do adquirente de assumir pagamento de taxas condominiais e impostos.

É essencial que o adquirente faça a vistoria do bem entregue, ressalvando, expressamente, quaisquer defeitos ou irregularidades, de forma que não haja omissão de sua parte no recebimento da coisa.

Franco e Gondo, por exemplo, informam que, ainda que a lei brasileira seja silente nesse sentido, a atitude razoável por parte do adquirente, havendo irregularidade, é receber as chaves sob protesto, especificando-se todos os defeitos de construção e sua desconformidade com o memorial descritivo ou o contrato ${ }^{226}$.

Trata-se de medida salutar para identificação de irregularidades, de forma a se constituir, posteriormente, o incumprimento da obrigação do incorporador de entregar o imóvel adequadamente construído, conforme normas e projetos atinentes ${ }^{227}$.

Não obstante, as regras que permeiam os vícios da coisa e o cumprimento adequado de obrigações e mesmo as regras protetivas dos consumidores podem assegurar os direitos do adquirente, independentemente da ressalva expressa de qualquer irregularidade, como será analisado.

\footnotetext{
${ }^{225} \mathrm{O}$ art. 400 do Código Civil faz referência à consequência da mora do credor, a ver: "Art. 400. A mora do credor subtrai o devedor isento de dolo à responsabilidade pela conservação da coisa, obriga o credor a ressarcir as despesas empregadas em conservá-la, e sujeita-o a recebê-la pela estimação mais favorável ao devedor, se o seu valor oscilar entre o dia estabelecido para o pagamento e o da sua efetivação."

${ }^{226} \mathrm{Tal}$ constatação é resultado de comparação com a lei francesa, que, segundo os autores, prevê que nesses casos o juiz, mediante provocação do interessado, deve designar perito para verificar se o imóvel apresenta condições mínimas de habitabilidade e, em caso negativo, pode o adquirente receber as chaves e futuramente propor ação adequada (FRANCO, João Nascimento; GONDO Nisske. Incorporaçães imobiliárias, cit., p. 125).

${ }^{227} \mathrm{Na}$ lição de Chalhub, "Havendo reparos a realizar, a edificação e as unidades são, em regra, recebidas com ressalvas, para que o incorporador corrija as irregularidades.". CHALHUB, Melhim Namem. Da incorporação imobiliária, cit., p. 159.
} 


\section{APLICAÇÃO DO CÓDIGO DE DEFESA DO CONSUMIDOR}

\subsection{O Código de Defesa do Consumidor}

Transformações no conceito e na importância da vontade ocorreram durante a história do Direito, sendo que foi na época da Revolução Francesa que o dogma da vontade $^{228}$ atingiu seu ápice, com base no fundamento na liberdade e na igualdade, no individualismo e no conceito de propriedade ${ }^{229}$.

No século XX, a autonomia da vontade passou a ceder lugar à autonomia privada, uma vez que a extrema igualdade entre as partes não se confirmou na prática ${ }^{230}$, verificando-se desigualdade em diversas relações contratuais, inclusive na esfera consumerista, tendo em vista os avanços da sociedade moderna, que afetaram sobremaneira o consumo e justificaram, nesse âmbito, a imposição das condições contratuais pelos fornecedores ${ }^{231}$.

A liberdade começou, então, a sofrer interferências pelo Estado, de forma a se estabelecer um equilíbrio contratual nos casos em que este não se verificava. Tais interferências alcançaram a esfera privada e a ordem econômica, o que se verifica, inclusive, da análise da Constituição Federal ${ }^{232}$.

Além da limitação à autonomia, outros princípios passaram a ser levados em consideração no que se refere aos contratos, tais como os princípios da boa-fé e da função

\footnotetext{
${ }^{228}$ A autonomia da vontade definia a plena liberdade de manifestação de vontade, e, nessa acepção, os indivíduos poderiam se autoregrar, uma vez que eram, em teoria, todos iguais.

${ }^{229}$ Segundo Marcos Bernardes de Mello, o conceito de negócio jurídico foi, assim, construído sob a inspiração ideológica do Estado liberal, cuja característica principal era a preservação da liberdade individual. Por isso, concebeu-se o negócio jurídico como instrumento de realização da vontade individual, respaldando uma liberdade contratual que se queria praticamente sem limites. MELLO, Marcos Bernardes de. Teoria do fato jurídico: plano da existência. 12. ed. São Paulo: Saraiva, 2003. p. 162.

${ }^{230}$ Nesse sentido, Vera Helena de Mello Franco menciona que "a igualdade formal, até aceita, passou, na realidade, a encobrir uma desigualdade substancial." (FRANCO, Vera Helena de Mello. Os contratos empresariais e seu tratamento após o advento do Código Civil de 2002. Revista de Direito Mercantil, Industrial, Econômico e Financeiro, São Paulo, v. 48, n. 151/152, p. 22-46, jan./dez. 2009).

${ }^{231}$ Conforme Claudia Lima Marques, "Os métodos de contratação em massa, ou estandardizados, predominam em quase todas as relações contratuais entre empresas e consumidores.”. MARQUES, Claudia de Lima. Contratos no Código de Defesa do Consumidor: o novo regime das relações contratuais, cit., p. 70.

${ }^{232} \mathrm{O}$ art. $1^{\circ}$, III, define como fundamento da República a dignidade da pessoa humana, sendo que qualquer avença entre particulares, no âmbito da autonomia privada, deve assegurar a dignidade dos contratantes; o inciso IV deste artigo define como fundamento, também, os valores sociais do trabalho e da livre iniciativa; o art. 170 define princípios limitantes da atuação dos cidadãos quanto à ordem econômica, mencionando a função social da propriedade.
} 
social do contrato, que se somaram aos princípios clássicos, como a força obrigatória dos contratos e a relatividade do contrato.

A proteção conferida pelo Estado à parte tida como mais fraca em uma relação de consumo foi assegurada pela Constituição Federal de $88^{233}$, mas realizada, especialmente, pela Lei $n^{\circ} 8.078 / 90$, que instituiu o Código de Defesa do Consumidor e trouxe definições importantes no sentido de intervir nessas relações para que se possa alcançar a igualdade nas contratações ${ }^{234}$.

Ressalte-se que a proteção do mais fraco não pode ser exacerbada, a ponto de fragilizar a atividade econômica da outra parte ${ }^{235}$, devendo-se buscar, de fato, o equilíbrio.

A proteção aos consumidores foi cogitada em todas as fases da relação mantida entre as partes, inclusive na publicidade, sendo que o fornecedor deve observar integralmente $\mathrm{o}$ conteúdo normativo atinente às relações de consumo. Exemplificativamente, as disposições quanto a publicidade e fornecimento de informações relevantes e claras que importem ao consumidor, as relativas às práticas consideradas abusivas, as regras atinentes ao contrato de adesão e todos os demais direitos dos consumidores e obrigações dos fornecedores.

Trata-se, assim, de normativo que estipula benefícios aos consumidores, em razão da alegada hipossuficiência fática, visando ao reequilíbrio da relação entre parte considerada frágil e parte estruturada para agir no mercado de consumo.

$\mathrm{Na}$ Itália, assim como em outros países da Europa, referida busca ensejou a criação de normas consumeristas específicas ${ }^{236}$, não havendo em tais normas, contudo,

\footnotetext{
${ }^{233}$ No tocante ao direito do consumidor, este foi inserido explicitamente em nosso ordenamento jurídico apenas com a promulgação da Constituição Federal de 1988, alcançando categoria de direito individual e coletivo, conforme art. 5', XXXII: "XXXII - o Estado promoverá, na forma da lei, a defesa do consumidor". Nossa Constituição, ainda, erigiu a defesa do consumidor à categoria de princípio geral da atividade econômica, de acordo com o art. 170, V. Oportunamente, cumpre ressaltar que, apesar de ter sido a Constituição Federal de 1988 a propulsora da defesa do direito do consumidor, já existiam algumas normas que direta ou indiretamente se relacionavam ao consumidor, como, por exemplo, a Lei $\mathrm{n}^{\circ}$ 1521/51, a chamada Lei de Economia Popular, além da Lei Delegada n ${ }^{\circ}$ 04/62 e a Lei da Ação Civil Pública, nº 7347/85.

${ }^{234}$ GARCIA, Leonardo de Medeiros. Código comentado de direito do consumidor. Rio de Janeiro: Ed. Impetus, 2005. p. 3.

${ }^{235}$ Esse é um dos objetivos da Politica Nacional de Relações de Consumo, conforme art. $4^{\text {o }}$, III, do Código de Defesa do Consumidor: "III - harmonização dos interesses dos participantes das relações de consumo e compatibilização da proteção do consumidor com a necessidade de desenvolvimento econômico e tecnológico, de modo a viabilizar os princípios nos quais se funda a ordem econômica (art. 170, da Constituição Federal), sempre com base na boa-fé e equilíbrio nas relações entre consumidores e fornecedores;".

${ }^{236}$ Como cita Mezzasoma, Lorenzo: “...con una scelta che si inquadra in un processo ricodificatorio riguardante numerosi settori, scelta diversa da quella operata, generalmente, a livello europeo, ove si è preferito novellare il codice civile, od emanare un vero e proprio testo unico di settore, e che ha rari
} 
disposições claras que prevejam a questão da negociação imobiliária em geral ou acerca da aquisição de imóveis em construção.

\subsection{A relação de consumo}

Para definição de tal relação, compete avaliar os conceitos trazidos pelo Código de Defesa do Consumidor para sua configuração, de forma a verificar sua incidência a contratos como o da incorporação imobiliária.

O Código de Defesa do Consumidor traz a definição de consumidor no art. $2^{\text {o237 }}$, sendo todo aquele que adquire bens e serviços como destinatário final.

O conceito legal de consumidor refere-se, principalmente, à destinação final do produto, devendo-se interpretar o conceito de destinação final.

A corrente chamada finalista entende que deve ser feita uma interpretação restrita do art. $2^{\circ}$, estabelecendo que consumidor será somente aquele que de fato e sob o ponto de vista econômico retira bem ou serviço do mercado de consumo, sendo "destinatário fático e econômico",238.

Referida corrente não abrange, portanto, o consumidor profissional, que utiliza o bem ou serviço na cadeia de produção de sua própria atividade, nem aquele que adquire para revenda.

Em contrapartida, a corrente maximalista pretende ampliar a adoção de regras protetivas para todos os agentes do mercado de consumo, bastando, para tanto, que o bem ou serviço seja retirado de fato do mercado ${ }^{239}$.

precedenti, tra cui spicca quello francese, il codice di consumo riunisce, in 146 articoli, ben 21 provvedimenti, raccogliendo in unico testo normativo una serie di leggi speciali, spesso non coordinate tra di loro e riconducibili a diverse epoche storiche, che ruotano intorno all'atto economico del consumo o, meglio, ai processi di acquisto e consumo, nella consapevolezza che, come già è stato evidenziato, lo stesso attributo di consumatore va ricondotto al contenuto dell'atto posto in essere, evocando, tale attributo, il protagonista dell'azione mirata ad un atto qualificato sul piano finalístico.". MEZZASOMA, Lorenzo. Il "Consumatore" acquirente di immobili da costruire fra diritto al risparmio e diritto all abitazione, cit., p. 33-34.

237 “Art. $2^{\circ}$ - Consumidor é toda pessoa física ou jurídica que adquire ou utiliza produto ou serviço como destinatário final.".

${ }^{238}$ Vide MARQUES, Claudia de Lima. Contratos no Código de Defesa do Consumidor: o novo regime das relações contratuais, cit., p. 305.

${ }^{239}$ BESSA, Leonardo Roscoe. Vícios dos produtos: paralelo entre o CDC e o Código Civil. In: PFEIFFER, Roberto Augusto Castellanos; PASQUALOTTO, Adalberto (Coords.). Código de Defesa do Consumidor e $o$ Código Civil de 2002: convergências e assimetrias. São Paulo: Ed. Revista dos Tribunais, 2005. p. 284. 
Há entendimento, ainda, que vincula o consumidor a outro aspecto, qual seja, o da chamada hipossuficiência do consumidor ${ }^{240}$, sendo vertente da primeira teoria. Assim, seria aplicável o Código de Defesa do Consumidor a certos consumidores profissionais, desde que verificada a chamada vulnerabilidade técnica, jurídica, econômica ou, ainda, a fática, que, como cita Cláudia Lima Marques, é aquela em que a outra parte exerce posição de monopólio, fático ou jurídico, por seu grande poder econômico ou em razão da essencialidade do serviço ${ }^{241}$.

Mais adequada a tese que considera consumidor aquele que retira do mercado um produto ou serviço definitivamente, sem, contudo, utilizá-lo diretamente em sua atividade profissional, em sua própria cadeia de produção, podendo admitir-se como consumidor, contudo, aquele que adquire o produto ou serviço, ainda que para uso indireto em sua atividade profissional, mas que se apresenta comprovadamente vulnerável no momento da contratação ${ }^{242}$.

Ressalte-se a definição de fornecedor trazida pelo artigo $3^{\circ}$ do Código de Defesa do Consumidor ${ }^{243}$, que abrange as atividades de construção e de comercialização de produtos ou prestação de serviços, entre outras.

Ante a leitura do $\S 1^{\circ}$ do citado artigo ${ }^{244}$, também se afirma a sua abrangência no que se refere ao objeto da incorporação imobiliária, uma vez que se refere como produto qualquer bem imóvel.

\footnotetext{
${ }^{240}$ Conforme José Brito Filomeno, em GRINOVER, Ada Pellegrini et al. Código Brasileiro de Defesa do Consumidor: comentado pelos autores do anteprojeto. 7. ed. Rio de Janeiro: Forense Universitária, 2001. p. 28, que assim dispõe: "O traço marcante da conceituação de "consumidor”, no nosso entender, está na perspectiva que se deve adotar, ou seja, no sentido de se o considerar como hipossuficiente ou vulnerável...", afirmando, ainda, entendimento de que pessoas jurídicas não poderiam ser consumidoras por lhes faltar a hipossuficiência. Ainda, Cláudia Lima Marques menciona côo ma terceira teoria, subdivisão da teoria finalista, que passa a considerar a vulnerabilidade ou hipossuficiencia do consumidor, definindo, ao final, que a vulnerabilidade é presumida para pessoa física, consumidor não-profissional, devendo-se considerar profissionais consumidores como exceção. MARQUES, Claudia de Lima. Contratos no Código de Defesa do Consumidor: o novo regime das relações contratuais, cit., p. 307-325 e 406.

${ }^{241}$ MARQUES, Claudia de Lima. Contratos no Código de Defesa do Consumidor: o novo regime das relações contratuais, cit., p. 330.

${ }^{242}$ Conforme exposto em recente decisão do TJ/MG: "INDENIZAÇÃO - VÍCIO REDIBITÓRIO - DANOS MATERIAIS E MORAIS - APLICAÇÃO DO CDC - TEORIA MAXIMALISTA - INVERSÃO DO ÔNUS DA PROVA - DEFEITO EM PRODUTO - MAU USO - NÃO COMPROVAÇÃO - RECURSO IMPROVIDO. Seguindo o entendimento já manifestado pelo STJ, entendo se deva adotar a exegese extensiva proposta pela corrente maximalista, de maneira a conferir o tratamento protecionista aos sujeitos que, conquanto não utilizem o produto para consumo pessoal, o fazem para viabilizar a atividade desenvolvida e gozam de notória vulnerabilidade em face do fabricante. (...)”. Apelação Cível 1.0106.12.000668-4/001, Rel. Des.(a) Evangelina Castilho Duarte, $14^{a}$ Câmara Cível, julg. em 14/08/2013.

${ }^{243}$ "Fornecedor é toda pessoa física ou jurídica, pública ou privada, nacional ou estrangeira, bem como os entes despersonalizados, que desenvolvem atividades de produção, montagem, criação, construção, transformação, importação, exportação, distribuição ou comercialização de produtos ou prestação de serviços." (grifos da autora)

244"Produto é qualquer bem, móvel ou imóvel, material ou imaterial."
} 
No $\S 2^{\circ}$ do mesmo dispositivo ${ }^{245}$, há ratificação da abrangência em razão da definição de serviço.

Com base nos artigos constantes do Código de Defesa do Consumidor, parece não haver dúvidas ${ }^{246}$ de que a atividade do incorporador e a venda de unidades autônomas, como bens imóveis, estão por ele abrangidas, não se podendo negar sua incidência, desde que o adquirente seja considerado consumidor e haja habitualidade do fornecedor ${ }^{247}$.

Paulo Scartezzini inclui como consumidor os que adquirem ou utilizam algo de forma pessoal e não profissional, e afirma que “(...) em qualquer aquisição de apartamentos de construtoras ou incorporador aplica-se o Código de Defesa do Consumidor", justificando tal posicionamento pela inclusão expressa de bens imóveis como produto ${ }^{248}$.

No entanto, muitas vezes a aquisição no sistema de incorporação imobiliária é realizada com a finalidade de especulação e de atuação de investidores, que adquirem os imóveis para posterior "revenda", de forma a obter lucro.

Deve-se indagar, pois, se a pessoa física que adquire imóvel pensando na sua venda posterior, para obtenção de lucro, é ou não considerada consumidor.

Na hipótese de pessoa física adquirente, ainda que com o objetivo de revenda posterior, está caracterizada a relação de consumo, desde que a pretensão de lucro seja autônoma e não se refira a atividade profissional habitual.

Ressalte-se, ainda, que o art. 29 do Código de Defesa do Consumidor menciona o consumidor equiparado. Ainda que haja revenda, o adquirente posterior poderia estar abarcado na concepção trazida pelo citado artigo.

Tem-se que, se a aquisição de imóvel for para fins de moradia, o que acontece mais frequentemente na incorporação imobiliária, não se poderá negar a incidência do Código de Defesa do Consumidor.

\footnotetext{
245 "Serviço é qualquer atividade fornecida no mercado de consumo, mediante remuneração (...), salvo as decorrentes das relações de caráter trabalhista.".

${ }^{246}$ Cavalieri entende da mesma forma: “(...) não há como negar que o incorporador/construtor é um fornecedor de produtos ou serviços, à luz dos conceitos claros e objetivos constantes do art. $3^{\circ}$ do Código de Defesa do Consumidor. (...) E sendo essa obrigação assumida com alguém que se posiciona no último elo do ciclo produtivo, alguém que adquire essa unidade imobiliária como destinatário final, para fazer dela a sua moradia e da sua família, está formada a relação de consumo que torna impositiva a aplicação do Código de Defesa do Consumidor..." (CAVALIERI FILHO, Sergio. Programa de direito do consumidor, cit., p. 224).

${ }^{247}$ Como expõe Bessa, a doutrina exige tal requisito para caracterizar a figura do fornecedor. BESSA, Leonardo Roscoe. Vícios dos produtos: paralelo entre o CDC e o Código Civil, cit., p. 286.

${ }^{248}$ GUIMARÃES, Paulo Jorge Scartezzini. Vícios do produto e do serviço por qualidade, quantidade $e$ insegurança: cumprimento imperfeito do contrato. 2. ed. São Paulo: Ed. Revista dos Tribunais, 2007. p. 75 e 79.
} 
Caso a aquisição seja por pessoa física para uso como sede de sua empresa individual, por exemplo, igualmente deve haver relação de consumo, ainda que se possa afirmar que o imóvel será utilizado na atividade profissional.

Se se tratar de aquisição por pessoa jurídica no âmbito de sua atividade negocial, como no caso de aquisição de imóvel por fundo de investimento, contudo, não deve haver aplicação do Código de Defesa do Consumidor.

Apesar da diversidade de entendimentos e hipóteses, depreende-se que é perfeitamente aceitável a aplicação do Código de Defesa do Consumidor na maioria das situações de aquisição de imóvel na incorporação imobiliária.

\subsection{Cotejo entre a Lei $n^{0}$ 4.591/64, o Código Civil e o Código de Defesa do Consumidor}

Embora admitida a caracterização da relação entre incorporador e adquirente como relação de consumo, não se pode desmesuradamente prever a aplicação do Código de Defesa do Consumidor em detrimento de outras normas, como o Código Civil e a lei própria das incorporações imobiliárias.

Ainda que o Código de Defesa do Consumidor seja pioneiro, no Brasil, quanto à regulação específica e abrangente de uma relação marcada pelo desequilíbrio, podemos afirmar que o atual Código Civil refletiu, igualmente, os novos paradigmas contratuais, definindo a boa-fé objetiva ${ }^{249}$, a função social do contrato ${ }^{250}$ e da propriedade, e o princípio do equilíbrio econômico, que se estende por diversos artigos do Código, tais como o art.

\footnotetext{
${ }^{249}$ O Código Civil de 2002 prevê expressamente a aplicação do princípio da boa-fé objetiva às relações contratuais comuns, independentemente de qualquer vulnerabilidade presumida ou demonstrada, como pode ser necessário em relação ao Código de Defesa do Consumidor, conforme TEPEDINO, Gustavo; SCHREIBER, Anderson. A boa-fé objetiva no Código de Defesa do Consumidor e no novo Código Civil. In: TEPEDINO, Gustavo (Org.). Obrigações: estudos na perspectiva civil-constitucional. Rio de Janeiro: Renovar, 2005. p. 29-44. Ressalte-se que o artigo 422 de aludido Código Civil estabelece que as partes são obrigadas a guardar, assim na conclusão do contrato como em sua execução, o princípio de probidade e boa-fé.

${ }^{250}$ A função social do contrato é inovação trazida pelo Código Civil de 2002, que, em seu artigo 421, assim definiu: "A liberdade de contratar será exercida em razão e nos limites da função social do contrato.". Representa a tendência surgida no século XX de intervenção nos contratos e, especialmente, de limitação à autonomia das partes.
} 
157 que trata o instituto da lesão e os arts. 489 a 480, que tratam da resolução do contrato por onerosidade excessiva ${ }^{251}$.

Assim, o Código Civil possui ideologia similar à do Código de Defesa do Consumidor $^{252}$, sendo aquele, entretanto, regulação para todas as relações civis. Já o Código de Defesa do Consumidor é "sobreestrutura jurídica multidisciplinar, normas de sobredireito aplicáveis em todos os ramos do Direito (...) onde ocorrerem relações de consumo"253.

Chalhub entende que, em relação ao Código Civil, o Código de Defesa do Consumidor é lei especial, por tratar especificamente de relações consumeristas, devendo ser aplicado de forma consistente, ressaltando que, para ele, não há revogação das regras daquele Código ${ }^{254}$.

Considerando não haver revogação de uma lei ou de outra, as diferentes normas, se em contradição, devem ser devidamente analisadas, havendo entendimento, inclusive, de que o diálogo das fontes é pela "aplicação harmônica e sistemática das leis especiais e gerais a favor dos direitos fundamenais e dos valores mais elevados, sociais e públicos, e, sendo o direito do consumidor fundamental, se o Código Civil for mais favorável ao consumidor do que o Código de Defesa do Consumidor ${ }^{255}$, este, como lei especial, não deve limitar a aplicação da lei geral, com base no art. $7^{\circ}$ do Código de Defesa do Consumidor"256.

Apesar de pertinente a ideologia de aplicação harmônica das normas, que assegura a proteção do consumidor ao colocá-lo em pé de igualdade com o fornecedor, parece

\footnotetext{
${ }^{251}$ Para maiores explanações, ver CAVALIERI FILHO, Sergio. Programa de direito do consumidor, cit., p. $98-110$.

${ }^{252}$ Veja-se Enunciado 167 da III Jornada de Direito Civil: “Arts. 421 a 424: Com o advento do Código Civil de 2002, houve forte aproximação principiológica entre esse Código e o Código de Defesa do Consumidor, no que respeita à regulação contratual, uma vez que ambos são incorporadores de uma nova teoria geral dos contratos.".

${ }^{253}$ CAVALIERI FILHO, Sergio. Programa de direito do consumidor, cit., p. 224.

${ }^{254}$ CHALHUB, Melhim Namem. Negócio fiduciário, cit., p. 301. Similar entendimento é esposado por Humberto Theodoro Junior: "O Código Civil e o Código de Defesa do Consumidor atuam sobre universos distintos. O primeiro é uma lei geral e o segundo uma lei especial.”. THEODORO JÚNIOR, Humberto. Direitos do consumidor: a busca de um ponto de equilíbrio entre as garantias do Código de Defesa do Consumidor e os princípios gerais do direito civil e do direito processual civil. 7. ed. Rio de Janeiro: Forense, 2011. p. 284.

${ }^{255}$ Entendimento diverso de Lorenzo Mezzasoma, que, em relação ao direito italiano, menciona que só é possível aplicar o Código Civil se o Código de Defesa do Consumidor (Lei 210/04) não possuir regra adequada para regular o caso em questão. P. 35. Não obstante, Antonio Cilento entende de outra forma, devendo haver concorrência das normas no caso de o adquirente ser considerado também consumidor, conforme definição daquele Código de Defesa do Consumidor. L'acquisto di immobili in costruzione tra rischio econômico e tutela della persona, cit., p. 163.

${ }^{256}$ MARQUES, Claudia de Lima. Contratos no Código de Defesa do Consumidor: o novo regime das relações contratuais, cit., p. 729 e 614 e 1246.
} 
desarrazoada a busca incansável da melhor norma aplicável, sendo importante, em nosso entendimento, que se busque a norma mais específica.

Assim, as leis mais específicas que o Código de Defesa do Consumidor, como a Lei $n^{\circ} 9.514 / 97$ e a própria Lei $n^{\circ} 4.591 / 64$, devem prevalecer sobre o Código de Defesa do Consumidor, naquilo que é específico do objeto tratado nessas leis ${ }^{257}$.

A Lei $\mathrm{n}^{\circ}$ 4.591/64, editada quase trinta anos antes do Código de Defesa do Consumidor, tem o mesmo objetivo deste, que é criar meios de proteger o mais fraco nessa relação, motivo pelo qual não se pode cogitar da necessidade de aplicação de aludido Código de forma que haja, de fato, proteção dos adquirentes.

Não podemos olvidar, ainda, que a lei em questão foi concebida, desde sua origem, para ser o regramento de proteção dos adquirentes de imóveis na incorporação imobiliária, tendo sido alterada, inclusive, para se assegurar maior proteção em casos, por exemplo, de insolvência e falência do incorporador.

Veja-se que a lei em questão regula integralmente a atividade do incorporador e dita as regras atinentes à incorporação, definindo, inclusive, o próprio conteúdo do contrato ${ }^{258}$.

Exemplificativamente, tal lei dispõe sobre a publicidade do empreendimento, com o registro do memorial de incorporação, sobre a obrigação de entregar as unidades autônomas prontas e dar andamento às obras, definindo-se sanções civis e penais contra o incorporador, além da previsão de atuação dos adquirentes por meio da Assembleia e da Comissão de Representantes, entre outras diversas condições que protegem o adquirente.

O conteúdo da lei em questão é voltado às especificidades do contrato de incorporação imobiliária, que depende tanto da segurança aos adquirentes quanto ao incorporador e ao mercado imobiliário no geral. Por esse motivo, é importante que as regras ali contidas, desde que não venham a ferir as normas de ordem pública, sejam devidamente observadas, de modo que os pilares básicos da incorporação imobiliária sejam reforçados.

Corroborando entendimento de que à incorporação imobiliária devem ser aplicadas suas regras próprias, decisão do Superior Tribunal de Justiça, que deu

\footnotetext{
${ }^{257}$ CHALHUB, Melhim Namem. Negócio fiduciário, cit., p. 301.

${ }^{258}$ Nas palavras de Chalhub, a lei “(...) regulamenta toda a evolução do processo contratual, desde a fase précontratual, na qual está presente a obrigatoriedade de prévia exibição dos elementos essenciais do contrato, por meio do Memorial de Incorporação..., passando por todo o curso da execução do contrato e até extrapolando a fase da extinção do contrato, quando define a responsabilidade civil do incorporador.". ( $D a$ incorporação imobiliária, cit., p. 279).
} 
provimento a recurso especial, determinando o retorno dos autos ao Tribunal de origem a fim de que se proferisse nova decisão suficientemente fundamentada:

Verifica-se, assim, que o Tribunal de origem foi extremamente genérico ao julgar a apelação da recorrente, sem analisar seus argumentos acerca da aplicação dos dispositivos da Lei 4.591/64 à hipótese dos autos, notadamente aqueles relativos à possibilidade de revisão do orçamento inicial da construção a preço de custo, conforme contratado entre as partes. Com efeito, ainda que fosse para refutá-los, diante da sua importância para a resolução da controvérsia, o TJ/CE deveria ter analisado os argumentos da recorrente e explicitado as razões pela quais entendeu aplicável unicamente o CDC em detrimento dos dispositivos específicos da Lei 4.591/64.

(STJ - Recurso Especial no 1.151.728 - CE (2009/0150540-7), Rel. Min. Nancy Andrighi, julg. em 25/09/12)

Veja-se, ainda, trecho da decisão do Resp 800036, de relatoria do Min. Ruy Rosado de Aguiar Junior, previamente à vigência do Código Civil de 2002, que menciona que o Código de Defesa do Consumidor define princípios gerais do sistema civil, a saber:

[...] o contrato de incorporação continua regido pela lei que lhe é própria, mas os princípios gerais são os mesmos do sistema civil, entre eles os do CODECON...

A lei especial das incorporações atende a seu escopo de proteção, sem, contudo, desestimular as atividades produtivas, estando de acordo com a política relativa ao direito do consumidor, que defende, justamente, a proteção alinhada ao estímulo produtivo.

Dessa forma, pertinente a tese de prevalência das condições previstas na Lei $n^{\circ}$ 4.591/64, por já possuir em seu escopo a promoção do equilíbrio na relação mantida entre adquirente e incorporador, além de refletir a lei a lógica da atividade econômica envolvida na incorporação imobiliária.

Apesar disso, não se pode negar que há princípios gerais constantes do Código de Defesa do Consumidor que orientam a relação entre adquirente e incorporador, quando se tratar de relação de consumo, como o direito à informação, a vedação à publicidade enganosa e às práticas e cláusulas abusivas ${ }^{259}$.

\footnotetext{
${ }^{259}$ Humberto Theodoro Junior defende tal entendimento: “(...) a incidência da proteção conferida pelo Código do Consumidor na incorporação imobiliária se manifesta contra as práticas abusivas desde a fase précontratual, prossegue no estágio contratual e se estende pelo período pós-contratual.", de forma que o incorporador responde por abusos e por danos materiais e morais que acarretem ao consumidor. THEODORO JÚNIOR, Humberto. Direitos do consumidor: a busca de um ponto de equilíbrio entre as garantias do Código de Defesa do Consumidor e os princípios gerais do direito civil e do direito processual civil, cit., p. 278.
} 
Assim, deve o julgador buscar a aplicação das normas mais específicas, ainda que possa utilizar outras para robustecer os direitos dos adquirentes, sem se olvidar da natureza de ordem pública das normas do Código de Defesa do Consumidor. 


\section{INADIMPLEMENTO E RESPONSABILIDADE}

\subsection{Obrigação, mora e inadimplemento}

Não é possível atingir o objetivo deste trabalho sem que se analise, de forma não exaustiva, conceitos clássicos do Direito das Obrigações, avaliando de forma geral suas consequências.

\subsubsection{Obrigação}

Inicialmente, deve-se ter em mente o conceito da obrigação como processo, pelo qual "tenciona-se, justamente, sublinhar o caráter dinâmico da relação obrigacional, formada por uma série de atos que se ligam entre si com interdependência, orientados a certo fim., ${ }^{, 60}$.

O fim natural da obrigação é seu cumprimento, de forma a liberar o devedor e a satisfazer os interesses do credor ${ }^{261}$, e o seu descumprimento é uma anomalia, que justifica maior cuidado, pelo legislador, na sua determinação e na de suas consequências.

Assim, o adimplemento é a forma mais comum de liberação do devedor, sendo que sua importância deve ser aferida segundo critérios objetivos fundados na equivalência entre a prestação e a contraprestação ${ }^{262}$.

\footnotetext{
${ }^{260}$ Larenz, Karl. Derecho de Obligaciones, t. 1, Madrid: Editorial Revista de Derecho Privado, 1958, p. 38, apud TERRA, Aline de Miranda Valverde. Inadimplemento anterior ao termo. Rio de Janeiro: Renovar, 2009. p. 21.

${ }^{261}$ Conforme Araken de Assis, “(...) pode-se dizer que a obrigação vive para morrer por intermédio do adimplemento”. ASSIS, Araken de. Resolução do contrato por inadimplemento. 5. ed. São Paulo: Ed. Revista dos Tribunais, 2013. p. 97.

${ }^{262}$ Conforme AGUIAR JÚNIOR, Ruy Rosado de. Extinção dos contratos por incumprimento do devedor: Resolução - de acordo com o novo Código Civil, cit., p. 136.
} 


\subsubsection{Mora}

Há, comumente, segregação dos conceitos de mora e inadimplemento ${ }^{263}$.

Como regra básica, o devedor deve cumprir sua obrigação no tempo, lugar e forma convencionados, nos termos do art. 394 do Código Civil ${ }^{264}$.

Segundo Ruy Rosado, mora é o não-pagamento culposo no tempo, lugar e forma devidos $^{265}$, como trata o artigo acima indicado, compreendendo a inexistência de prestação, a prestação tardia, a efetuada fora do lugar adequado ou sem a forma prevista, sem se mencionar o modo como é prestada ${ }^{266}$.

Para caracterização da mora, exige-se a culpa ${ }^{267}$, sendo imprescindível fato ou omissão imputável ao devedor ${ }^{268}$, com exclusão, pois, de casos de descumprimento decorrentes de força maior ou caso fortuito ${ }^{269}$.

A configuração da mora pode surgir do simples atraso, em razão do preceito do “dies interpellat pro homine" 270 , que define que, não cumprida a obrigação no prazo convencionado, desde já passa a produzir efeitos da mora, por sua presunção.

\footnotetext{
${ }^{263} \mathrm{Na}$ doutrina, diversas denominações são utilizadas, havendo menção, por exemplo, a mora, inadimplemento, adimplemento, incumprimento, não cumprimento, descumprimento etc. Em resumo, podemos afirmar que todas as denominações refletem que a obrigação deixou de ser efetuada nos termos adequados, conforme lição de Mário Júlio de Almeida Costa, em Direito das obrigações. 4. ed. Coimbra: Coimbra Ed., 1984. p. 729. Para fins deste trabalho, trataremos do inadimplemento relativo como mora e do inadimplemento absoluto como inadimplemento, sendo que é absoluto quando a obrigação não foi e não poderá ser cumprida, ressaltando-se, ainda, que o inadimplemento absoluto pode ser dividido em total e em parcial, sendo que neste caso a obrigação é cumprida parcialmente, ou seja, algo foi entregue, mas não completamente, conforme lição de Assis, Araken de de Assis, Resolução do contrato por inadimplemento, cit., p. 85-86.

264،Art. 394. Considera-se em mora o devedor que não efetuar o pagamento e o credor que não quiser recebêlo no tempo, lugar e forma que a lei ou a convenção estabelecer."

${ }^{265}$ Semelhante definição é a de Limongi França: "mora é a inexecução culposa da obrigação (mora debitoris), bem como a recusa de recebè-la (mora creditoris) no tempo, lugar e forma determinados". FRANÇA, Rubens Limongi. Teoria e prática da cláusula penal. São Paulo: Saraiva, 1988. p. 188.

${ }^{266}$ Conforme AGUIAR JÚNIOR, Ruy Rosado de. Extinção dos contratos por incumprimento do devedor: Resolução - de acordo com o novo Código Civil, cit., p. 119 e 124.

${ }^{267}$ Tanto no sentido lato, que abrange o dolo, quanto no sentido estrito, caracterizada por negligência, imprudência ou imperícia.

${ }^{268}$ Para que haja mora, impõe-se a culpa do devedor, havendo críticas ao conteúdo do art. 396 do Código Civil, que assim dispõe: "Não havendo fato ou omissão imputável ao devedor, não incorre este em mora". A crítica justifica-se, pois só se pode cogitar da mora havendo fato ou omissão imputável ao devedor, sendo que sem tal imputabilidade mora não haverá.

${ }^{269}$ De acordo com o art. 393 do Código Civil, o devedor só responde por caso fortuito ou força maior se tiver se obrigado expressamente a isso: "O devedor não responde pelos prejuízos resultantes de caso fortuito ou força maior, se expressamente não se houver por eles responsabilizado.”.

${ }^{270} \mathrm{Em}$ relação ao assunto, ressaltamos a existência da mora ex re, que, segundo Agostinho Alvim, surge em caso de obrigação positiva e líquida e que haja termo, tão logo o descumprimento ocorra em razão do prazo estipulado para cumprimento, em Da inexecução das obrigações e suas consequências. 5. ed. São Paulo: Saraiva, 1980. p. 117.
} 
Nesse sentido o art. 397 do Código Civil ${ }^{271}$, que define que o inadimplemento de obrigação que seja positiva e líquida enseja automaticamente a mora do devedor, sem necessidade de interpelação, significando que, havendo termo definido para cumprimento de obrigação, estar-se-á diante da mora, se o devedor deixar de prestar no prazo definido.

Na hipótese de não haver prazo estipulado, o credor, previamente à caracterização da mora, deve manifestar-se para estipular prazo para que o devedor cumpra sua obrigação, sendo que apenas após o término do prazo indicado pelo credor, e em caso de não cumprimento, estará caracterizada a mora.

Entretanto, se a obrigação for estipulada a termo essencial, a impossibilidade temporária equipara-se à definitiva pela estipulação das partes de que, se a obrigação não for cumprida no prazo acordado, haverá automático desinteresse na prestação por parte do credor, o que ocorre, por exemplo, na aquisição de vestido de noiva, que serve especificamente para a ocasião do casamento ${ }^{272}$.

O termo essencial faz com que, vencida a obrigação, a coisa se torne inútil automaticamente, por perder sua identidade ${ }^{273}$.

Segundo Jorge Cesa Ferreira da Silva, a mora, ainda que o art. 394 do Código Civil mencione lugar e forma, está sempre relacionada a tempo, "consubstanciando um atraso relativo à prestação devida", já que haverá necessariamente prazo para correção da prestação, ou seja, a purgação da mora ${ }^{274}$.

Razão não cabe à limitação do conceito da mora às hipóteses em que há atraso na prestação, ainda que se possa concordar com o entendimento de que a mora acaba por se relacionar ao tempo, no sentido do prazo necessário para correção da prestação.

Seguindo a lógica do Direito das Obrigações, em caso de mora, permite-se sua purgação pelo devedor, desde que não haja conversão da mora em inadimplemento absoluto.

\footnotetext{
271، Art. 397. O inadimplemento da obrigação, positiva e líquida, no seu termo, constitui de pleno direito em mora o devedor. Parágrafo único. Não havendo termo, a mora se constitui mediante interpelação judicial ou extrajudicial.".

${ }^{272}$ Conforme AGUIAR JÚNIOR, Ruy Rosado de. Extinção dos contratos por incumprimento do devedor: Resolução - de acordo com o novo Código Civil, cit., p. 118.

${ }^{273}$ TERRA, Aline de Miranda Valverde. Inadimplemento anterior ao termo, cit., p. 74.

${ }^{274}$ SILVA, Jorge Cesa Ferreira da. A boa-fé e a violação positiva do contrato. Rio de Janeiro: Renovar, 2002. p. 148.
} 
Para Pontes de Miranda, só se fala de mora, se o adimplemento ainda pode ser feito, mas, se em razão do atraso, a prestação não mais interessar ao credor, a mora deixa de ser purgável, tornando o inadimplemento inafastável ${ }^{275}$.

Assim, enquanto houver a possibilidade, objetiva, de se cumprir a obrigação, estar-se-á diante de mora, purgável.

A distinção entre mora e inadimplemento resvala, comumente, na possibilidade ou não de se cumprir a obrigação ou na existência ou não de interesse útil do credor em relação à prestação, como se verá no item a seguir.

\subsubsection{Inadimplemento}

Ruy Rosado explana que o incumprimento pode ser classificado, quanto aos efeitos, em incumprimento definitivo, se a prestação não puder mais ser efetuada (impossibilidade) ou exigida (modificação superveniente das circunstâncias), ou, sendo possível e exigível, não tiver mais utilidade para o credor; em incumprimento nãodefinitivo $^{276}$, quando persiste a possibilidade, a exigibilidade e o interesse do credor, mas a prestação não é efetuada no tempo, modo e lugar convencionados (mora); e em cumprimento defeituoso, quando é realizada a prestação, mas de modo imperfeito ${ }^{277}$.

Pedro Romano Martinez cita que o Código Civil português prevê três causas que podem dar origem ao não cumprimento definitivo: impossibilidade, perda do interesse por parte do credor e o decurso de um prazo suplementar para cumprimento estabelecido pelo credor, tendo a doutrina acrescentado a quarta causa, relacionada à declaração expressa do devedor de que não irá cumprir sua obrigação ${ }^{278}$.

\footnotetext{
${ }^{275}$ PONTES DE MIRANDA, Francisco Cavalcanti. Tratado de direito privado, cit., t. 26, p. 35. Agostinho Alvim trata da mesma forma, em Da inexecução das obrigações e suas consequências, cit., p. 157.

${ }^{276}$ Veja-se que Araken de Assis define o incumprimento definitivo como inadimplemento absoluto, que ocorre quando "patenteada a irreversibilidade do descumprimento", ou seja, quando a obrigação não puder ser cumprida, e o incumprimento não-definitivo como inadimplemento relativo. ASSIS, Araken de. Resolução do contrato por inadimplemento, cit., p. 100-102.

${ }^{277}$ AGUIAR JÚNIOR, Ruy Rosado de. Extinção dos contratos por incumprimento do devedor: Resolução de acordo com o novo Código Civil, cit., p. 94.

${ }^{278}$ MARTINEZ, Pedro Romano. Cumprimento defeituoso: em especial na compra e venda e na empreitada. Coimbra: Almedina, 2001. p. 122.
} 
Em relação à impossibilidade, entende-se que aquela que surge no momento da formação do negócio jurídico enseja sua nulidade ${ }^{279}$, sendo a superveniente ensejadora do inadimplemento $^{280}$.

Deve-se ressaltar entendimento de que a extrema dificuldade de prestar, para o devedor, equipara-se a impossibilidade ${ }^{281}$.

Importante distinção refere-se à impossibilidade relativa e a absoluta, sendo aquela intimamente ligada à pessoa do devedor e esta caracterizada pela impossibilidade que qualquer terceiro enfrentaria, como no caso de perecimento do objeto da prestação ${ }^{282}$.

Sendo caso de impossibilidade relativa, a insolvência, via de regra, é também definida pela ausência de culpa do devedor, não ensejando, assim, mora pelo Direito Brasileiro, que demanda a culpa. No entanto, o Código Civil traz algumas consequências em caso de insolvência do devedor, geralmente definindo o vencimento antecipado de dívida ${ }^{283}$.

Não obstante, a própria lei atinente a incorporação imobiliária prevê medidas de forma a evitar as consequências prejudiciais aos adquirentes em casos de insolvência do incorporador, como se verá no capítulo 5.

O objeto da prestação é comumente visto com base na realização do interesse do credor e da utilidade da prestação para este, como disposto no parágrafo único do art. 395

\footnotetext{
${ }^{279}$ Conforme demonstram os arts. 166 e 167 do Código Civil: “Art. 166. É nulo o negócio jurídico quando: I celebrado por pessoa absolutamente incapaz; II - for ilícito, impossível ou indeterminável o seu objeto; III o motivo determinante, comum a ambas as partes, for ilícito; IV - não revestir a forma prescrita em lei; V for preterida alguma solenidade que a lei considere essencial para a sua validade; VI - tiver por objetivo fraudar lei imperativa; VII - a lei taxativamente o declarar nulo, ou proibir-lhe a prática, sem cominar sanção." e "Art. 167. É nulo o negócio jurídico simulado, mas subsistirá o que se dissimulou, se válido for na substância e na forma. § $1^{\circ}$ Haverá simulação nos negócios jurídicos quando: I - aparentarem conferir ou transmitir direitos a pessoas diversas daquelas às quais realmente se conferem, ou transmitem; II contiverem declaração, confissão, condição ou cláusula não verdadeira; III - os instrumentos particulares forem antedatados, ou pós-datados.

${ }^{280}$ SILVA, Jorge Cesa Ferreira da. A boa-fé e a violação positiva do contrato, cit., p. 132.

${ }^{281}$ Conforme, exemplificativamente, SILVA, Jorge Cesa Ferreira da. A boa-fé e a violação positiva do contrato, cit., p. 133, e GUIMARÃES, Paulo Jorge Scartezzini. Vícios do produto e do serviço por qualidade, quantidade e insegurança: cumprimento imperfeito do contrato, cit., p. 88.

${ }^{282}$ Conforme SILVA, Jorge Cesa Ferreira da. A boa-fé e a violação positiva do contrato, cit., p. 134.

${ }^{283} \mathrm{O}$ art. 333 do Código Civil, por exemplo, permite ao credor a cobrança de dívida antes do prazo, em casos que indicam a incapacidade econômica do devedor, como no caso de falência ou concurso de credores, penhora de bens em execução movida por outros credores e de negação de reforços de garantias dadas pelo devedor, se estas cessarem ou forem insuficientes. O art. 1.425, II, do mesmo Código, prevê o vencimento antecipado da dívida relativa a contratos de penhor, hipoteca ou anticrese, na hipótese de o devedor cair em insolvência ou falir.
} 
do Código Civil ${ }^{284}$, o que influi na verificação das situações relacionadas ao descumprimento de obrigações.

Muito se discute acerca do interesse e da utilidade acima mencionadas, sendo que Ruy Rosado afirma que, para se aferir a inutilidade, deve-se partir do interesse do credor $^{285}$.

O interesse do credor assume relevância, podendo haver a possibilidade de prestar, sem que haja, contudo, manutenção do interesse do credor em tal prestação.

Não obstante, Aline Terra cita que a relação obrigacional impõe seu reconhecimento como mecanismo de satisfação do interesse das partes, apesar de haver, de fato, um interesse premente, que justifica a imposição de limitação à liberdade do devedor $^{286}$. Lucas Gaspar de Oliveira Martins também entende que os interesses do devedor não podem ser desprezados, devendo tais interesses ser incluídos no conceito de adimplemento ${ }^{287}$.

Nessa toada, o Enunciando 162, aprovado na III Jornada de Direito Civil organizada pelo Conselho da Justiça Federal, que define que a inutilidade da prestação deve ser aferida objetivamente e não de acordo com o mero interesse subjetivo do credor ${ }^{288}$.

Caberá ao juiz, tendo em vista cada caso, a decisão quanto à inutilidade da prestação ou à diminuição da utilidade, devendo-se afastar qualquer pretensão que não seja razoável, inclusive o simples arrependimento do credor em relação à prestação ${ }^{289}$, de forma que não se permita que o credor determine de forma tão intensa a relação obrigacional.

\footnotetext{
${ }^{284}$ Parágrafo único. Se a prestação, devido à mora, se tornar inútil ao credor, este poderá enjeitá-la, e exigir a satisfação das perdas e danos.

${ }^{285}$ AGUIAR JÚNIOR, Ruy Rosado de. Extinção dos contratos por incumprimento do devedor: Resolução de acordo com o novo Código Civil, cit., p. 131-132.

${ }^{286}$ TERRA, Aline de Miranda Valverde. Inadimplemento anterior ao termo, cit., p. 23.

${ }^{287}$ MARTINS, Lucas Gaspar de Oliveira. Mora: inadimplemento absoluto e adimplemento substancial das obrigações. São Paulo: Saraiva, 2011. p. 23.

288،A inutilidade da prestação que autoriza a recusa da prestação por parte do credor deverá ser aferida objetivamente, consoante o princípio da boa-fé e a manutenção do sinalagma, e não de acordo com o mero interesse subjetivo do credor."

${ }^{289}$ Nesse sentido, Agostinho Alvim, para quem, dominando a casuística em caso de mora, somente ao juiz, tendo em vista cada caso, se permite decidir se a falta arguida pelo credor é tal que a prestação se lhe tornou inútil, ou somente menos valiosa, não permitindo a lei que o credor, arrependido do negócio, queira se prevalecer de uma imperfeição relevável para rejeitar a prestação. ALVIM, Agostinho. Da inexecução das obrigações e suas consequências, cit., p. 52.
} 
Veja-se, ainda, a questão da recusa de prestar, pelo devedor, sendo uma das hipóteses ventiladas quanto à impossibilidade da prestação ${ }^{290}$, especialmente se se tratar de obrigação personalíssima, pois, neste caso, não se pode substituir a prestação, e, dessa forma, o credor não pode obter a prestação por intermédio de terceiros ${ }^{291}$.

A indicação de que o devedor não cumprirá a obrigação pode ser tácita ou expressa.

Segundo Azulay $^{292}$, a declaração do devedor de que não quer ou não pode adimplir é declaração unilateral de vontade, devendo, dessa forma, ser recebida pelo credor, para que passe a ter efeitos.

Assim, se o credor jamais recebeu a declaração, esta não produziu efeitos, não sendo necessário se falar em retratação. Tendo recebido a declaração, contudo, cabe reiterar o conceito do venire contra factum proprium, ligado à boa-fé, que significa, segundo Luciano Camargo Penteado, "vir contra um fato próprio", que não autoriza uma pessoa a contrariar um comportamento por si mesmo praticado anteriormente ${ }^{293}$.

A manifestação tácita advém de atos ou fatos que demonstrem a recusa do devedor ao cumprimento de sua obrigação.

Araken de Assis ressalta o entendimento, identificando a omissão da atividade causal concernente ao futuro como comportamento inerente ao inadimplemento antecipado $^{294}$, e assim indica: "É imaginável, outrossim, nada ter o devedor aparelhado

\footnotetext{
${ }^{290}$ Ruy Rosado entende possível "se o devedor pratica atos nitidamente contrários ao cumprimento ou faz declarações expressas nesse sentido, acompanhadas de comportamento efetivo contra a prestação, de tal sorte que se possa deduzir conclusivamente, dos dados objetivos existentes, que não haverá o cumprimento", incluindo-se, dessa forma, a declaração expressa ou a apresentação de conduta contrária ao cumprimento, por ação ou omissão, o que inclui deixar de tomar as providências necessárias para que seja possível a prestação, excluindo-se a simples dificuldade ou a impossibilidade temporária. AGUIAR JÚNIOR, Ruy Rosado de. Extinção dos contratos por incumprimento do devedor: Resolução - de acordo com o novo Código Civil, cit., p. 126 e ss.

${ }^{291}$ Conforme Agostinho Alvim, a recusa equivalerá a inadimplemento absoluto se se tratar de fato pessoal e uma obrigação infungível. ALVIM, Agostinho. Da inexecução das obrigações e suas consequências, cit., p. 43.

${ }^{292}$ AZULAY, Fortunato. Do inadimplemento antecipado do contrato. Rio de Janeiro: Ed. Brasília, Ed. Rio, 1977. p. 79.

${ }^{293}$ PENTEADO, Luciano de Camargo. Figuras parcelares da boa-fé objetiva $e$ venire contra factum proprium. Disponível em: <http://www.flaviotartuce.adv.br/secoes/artigosc/Luciano_venire.doc>. Acesso em: 17 jun. 2010.

${ }^{294}$ Teoria baseada na doutrina do anticipatory breach do contrato, surgida na Inglaterra nos meados do século retrasado, e consagrada nos Estados Unidos da América, determinando-se pela revelação de um dos contraentes, "por atos ou palavras peremptórias e inequívocas", da intenção de não cumprir sua prestação, podendo a outra parte considerar tal comportamento como inadimplemento. (AZULAY, Fortunato. Do inadimplemento antecipado do contrato, cit., p. 101).A aplicação da teoria do inadimplemento antecipado no Direito brasileiro é discutida uma vez que não há, em nosso ordenamento, sua tipificação, sendo que as
} 
com destino ao cumprimento, tornando fatal o inadimplemento(...)"295.

Nesse sentido, é comum identificar a omissão em relação aos atos necessários para que haja cumprimento de uma obrigação, que se verifica de forma mais evidente em casos de obrigação complexa, cujo cumprimento depende de diversos atos, como é o caso da incorporação imobiliária.

A modificação superveniente das circunstâncias, que não seja meramente pessoal ou esteja na área de influência da parte prejudicada ${ }^{296}$, refere-se à alteração da base objetiva do negócio, sendo esta "o conjunto de circunstâncias e o estado geral das coisas, cuja existência ou subsistência é objetivamente necessária para que o contrato, segundo o significado das intenções de ambos os contratantes, possa subsistir como regulação dotada de sentido",297.

Verifica-se que o Código Civil atual não define o inadimplemento absoluto, limitando-se, ao tratar do inadimplemento das obrigações, no TÍTULO IV do Livro "DO

normas civis de nosso País não indicam expressamente a possibilidade de admissão da mora ou do inadimplemento previamente ao termo da obrigação. Contudo, teve, na doutrina, grande aceitação, e vem sendo aplicada pelos julgadores pátrios, conforme julgados relacionados à aplicação da teoria do inadimplemento antecipado localizados, como REsp 309626/RJ, 4 ${ }^{\mathrm{a}}$ Turma, STJ, Rel. Min. Ruy Rosado de Aguiar, julgamento em 07.06.01, Apelação nº 0117017-71.2008.8.19.0002, $18^{\mathrm{a}}$ Câmara Cível, TJ/RJ, Rel. Des. Célia Maria Vidal Meliga Pessoa, julgamento em 07.01.2011; AI nº 0004042-10.2011.8.19.0000, 20ª Câmara Cível, TJ/RJ, Rel. Des. Odete Knaack de Souza, julgamento em 27.04.2011; Apelação nº 000151885.2002.807.00001, $1^{\mathrm{a}}$ Turma Cível, TJ/DF, Rel. Des. Hermenegildo Gonçalves, julgamento em 13.05.2002; Apelação no 0110649-33.2003.8.26.0000, 9a Câmara de Direito Privado, TJ/SP, Rel. Des. Piva Rodrigues, julgamento em 09.03.2010.

${ }^{295}$ ASSIS, Araken de. Resolução do contrato por inadimplemento, cit., p. 89.

${ }^{296}$ AGUIAR JÚNIOR, Ruy Rosado de. Extinção dos contratos por incumprimento do devedor: Resolução de acordo com o novo Código Civil, cit., p. 146.

${ }^{297}$ Larenz, Karl. Base del negocio jurídico y cumplimiento de los contratos. Revista de Derecho Privado, Editorial, Madri, 1956, p. 224 apud AGUIAR JÚNIOR, Ruy Rosado de. Extinção dos contratos por incumprimento do devedor: Resolução - de acordo com o novo Código Civil, cit., p. 145. Cabe esclarecer que o assunto tem conexão com a teoria da imprevisão e onerosidade excessiva, sendo que os arts. 478 a 480 do Código Civil preveem a resolução do contrato por onerosidade excessiva, aplicável aos contratos de execução continuada ou diferida, podendo have manutenção do contrato se o réu modificar as condições contratuais: "Art. 478. Nos contratos de execução continuada ou diferida, se a prestação de uma das partes se tornar excessivamente onerosa, com extrema vantagem para a outra, em virtude de acontecimentos extraordinários e imprevisíveis, poderá o devedor pedir a resolução do contrato. Os efeitos da sentença que a decretar retroagirão à data da citação."; “Art. 479. A resolução poderá ser evitada, oferecendo-se o réu a modificar eqüitativamente as condições do contrato." e "Art. 480. Se no contrato as obrigações couberem a apenas uma das partes, poderá ela pleitear que a sua prestação seja reduzida, ou alterado o modo de executá-la, a fim de evitar a onerosidade excessiva. No Código de Defesa do Consumidor, essa questão é tratada de forma mais ampla, por exemplo, permitindo que o consumidor pleite a revisão mesmo que seja previsível, bastando a desproporcionalidade de prestações em razão de fatos supervenientes que as tornem excessivamente onerosas, nos termos do art. $6^{\circ}, \mathrm{V}$ : "a modificação das cláusulas contratuais que estabeleçam prestações desproporcionais ou sua revisão em razão de fatos supervenientes que as tornem excessivamente onerosas". 
DIREITO DAS OBRIGAÇÕES”, a definir a consequência do descumprimento, conforme art. $389^{298}$.

\subsubsection{Cumprimento defeituoso}

Muitos autores definem o cumprimento imperfeito ou defeituoso ${ }^{299}$, havendo caracterização de tal cumprimento, ou descumprimento, como terceira modalidade de inadimplemento, muitas vezes denominada de violação positiva do contrato ${ }^{300}$.

Segundo Ruy Rosado, tal descumprimento caracteriza-se nos casos em que há execução defeituosa da prestação quanto ao modo, pressupondo, assim, a existência da prestação, mas efetivada de modo contrário à lei ou ao acordado entre as partes ${ }^{301}$.

De acordo com Paulo Scartezzini Guimarães, “(...) se refere a toda prestação realizada pelo devedor em que seu comportamento está em desacordo com o que foi previamente estipulado", sendo mora e podendo incluir os vícios de qualidade e quantidade $^{302}$.

Jorge Cesa também entende aceitável essa conclusão, ainda que para tanto seja necessária a adoção do conceito da violação positiva do contrato ${ }^{303}$, que seria diverso do conceito de cumprimento defeituoso, abrangendo, contudo, hipóteses deste.

Pedro Romano Martinez igualmente entende que o cumprimento defeituoso pode abarcar hipóteses de prestação em tempo e local inadequados, em quantidade ou qualidade

\footnotetext{
${ }^{298}$ Art. 389. Não cumprida a obrigação, responde o devedor por perdas e danos, mais juros e atualização monetária segundo índices oficiais regularmente estabelecidos, e honorários de advogado.

${ }^{299}$ Nesse sentido, AGUIAR JÚNIOR, Ruy Rosado de. Extinção dos contratos por incumprimento do devedor: Resolução - de acordo com o novo Código Civil, cit.; GUIMARÃES, Paulo Jorge Scartezzini. Vícios do produto e do serviço por qualidade, quantidade e insegurança: cumprimento imperfeito do contrato, cit.; e Pedro Romano Martinez, em Cumprimento defeituoso: em especial na compra e venda e na empreitada, cit.

${ }^{300}$ Jorge Cesa define a violação positiva do contrato no Brasil como "o inadimplemento decorrente do descumprimento culposo do dever lateral, quando este dever não tenha uma vinculação direta com os interesses do credor na prestação". SILVA, Jorge Cesa Ferreira da. A boa-fé e a violação positiva do contrato, cit., p. 266.

${ }^{301}$ AGUIAR JÚNIOR, Ruy Rosado de. Extinção dos contratos por incumprimento do devedor: Resolução de acordo com o novo Código Civil, cit., p. 119 e ss.

${ }^{302}$ Conforme Paulo Jorge Scartezzini Guimarães, é desnecessária a criação de terceira espécie de inadimplemento, sendo que os vícios de qualidade e quantidades guardam certa autonomia legislativa. Em Vícios do produto e do serviço por qualidade, quantidade e insegurança: cumprimento imperfeito do contrato, cit., p. 106 e 136.

${ }^{303}$ SILVA, Jorge Cesa Ferreira da. A boa-fé e a violação positiva do contrato, cit., p. 204-205.
} 
diversa, inclusive se entregue coisa diversa, defendendo, pois, a noção de que o cumprimento defeituoso abarca os vícios da coisa ${ }^{304}$.

Deve-se ressaltar que o art. 394 do Código Civil brasileiro não prevê expressamente o modo de prestação para qualificar a mora, além de não haver, igualmente, definição nesse sentido no que se refere ao inadimplemento, o que poderia justificar a necessidade da aclamação da terceira forma de descumprimento.

Contudo, com base na doutrina de Paulo Jorge Scartezzini Guimarães, acima citada, e de Pontes de Miranda, que entendia que o conceito da mora abrangia irregularidade quanto ao modo de prestar ${ }^{305}$, o cumprimento defeituoso pode ser mora, se sanável, ou descumprimento definitivo, se há perda de interesse do credor na prestação, ainda que tenha havido prestação.

Para fins de facilitação da estruturação do presente trabalho, interpretar-se-á que os vícios redibitórios, ainda que possam ser garantia ao adquirente e ter natureza controvertida, são hipótese de cumprimento defeituoso por não haver entrega da coisa

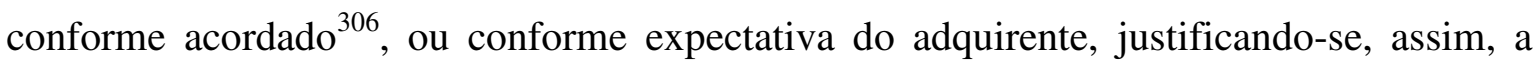
inclusão de tal assunto como subitem abaixo.

\subsubsection{Vícios redibitórios}

Kunkel $^{307}$ explana que o caso mais antigo de responsabilidade por vícios da coisa é encontrado na compra e venda mancipatória, sendo que, à falta de correspondência entre a área declarada pelo vendedor na mancipatio e sua verdadeira extensão, o vendedor respondia pela actio de modo agri.

\footnotetext{
${ }^{304}$ MARTINEZ, Pedro Romano. Cumprimento defeituoso: em especial na compra e venda e na empreitada, cit., p. 130 e ss.

${ }^{305}$ PONTES DE MIRANDA, Francisco Cavalcanti. Tratado de direito privado, cit., v. 26, p. 33 e ss.

${ }^{306}$ Veja-se que Pontes de Miranda define o adimplemento ruim como a prestação com defeitos ou vícios do objeto, sendo, pois, inadimplemento. PONTES DE MIRANDA, Francisco Cavalcanti. Tratado de direito privado: parte especial. Rio de Janeiro: Ed. Borsoi, 1962. t. 38, p. 148.

${ }^{307}$ Jöers-Kunkel, Römisches Recht, $2^{\text {a }}$ ed., parágrafo 144, p. 234 Apud MOREIRA ALVES, José Carlos. Direito romano. 5. ed. Rio de Janeiro: Forense, 1995. v. 2, p. 194. Entendimento esposado igualmente por PONTES DE MIRANDA, Francisco Cavalcanti. Tratado de direito privado: parte especial, cit., t. 38, p. 276.
} 
Segundo Moreira Alves ${ }^{308}$, no tempo de Cícero, passou-se a aceitar que o comprador ingressasse com actio empti para obter devolução de preço mediante restituição da coisa ou abatimento. Posteriormente, os edis curuis (ou aediles curules), que regulavam o mercado, instituíram, em benefício dos compradores de animais ou escravos, a obrigação de o vendedor tornar públicos os vícios das coisas, e, em caso de escravos, de celebrar a stipulatio duplae, sendo que, posteriormente, referidos edis previram a actio redhibitoria, para devolução do preço mediante restituição da coisa, e a actio quanti minoris, para redução do preço.

Thomas Marky $^{309}$, em relação às ações admitidas pelos edis, denominadas comumente de ações edilícias, menciona que, no início, não eram admitidas para vendas sem estipulações, sendo que mais tarde ambas passaram a valer para todos os negócios de compra e venda.

Com a formação dos contratos consensuais e o aperfeiçoamento das exigências relativas, de bona fides, passou-se a admitir, já no século II a.C., a actio ex empto, que era cabível ainda se a venda fosse realizada sem formalidades, mas dependia da prova de dolo do vendedor ${ }^{310}$.

No tempo de Justiniano, entende-se que a actio empti servia para a função da ação redibitória e da ação quanti minoris, tendo sido mantida ${ }^{311}$.

Sabe-se que após o período romano, o campo jurídico, entre outros, tornou-se vazio, ensejando um "primitivismo jurídico", tendo pouco sido discutido ou inovado, no que se refere aos vícios redibitórios, até o século XVI, quando teria surgido o caveat emptor, que, segundo Scartezzini, determinava a assunção da responsabilidade pelo comprador, impondo maior acautelamento por este quanto ao bem adquirido ${ }^{312}$.

Tal ideal, contudo, perdeu força, até a promulgação dos códigos, a partir do século XIX, que, genericamente, se basearam nos preceitos romanos relativos aos vícios redibitórios e às ações edilícias.

\footnotetext{
${ }^{308}$ MOREIRA ALVES, José Carlos. Direito romano, cit., v. 2, p. 194.

${ }^{309}$ MARKY, Thomas. Curso elementar de direito romano. 8. ed. São Paulo: Saraiva, 1995. p. 80.

${ }^{310}$ POVEDA VELASCO, Ignacio M. Proteção do comprador no direito romano. São Paulo: Cultural Paulista, 2002. p. 59.

${ }^{311}$ MOREIRA ALVES, José Carlos. Direito romano, cit., v. 2, p. 195.

${ }^{312}$ Conforme GUIMARÃES, Paulo Jorge Scartezzini. Vícios do produto e do serviço por qualidade, quantidade e insegurança: cumprimento imperfeito do contrato, cit., p. 39 e 46.
} 
A doutrina diverge acerca da natureza jurídica dos vícios redibitórios, havendo teorias que se baseiam no inadimplemento; outras que se baseiam no estado psicológico do adquirente; outras que se baseiam simplesmente no princípio da equidade ${ }^{313}$.

Outros entendem se tratar de princípio de garantia, inerente ao contrato comutativo $^{314}$.

Segundo Jorge Cesa Ferreira, os vícios caracterizam-se por desconformidades no objeto da prestação, na própria coisa, sendo hipótese diversa da teoria do erro, posto que esta baseia-se na falsa percepção quanto ao objeto existente no momento da celebração do negócio, ou seja, vício na vontade, enquanto os vícios redibitórios baseiam-se na existência de um defeito na coisa, que venha a se mostrar posteriormente à entrega da coisa, independentemente de percepção ou entendimento subjetivo ${ }^{315}$.

Ressalte-se, que não se trata de hipótese de coisa diversa, que poderia gerar inadimplemento contratual $^{316}$, tendo em vista que os vícios redibitórios referem-se a defeitos existentes na coisa efetivamente contratada.

As regras atinentes aos vícios redibitórios têm, de fato, função de garantia específica em relação à entrega de coisa que, mesmo que não diversa do acordado, seja completamente viciada. Entretanto, também se referem a uma responsabilidade inerente à contratação, de forma a se homenagear a equivalência das prestações, justamente pela comutavidade do contrato, não se podendo presumir que a intenção do comprador-credor seja de receber coisa defeituosa, ainda que tenha pago por coisa perfeita.

\footnotetext{
${ }^{313}$ Como explicita MONTEIRO DE BARROS, Washington. Curso de direito civil: direito das obrigações. 34. ed. São Paulo: Saraiva, 2003. v. 5, 2 pt., p. 47 e ss. Referido doutrinador defende a tese do inadimplemento, que gera responsabilidade contratual, por haver defeito que torne a coisa inapta aos seus fins ou lhe diminua o valor.

${ }^{314}$ Entendimento esposado por Caio Mario da Silva Pereira, Instituições de direito civil: contratos. 16. ed. Rio de Janeiro: Forense, 2012. v. 3, p. 105 e ss, e por GOMES, Orlando. Contratos, cit., 24. ed., p. 93. Ainda, julgamento do REsp 873165 / ES, STJ, Rel. Min. Sidnei Beneti, Terceira Turma, julg. Em 18/05/2010, que define que tanto a evicção quanto os vícios redibitórios ssentam-se na teoria da garantia: "DIREITO CIVIL. GARANTIA CONTRA EVICÇÃO. NATUREZA JURÍDICA. REQUISITOS. I - Evicção é a perda da coisa, determinada em regra por sentença judicial, que a atribui a outrem, por direito anterior ao contrato aquisitivo. Gera, contra o alienante, responsabilidade civil que se funda no mesmo princípio de garantia que o vincula em face dos vícios redibitórios. (...)".

${ }^{315}$ Vide doutrina de Jorge Cesa, A Boa-Fé..., p. 167, 183 e ss. Scartezzini também a afasta, por haver vício na vontade e não na coisa, sendo que o vício na coisa deve ocorrer no momento da tradição e o da vontade no momento da formação do negócio. GUIMARÃES, Paulo Jorge Scartezzini. Vícios do produto e do serviço por qualidade, quantidade e insegurança: cumprimento imperfeito do contrato, cit., p. 123 e ss.

${ }^{316}$ Veja-se que, na Apelação Cível $n^{\circ} 775.443-0$, da $4^{\text {a }}$ Câmara (Extinto $1^{\circ}$ TAC), do TJ/SP, julgada em 04/08/1999, tendo como Rel. Des. Oseas Davi Viana, referido órgão julgador alterou sentença de primeiro grau que previa que a entrega de coisa sem a qualidade esperada era inadimplemento, tendo a Corte defendido, com razão, que se tratava da entrega de coisa contratada, mas com vícios (falta de qualidade), admitindo a redução do preço com base no art. 18, parágrafo $3^{\circ}$ do Código de Defesa do Consumidor, ainda que tenha correspondência na regulação do Código Civil quanto aos vícios redibitórios.
} 
Verificados alguns conceitos e o breve histórico relacionado aos vícios redibitórios, avaliar-se-á o regramento legal correspondente.

\subsection{Regulação pelo Código Civil}

$\mathrm{Na}$ concepção tradicional, vinculada à regulação das relações civis, há de se ressaltar o disposto no art. 441 do Código Civil, que define que, em contrato comutativo, a coisa recebida pode ser enjeitada se houver vícios ou defeitos ocultos que tornem aludida coisa imprópria ao seu uso ou lhe diminuam o valor ${ }^{317}$.

Pela literalidade do artigo, a proteção está incorporada nos contratos comutativos, em que há equivalência das prestações, devendo haver gravidade no defeito, de forma que sua utilidade ou o seu valor seja afetado.

Ademais, o vício amparado é o vício oculto, não perceptível ao homem comum, no momento do recebimento da coisa, respondendo o alienante mesmo se o vício já existente antes da entrega da coisa vier a ocasionar seu perecimento quando já em poder do adquirente $^{318}$.

O art. 443 do Código Civil ${ }^{319}$ distingue hipóteses em que o alienante conhecia ou não o vício, de forma a determinar a reparação por perdas e danos causados ao adquirente, sendo que a ignorância dos vícios pelo alienante não o exime da responsabilidade pela restituição de valor, mas sim em relação a perdas e danos.

Isto quer dizer que, tendo agido de boa-fé, somente restituirá o valor recebido, mais as despesas do contrato. De forma contrária, sabendo do vício e tendo, pois, agido de má-fé, além de restituir o que recebeu, responderá também por perdas e danos ${ }^{320}$.

\footnotetext{
317“Art. 441. A coisa recebida em virtude de contrato comutativo pode ser enjeitada por vícios ou defeitos ocultos, que a tornem imprópria ao uso a que é destinada, ou lhe diminuam o valor".

${ }^{318}$ Tal é a previsão do art. 444: “Art. 444. A responsabilidade do alienante subsiste ainda que a coisa pereça em poder do alienatário, se perecer por vício oculto, já existente ao tempo da tradição.”.

319"Art. 443. Se o alienante conhecia o vício ou defeito da coisa, restituirá o que recebeu com perdas e danos; se o não conhecia, tão-somente restituirá o valor recebido, mais as despesas do contrato".

${ }^{320}$ Quanto ao ressarcimento de danos, o legislador brasileiro seguiu o italiano, havendo, no art. 1.494 do Código Civil italiano, a previsão de que o alienante responderá também por perdas e danos, exceto se provar que não conhecia o vício: "In ogni caso il venditore è tenuto verso il compratore al risarcimento del danno (1223), se non prova di avere ignorato senza colpa i vizi della cosa.

Il venditore deve altresì risarcire al compratore i danni derivati dai vizi della cosa."
} 
Veja-se entendimento apropriado de que se o adquirente conhecia o vício, responsabilidade do vendedor não há, pois conscientemente aquele celebrou contrato prevendo a remuneração para a coisa viciada ${ }^{321}$.

A existência de vício redibitório na coisa enseja a escolha, pelo credor $^{322}$, entre o direito de rejeitar a coisa, determinando a redibição do contrato ${ }^{323}$, e o de permanecer com a coisa, mantendo o contrato, requerendo, contudo, o ajuste no preço, por meio da actio quanti minoris.

Na hipótese de redibição, o adquirente deve devolver a coisa de forma a ter o preço pago por ela restituído, objetivando que as partes retornem ao status quo ante. Nesse sentido, devolvendo-se a coisa ao alienante, a ele devem ser devolvidos também os acessórios e frutos da coisa, de forma a se manter o equilíbrio contratual e a se evitar qualquer enriquecimento sem causa, assim como é razoável a determinação de pagamento de valores pelo uso do bem, o que é comum em casos de imóveis, determinando-se, neste caso, o pagamento de valor de locação da coisa nesse período.

A devolução do valor efetivamente pago pelo adquirente deve seguir a regra contida no art. 395 do Código Civil ${ }^{324}$, abrangendo, assim, correção do valor pago, juros de mora e honorários advocatícios.

Hipóteses mencionadas por Scartezzini são ligadas à impossibilidade de devolução da coisa pelo comprador: se por nova alienação a terceiro, entende só poder haver ação redibitória se o antigo adquirente retomar o bem. Se for impossível devolver a coisa por ter esta perecido, o Código Civil traz regras expressas quanto às consequências, definindo seu art. 444 que se a coisa perecer após a tradição em razão do vício oculto,

\footnotetext{
${ }^{321}$ Como MONTEIRO DE BARROS, Washington. Curso de direito civil: direito das obrigações: $1^{\text {a }}$ parte: das modalidades, das obrigações, dos efeitos das obrigações, do inadimplemento das obrigações. 32. ed. São Paulo: Saraiva, 2003. p. 64, e PONTES DE MIRANDA, Francisco Cavalcanti. Tratado de direito privado: parte especial, cit., t. 38, p. 285.

${ }^{322}$ Veja-se entendimento do STJ, no julgamento do REsp 950522 / PR, Ministro Luis Felipe Salomão, Quarta Turma, julg. em 18/08/2009, definindo que não pode o devedor exercer a escolha: “(...)1.6. O arcabouço normativo aplicável à espécie é o relativo a vícios redibitórios. Nesse passo, diante do tempo decorrido desde a propositura da ação, assim também a recusa sistemática do réu em realizar as obras de reparo, nem o Código Civil de 1916 (art. 1.101 a art. 1.106), nem o Código Civil de 2002 (art. 441 a art. 446), tampouco o Código de Defesa do Consumidor (art. 18 a art. 25), conferem ao devedor o direito de escolher sanar os vícios na construção do imóvel ou pagar indenização por perdas e danos, e, inexistindo a possibilidade de se analisar o contrato, para se verificar se neste contém tal previsão (Súmula 05), resta rejeitada a pretensão do recorrente de, a essa altura, realizar as obras.(...)".

${ }^{323}$ Conforme parte inicial do art. 442 do Código Civil: “Art. 442. Em vez de rejeitar a coisa, redibindo o contrato (art. 441), pode o adquirente reclamar abatimento no preço."

324، Art. 395. Responde o devedor pelos prejuízos a que sua mora der causa, mais juros, atualização dos valores monetários segundo índices oficiais regularmente estabelecidos, e honorários de advogado."
} 
responde o vendedor. Em outro caso, responde o comprador, que, sem poder devolver a coisa, não terá direito à ação redibitória, tão somente a de abatimento de preço ou indenizatória, se o caso ${ }^{325}$.

Referidos argumentos mostram-se plausíveis, em razão da regra res perit domino, de forma que, se a coisa foi transferida ao adquirente, este assume o risco.

Caso seja de interesse do credor, pode-se manter o contrato e a coisa em seu poder, mediante, contudo, abatimento de preço $^{326}$, tendo em vista que se deve manter a correlação entre prestação e contraprestação, em razão do sinalagma.

Não obstante carecer o Código Civil de definição nesse sentido, Paulo Scartezinni defende uma terceira opção ao comprador, qual seja a de requerer a substituição da coisa adquirida ou a reparação do vício, pois ainda que o vendedor não seja fabricante e não tenha outro produto para substituir ou não tenha meios técnicos para reparar um vício, pode obter a solução do vício por terceiros.

O STJ, em antigo caso referente a vícios redibitórios, afirmou a existência apenas das duas possibilidades previstas no Código Civil, fazendo menção à substituição de uma coisa que fora comprada em conjunto com outras, apenas por ter o vendedor oferecido a substituição do bem, ainda que sem referência alguma ao Código de Defesa do Consumidor, que já estava vigendo na data do julgamento ${ }^{327}$.

Razão assiste à definição de cabimento das opções expressamente previstas no Código Civil, em casos de não caracterização da relação de consumo, em razão da especificidade da já histórica disciplina atinente aos vícios redibitórios.

Tratando-se de contratos coligados, como ocorre costumeiramente na incorporação imobiliária, e havendo cumprimento defeituoso quanto à obrigação de entregar coisa sem vícios, as consequências diferem: se o pleito for relativo à eliminação do vício ou à substituição da coisa, o contrato coligado, como de financiamento, não deve ser afetado; se, mediante ação estimatória, houver redução do preço da coisa, o valor devolvido deve ser encaminhado à instituição financeira que emprestou a quantia

\footnotetext{
${ }^{325}$ GUIMARÃES, Paulo Jorge Scartezzini. Vícios do produto e do serviço por qualidade, quantidade e insegurança: cumprimento imperfeito do contrato, cit., p. 215 e ss.

${ }^{326}$ É o que se verifica da segunda parte do art. 442 acima transcrito.

${ }^{327}$ REsp n ${ }^{\text {o }}$ 49868-PR. Rel. Salvio de Figueiredo Teixeira, julg. 14.05.91, $4^{\mathrm{a}}$ Turma.
} 
necessária, abatendo-se da dívida com o adquirente. Ainda, na hipótese da ação redibitória, entende-se que os contratos coligados devem ser extintos, pois um é a causa do outro ${ }^{328}$.

Previsão similar à de nosso direito está contida no direito italiano, em que se prevê a garantia do vendedor em relação aos vícios que tornem a coisa inidônea aos fins a que se destina ou que lhe reduzam o valor, sendo abarcados os vícios não conhecidos pelo comprador ou aqueles que não são facilmente perceptíveis, pois se conhecidos ou perceptíveis não geram a responsabilidade do vendedor ${ }^{329}$, como já mencionado.

No entanto, referido Código distingue os casos de vícios daqueles de falta de qualidade, definindo, no art. 1497, a hipótese em que a coisa entregue não possui a qualidade prometida ou qualidade essencial ao uso a que se destina, permitindo, em tal hipótese, a escolha pela resolução do contrato, com aplicação dos mesmos prazos indicados para casos de vícios ${ }^{330}$.

Lidia Savanna define que os vícios redibitórios são referentes a imperfeições inerentes ao processo de produção, fabricação, formação e conservação ou aqueles relacionados a imperfeições ou alterações da coisa, enquanto a falta de qualidade refere-se a elementos essenciais que condicionam a classificação da coisa em uma espécie determinada, podendo os vícios ser caracterizados quando não se tratar de falta de

\footnotetext{
${ }^{328}$ Conforme lição de GUIMARÃES, Paulo Jorge Scartezzini. Vícios do produto e do serviço por qualidade, quantidade e insegurança: cumprimento imperfeito do contrato, cit., p. 184. Tal entendimento mostra-se correto, uma vez que, com reparação ou substituição da coisa, a prestação do devedor se mantém igual, mas se houver redução do preço da coisa, a contraprestação deve ser alterada, equitativamente, afetando, pois o valor do financiamento. Igualmente, havendo resolução do contrato, as partes voltam ao estado anterior, "anulando", assim, o motivo do financiamento.

${ }^{329}$ Art. 1490 Garanzia per i vizi della cosa venduta - Il venditore è tenuto a garantire che la cosa venduta sia immune da vizi che la rendano inidonea all'uso a cui è destinata o ne diminuiscano in modo apprezzabile il valore. (...) Art. 1491 Esclusione della garanzia - Non è dovuta la garanzia (1490) se al momento del contratto il compratore conosceva i vizi della cosa; parimenti non è dovuta, se i vizi erano facilmente riconoscibili, salvo, in questo caso, che il venditore abbia dichiarato che la cosa era esente da vizi. Art. 1492 Effetti della garanzia - Nei casi indicati dall'art. 1490 il compratore può domandare a sua scelta la risoluzione del contratto (1453 e seguenti) ovvero la riduzione del prezzo, salvo, che, per determinati vizi, gli usi escludano la risoluzione. (...).

${ }^{330}$ Conforme art. 1497, cuja redação segue abaixo, a única possibilidade prevista seria a resolução, havendo, contudo, criticas a essa previsão, em razão do ideal de conservação dos contratos, conforme leciona Lidia Savanna em La compravendita garanzia per vizi della cosa venduta e nuova tutela del consumatore. Torino: Giappichelli, 2007. p. 32 e 119. Art. 1497 Mancanza di qualità - Quando la cosa venduta non ha le qualità promesse ovvero quelle essenziali per l'uso a cui è destinata, il compratore ha diritto di ottenere la risoluzione del contratto secondo le disposizioni generali sulla risoluzione per inadempimento (1453 e seguenti), purché il difetto di qualità ecceda i limiti di tolleranza stabiliti dagli usi.

Tuttavia il diritto di ottenere la risoluzione è soggetto alla decadenza e alla prescrizione stabilite dall'art. 1495 (att. 172).
} 
qualidade essencial do bem ou quando o defeito não for expressamente excluído pelas partes no contrato $^{331}$.

Ainda, tal autora ${ }^{332}$ cita a adequada distinção entre vícios e falta de qualidade das hipóteses de aliud pro alio ${ }^{333}$, em que o bem entregue seria completamente diverso, fosse de gênero diverso ou não tivesse capacidade funcional necessária a satisfazer os interesses do adquirente, informando-nos que, nesses casos, a consequência seria a prevista no art. 1453 do Código Civil italiano ${ }^{334}$.

Não obstante a conceituação, no direito italiano, do contrato preliminar como atípico, a tendência da jurisprudência italiana é equiparar o contrato preliminar ao definitivo de venda, na hipótese de existência de vícios ou deformidades da coisa entregue ${ }^{335}$.

Dessa forma, caberiam os remédios previstos para a compra e venda, qual sejam a redução de preço ou a determinação de obrigação de fazer consistente na eliminação do vício ${ }^{336}$, como alternativa à opção de resolver o contrato ${ }^{337}$,

${ }^{331}$ SAVANNA, Lidia. La compravendita garanzia per vizi della cosa venduta e nuova tutela del consumatore, cit., p. 27 e 31.

${ }^{332}$ SAVANNA, Lidia. La compravendita garanzia per vizi della cosa venduta e nuova tutela del consumatore, cit., p. 32 e ss.

${ }^{333}$ Trata-se da velha máxima nemo aliud pro alio invito creditore solvere potest, que está refletido no ar. 313 do Código Civil brasileiro e veda a liberação do devedor de coisa certa mediante entrega de coisa diversa da ajustada, mesmo que mais valiosa, conforme expõe Washington de Barros Monteiro em Curso de direito civil: direito das obrigações: $1^{\mathrm{a}}$ parte: das modalidades, das obrigações, dos efeitos das obrigações, do inadimplemento das obrigações, cit., p. 61.

334“Art. 1453. Risolubilità del contratto per inadempimento - Nei contratti con prestazioni corrispettive, quando uno dei contraenti non adempie le sue obbligazioni, l'altro può a sua scelta chiedere l'adempimento o la risoluzione del contratto $(1878,1976,2652)$, salvo, in ogni caso, il risarcimento del danno (1223 e seguenti).

La risoluzione può essere domandata anche quando il giudizio è stato promosso per ottenere l'adempimento; ma non può più chiedersi l'adempimento quando è stata domandata la risoluzione.

Dalla data della domanda (Cod. Proc. Civ. 163) di risoluzione l'inadempiente non può più adempiere la propria obbligazione.".

${ }^{335}$ CILENTO, Antonio. L'acquisto di immobili in costruzione tra rischio econômico e tutela della persona, cit., p. 35 e 37.

${ }^{336}$ Triola menciona entendimento jurisprudencial (Cass. 27 febbraio 1985, $\mathrm{n}^{\circ}$ 1720, in Giust. Civ., 1985, 1630) de que se garantem todos os remédios da norma geral relativa a inadimplemento nos casos de entrega de bem defeituoso ou com vícios, e, ainda, explana que tal medida representa restabelecimento do equilíbrio contratual, não sendo justificável a alegação de que o art. 1.492 do Código Civil italiano prevê esse remedio somente para a venda e na hipótese do contrato de empreitada de obra ou serviço previsto no art 1.668 (contrato de appalto). Ainda, explana que permitir que o juiz, na execução de obrigação de concluir o contrato definitivo, preveja a entrega de coisa com vício seria contraditório, pois o bem entregue não seria equivalente aquele compromissado. TRIOLA, Roberto. Vendita di immobili da costruire e tutela dell'acquirente, cit., p. 161-168.

${ }^{337}$ Veja-se entendimento da suprema corte italiana (Cass. 7, luglio 2000, no 9098, in Giust. Civ. Mass, 2000, p. 1517), que permitiu o pedido estimatório em caso de a ação principal resolutória ser julgada improcedente, sendo, o segundo pedido, assim, por via subordinada, não podendo, entretanto, o juiz julgar de forma contrária a escolha do credor. Conforme cita SAVANNA, Lidia. La compravendita garanzia per vizi della cosa venduta e nuova tutela del consumatore, cit., p. 124. 
sendo esta geradora de perdas e danos ${ }^{338}$.

Uma vez feita a escolha pelo adquirente, esta é irrevogável, por expressa previsão contida no art. 1.492 do Código Civil italiano.

Em relação ao ordenamento italiano, o art. 1.495 do Código Civil prevê, expressamente, o prazo decadencial de oito dias a contar do conhecimento do vício para o comprador reclamar ao vendedor e o prazo prescricional de um ano a contar da entrega da coisa ${ }^{339}$.

Triola menciona que o entendimento jurisprudencial italiano é no sentido de não se aplicar o exíguo prazo do art. 1.495, pois, para sua aplicação, pressupõe-se a transferência do direito sobre a coisa, o que não ocorre na existência de contrato preliminar. Contudo, o comportamento do adquirente ao utilizar o imóvel antes da transferência definitiva do direito sobre ele pode extinguir seu direito em relação à garantia aos vícios da coisa, considerando, exemplificativamente, o uso sem contestação quanto ao que recebeu, o que constituiria aceitação tácita ${ }^{340}$.

O legislador francês ampara, igualmente, os vícios ocultos como regra geral na venda $^{341}$. O art. 1.642-1 do Código Civil prevê que o vendedor de um edifício em

\footnotetext{
${ }^{338}$ Triola cita entendimento repetidamente exposto pela suprema Corte de que o valor do dano, nesse caso de resolução do contrato preliminar, por inadimplemento da obrigação de celebrar o contrato definitivo, e a diferença entre o valor pactuado para aquisição do imóvel e o valor do bem ao momento da propositura da acao, sem prejuízo da restituição de valores pagos pelo adquirente, com abatiamento de valores pelo uso e gozo do imóvel ate a resolução do contrato. TRIOLA, Roberto. Vendita di immobili da costruire e tutela dell'acquirente, cit., p. 187 e ss.

339“"Art. 1495 Termini e condizioni per l'azione - Il compratore decade dal diritto alla garanzia, se non denunzia i vizi al venditore entro otto giorni dalla scoperta (1511), salvo il diverso termine stabilito dalle parti o dalla legge.

La denunzia non è necessaria se il venditore ha riconosciuto l'esistenza del vizio o l'ha occultato.

L'azione si prescrive, in ogni caso, in un anno dalla consegna; ma il compratore, che sia convenuto per l'esecuzione del contratto, può sempre far valere la garanzia, purché il vizio della cosa sia stato denunziato entro otto giorni dalla scoperta e prima del decorso dell'anno dalla consegna (1522; att. 172)."

${ }^{340}$ TRIOLA, Roberto. Vendita di immobili da costruire e tutela dell'acquirente, cit., p. 173-176.

${ }^{341}$ Os arts. 1.641 a 1.649 tratam dos vícios ocultos, prevendo a responsabilidade pelos vícios que diminuam o valor da coisa, desde que não sejam aparentes ou pudessem ser verificados plo adquirente: "Art. 1641 - Le vendeur est tenu de la garantie à raison des défauts cachés de la chose vendue qui la rendent impropre à l'usage auquel on la destine, ou qui diminuent tellement cet usage que l'acheteur ne l'aurait pas acquise, ou n'en aurait donné qu'un moindre prix, s'il les avait connus."; "Article 1642 - Le vendeur n'est pas tenu des vices apparents et dont l'acheteur a pu se convaincre lui-même."; "Article 1643 - Il est tenu des vices cachés, quand même il ne les aurait pas connus, à moins que, dans ce cas, il n'ait stipulé qu'il ne sera obligé à aucune garantie."; "Article 1644 - Dans le cas des articles 1641 et 1643, l'acheteur a le choix de rendre la chose et de se faire restituer le prix, ou de garder la chose et de se faire rendre une partie du prix, telle qu'elle sera arbitrée par experts."; “ Article 1645 - Si le vendeur connaissait les vices de la chose, il est tenu, outre la restitution du prix qu'il en a reçu, de tous les dommages et intérêts envers l'acheteur."; "Article 1646 - Si le vendeur ignorait les vices de la chose, il ne sera tenu qu'à la restitution du prix, et à rembourser à l'acquéreur les frais occasionnés par la vente.".
} 
construção não pode se eximir da responsabilidade por vícios de construção aparentes ${ }^{342}$ nem antes da aceitação das obras, nem antes do decurso de um mês da imissão na posse pelo comprador $^{343}$, independentemente de ter o adquirente feito reserva ou não no momento do recebimento ${ }^{344}$.

Pelo segundo parágrafo de tal artigo, permite-se a reparação do vício ou a resolução do contrato ou abatimento do preço. Entende-se também pela possibilidade de reparação do vício ${ }^{345}$, considerando-se que citado parágrafo permite que o vendedor se ofereça para tomar essa providência.

No caso de imóvel em construção, o adquirente pode, portanto, pleitear a resolução do contrato ou o abatimento do preço, desde que o vendedor não possa ou não queira reparar o vício. Entretanto, o art. 1.644, referente a qualquer venda, prevê somente a possibilidade de redibir o contrato ou obter a redução do preço, devendo haver arbitramento por terceiro quanto ao preço.

A ação do adquirente deve ser intentada no prazo previsto no art. 1.648 do Código Civil francês, sendo de dois anos da entrega ou treze meses da imissão na posse.

Cabe avaliar a natureza jurídica dos prazos atinentes aos vícios redibitórios no direito brasileiro, havendo entendimento de que se trata de prazo decadencial ${ }^{346}$

\footnotetext{
${ }^{342}$ Ressalte-se que a regra geral relativa a essa garantia está contida no art. 1.625 do Código Civil francês: "La garantie que le vendeur doit à l'acquéreur a deux objets : le premier est la possession paisible de la chose vendue ; le second, les défauts cachés de cette chose ou les vices rédhibitoires.".

${ }^{343}$ Interpretação literal da autora, conforme texto original: "Le vendeur d'un immeuble à construire ne peut être déchargé, ni avant la réception des travaux, ni avant l'expiration d'un délai d'un mois après la prise de possession par l'acquéreur, des vices de construction alors apparents.

Il n'y aura pas lieu à résolution du contrat ou à diminution du prix si le vendeur s'oblige à réparer le vice.".

${ }^{344}$ LUCHEUX, Jean-Michel. Les garanties de l'acquéreur dans les ventes d'immeubles à construire. [S.1.]: L'auteur, 1968. p. 161.

${ }^{345}$ Conforme ementa exposta em Cour de Cassation Chambre civile 3 Audience publique du 2 mars 2005 N $^{\circ}$ de pourvoi: 03-19208 (Cass 3 civ. 2-3-2005 n 03-19.208): “CONSTRUCTION IMMOBILIERE Immeuble à construire - Vendeur - Obligations - Garantie des vices apparents - Mise en oeuvre Réparation - Modalités. Viole l'article 1642-1 du Code civil la cour d'appel qui retient que cet article ne prévoit que la résolution de la vente ou la diminution du prix alors que le vice de construction apparent peut faire l'objet d'une réparation en nature ou en équivalent et d'un dédommagement du préjudice de jouissance ayant pu découler de ce vice.».

${ }^{346}$ Segundo Scartezzini, trata-se de prazo decadencial, pois para exercer o direito em si é necessária a propositura das ações citadas no prazo previsto para tanto. GUIMARÃES, Paulo Jorge Scartezzini. Vícios do produto e do serviço por qualidade, quantidade e insegurança: cumprimento imperfeito do contrato, cit., p. 305. Da mesma forma, PEREIRA, Caio Mário da Silva. Instituições de direito civil: contratos, cit., v. 3, p. 109. Agnelo Amorim Filho, baseando-se a classificação das ações judiciais, entende que para determinadas opções (para abatimento do preço ou para reaver preço pago, mais perdas e danos, em caso de redibição) seria prazo prescricional, pois seriam ações condenatórias, e para a redibição em si, seria decadencial, pois ação constitutiva, devendo, para ele, a caracterização de prazo decadencial prevalecer, por ter este conteúdo de interesse público maior. AMORIM FILHO, Agnelo. Critério científico para distinguir
} 
ou de prazo prescricional ${ }^{347}$.

Deve-se esclarecer, oportunamente, que o Código Civil sistematizou a prescrição e a decadência, reunindo os prazos prescricionais na parte geral do Código, nos artigos $205^{348}$ e $206^{349}$, sendo que os demais prazos espalhados no Código seriam de decadência ${ }^{350}$.

Pela literalidade do art. $445^{351}$ do Código Civil, que fixa o prazo de trinta dias para coisas móveis e de um ano para imóveis para o adquirente obter a redibição ou o abatimento do preço sob pena de decair de seu direito, trata-se de prazo decadencial.

Observe-se, ainda, que o anterior Código Civil previa expressamente que o prazo para obter a redibição do contrato ou o abatimento do preço era prescricional ${ }^{352}$, o que reitera que o atual prazo é decadencial, parecendo que o legislador corrigiu um equívoco ao excluir aludidos prazos do artigo atual que trata da prescrição.

De acordo com o art. 445 citado, em regra, o prazo é contado a partir da entrega da coisa, podendo tais prazos ser reduzidos à metade, caso o adquirente já esteja na posse do bem, uma vez que teve mais tempo para verificar o vício.

O parágrafo $1^{\circ}$ do art. 445 traz outros $\operatorname{prazos}^{353}$, que se referem aos prazos máximos para conhecimento dos vícios, a partir da data de entrega da coisa, sendo de cento e oitenta dias para coisas móveis e de um ano para coisas imóveis.

a prescrição da decadência e para identificar as ações imprescritíveis. In: BARBOSA MOREIRA, José Carlos (Coord.). Revista Forense Comemorativa: 100 anos: direito processual civil. Rio de Janeiro: Forense, 2006. t. 5, p. 119. Veja, ainda, a existência do Enunciado no 28 da I Jornada de Direito Civil do Conselho da Justiça Federal: "Art. $445\left(\S \S 1^{\circ}\right.$ e $\left.2^{\circ}\right)$ : O disposto no art. 445 , $\S \S 1^{\circ}$ e $2^{\circ}$, do Código Civil reflete a consagração da doutrina e da jurisprudência quanto à natureza decadencial das ações edilícias.".

${ }^{347}$ MONTEIRO DE BARROS, Washington. Curso de direito civil: direito das obrigações, cit., v. 5, 2 pt., p. 51.

348، “Art. 205. A prescrição ocorre em dez anos, quando a lei não lhe haja fixado prazo menor.”.

349،“Art. 206. Prescreve: $\S 1^{\circ} \mathrm{Em}$ um ano: I - a pretensão dos hospedeiros ou fornecedores de víveres destinados a consumo no próprio estabelecimento, para o pagamento da hospedagem ou dos alimentos; II a pretensão do segurado contra o segurador, ou a deste contra aquele, contado o prazo: (...).".

${ }^{350}$ ANDRADE, Fabio Siebeneichler. Considerações sobre o regime da prescrição no Código Civil de 2002 e seus efeitos quanto à Lei de Defesa do Consumidor. In: PFEIFFER, Roberto Augusto Castellanos; PASQUALOTTO, Adalberto (Coords.). Código de Defesa do Consumidor e o Código Civil de 2002: convergências e assimetrias. São Paulo: Ed. Revista dos Tribunais, 2005. p. 305.

351 '“Art. 445. O adquirente decai do direito de obter a redibição ou abatimento no preço no prazo de trinta dias se a coisa for móvel, e de um ano se for imóvel, contado da entrega efetiva; se já estava na posse, o prazo conta-se da alienação, reduzido à metade.”.

352، Art. 178. Prescreve: (...) $§ 2^{\circ}-$ Em 15 (quinze) dias, contados da tradição da coisa, a ação para haver abatimento do preço da coisa móvel, recebida com vício redibitório, ou para rescindir o contrato e reaver o preço pago, mais perdas e danos."

353، $\$ 11^{\circ}$ Quando o vício, por sua natureza, só puder ser conhecido mais tarde, o prazo contar-se-á do momento em que dele tiver ciência, até o prazo máximo de cento e oitenta dias, em se tratando de bens móveis; e de um ano, para os imóveis." 
Esse prazo é comumente visto como benéfico às relações contratuais, por evitar o receio eterno do vendedor de ser chamado em razão da existência de vícios na coisa, oferecendo-se, assim, maior segurança a tais relações ${ }^{354}$.

$\mathrm{O}$ art. $446^{355}$, por sua vez, prevê que os prazos do art. 445 não correrão durante a vigência de prazo de garantia estipulado em contrato, mas, surgindo o defeito, o adquirente deve denunciar ao alienante o defeito verificado ${ }^{356}$, no prazo de trinta dias após seu descobrimento, sob pena de perder seu direito.

Ressalte-se que o art. $207^{357}$ indica que para a decadência não se aplicam as regras de interrupção e suspensão da prescrição, exceto se houver disposição legal em contrário, sendo o art. 446 disposição legal que define que tal prazo não correrá ${ }^{358}$.

Ainda, compete mencionar que se entende que a responsabilidade pelos vícios redibitórios pode ser aumentada ou reduzida, conforme acordo entre as partes ${ }^{359}$.

Por fim, no tocante ao ônus probatório, vale ressaltar que, de acordo com o art. 333, I, do Código de Processo Civil brasileiro, ao autor incumbe a prova em relação ao fato constitutivo de seu direito, devendo o adquirente, assim, provar a existência de vício oculto, havendo presunção relativa de ser o vício anterior à tradição da coisa em razão do curto prazo para propositura da ação, na lição de Romano Martinez ${ }^{360}$.

\footnotetext{
${ }^{354}$ Conforme GUIMARÃES, Paulo Jorge Scartezzini. Vícios do produto e do serviço por qualidade, quantidade e insegurança: cumprimento imperfeito do contrato, cit., p. 308 e PEREIRA, Caio Mário da Silva. Instituições de direito civil: contratos, cit., v. 3, p. 110, que definem que não quis o legislador manter indefinidamente a regra de garantia nas hipóteses em que o vício se conhece depois, como o art. 26, parágrafo $3^{\circ}$, do Código de Defesa do Consumidor.

${ }^{355}$ Art. 446. Não correrão os prazos do artigo antecedente na constância de cláusula de garantia; mas o adquirente deve denunciar o defeito ao alienante nos trinta dias seguintes ao seu descobrimento, sob pena de decadência.

${ }^{356}$ Pode-se interpretar que, como o adquirente deve denunciar o vício ao alienante, não se trata de prazo para o ingresso de ação, mas para comunicação.

357“"Art. 207. Salvo disposição legal em contrário, não se aplicam à decadência as normas que impedem, suspendem ou interrompem a prescrição.”. Tal linha é prevista também nos Códigos civis português e italiano, que permitem, nos arts. 328 e 2965 respectivamente, a suspensão do prazo decadencial se houver previsão legal nesse sentido.

${ }^{358}$ Igualmente, o art. 208 prevê que se aplicam à decadência as disposições do art. 198, I, do Código Civil, que prevê que "Também não corre a prescrição: I - contra os incapazes de que trata $\mathrm{o}$ art. $3^{\circ}$ ".

${ }^{359}$ PONTES DE MIRANDA, Francisco Cavalcanti. Tratado de direito privado: parte especial, cit., t. 38, p. 286, e BESSA, Leonardo Roscoe. Vícios dos produtos: paralelo entre o CDC e o Código Civil, cit., p. 281.

${ }^{360}$ MARTINEZ, Pedro Romano. Cumprimento defeituoso: em especial na compra e venda e na empreitada, cit., p. 358. Esse entendimento, em relação ao direito italiano, também é esposado por Savanna, que indica que o comprador deve provar a existência ou preexistência do vício em relação ao momento do contrato. SAVANNA, Lidia. La compravendita garanzia per vizi della cosa venduta e nuova tutela del consumatore, cit., p. 53.
} 


\subsection{Regulação pelo Código de Defesa do Consumidor}

A responsabilidade no Código de Defesa do Consumidor não se limita à contratual, uma vez que há responsabilidade de terceiros que não são partes de contratos e em favor de terceiros, como os consumidores equiparados.

Os vícios considerados por tal Código são aqueles por inadequação (art. $18^{361}$ ) ou por insegurança (art. $12^{362}$ ), referindo-se, pois, às hipóteses de vícios e às hipóteses de fato do produto, além dos vícios atinentes aos serviços prestados, no art. $14^{363}$.

Os vícios abrangidos no art. 18 do Código em questão são os de qualidade ou quantidade que tornem os produtos impróprios ou inadequados ao consumo a que se destinam ou lhes diminuam o valor, sendo que aqueles incluem, segundo Cláudia Lima Marques, os vícios de impropriedade, os de diminuição o valor e de disparidade informativa (por falha na informação ${ }^{364}$ ), indicados no art. $19^{365}$, sendo relevante para apurar a diferença de quantidade as informações da publicidade ou da embalagem ${ }^{366}$.

\footnotetext{
361“'Art. 18. Os fornecedores de produtos de consumo duráveis ou não duráveis respondem solidariamente pelos vícios de qualidade ou quantidade que os tornem impróprios ou inadequados ao consumo a que se destinam ou lhes diminuam o valor, assim como por aqueles decorrentes da disparidade, com a indicações constantes do recipiente, da embalagem, rotulagem ou mensagem publicitária, respeitadas as variações decorrentes de sua natureza, podendo o consumidor exigir a substituição das partes viciadas.".

362“Art. 12. O fabricante, o produtor, o construtor, nacional ou estrangeiro, e o importador respondem, independentemente da existência de culpa, pela reparação dos danos causados aos consumidores por defeitos decorrentes de projeto, fabricação, construção, montagem, fórmulas, manipulação, apresentação ou acondicionamento de seus produtos, bem como por informações insuficientes ou inadequadas sobre sua utilização e riscos. $\S 1^{\circ} \mathrm{O}$ produto é defeituoso quando não oferece a segurança que dele legitimamente se espera, levando-se em consideração as circunstâncias relevantes, entre as quais: (...).". Acerca de defeito, Rizzato Nunes revela, com razão, que o vício está adstrito à coisa ou ao serviço e o defeito, que é vício também, ocasiona danos de forma extrínseca ao produto ou ao serviço. (RIZZATO NUNES, Luiz Antonio. Comentários ao Código de Defesa do Consumidor. 4. ed. São Paulo: Saraiva, 2009. p. 183).

363،AArt. 14. O fornecedor de serviços responde, independentemente da existência de culpa, pela reparação dos danos causados aos consumidores por defeitos relativos à prestação dos serviços, bem como por informações insuficientes ou inadequadas sobre sua fruição e riscos. $\S 1^{\circ} \mathrm{O}$ serviço é defeituoso quando não fornece a segurança que o consumidor dele pode esperar, levando-se em consideração as circunstâncias relevantes, entre as quais: (...).”.

${ }^{364}$ Ressalte-se que a questão da informação aos consumidores quanto aos produtos e serviços é elemento essencial do Código de Defesa do Consumidor, conforme se depreende de seu art. $6^{\circ}$, III , que define que, entre outros, é direito básico do consumidor a informação adequada e clara sobre os produtos e serviços, com especificação correta de quantidade, características, composição, qualidade e preço, bem como sobre os riscos que apresentem, bem como a proteção contra a publicidade enganosa e abusiva, conforme a seguinte redação: “Art. $6^{\circ}$ São direitos básicos do consumidor: (...) III - a informação adequada e clara sobre os diferentes produtos e serviços, com especificação correta de quantidade, características, composição, qualidade, tributos incidentes e preço, bem como sobre os riscos que apresentem;(...)".

365“Art. 19. Os fornecedores respondem solidariamente pelos vícios de quantidade do produto sempre que, respeitadas as variações decorrentes de sua natureza, seu conteúdo líquido for inferior às indicações constantes do recipiente, da embalagem, rotulagem ou de mensagem publicitária, (...).”.

${ }^{366}$ Claudia Lima Marques inclui essa disparidade como vício de qualidade por falha na informação. Contratos no Código de Defesa do Consumidor: o novo regime das relações contratuais, cit., p. 1221.
} 
Tem-se que o Código de Defesa do Consumidor baseou-se na teoria da qualidade, de forma que os vícios sejam classificados em qualitativos e quantitativos, independentemente da discussão da existência ou não de culpa no serviço ou no fornecimento do bem ${ }^{367}$.

Assim, os fornecedores devem garantir que os produtos colocados no mercado servirão para os fins propostos, sem vícios ou defeitos.

Lydia Neves Bastos Telles Nunes ${ }^{368}$ cita que as exigências para proteção dos vícios redibitórios constantes do Código Civil teriam sido amenizadas pelo Código de Defesa do Consumidor, dando maior proteção ao consumidor.

O art. 18 de mencionado Código, por exemplo, repete de certa forma a redação do art. 441 do Código Civil, mas vai além e aponta como viciosos os produtos que apresentem disparidade em relação às indicações constantes do recipiente, da embalagem, rotulagem ou mensagem publicitária, podendo o consumidor exigir a substituição das partes viciadas.

Outras diferenças entre as disposições do Código Civil e as do Código de Defesa do Consumidor podem ser verificadas.

No Código de Defesa do Consumidor, abarcam-se os vícios de pequena monta, não havendo importância a relação entre o defeito e a totalidade do bem, não sendo relevante a gravidade do vício.

Os vícios podem ser ocultos ou aparentes, não importando a ciência do fornecedor, por se tratar de dever legal de não colocar no mercado produto ou serviço com vício ou defeito, havendo previsão específica quanto ao prazo decadencial para vícios ocultos e para os de fácil constação, nos artigos 26 e 27, que serão melhor analisados.

Como o Código de Defesa do Consumidor abarca os vícios aparentes, pode-se argumentar da desnecessidade de o adquirente ressalvar expressamente no termo de recebimento de chaves os vícios aparentes verificados, o que não obsta a pertinência de tal medida para proteção do adquirente.

\footnotetext{
${ }^{367}$ Jorge cesa, p. 191 e MARQUES, Claudia de Lima. Contratos no Código de Defesa do Consumidor: o novo regime das relações contratuais, cit., p. 1207.

${ }^{368}$ NUNES, Lydia Neves Bastos Telles. Dos efeitos dos vícios redibitórios à luz do Código Civil brasileiro e do Código de Defesa do Consumidor. Revista do Instituto de Pesquisas e Estudos, Bauru/SP, n. 29, p. 69$82,2000$.
} 
Há o alargamento do sujeito ativo, em razão das solidariedades previstas em tal código $^{369}$ e da responsabilidade de todas as partes na cadeia de fornecimento de bens como fornecedores, bem como o alargamento do sujeito passivo, por haver proteção dos adquirentes futuros, uma vez que o art. $2^{\circ}$, que define o consumidor, faz referência não somente ao adquirente, como também ao usuário, além de haver, no art. $29^{370}$, a equiparação a consumidor de todos aqueles expostos às práticas nele previstas.

Outras diferenças são observadas no tocante às consequências do vício.

A solução inicial no Código de Defesa do Consumidor é o reparo da coisa, que, nos termos do art. 18, parágrafo $1^{\circ}$ e incisos, deve ser realizado no prazo de trinta dias, podendo citado prazo variar de sete a cento e oitenta dias, conforme se convencionar, nos termos do parágarafo segundo de tal artigo ${ }^{371}$.

Ressalte-se haver entendimento no sentido de ser necessária a concessão do prazo para reparo ou substituição das partes viciadas ${ }^{372}$.

Pela literalidade da lei, parece-nos se tratar de direito do consumidor, podendo ou não exigir a substituição das partes viciadas ${ }^{373}$. Contudo, tendo o legislador cogitado a habilidade do fornecedor nesse sentido, bem como as hipóteses em que tal reparo seria descartado de pronto $^{374}$, trata-se de medida eficaz para se obter uma solução amigável, pois

\footnotetext{
${ }^{369}$ Como previsto no art. 18 , já citado; no parágrafo primeiro do art 25 , no que se refere a vício de produto ou serviço ("§ $1^{\circ}$ Havendo mais de um responsável pela causação do dano, todos responderão solidariamente pela reparação prevista nesta e nas seções anteriores"); no parágrafo único do art. $7^{\circ}$ ("Parágrafo único. Tendo mais de um autor a ofensa, todos responderão solidariamente pela reparação dos danos previstos nas normas de consumo."; no próprio art. 12, que define a responsabilidade do fabricante, produtor, construtor e importador; e no art. 13, que também se refere ao fato do produto, e coloca o comerciante como responsável em determinadas hipóteses ("Art. 13. O comerciante é igualmente responsável, nos termos do artigo anterior, quando: I - o fabricante, o construtor, o produtor ou o importador não puderem ser identificados; II - o produto for fornecido sem identificação clara do seu fabricante, produtor, construtor ou importador;III - não conservar adequadamente os produtos perecíveis.").

${ }^{370}$ Art. 29. Para os fins deste Capítulo e do seguinte, equiparam-se aos consumidores todas as pessoas determináveis ou não, expostas às práticas nele previstas.".

${ }^{371} \S 2^{\circ}$ Poderão as partes convencionar a redução ou ampliação do prazo previsto no parágrafo anterior, não podendo ser inferior a sete nem superior a cento e oitenta dias. Nos contratos de adesão, a cláusula de prazo deverá ser convencionada em separado, por meio de manifestação expressa do consumidor.

${ }^{372}$ Conforme CAVALIERI FILHO, Sergio. Programa de direito do consumidor, cit., p. 268.

${ }^{373}$ Bessa entende que somente em situações excepcionais poderá ser invocado o prazo de 30 dias. BESSA, Leonardo Roscoe. Vícios dos produtos: paralelo entre o CDC e o Código Civil, cit., p. 291.

${ }^{374}$ As quais estão listadas no parágrafo $3^{\circ}$ do art. 18 , a saber: "§ $3^{\circ} \mathrm{O}$ consumidor poderá fazer uso imediato das alternativas do $\S 1^{\circ}$ deste artigo sempre que, em razão da extensão do vício, a substituição das partes viciadas puder comprometer a qualidade ou características do produto, diminuir-lhe o valor ou se tratar de produto essencial.". Apresentam-se critérios subjetivos, exceto se houver dados realistas, de peritos, indicando que houve de fato comprometimento ou diminuição de valor etc. "§ $3^{\circ} \mathrm{O}$ consumidor poderá fazer uso imediato das alternativas do $\S 1^{\circ}$ deste artigo sempre que, em razão da extensão do vício, a substituição das partes viciadas puder comprometer a qualidade ou características do produto, diminuir-lhe o valor ou se tratar de produto essencial.".
} 
pode garantir o pleno funcionamento do bem pelo adquirente e pode significar para o fornecedor uma solução mais rápida e econômica.

Discute-se na doutrina, ainda, se o fornecedor tem a oportunidade de tentar consertar diversas vezes a coisa ou se a prerrogativa dada pelo Código de Defesa do Consumidor é exercitável apenas uma vez.

O fornecedor deve ter direito ao reparo da coisa, mas tal direito deve ser limitado a uma vez, para evitar maiores prejuízos ao consumidor causados pelo decurso do tempo, até mesmo porque se trata de direito do consumidor, e, dada essa possibilidade, o fornecedor não pode se aproveitar, alargando prazo para definitiva solução ${ }^{375}$.

Não sendo sanado o vício no prazo indicado, ao consumidor abre-se a possibilidade de escolher entre a substituição do produto por outro da mesma espécie e sem vício; a restituição da quantia paga, sem prejuízo de eventuais perdas e danos; e o abatimento proporcional do preço ${ }^{376}$.

A substituição do bem por outro sem vícios, em casos de imóveis, é extremamente difícil, pois, em um empreendimento, se um imóvel possui vício é muito possível que todos os outros apresentem os mesmos vícios, além de ser uma coisa não disponível em estoque.

Outras soluções são o abatimento proporcional do preço, com a manutenção do negócio $^{377}$, e o desfazimento do negócio com a restituição imediata da quantia paga com indenização por perdas e danos.

Deve-se observar atentamente que o Código de Defesa do Consumidor só menciona a ressalva ao pleito por eventuais perdas e danos nos casos em que há desfazimento do contrato, o que também é previsto no art. 20, que se refere a vícios dos serviços ${ }^{378}$.

\footnotetext{
${ }^{375}$ Rizzato Nunes entende que o fornecedor pode reparar mais de uma vez, desde que dentro do prazo de 30 dias. RIZZATO NUNES, Luiz Antonio. Comentários ao Código de Defesa do Consumidor, cit., p. 251.

376“'Art. 18 (...) $\$ 1^{\circ}$ Não sendo o vício sanado no prazo máximo de trinta dias, pode o consumidor exigir, alternativamente e à sua escolha: I - a substituição do produto por outro da mesma espécie, em perfeitas condições de uso; II - a restituição imediata da quantia paga, monetariamente atualizada, sem prejuízo de eventuais perdas e danos; III - o abatimento proporcional do preço."

${ }^{377}$ Trata-se de novo mandamento geral para os contratos, que se justifica atualmente, principalmente no âmbito da nota teoria contratual do século XX, positivada no Código de Defesa do Consumidor e no Código Civil de 2002. Para maiores explanações, ver MARQUES, Claudia de Lima. Contratos no Código de Defesa do Consumidor: o novo regime das relações contratuais, cit., p. 297.

378، “Art. 20. O fornecedor de serviços responde pelos vícios de qualidade (...) podendo o consumidor exigir, alternativamente e à sua escolha: I - a reexecução dos serviços, sem custo adicional e quando cabível; II - a restituição imediata da quantia paga, monetariamente atualizada, sem prejuízo de eventuais perdas e danos; III - o abatimento proporcional do preço.”.
} 
Trata-se de desarrazoada medida, uma vez que a indenização por perdas e danos não deve ser afastada em nenhum caso, determinando-se, inclusive, tal possibilidade em simples caso de mora, nos termos das regras civis ${ }^{379}$.

Explicação, contudo, pode existir, se se entender que, havendo danos extrínsecos à coisa, tratar-se-á de fato do produto ou serviço, que enseja a aplicação do prazo do art. 27.

Em relação aos serviços, tem-se que o Código de Defesa do Consumidor inovou ao introduzir a noção de vício do serviço, uma vez que a lei civil previa a figura do vício redibitório apenas em contratos relacionados à entrega da coisa, aplicando-se, contudo, as regras civis, como as atinentes às obrigações de fazer e ao inadimplemento ${ }^{380}$.

O Código de Defesa do Consumidor, nesse sentido, determina, pelo resultado dos serviços, e de acordo com natureza da obrigação, se há vício resultante em impropriedade ${ }^{381}$ dos serviços prestados ou diminuição de seu valor, nos termos do citado art. 20.

Veja-se que aludido artigo prevê as seguintes opções ao consumidor: a reexecução dos serviços, sem custo adicional e quando cabível; a restituição da quantia paga, sem prejuízo de eventuais perdas e danos; e o abatimento proporcional do preço.

Obviamente, não podia prever o legislador a substituição do serviço, como o fez em relação a vícios de produtos, havendo previsão de reexecução dos serviços, para sua adequação, sem estipulação de prazo para tanto.

Os demais remédios não diferem do já analisados.

Ressalte-se que o Código de Defesa do Consumidor trata da garantia legal ${ }^{382}$, aplicável a todos os fornecedores, tendo por fim o cumprimento perfeito da prestação

\footnotetext{
${ }^{379}$ Nesse sentido, Pontes de Miranda explana que a pretensão de indenização não se confunde com a pretensão à responsabilidade por vícios do objeto. Tratado de direito privado: parte especial, cit., t. 38, p. 306. Tal doutrina enseja, obviamente, o entendimento de que os prazos previstos nos artigos que se referem aos vícios redibitórios ou vícios do produtolserviço do Código de Defesa do Consumidor não podem ser aplicados para as ações que buscam indenização por danos causados.

${ }^{380}$ Veja-se entendimento de Claudia Lima Marques: "Não que no sistema do direito civil tradicional não existisse remédio jurídico para a falha na execução do serviço contratado - simplesmente o caso era considerado como inadimplemento contratual e não como vício redibitório.”. MARQUES, Claudia de Lima. Contratos no Código de Defesa do Consumidor: o novo regime das relações contratuais, cit., p. 1223.

${ }^{381}$ A definição de impropriedade dos serviços consta do parágrafo $2^{\circ}$ do art. 20 : "§ $2^{\circ}$ São impróprios os serviços que se mostrem inadequados para os fins que razoavelmente deles se esperam, bem como aqueles que não atendam as normas regulamentares de prestabilidade.".

${ }^{382}$ Art. 24. A garantia legal de adequação do produto ou serviço independe de termo expresso, vedada a exoneração contratual do fornecedor.
} 
e o reequilíbrio da relação de consumo, e da garantia contratual ${ }^{383}$, considerada como adicional àquela.

Há, assim, para o fornecedor, o dever legal de não colocar no mercado produto viciado ou defeituoso. Se o fizer, deverá se responsabilizar por isso, nos termos do código em questão.

No tocante aos prazos, o termo inicial do prazo decadencial, para vícios de produtos e serviços, é a data de ciência do vício e não a da entrega da coisa ${ }^{384}$.

O instituto da decadência tratada no art. $26^{385}$ é de fácil ponderação: para o caso de vícios aparentes nos serviços ou produtos, para aqueles não duráveis o prazo será de trinta dias; e, para o caso de produto ou serviço durável, de noventa dias.

Contudo, o prazo para os produtos ou serviços que apresentarem vícios ocultos, será contado normalmente, de acordo com o tipo durável ou não durável de produto ou serviço, porém a partir da evidência do vício, conforme parágrafo $3^{\text {o386 }}$.

Nos termos do parágafo $2^{\circ}$ do artigo 26 , o prazo decadencial será obstado a partir da reclamação formal contra o fornecedor até a resposta negativa por este, comunicada ao consumidor de maneira inequívoca; ou ainda pela instauração de inquérito civil pelo Ministério Público, até seu encerramento.

Outra discussão é acerca da obstaculização dos prazos, especialmente se o Código em questão se refere à interrupção ou à suspensão de citados prazos, merecendo acolhimento a tese de que se trata de interrupção, por se tratar de prazo exíguo e por ser a tese que melhor atende aos interesses do consumidor ${ }^{387}$.

\footnotetext{
${ }^{383}$ Art. 50. A garantia contratual é complementar à legal e será conferida mediante termo escrito.

${ }^{384}$ Conforme parágrafo primeiro do art $26:$ : $\$ 11^{\circ}$ Inicia-se a contagem do prazo decadencial a partir da entrega efetiva do produto ou do término da execução dos serviços.".

385“Art. 26. O direito de reclamar pelos vícios aparentes ou de fácil constatação caduca em: I - trinta dias, tratando-se de fornecimento de serviço e de produtos não duráveis; II - noventa dias, tratando-se de fornecimento de serviço e de produtos duráveis.".

${ }^{386}$ Que tem a seguinte redação: “\$ $3^{\circ}$ Tratando-se de vício oculto, o prazo decadencial inicia-se no momento em que ficar evidenciado o defeito.”.

${ }^{387}$ Scartezzini cita doutrina que prevê que as causas suspensivas independem da vontade das partes e que as interruptivas, ao contrário, dependem da vontade das partes, sendo por elas provocadas. Assim, em caso de reclamação direta do consumidor, haveria interrupção a partir da reclamação ao fornecedor e até o recebimento da negativa dada por este ao consumidor. Entretanto, na outra hipótese prevista no Código de Defesa do Consumidor, de abertura de inquérito civil pelo Ministério Público, como se trata de ação que independe do consumidor, haveria suspensão. GUIMARÃES, Paulo Jorge Scartezzini. Vícios do produto e do serviço por qualidade, quantidade e insegurança: cumprimento imperfeito do contrato, cit., p. 313.
} 
Cláudia Lima Marques entende que a regra do art. 26 refere-se a decadência do direito de reclamar judicialmente, ou seja, "decadência do direito à satisfação contratual perfeita",388.

Essa posição parece carecer de razão, pela exiguidade do prazo para propositura de uma ação judicial, e pela vulnerabilidade dos consumidores, que pouco acesso, muitas das vezes, têm ao Judiciário. Assim, mais viável entendimento de que em tal prazo deve o consumidor reclamar ao fornecedor, de forma a assegurar sua proteção, atingindo-se o objetivo do Código de Defesa do Consumidor.

O art. $27^{389}$ refere-se à prescrição da pretensão à reparação pelos danos causados, em caso de fato do produto ou serviço, e estabelece o prazo para o direito de ação de cinco anos a partir do conhecimento do dano e sua autoria.

O entendimento, pela literalidade da norma, é de que o prazo inicia somente quando o consumidor conhece o dano e o autor, podendo, por exemplo, o consumidor conhecer o dano, porém não conhecer o autor.

Ressalte-se divergência doutrinária quanto ao limite para surgimento ou conhecimento do vício ${ }^{390}$, sendo pertinente a interpretação de que, pela especificidade do Código de Defesa do Consumidor no que se refere à proteção concedida ao mercado de consumo no geral, proibindo-se a introdução de bens e serviços viciados ou defeituosos, não deve haver prazo limite para seu aparecimento, devendo-se considerar a vida útil do bem. Tal medida não deve criar insegurança aos fornecedores, mas maior cuidado e zelo ao se lançar produto ou serviço no mercado.

Verifica-se, pois, que o Código de Defesa do Consumidor, além de alargar a proteção ao consumidor, em razão dos pressupostos básicos da teoria em que se basearam

\footnotetext{
${ }^{388}$ MARQUES, Claudia de Lima. Contratos no Código de Defesa do Consumidor: o novo regime das relações contratuais, cit., p. 1244.

${ }^{389}$ Art. 27. Prescreve em cinco anos a pretensão à reparação pelos danos causados por fato do produto ou do serviço prevista na Seção II deste Capítulo, iniciando-se a contagem do prazo a partir do conhecimento do dano e de sua autoria.

${ }^{390}$ Scartezzini sustenta que, ainda que o Código de Defesa do Consumidor não preveja prazo limite, deve-se aplicar subsidiariamente as regras do Código Civil, de forma que haja maior segurança também nessas relações. GUIMARÃES, Paulo Jorge Scartezzini. Vícios do produto e do serviço por qualidade, quantidade e insegurança: cumprimento imperfeito do contrato, cit., p. 314. Entendimento contrário é o de Claudia Lima Marques, que entende se tratar de garantia pelo prazo de vida útil do bem, se se tratar de vícios oculto, e, sendo vício aparente, "seus limites serão de 30 ou 90 dias da entrega efetiva do produto ou do término dos serviços, bastando que o consumidor reclame perante o fornecedor ou perante o Ministério Público, para obstar a decadência de seu direito". MARQUES, Claudia de Lima. Contratos no Código de Defesa do Consumidor: o novo regime das relações contratuais, cit., p. 1253.
} 
os legisladores ao elaborarem referido código, traz previsões mais benéficas em relação ao Código Civil, como a abrangência de vícios aparentes, a possibilidade de substituição do bem, a vedação a estipulação contratual que impossibilite, exonere ou atenue a obrigação de indenizar o consumidor em caso de fato ou vícios do produto ou serviço ${ }^{391}$, a ausência de prazo limite para aparecimento do vício, e a responsabilidade objetiva.

Condição desfavorável ao consumidor-adquirente, entretanto, é o prazo de decadência para coisas duráveis, como o imóvel, sendo de apenas noventa dias, quando o Código Civil prevê, para esse tipo de bem, o prazo de um ano.

Nesse contexto, há de se ressaltar que as normas do Código de Defesa do Consumidor são caracterizadas como de ordem pública, afastando a possibilidade de se afastar ou se atenuar a garantia dele constante.

Ainda que suas previsões não possam ser afastadas, deve-se observar as normas mais específicas, como antes mencionado. Não existindo na norma mais específica, que seria a Lei de Incorporação Imobiliária, previsão quanto aos vícios, deve-se interpretar as normas "conflitantes"392.

Tratando-se de relação de consumo, ainda que haja previsão de que outros direitos previstos em outras normas não são excluídos pelo Código de Defesa do Consumidor, a busca da norma mais benéfica, com aplicação de regulações diferentes, parece ser medida excessiva.

Deve haver, assim, lógica estrutural na base dos pleitos, seguindo-se, preferencialmente, as normas do Código Civil ou do Código de Defesa do Consumidor, sem conjunção.

\footnotetext{
${ }^{391}$ Como se depreende do arts. 25 e 51, I: "Art. 25. É vedada a estipulação contratual de cláusula que impossibilite, exonere ou atenue a obrigação de indenizar prevista nesta e nas seções anteriores." e "Art. 51. São nulas de pleno direito, entre outras, as cláusulas contratuais relativas ao fornecimento de produtos e serviços que: I - impossibilitem, exonerem ou atenuem a responsabilidade do fornecedor por vícios de qualquer natureza dos produtos e serviços ou impliquem renúncia ou disposição de direitos. (...)".

${ }^{392}$ Sílvio de Salvo Venosa, quando da edição do Código Civil de 2002 já defendia: "No entanto, embora o novo Código Civil não se refira expressamente ao Código de Defesa do Consumidor, não haverá arestas de difícil transposição quanto à aplicação da lei do consumidor perante o novo Código Civil. VENOSA, Silvio de Salvo. O Código do Consumidor e o Código Civil. Publicado em: Valor Econômico, São Paulo, 23 abr. 2002. p. E2. Instituto Brasileiro do Direito do Seguro. Disponível em: <http://www.ibds.com.br/artigos/OCodigodoConsumidoreoCodigoCivil.pdf>. Acesso em: 08 jan. 2014. Ainda, deve-se ter em mente o disposto no art. $7^{\circ}$ do Código de Defesa do Consumidor: "Art. $7^{\circ}$ Os direitos previstos neste código não excluem outros decorrentes de tratados ou convenções internacionais de que o Brasil seja signatário, da legislação interna ordinária, de regulamentos expedidos pelas autoridades administrativas competentes, bem como dos que derivem dos princípios gerais do direito, analogia, costumes e eqüidade.".
} 
Não obstante, a incorporação imobiliária é atividade que tem impacto relevante no mercado de consumo e expõe a sociedade a risco enorme, pelos vultosos valores envolvidos e por se conectar, geralmente, ao direito constitucional de habitação, o que deve ensejar maior cuidado do julgador quando da aplicação das normas aparentemente conflitantes.

Por fim, no tocante ao ônus probatório, vale ressaltar que, de forma contrária ao previsto no art. 333, I, do Código de Processo Civil brasileiro, o Código de Defesa do Consumidor prevê a inversão do ônus da $\operatorname{prova}^{393}$, de forma que caberia ao vendedorfornecedor demonstrar não haver fato constitutivo do direito do adquirente-consumidor.

\subsubsection{Consequências do inadimplemento}

\subsubsection{Especificidades conforme determinadas modalidades}

Verificadas as consequências específicas dos vícios redibitórios, passarão a ser avaliadas as consequências do inadimplemento de obrigações de forma geral, em relação às modalidades de obrigação.

Nas obrigações de dar coisa certa, como mencionado anteriormente, vale a regra que veda a entrega de coisa diversa (aliud pro alio), exposto em nosso ordenamento no art. 313 do Código Civil, prevendo-se o art. 233 do mesmo código que em tal obrigação há abrangência dos acessórios, mesmo que do acordo não conste expressamente ${ }^{394}$.

O devedor, nesse caso, tem obrigação de conservar a coisa com cuidado, zelo e diligência, referindo-se Monteiro a tal obrigação como obrigação de meio, de forma que se verificará a conduta do devedor nesse sentido ${ }^{395}$.

Entretanto, pode haver a perda da coisa, sendo que, sem culpa o devedor, este não responde e a relação obrigacional se extingue, assumindo o próprio devedor o prejuízo da

\footnotetext{
${ }^{393}$ Trata-se de direito básico do consumidor previsto no art. $6^{\circ}$, VIII: “a facilitação da defesa de seus direitos, inclusive com a inversão do ônus da prova, a seu favor, no processo civil, quando, a critério do juiz, for verossímil a alegação ou quando for ele hipossuficiente, segundo as regras ordinárias de experiências.”.

${ }^{394}$ Art. 233. A obrigação de dar coisa certa abrange os acessórios dela embora não mencionados, salvo se o contrário resultar do título ou das circunstâncias do caso.

${ }^{395}$ MONTEIRO DE BARROS, Washington. Curso de direito civil: direito das obrigações: $1^{\text {a }}$ parte: das modalidades, das obrigações, dos efeitos das obrigações, do inadimplemento das obrigações, cit., p. 64.
} 
perda da coisa, em razão da regra "res perit domino". Considerando os arts. 234 a 236 do Código Civil $^{396}$, sendo culpado o devedor, pode o credor exigir o equivalente ou aceitar a coisa no estado em que se acha, neste caso se houver deterioração ${ }^{397}$, sem prejuízo de indenização por perdas e danos.

Deve-se ter em mente que nos contratos onerosos, como o da incorporação, cada parte responde por culpa (o que certamente deve abranger o dolo), ressalvadas exceções legais ${ }^{398}$.

Veja-se, por exemplo, que o art. 400 do Código Civil ${ }^{399}$ prevê que a mora do credor exclui a responsabilidade do devedor pela conservação da coisa, por culpa, além de estabelecer que o credor deverá ressarcir as despesas do devedor na conservação da coisa e pagar-lhe valor excedente, se o valor da coisa oscilar entre o dia estabelecido para o pagamento e o dia efetivo de cumprimento.

No tocante às obrigações de dar coisa incerta, por não interessar diretamente a este trabalho, cabe esclarecer que a coisa incerta deve ser indicada pelo menos pelo gênero e quantidade, ficando a escolha ao devedor, em regra, nunca podendo entregar coisa pior. Cientificado o credor da escolha do devedor, aplica-se, a partir dai, as regras da obrigação de dar coisa certa ${ }^{400}$.

\footnotetext{
${ }^{396}$ Art. 234. Se, no caso do artigo antecedente, a coisa se perder, sem culpa do devedor, antes da tradição, ou pendente a condição suspensiva, fica resolvida a obrigação para ambas as partes; se a perda resultar de culpa do devedor, responderá este pelo equivalente e mais perdas e danos; Art. 236. Sendo culpado o devedor, poderá o credor exigir o equivalente, ou aceitar a coisa no estado em que se acha, com direito a reclamar, em um ou em outro caso, indenização das perdas e danos.

${ }^{397}$ Conforme art. 235, que trata da deterioração: "Art. 235. Deteriorada a coisa, não sendo o devedor culpado, poderá o credor resolver a obrigação, ou aceitar a coisa, abatido de seu preço o valor que perdeu.".

398“Art. 392. Nos contratos benéficos, responde por simples culpa o contratante, a quem o contrato aproveite, e por dolo aquele a quem não favoreça. Nos contratos onerosos, responde cada uma das partes por culpa, salvo as exceções previstas em lei."

${ }^{399}$ Art. 400. A mora do credor subtrai o devedor isento de dolo à responsabilidade pela conservação da coisa, obriga o credor a ressarcir as despesas empregadas em conservá-la, e sujeita-o a recebê-la pela estimação mais favorável ao devedor, se o seu valor oscilar entre o dia estabelecido para o pagamento e o da sua efetivação.

${ }^{400}$ Artigos 243 a 246 do Código Civil, respectivamente: "Art. 243. A coisa incerta será indicada, ao menos, pelo gênero e pela quantidade.

Art. 244. Nas coisas determinadas pelo gênero e pela quantidade, a escolha pertence ao devedor, se o contrário não resultar do título da obrigação; mas não poderá dar a coisa pior, nem será obrigado a prestar a melhor.

Art. 245. Cientificado da escolha o credor, vigorará o disposto na Seção antecedente.

Art. 246. Antes da escolha, não poderá o devedor alegar perda ou deterioração da coisa, ainda que por força maior ou caso fortuito."
} 
Já as obrigações de fazer, indicadas nos artigos 247 a 249 do Código Civil ${ }^{401}$, consistem na atuação do devedor em determinado sentido, não apenas na entrega de determinada coisa, obrigação esta em que o interesse está contido na coisa em si.

Depreende-se de tais artigos que se a prestação for exequível ou imposta apenas ao devedor, sua recusa significará impossibilidade de prestação, não sendo cogitável a coação do devedor que não quer prestar, ainda que a ele caiba a indenização pelos prejuízos causados ao credor.

Havendo impossibilidade sem culpa do devedor, a relação obrigacional extinguese. De outra forma, agindo o devedor com culpa e impossibilitando a prestação, responde por perdas e danos, ressaltando-se que, se para prestar, o devedor tem que colocar sua vida ou saúde em risco, a obrigação será considerada impossível ${ }^{402}$.

Diante da recusa ou da mora do devedor, e sendo possível a prestação e exequível por terceiro, o credor poderá mandar executá-la à custa do devedor, sem prejuízo da indenização por perdas e danos verificados, nos termos do art. 249.

O parágrafo único de citado artigo indica que a execução por terceiro, à custa do devedor, demanda determinação judicial, exceto no caso de medidas urgências, quando o credor pode determinar que terceiro execute a prestação, ainda que não tenha autorização judicial.

Para Monteiro, há casos em que obrigações de dar e de fazer se entrelaçam, cabendo individualizá-las e não unificá-las, de forma que a cada uma incidirão as regras próprias $^{403}$, lição de grande valia no caso da incorporação imobiliária, que, como exposto anteriormente, abrange tanto obrigação de fazer (construção da coisa futura) quanto de dar (entrega da coisa pronta e acabada).

\footnotetext{
${ }^{401}$ Art. 247. Incorre na obrigação de indenizar perdas e danos o devedor que recusar a prestação a ele só imposta, ou só por ele exequiível.

Art. 248. Se a prestação do fato tornar-se impossível sem culpa do devedor, resolver-se-á a obrigação; se por culpa dele, responderá por perdas e danos.

Art. 249. Se o fato puder ser executado por terceiro, será livre ao credor mandá-lo executar à custa do devedor, havendo recusa ou mora deste, sem prejuízo da indenização cabível.

Parágrafo único. Em caso de urgência, pode o credor, independentemente de autorização judicial, executar ou mandar executar o fato, sendo depois ressarcido.

${ }^{402}$ MONTEIRO DE BARROS, Washington. Curso de direito civil: direito das obrigações: $1^{\mathrm{a}}$ parte: das modalidades, das obrigações, dos efeitos das obrigações, do inadimplemento das obrigações, cit., p. 96.

${ }^{403}$ MONTEIRO DE BARROS, Washington. Curso de direito civil: direito das obrigações: $1^{\mathrm{a}}$ parte: das modalidades, das obrigações, dos efeitos das obrigações, do inadimplemento das obrigações, cit., p. 93.
} 
Cabe ressaltar que, tratando-se de obrigação divisível com pluralidade de devedores, a prestação se divide em tantas partes quanto os devedores e, sendo indivisível, todos os devedores respondem pela dívida toda ${ }^{404}$, o que demonstra conexão com a questão da solidariedade, a ser melhor avaliada oportunamente.

\subsubsection{Enjeitamento da prestação e redução da contraprestação}

Já foi objeto de análise a possibilidade de se enjeitar a coisa recebida em contrato comutativo em razão de vícios ocultos, nos termos do art. 441 do Código Civil, bem como sua regulação pelo Código de Defesa do Consumidor, que também permite a rejeição da coisa, verificando-se que nos dois casos há possibilidade, também, de redução da contraprestação.

Há semelhante previsão em relação àquela atinente a vícios redibitórios, no que tange à empreitada, determinando-se que pode o dono da obra rejeitá-la, desde que o empreiteiro tenha se afastado das instruções recebidas, dos planos, projetos ou regras técnicas, podendo o encomendante da obra aceitá-la, com abatimento do preço, como se se tratasse de vício redibitório ${ }^{405}$.

Ao credor, dono da obra, se oferta, conforme artigos 615 e 616, a opção de conservação da relação jurídica com o devedor, se entender que a obra lhe é útil apesar das incongruências, ainda que possa, em razão da manutenção do sinalagma, exigir abatimento de preço, para evitar enriquecimento sem causa do devedor.

Recebida a coisa, entende-se pela presunção de que foi aprovada a conduta do empreiteiro, liberando-se este do dever de execução e da responsabilidade pelos defeitos aparentes $^{406}$, sem prejuízo da responsabilidade pós-entrega da coisa, pela solidez e

\footnotetext{
${ }^{404}$ Nos termos dos artigos 257 e 259 do Código Civil: "Havendo mais de um devedor ou mais de um credor em obrigação divisível, esta presume-se dividida em tantas obrigações, iguais e distintas, quantos os credores ou devedores. " e "Se, havendo dois ou mais devedores, a prestação não for divisível, cada um será obrigado pela dívida toda.".

${ }^{405}$ Nos termos dos arts. 615 e 616: "Concluída a obra de acordo com o ajuste, ou o costume do lugar, o dono é obrigado a recebê-la. Poderá, porém, rejeitá-la, se o empreiteiro se afastou das instruções recebidas e dos planos dados, ou das regras técnicas em trabalhos de tal natureza." e "No caso da segunda parte do artigo antecedente, pode quem encomendou a obra, em vez de enjeitá-la, recebê-la com abatimento no preço.".

${ }^{406}$ Conforme PEREIRA, Caio Mário da Silva. Instituições de direito civil: contratos, cit., v. 3, p. 283.
} 
segurança de edificação, quando se tratar de empreitada de materiais e mão de obra, a ser verificado oportunamente neste trabalho.

Ainda, a lei autoriza o enjeitamento da prestação nos termos do art. 395 do Código Civil em caso de a prestação, devido à mora do devedor, se tornar inútil para o credor.

Repise-se que a mora só enseja o enjeitamento da prestação e consequente extinção da relação contratual se houver inutilidade da prestação para o credor, não sendo admissível que qualquer mora enseje tal possibilidade, devendo haver relevância na mora (ou inadimplemento, no caso) para se consagrar o enjeitamento da prestação.

\subsubsection{Exigência de cumprimento}

Já foi exposto que a distinção entre mora e inadimplemento baseia-se na possibilidade ou não de se cumprir a obrigação ou na existência ou não de interesse útil do credor em relação à prestação.

Dessa forma, sendo possível a prestação ou de interesse do credor, nada obsta que ele exija o cumprimento pelo devedor.

O art. 475 do Código Civil prevê expressamente a exigência do cumprimento, ou melhor, execução específica ${ }^{407}$, se ainda houver utilidade da prestação para o credor, como alternativa, pois, à extinção do vínculo.

Foi mencionado anteriormente que se o devedor tiver que confeccionar a coisa estar-se-á diante de obrigação de fazer, e, se a coisa estiver pronta, de obrigação de dar ${ }^{408}$. Sendo a construção obrigação de fazer, seu descumprimento ensejará a aplicação dos arts. 632 a 638 do Código de Processo Civil ${ }^{409}$.

\footnotetext{
${ }^{407}$ Segundo Sidnei Amendoeira Jr., a execução específica refere-se às hipóteses em que a atuação se dá diretamente sobre o objeto da obrigação. AMENDOEIRA JR., Sidnei. Execução, efetivação e cumprimento. In: BRUSCHI, Gilberto Gomes (Coord.). Execução civil e cumprimento da sentença. São Paulo: Método, 2006. p. 445.

${ }^{408}$ CAMBLER, Everaldo Augusto. Responsabilidade civil na incorporação imobiliária, cit., p. 62.

${ }^{409}$ Art. 632. Quando o objeto da execução for obrigação de fazer, o devedor será citado para satisfazê-la no prazo que o juiz Ihe assinar, se outro não estiver determinado no título executivo. Art. 633. Se, no prazo fixado, o devedor não satisfizer a obrigação, é lícito ao credor, nos próprios autos do processo, requerer que ela seja executada à custa do devedor, ou haver perdas e danos; caso em que ela se converte em indenização.
} 
Nos termos de tais artigos, o devedor é citado pra satisfazer a obrigação no prazo previsto em contrato ou, em sua ausência, no prazo indicado pelo juiz. Deixando de prestar ou prestando de forma incompleta ou defeituosa, o credor pode requerer a execução ou reparação por terceiro, se a obrigação for fungível. Havendo recusa ou mora pelo devedor, abre-se a escolha, ao credor, de executar a obrigação por terceiro ou de converter o descumprimento em indenização. Prestando, contudo, as partes serão ouvidas e, estando de acordo, haverá quitação.

$\mathrm{O}$ art. 461 do Código de Processo Civil define que o juiz, em uma ação de obrigação de fazer, pode conceder tutela específica da obrigação ou determinar providências que assegurem o resultado prático equivalente ao do adimplemento, definindo-se, ainda, que pode haver substituição da prestação por indenização caso o autor opte por isso ou se o adimplemento pela prestação for impossível, sem prejuízo de multa cominatória $^{410}$.

Parágrafo único. O valor das perdas e danos será apurado em liquidação, seguindo-se a execução para cobrança de quantia certa. Art. 634. Se o fato puder ser prestado por terceiro, é lícito ao juiz, a requerimento do exeqüente, decidir que aquele o realize à custa do executado. Parágrafo único. $\mathrm{O}$ exeqüente adiantará as quantias previstas na proposta que, ouvidas as partes, o juiz houver aprovado. Art. 635. Prestado o fato, o juiz ouvirá as partes no prazo de 10 (dez) dias; não havendo impugnação, dará por cumprida a obrigação; em caso contrário, decidirá a impugnação. Art. 636. Se o contratante não prestar o fato no prazo, ou se o praticar de modo incompleto ou defeituoso, poderá o credor requerer ao juiz, no prazo de $10(\mathrm{dez})$ dias, que o autorize a conclú́-lo, ou a repará-lo, por conta do contratante. Parágrafo único. Ouvido o contratante no prazo de 5 (cinco) dias, o juiz mandará avaliar o custo das despesas necessárias e condenará o contratante a pagá-lo.

Art. 637. Se o credor quiser executar, ou mandar executar, sob sua direção e vigilância, as obras e trabalhos necessários à prestação do fato, terá preferência, em igualdade de condições de oferta, ao terceiro. Parágrafo único. O direito de preferência será exercido no prazo de 5 (cinco) dias, contados da apresentação da proposta pelo terceiro (art. 634, parágrafo único). Art. 638. Nas obrigações de fazer, quando for convencionado que o devedor a faça pessoalmente, o credor poderá requerer ao juiz que the assine prazo para cumpri-la. Parágrafo único. Havendo recusa ou mora do devedor, a obrigação pessoal do devedor converter-se-á em perdas e danos, aplicando-se outrossim o disposto no art. 633.

410““Art. 461. Na ação que tenha por objeto o cumprimento de obrigação de fazer ou não fazer, o juiz concederá a tutela específica da obrigação ou, se procedente o pedido, determinará providências que assegurem o resultado prático equivalente ao do adimplemento. § 1o A obrigação somente se converterá em perdas e danos se o autor o requerer ou se impossível a tutela específica ou a obtenção do resultado prático correspondente. § 20 A indenização por perdas e danos dar-se-á sem prejuízo da multa (art. 287). § 3o Sendo relevante o fundamento da demanda e havendo justificado receio de ineficácia do provimento final, é lícito ao juiz conceder a tutela liminarmente ou mediante justificação prévia, citado o réu. A medida liminar poderá ser revogada ou modificada, a qualquer tempo, em decisão fundamentada. § 4o O juiz poderá, na hipótese do parágrafo anterior ou na sentença, impor multa diária ao réu, independentemente de pedido do autor, se for suficiente ou compatível com a obrigação, fixando-lhe prazo razoável para o cumprimento do preceito. § 5o Para a efetivação da tutela específica ou a obtenção do resultado prático equivalente, poderá o juiz, de ofício ou a requerimento, determinar as medidas necessárias, tais como a imposição de multa por tempo de atraso, busca e apreensão, remoção de pessoas e coisas, desfazimento de obras e impedimento de atividade nociva, se necessário com requisição de força policial. § 6o O juiz poderá, de ofício, modificar o valor ou a periodicidade da multa, caso verifique que se tornou insuficiente ou excessiva. 
Trata-se de disposição que dá oportunidade de o credor, em juízo, optar pela conversão de mora, que seria purgável, em inadimplemento, substituindo-se a prestação por indenização.

No tocante a ações relativas à obrigação de entrega de coisa certa, o legislador definiu, nos artigos 621 a $628^{411}$, que o devedor será citado para satisfazer a obrigação em dez dias, ou apresentar embargos, sendo que, neste caso, deve depositar a coisa. Não havendo entrega ou caso os embargos não sejam acolhidos, o juiz pode expedir mandado de imissão na posse, se coisa imóvel, não sendo possível, em nenhuma hipótese, o cumprimento por terceiros. Entregue a coisa no prazo, dá-se por quitada a obrigação.

Ressalte-se que a aplicação desses dispositivos, tanto no que se refere à determinação de entrega, quanto, em caso de descumprimento, à imissão na posse, só é pertinente se a coisa já existir, livre e desembaraçada, o que não ocorre em caso de atraso na entrega do imóvel na incorporação imobiliária, por exemplo.

Às obrigações de dar também devem ser aplicadas as disposições dos parágrafos do art. 461, conforme parágrafo $3^{\circ}$ do art. 461-A do Código de Processo Civil ${ }^{412}$.

\footnotetext{
411“"Art. 621. O devedor de obrigação de entrega de coisa certa, constante de título executivo extrajudicial, será citado para, dentro de 10 (dez) dias, satisfazer a obrigação ou, seguro o juízo (art. 737, II), apresentar embargos. Parágrafo único. O juiz, ao despachar a inicial, poderá fixar multa por dia de atraso no cumprimento da obrigação, ficando o respectivo valor sujeito a alteração, caso se revele insuficiente ou excessivo. Art. 622. O executado poderá depositar a coisa, em vez de entregá-la, quando quiser opor embargos. Art. 623. Depositada a coisa, o exeqüente não poderá levantá-la antes do julgamento dos embargos. Art. 624. Se o executado entregar a coisa, lavrar-se-á o respectivo termo e dar-se-á por finda a execução, salvo se esta, de acordo com a sentença, tiver de prosseguir para o pagamento de frutos e ressarcimento de perdas e danos. Art. 625. Não sendo a coisa entregue ou depositada, nem admitidos embargos suspensivos da execução, expedir-se-á em favor do exeqüente mandado de imissão na posse ou de busca e apreensão, conforme se tratar de imóvel ou de móvel. Art. 626. Alienada a coisa quando já litigiosa, expedir-se-á mandado contra o terceiro adquirente, que somente será ouvido depois de depositá-la. Art. 627. O credor tem direito a receber, além de perdas e danos, o valor da coisa, quando esta não Ihe for entregue, se deteriorou, não for encontrada ou não for reclamada do poder de terceiro adquirente. $\S 1$ o Não constando do título o valor da coisa, ou sendo impossível a sua avaliação, o exeqüente far-lhe-á a estimativa, sujeitando-se ao arbitramento judicial. § 2o Serão apurados em liquidação o valor da coisa e os prejuízos

Art. 628. Havendo benfeitorias indenizáveis feitas na coisa pelo devedor ou por terceiros, de cujo poder ela houver sido tirada, a liquidação prévia é obrigatória. Se houver saldo em favor do devedor, o credor o depositará ao requerer a entrega da coisa; se houver saldo em favor do credor, este poderá cobrá-lo nos autos do mesmo processo."

412،Art. 461-A. Na ação que tenha por objeto a entrega de coisa, o juiz, ao conceder a tutela específica, fixará o prazo para o cumprimento da obrigação. $\S 1$ 1o Tratando-se de entrega de coisa determinada pelo gênero e quantidade, o credor a individualizará na petição inicial, se lhe couber a escolha; cabendo ao devedor escolher, este a entregará individualizada, no prazo fixado pelo juiz. § 2o Não cumprida a obrigação no prazo estabelecido, expedir-se-á em favor do credor mandado de busca e apreensão ou de imissão na posse, conforme se tratar de coisa móvel ou imóvel. § 3o Aplica-se à ação prevista neste artigo o disposto nos $\S \S$ 10 a 60 do art. 461."
} 
$\mathrm{O}$ art. 287 do mesmo código ${ }^{413}$ reitera o direito do autor de ação visando à prestação de ato ou à entrega de coisa requerer cominação de pena pecuniária para o descumprimento da sentença ou da decisão antecipatória de tutela, de forma a tentar coibir que haja novo descumprimento de obrigação.

O Código de Defesa do Consumidor prevê, como visto, a possibilidade de reexecução dos serviços viciados por terceiros, por conta e risco do fornecedor, não definindo a lei se tal providência pode ser realizada independentemente de decisão judicial, devendo-se crer que sim, em razão da finalidade de proteção constante de seu escopo e pelos princípios de facilitação processual previstos no Código em questão.

Não obstante, em relação a questões processuais, tal Código estipula, no art. 84, previsões semelhantes às do art. 461 do Código de Processo Civil, ainda que não haja necessidade, uma vez que as normas do Código de Processo Civil aplicam-se às ações no âmbito do Código de Defesa do Consumidor ${ }^{414}$.

\subsubsection{Resolução do contrato}

A resolução, remédio para dissolução da relação contratual mantida entre as partes, é tratada no art. 475 do Código Civil $^{415}$, que permite que, em caso de inadimplemento, o credor lesado, como alternativa à exigência do cumprimento, pleiteie a resolução do contrato, sem prejuízo da indenização cabível em qualquer dos casos.

Expõe-se que a resolução do contrato é opção do credor, que permite que, em vez de extinguir o vínculo com o devedor, possa mantê-lo, exigindo o cumprimento da obrigação não cumprida $^{416}$.

\footnotetext{
413، Art. 287. Se o autor pedir que seja imposta ao réu a abstenção da prática de algum ato, tolerar alguma atividade, prestar ato ou entregar coisa, poderá requerer cominação de pena pecuniária para o caso de descumprimento da sentença ou da decisão antecipatória de tutela (arts. 461, § 4o, e 461-A)."

414““Art. 90. Aplicam-se às ações previstas neste título as normas do Código de Processo Civil e da Lei $\mathrm{n}^{\circ} 7.347$, de 24 de julho de 1985, inclusive no que respeita ao inquérito civil, naquilo que não contrariar suas disposições."

415“"Art. 475. A parte lesada pelo inadimplemento pode pedir a resolução do contrato, se não preferir exigirlhe o cumprimento, cabendo, em qualquer dos casos, indenização por perdas e danos."

${ }^{416}$ Pedro Romano Martinez, em relação ao direito português, ensina que o credor não tem total liberdade de opção, podendo, contudo, cumular seus direitos, como resolução e indenização. MARTINEZ, Pedro Romano. Cumprimento defeituoso: em especial na compra e venda e na empreitada, cit., p. 126.
} 
Entende-se que a resolução é admitida somente em caso de incumprimento definitivo, qualificado pela perda do interesse do credor ou pela inutilidade da prestação, de forma que a mora só gera a resolução do contrato por expressa disposição legal ou se for convertida em incumprimento definitivo, pela perda do interesse do credor $^{417}$.

Para Pontes de Miranda, "não há confundir-se a responsabilidade no caso do art. 395, parágrafo único, com a responsabilidade em caso de resolução ou resilição", pois aquela refere-se à mora, que não gera, via de regra, a resolução.

Além da hipótese legal de resolução (inadimplemento), as partes podem convencionar que determinados descumprimentos ensejarão o direito à resolução.

Havendo cláusula específica de resolução por inadimplemento ou descumprimento de determinada(s) cláusula(s), tem-se a resolução expressa, que, nos termos do art. 474 do Código Civil $^{418}$, opera-se de pleno direito, sem intervenção judicial ${ }^{419}$.

Ainda que não haja previsão contratual expressa autorizando a resolução do contrato em contrato de incorporação imobiliária, referido contrato, por seu caráter de bilateralidade, contém cláusula comumente denominada resolutiva tácita, dependendo de envolvimento do Judiciário, para que se declare a resolução, conforme parte final do art. 474 citado.

Questão controversa refere-se ao prazo para a ação resolutiva, sendo que Araken de Assis $^{420}$ explana, com razão, que ao crédito líquido constante de instrumento público ou particular aplica-se o prazo de cinco anos, previsto no art. 206, parágrafo $5^{\circ}$, II, do Código Civil $^{421}$, e não o prazo geral de dez anos do art. 205, como determinou o STJ, no REsp 770746\RJ, $3^{\mathrm{a}}$ Turma, julg. em 05.09.06, tendo como relator a Ministra Nancy Andrighi.

\footnotetext{
${ }^{417}$ AGUIAR JÚNIOR, Ruy Rosado de. Extinção dos contratos por incumprimento do devedor: Resolução de acordo com o novo Código Civil, cit., p. 115. No mesmo sentido, Araken de Assis, ao citar que o inadimplemento relativo impede o acesso ao mecanismo resolutório. ASSIS, Araken de. Resolução do contrato por inadimplemento, cit., p. 112.

${ }^{418}$ Art. 474. A cláusula resolutiva expressa opera de pleno direito; a tácita depende de interpelação judicial.

${ }^{419}$ Ressalte-se que nosso ordenamento difere, neste ponto, quanto ao francês, pois neste a resolução é sempre judicial. PEREIRA, Caio Mário da Silva. Instituições de direito civil: contratos, cit., v. 3, p. 133. GOMES, Orlando. Contratos, cit., 26. ed., 2008, p. 207.

${ }^{420}$ ASSIS, Araken de. Resolução do contrato por inadimplemento, cit., p. 151-152.

${ }^{421 ، § 50 ~ E m ~ c i n c o ~ a n o s: ~ I ~-~ a ~ p r e t e n s a ̃ o ~ d e ~ c o b r a n c ̧ a ~ d e ~ d i ́ v i d a s ~ l i ́ q u i d a s ~ c o n s t a n t e s ~ d e ~ i n s t r u m e n t o ~ p u ́ b l i c o ~ o u ~}$ particular;"
} 
Em relação à ação que tenha por finalidade a obtenção de ressarcimento pelos danos causados em caso de resolução, deve-se entender aplicável o prazo específico do art. $206,3^{\circ}, \mathrm{V}^{422}$, de três anos.

\subsubsection{Aplicação de cláusula penal}

A cláusula penal, que deve estar expressamente prevista em contrato ou documento separado, tem tríplice natureza ${ }^{423}$ : reforço da obrigação, pré-avaliação dos $\operatorname{danos}^{424}$ e pena, significando uma punição.

Com razão, trata-se de importante mecanismo para coibir o descumprimento pelo devedor, bem como sanção caso o faça. Ademais, pode significar a prefixação do valor dos danos resultantes da mora ou do inadimplemento.

Segundo o art. 409 do Código Civil ${ }^{425}$, pode-se estipular cláusula penal para a inexecução completa da obrigação, a inexecução de alguma cláusula especial ou para a mora, ensejando, pois, diferentes modalidades.

A cláusula penal compensatória substitui, por alternativa do credor, a obrigação totalmente inadimplida e não pode ser cumulada com a intenção de efetivo cumprimento da obrigação.

A compensatória cumulativa, como cita Limongi França ${ }^{426}$, pode ser exigida com a obrigação, referindo-se, pois, a cláusula especial ou simplesmente mora, sendo, para ele, definida esta no art. 919 do Código Civil de 1916.

Trata-se da cláusula penal moratória, convencionada para o caso de simples atraso ou irregularidade no cumprimento da obrigação principal, podendo ser cumulada com o

\footnotetext{
422،"§ $3^{\mathrm{o}-}$ Em três anos: (...) V - a pretensão de reparação civil;"”

${ }^{423}$ FRANÇA, Rubens Limongi. Teoria e prática da cláusula penal, cit., p. 157.

${ }^{424}$ Para Cavalieri, a cláusula penal "tem por função principal prefixar a indenização no caso de inexecução da obrigação ou de retardamento no seu cumprimento". CAVALIERI FILHO, Sergio. Programa de responsabilidade civil. 4. ed. São Paulo: Malheiros Ed., 2003. p. 285.

425، Art. 409. A cláusula penal estipulada conjuntamente com a obrigação, ou em ato posterior, pode referir-se à inexecução completa da obrigação, à de alguma cláusula especial ou simplesmente à mora.”

${ }^{426}$ FRANÇA, Rubens Limongi. Teoria e prática da cláusula penal, cit., p. 203.
} 
pedido de cumprimento da obrigação, uma vez que não tem finalidade de substituir a obrigação $^{427}$.

A cláusula moratória tem sua aplicação de acordo com os preceitos atinentes à mora, o que significa dizer que, nas obrigações com prazo, tão logo verificado o seu vencimento, aplica-se a multa, e, em caso de obrigações sem prazo, esta é aplicada após constituição em mora ${ }^{428}$.

Entretanto, nada obsta que as partes convencionem que tal pena passará a ser aplicada de outra forma, em outro momento.

Não se pode olvidar que há limitação à estipulação do valor da pena, não podendo este ultrapassar o valor da obrigação principal ${ }^{429}$, sob pena de se caracterizar enriquecimento sem causa do credor, que obteria, assim, benefício superior ao efetivamente contratado.

O art. 413 do Código Civil ${ }^{430}$ prevê a possibilidade de redução, pelo juízo, da cláusula penal, em caso de cumprimento parcial da obrigação, de forma que não se equipare aquele devedor que não adimpliu integralmente a obrigação daquele que adimpliu parte.

Limongi França entende que essa previsão, que no Código Civil anterior correspondia ao art. 924, não é de ordem pública e permite que as partes acordem sua irredutibilidade ${ }^{431}$.

Entretanto, ainda que a cláusula penal seja acordo acessório e decorrente de autonomia da vontade, considerando-se os novos preceitos do atual Código Civil e a redação do artigo que define que o juiz deve atuar dessa forma, interpreta-se que a ele cabe a redução, ainda que acordado de outra forma pelas partes.

\footnotetext{
${ }^{427}$ Conforme previsto no art. 411: "Quando se estipular a cláusula penal para o caso de mora, ou em segurança especial de outra cláusula determinada, terá o credor o arbítrio de exigir a satisfação da pena cominada, juntamente com o desempenho da obrigação principal.".

${ }^{428}$ Como prevê FRANÇA, Rubens Limongi. Teoria e prática da cláusula penal, cit., p. 197. Nesse sentido é a redação do art. 408, que define que: "Incorre de pleno direito o devedor na cláusula penal, desde que, culposamente, deixe de cumprir a obrigação ou se constitua em mora.".

${ }^{429}$ Como previsto no art. 412: "O valor da cominação imposta na cláusula penal não pode exceder o da obrigação principal.".

430، Art. 413. A penalidade deve ser reduzida eqüitativamente pelo juiz se a obrigação principal tiver sido cumprida em parte, ou se o montante da penalidade for manifestamente excessivo, tendo-se em vista a natureza e a finalidade do negócio."

${ }^{431}$ FRANÇA, Rubens Limongi. Teoria e prática da cláusula penal, cit., p. 250.
} 
Não obstante a existência de cláusula penal e seus limites, não se pode afastar a pretensão à indenização por perdas e danos, em casos de responsabilidade configurada.

Ainda que a cláusula penal seja prefixação de danos, o Código Civil de 2002, em seu art. $416^{432}$, trouxe previsão expressa de cobrança de indenização suplementar em relação à cláusula penal especificada em contrato, em caso de o prejuízo ser superior ao valor da pena, desde que as partes tenham expressamente convencionado essa possibilidade e haja comprovação dos danos excedentes ao valor da pena, pois, para se exigir esta, não é necessária comprovação de prejuízo.

Ainda, há entendimento de que pode haver renúncia a eventual cláusula penal estipulada, tendo o credor a opção entre o procedimento ordinário, pleiteando perdas e danos nos termos dos arts. 395 e 402 do Código Civil, o que o sujeita à demora do procedimento judicial e ao ônus de provar o prejuízo, ou, então, pedir diretamente a importância prefixada na cláusula penal ${ }^{433}$.

\subsection{Responsabilidade contratual}

A dicotomia entre responsabilidade contratual e extracontratual, prevista desde épocas mais remotas, define que a responsabilidade, quando advinda de relação anterior entre as partes, é contratual, e quando não decorrer de qualquer vínculo anterior entre as partes envolvidas, é extracontratual ou aquiliana.

\footnotetext{
432،AArt. 416. Para exigir a pena convencional, não é necessário que o credor alegue prejuízo. Parágrafo único. Ainda que o prejuízo exceda ao previsto na cláusula penal, não pode o credor exigir indenização suplementar se assim não foi convencionado. Se o tiver sido, a pena vale como mínimo da indenização, competindo ao credor provar o prejuízo excedente."

${ }^{433}$ Nesse sentido, REsp 734520/MG , Rel. Min. Hélio Quaglia Barbosa, Quarta Turma , julg.em 21/06/2007, do STJ: “(...)7. Num primeiro momento, na falta de critérios mais precisos para se definir quando é compensatória ou moratória a cláusula penal, recomenda a doutrina "que se confronte o seu valor com o da obrigação principal, e, se ressaltar sua patente inferioridade, é moratória" (Caio Mário da Silva Pereira); in casu, como registrado no acórdão guerreado, a cláusula penal foi fixada em $10 \%$ do valor do contrato, o que, à luz do critério acima traçado, exterioriza e denota sua natureza moratória. Ademais, ainda que compensatória fosse a estipulação, "ocorrendo o inadimplemento imputável e culposo, o credor tem a possibilidade de optar entre o procedimento ordinário, pleiteando perdas e danos nos termos dos arts. 395 e 402 (o que o sujeito à demora do procedimento judicial e ao ônus de provar o montante do prejuízo) ou, então, pedir diretamente a importância prefixada na cláusula penal, que corresponde às perdas e danos estipulados a forfait. Daí a utilidade da cláusula penal como instrumento que facilita o recebimento da indenização, poupando ao credor o trabalho de provar, judicialmente, ter havido dano ou prejuízo, livrandose, também, da objeção da falta de interesse patrimonial (Judith Martins-Costa in Comentários ao Novo Código Civil. Do inadimplemento das obrigações. Volume V. Tomo II. Arts. 389 a 420. Coordenador Sálvio de Figueiredo Teixeira. Rio de Janeiro: Forense, 2004, página 490)".
} 
Como regra geral, são elementos indispensáveis para se obter indenização: 1) a ofensa a uma norma preexistente ou erro de conduta, com culpa, podendo ser violação a norma legal ou a dever assumido em contrato; 2) o nexo causal, que é a vinculação entre determinada conduta e o resultado; e 3) o dano, que é a diminuição patrimonial ou a dor, no caso de dano apenas moral ${ }^{434}$.

A culpa, que engloba o dolo e a culpa em sentido estrito, é, no campo da responsabilidade contratual, "inexecução previsível e evitável, por uma parte ou seus sucessores, de obrigação nascida de contrato prejudicial à outra parte ou seus sucessores" ${ }^{435}$.

O ato/fato culposo gera, então, a obrigação de reparar daos causados.

De acordo com o parágrafo único do art. 927 do Código Civil ${ }^{436}$, só haverá obrigação de reparar o dano independentemente de culpa nos casos especificados em lei ou se a atividade desenvolvida pelo autor do dano for considerada de risco, de forma que tal Código tem, como regra primordial, a necessidade de culpa ${ }^{437}$.

O Código de Defesa do Consumidor, entretanto, determina a indenização sem vinculação com a culpa do devedor, em razão dos artigos 12 e 14, que estipulam a responsabilidade objetiva ${ }^{438}$.

Segundo Cavalieri, trata-se da teoria do risco do empreendimento, de forma que o fornecedor age como "garante dos produtos e serviços que oferece no mercado de consumo, respondendo pela qualidade e segurança dos mesmos" (sic) ${ }^{439}$.

\footnotetext{
${ }^{434}$ Conforme STOCO, Rui. Tratado de responsabilidade civil: doutrina e jurisprudência. 9. ed. São Paulo: Ed. Revista dos Tribunais, 2013. p. 192 e ss. No tocante à responsabilidade contratual, tal autor cita que são pressupostos essenciais: existência de contrato válido, inexecução/inadimplemento, nexo causal e mora.

${ }^{435}$ Savatier, R. Traité de la responsabilité civile em droit français, Paris, 1939 apud AGUIAR DIAS, José de. Da responsabilidade civil. 12. ed. Rio de Janeiro: Lumen Juris, 2011. p. 134.

436، Parágrafo único. Haverá obrigação de reparar o dano, independentemente de culpa, nos casos especificados em lei, ou quando a atividade normalmente desenvolvida pelo autor do dano implicar, por sua natureza, risco para os direitos de outrem."

${ }^{437}$ Mas no próprio Código há hipóteses de responsabilidade sem culpa: como a prevista no art. 931, dos empresários individuais e empresas pelos danos causados pelos produtos postos em circulação, a prevista no art. 932, que define que determinadas pessoas respondem por outras, independentemente de sua culpa.

438“"Art. 12 - O fabricante, o produtor, o construtor, nacional ou estrangeiro, e o importador respondem, independentemente da existência de culpa, pela reparação dos danos causados aos consumidores por defeitos decorrentes de projeto, fabricação, construção, montagem, fórmulas manipulação, apresentação ou acondicionamento de seus produtos, bem como por informações insuficientes ou inadequadas sobre sua utilização e riscos." e "Art. 14 - O fornecedor de serviços responde, independentemente da existência de culpa, pela reparação dos danos causados aos consumidores por defeitos relativos à prestação de serviços, bem como por informações insuficientes ou inadequadas sobre sua fruição e riscos. §4 - A responsabilidade pessoal dos profissionais liberais será apurada mediante a verificação de culpa."

${ }^{439}$ CAVALIERI FILHO, Sergio. Programa de direito do consumidor, cit., p. 240.
} 
O nexo causal, como mencionado, é a relação imediata entre a ação ou omissão e o dano causado ${ }^{440}$, havendo hipóteses que quebram aludido nexo, como eventos de caso fortuito e força maior e a causa ocasionada pela vítima ${ }^{441}$.

Quanto aos danos, estes influenciam diretamente o valor da indenização, nos termos do art. 944 do Código Civil $^{442}$, e são caracterizados pela perda no patrimônio material ou imaterial do lesado, abrangendo os danos emergentes, tudo que se perdeu em decorrência do ato/fato, e os lucros cessantes, que incluem o que se deixou de ganhar ${ }^{443}$.

A questão do dano moral é muito debatida, uma vez que a maior parte da doutrina e dos julgadores entende que o descumprimento contratual não enseja danos morais, em razão de o contrato possuir um risco inerente quanto ao descumprimento pela outra parte ${ }^{444}$.

Ressalte-se o Enunciado 159 da III Jornada de Direito Civil do Conselho da Justiça Federal: “Art. 186: O dano moral, assim compreendido todo dano extrapatrimonial, não se caracteriza quando há mero aborrecimento inerente a prejuízo material.”.

Não obstante, diante das circunstâncias de determinado caso, é possível, sim, que o descumprimento contratual gere abalo moral. Contudo, tal definição dependerá do julgador e seu entendimento quanto a tais circunstâncias, como se depreende de determinados julgados que levaram em consideração aspectos subjetivos e circunstanciais para estabelecer a existência do dever de indenizar por danos morais acarretados por descumprimento contratual ${ }^{445}$.

${ }^{440} \mathrm{O}$ artigo 403 do Código Civil estabelece que as perdas e danos incluem os prejuízos efetivos e os lucros cessantes por efeito direto e imediato da inexecução.

${ }^{441}$ AMARAL, Francisco. Os atos ilícitos. In: MENDES, Gilmar Ferreira; FRANCIULLI NETO, Domingos (Coords.). O novo Código Civil: estudos em homenagem ao Prof. Miguel Reale. São Paulo: LTr, 2003. p. 158.

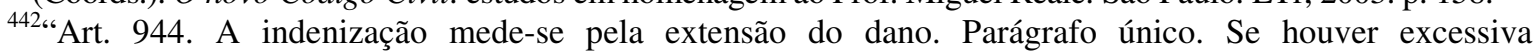
desproporção entre a gravidade da culpa e o dano, poderá o juiz reduzir, eqüitativamente, a indenização."

443“"Art. 402. Salvo as exceções expressamente previstas em lei, as perdas e danos devidas ao credor abrangem, além do que ele efetivamente perdeu, o que razoavelmente deixou de lucrar."

${ }^{444}$ Veja-se julgamento de REsp $\mathrm{n}^{\circ} 1.352 .962$ - PB, Rel. Min.Sidnei Beneti, Terceira Turma, STJ, em 07/05/2013, que excluiu da condenação danos morais estabelecidos em instância inferior: "RECURSO ESPECIAL - AÇÃO DE RESPONSABILIDADE CIVIL - AQUISIÇÃO DE UNIDADE IMOBILIÁRIA EM CONSTRUÇÃO - ENTREGA DO IMÓVEL COM ATRASO -DEFEITOS NA CONSTRUÇÃO DESCUMPRIMENTO DO CONTRATO PELO CONSTRUTOR - DANO MATERIAIS E MORAIS COMPENSAÇÃO COM ANTECIPAÇÃO DA QUITAÇÃO DO DÉBITO TOTAL DO IMÓVEL DECISÃO ULTRA PETITA - OCORRÊNCIA - RECURSO ESPECIAL PARCIALMENTE PROVIDO. (...) 3.- Recurso Especial provido em parte para decote de condenação a fato não constante do pedido, bem como para decotar assim a condenação por danos morais.”.

${ }^{445}$ Veja que o próprio STJ defende a casuística para verificação de danos morais por descumprimento contratual: "O reconhecimento, pelas instâncias ordinárias, de circunstâncias que excedem o mero descumprimento contratual torna devida a reparação moral. (REsp 714.947/RS, Rel. Min.Cesar Asfor Rocha, Quarta Turma, julg. em 28/03/2006). Como explicitado também na Apelação no 002463552.2011.8.26.0554, $4^{\mathrm{a}}$ Câmara de Direito Privado do Tribunal de Justiça de São Paulo, Rel. Des. Carlos 
Entende-se, com razão, que pode haver pretensões diversas, como aquelas previstas para as ações edilícias, como a indenizatória ${ }^{446}$.

No tocante ao Código Civil, Pontes de Miranda entende que é perfeitamente cabível, pois as ações edilícias e a ação de indenização teriam objetos diferentes, visando soluções diferentes ${ }^{447}$.

Não se pode afastar a pretensão à indenização, sempre que se estiver diante de fato que configure a responsabilidade, ou seja, diante de ato ou fato imputável, nexo causal entre ato do ofensor e prejuízo causado.

Ademais, deve-se reforçar que a indenização é prevista, de forma geral, em casos em que há não cumprimento da obrigação; mora convertida em inadimplemento; ou na hipótese de inadimplemento que gere a possibilidade de resolução contratual ou opção de arguir pelo cumprimento da obrigação, nos termos, respectivamente, dos arts. 389, 395 e 475 do Código Civil.

Aplica-se o prazo prescricional de três anos, como previsto no art. 206, parágrafo $3^{\circ}, \mathrm{V}$, do Código Civil, para ações em que se pretenda a reparação de danos ${ }^{448}$.

Cavalieri, referindo-se ao disposto no Código de Defesa do Consumidor, defende não ser possível a pretensão indenizatória especificamente decorrente de vícios, com suporte na distinção entre dano circa rem e dano extra rem. Para ele, "o dano circa rem, por ser imanente ao vício do produto ou do serviço, não gera pretensão autônoma”, mas "o

Henrique Miguel Trevisan, em 12 de dezembro de 2013: “(...) Quanto à indenização por danos morais, este Egrégio Tribunal de Justiça tem entendimento predominante no sentido de que, salvo circunstância excepcional que coloque o contratante em situação de extraordinária angústia ou humilhação, no caso inexistente, não há dano moral a ser reparado. É que o dissabor inerente à expectativa frustrada decorrente de inadimplemento contratual se insere no cotidiano do homem médio e, a princípio, não resulta em lesão à honra ou em violação à dignidade humana, conforme precedentes deste Egrégio Tribunal de Justiça(...)”.

${ }^{446}$ Nesse sentido, REsp 734520/MG, da Quarta Turma do STJ, já mencionado neste trabalho: “(...) 5. Quanto à alegada decadência do direito à redibição, afastou-a peremptoriamente o Tribunal das Alterosas, porque cuidava, na espécie, de pedido de indenização por danos sofridos e não, de resolução contratual por vício no objeto da prestação. E, mais antigo, julgamento do RExt 56182-SP, pelo STF, Terceira Turma, em 11.11.66, no sentido de que a ação era de indenização e não de redibição do contrato.

${ }^{447}$ PONTES DE MIRANDA, Francisco Cavalcanti. Tratado de direito privado: parte especial, cit., t. 38 , p. 301. Em sentido contrário, Scartezzini, que entende que no caso dos vícios redibitórios, a indenização, pelo Código Civil, depende de dolo do alienante, por haver previsão expressa nesse sentido apenas no art. 443. GUIMARÃES, Paulo Jorge Scartezzini. Vícios do produto e do serviço por qualidade, quantidade e insegurança: cumprimento imperfeito do contrato, cit., p. 274.

${ }^{448}$ Para ações de inadimplemento contratual, o STJ decidiu, anteriormente ao Código Civil de 2002, que o prazo era de 20 anos, no REsp. n 32676, Rel. Min. Fontes de Alencar, $4^{\circ}$ Turma, julg. Em 09.08.93. 
dano extra rem, cujo fato gerador é a conduta do fornecedor posterior ao vício", enseja a pretensão indenizatória autônoma ${ }^{449}$.

Carece razão ao autor, uma vez que os artigos que se referem à possibilidade de redibição do contrato, em casos de vícios de produtos/serviços, mencionam também o direito de reparação por perdas e danos causados pela redibição ${ }^{450}$, ainda que esses danos possam ser resultantes unicamente da redibição, e não por danos extrínsecos.

Admite-se a indenização nessa hipótese também, não devendo, contudo, haver aplicação dos prazos específicos, decadenciais, por ser inconveniente haver limitação de prazo para ações cuja pretensão é completamente diversa aos exíguos prazos previstos para outra hipótese.

Ressalte-se que o art. 27 do Código de Defesa do Consumidor prevê prazo prescricional de cinco anos apenas para casos de reparação de danos causados por fato do produto ou do serviço, excluindo-se sua aplicação a casos decorrentes de vícios, uma vez que, para esses, há os prazos específicos para os remédios correspondentes.

Em relação à incompatibilização dos prazos prescricionais para reparação de danos previstos no Código Civil e no Código de Defesa do Consumidor, novamente cabe ressaltar que o Código Civil possui prazo superior, sendo mais benéfico ao consumidor, o que demonstra a pertinência de se alegar a aplicação do prazo de cinco anos do código consumerista e não o de três anos previsto no art. 206, parágrafo $3^{\circ}, \mathrm{V}$, Código Civil.

\subsubsection{Exclusão e limitação}

Com base no Código Civil, podemos definir as seguintes hipóteses de exclusão de responsabilidade: caso fortuito ou força maior pelo qual o devedor não tenha expressamente se obrigado ${ }^{451}$, culpa exclusiva da vítima ou de terceiros.

\footnotetext{
${ }^{449}$ CAVALIERI FILHO, Sergio. Programa de direito do consumidor, cit., p. 269-270.

${ }^{450}$ Quanto a essa reparação, Denari, Zelmo, explana que "Esse ressarcimento é inconfundível, ontologicamente, como aqueloutro previsto no art. 12", derivando, no caso do art. 18, "direta e indiretamente da inexecução contratual". GRINOVER, Ada Pellegrini et al. Código Brasileiro de Defesa do Consumidor: comentado pelos autores do anteprojeto, cit., 7.ed, p. 187.

${ }^{451}$ Exceto se houver impossibilidade decorrente de caso fortuito ou força maior, mas durante a mora do devedor, tendo este agido com culpa, nos termos do art. 399 do Código Civil: "O devedor em mora responde pela impossibilidade da prestação, embora essa impossibilidade resulte de caso fortuito ou de força maior, se estes ocorrerem durante o atraso; salvo se provar isenção de culpa, ou que o dano sobreviria ainda quando a obrigação fosse oportunamente desempenhada.".
} 
A culpa concorrente enseja não a exclusão, mas a limitação da responsabilidade, pois cada parte arcaria em determinada proporção com os prejuízos causados.

Ressalte-se que o Código de Defesa do Consumidor veda, em seu art. 24 e 25, a exclusão ou limitação de responsabilidade, a critério do fabricante/comerciante, com exceção de relação de consumo entre fornecedor e consumidor pessoa jurídica, em que poderá haver limitação em situações justificáveis, conforme parte final do art 51, I.

O Código de Defesa do Consumidor segue as regras básicas de responsabilidade civil, no que se refere a culpa de terceiros e da própria vítima.

A culpa exclusiva de terceiros, prevista tanto no art. $12^{452}$, quanto no art. $14^{453}$, refere-se, obviamente, a terceiro que não participe da cadeia de fornecimento, uma vez que, sendo parte definida por lei como solidariamente responsável, não é terceiro.

No tocante à culpa exclusiva do consumidor, prevista nos arts. 12, III e 14, II, a conduta do consumidor deve ser causa direta e determinante do evento e, de acordo com a literalidade da norma, exclusiva. Havendo culpa concorrente do consumidor, não se pode afirmar que haverá exclusão de responsabilidade.

Veja-se, ainda, que não há previsão semelhante quanto aos vícios de produtos, pois estes, entende-se, são intrinsicamente relacionados à coisa em si.

Ainda, o Código de Defesa do Consumidor prevê, desnecessariamente, que não será responsável o fornecedor que provar que não colocou o produto no mercado ou que o produto ou serviço não é defeituoso, de acordo com os incisos I e II do art. 12 e o art. 14, parágrafo $3^{\circ}$, I, uma vez que nessas hipóteses, evidentemente, não haverá nexo causal, pois ausente conduta reprovável do fornecedor.

Lembremos que o nexo causal deve estar presente, independentemente da caracterização de responsabilidade objetiva, que independe de outro elemento, qual seja, a culpa.

Afirmação esta que é válida em relação às obrigações de resultado, que, ainda que não ensejem, inicialmente, a verificação de atitude culposa do devedor ${ }^{454}$, não podem ser

\footnotetext{
${ }^{452}$ Art. 12 , $\S 3^{\circ}$, III: “...O fabricante, o construtor, o produtor ou importador só não será responsabilizado quando provar: (...) III - a culpa exclusiva do consumidor ou de terceiro.”.

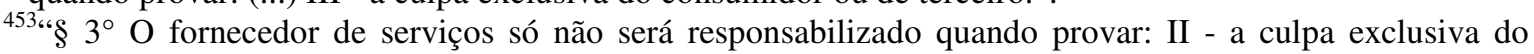
consumidor ou de terceiro."

${ }^{454}$ Rui Stoco afirma que a teoria da culpa não foi dissolvida na obrigação de resultado, cabendo, na obrigação de meio, que o credor prove a culpa, e na de resultado, que o devedor prove que não agiu inadequada ou culposamente. STOCO, Rui. Tratado de responsabilidade civil: doutrina e jurisprudência, cit., 9. ed. p. 230.
} 
propulsoras de responsabilidade em hipóteses que dissolvam o nexo causal, de forma que só haverá responsabilidade se os demais elementos desta estiverem caracterizados.

No que se refere a caso fortuito e força maior, o Código de Defesa do Consumidor não inseriu tais hipóteses como excludentes de responsabilidade, havendo entendimento de que, assim, não caberiam em casos de relação de consumo ${ }^{455}$.

Contudo, sendo tal excludente regra tradicional do direito brasileiro, não se pode afastar sua aplicação a qualquer norma de relação civil, mesmo que de consumo ${ }^{456}$.

São casos de exclusão legal de responsabilidade, previstas pelo legislador, de forma que este proíbe, no âmbito das relações consumeristas, a determinação de outras causas de exclusão e de limitação de responsabilidade ${ }^{457}$, de forma a evitar que o consumidor seja prejudicado pela preponderância contratual do fornecedor.

Assim, no tocante a cláusulas que indiquem qualquer forma de limitação de responsabilidade, inclusive as que impõem procedimento a ser seguido para exercício de direito ou pretenda estabelecer a ruptura de nexo causal em virtude de qualquer acontecimento, temos sua completa ineficácia, com base no Código de Defesa do Consumidor.

Tratando-se de contratos no âmbito das relações comuns civis, é comum que haja estipulação de outras exclusões, como por danos indiretos e lucros cessantes. Ainda, limita-se a determinado valor as indenizações decorrentes de responsabilidade emanada de contratos.

Cavalieri cita, com razão, que cláusulas que excluem responsabilidade devem ser chamadas de "cláusula de não indenizar", uma vez que a obrigação e a responsabilidade não deixam de existir, afastando-se, somente, a indenização ${ }^{458}$.

Tal limitação é aceita, de forma geral, devendo haver, contudo, delimitação de cláusulas dessa espécie, ressaltando-se que a autonomia da vontade encontra limite na ordem pública e na boa-fé objetiva ${ }^{459}$.

\footnotetext{
${ }^{455}$ RIZZATO NUNES, Luiz Antonio. Comentários ao Código de Defesa do Consumidor, cit., p. 220.

${ }^{456}$ Esse é o entendimento também de Cavalieri, que informa a distinção entre fortuito interno e fortuito externo, sendo este fato que não guarda relação com a atividade do fornecedor, eximindo, pois o fornecedor de responsabilidade, e aquele fato imprevisível, porém ocorrido no momento da fabricação do produto ou da prestação do serviço, ligando-se aos riscos do negócio, de forma que não isenta o fornecedor de responsabilidade. (CAVALIERI FILHO, Sergio. Programa de direito do consumidor, cit., p. 256).

${ }^{457}$ Como já visto no art. 25 de tal Código.

${ }^{458}$ CAVALIERI FILHO, Sergio. Programa de direito do consumidor, cit., p. 502-503.

${ }^{459}$ Nesse sentido, veja-se entendimento que afasta cláusulas desse tipo em caso de culpa grave: AgRg no AREsp 186192/SP, STJ, Terceira Turma,Min. Ricardo Villas Bôas Cueva, julg. em 21.03.13: "AGRAVO
} 


\subsubsection{Solidariedade}

Não obstante o instituto da solidariedade não estar restrito ao conceito da responsabilidade contratual, sendo tratado, inclusive, no TÍTULO I - DAS MODALIDADES DAS OBRIGAÇÕES do LIVRO I - DO DIREITO DAS OBRIGAÇÕES do Código Civil, para simplificação lógica do presente, avaliaremos-o neste item.

É pertinente identificar as situações em que se autoriza a solidariedade entre partes, bem como as consequências de tal solidariedade.

A solidariedade, que se caracteriza tanto pela pluralidade de credores quanto de devedores ${ }^{460}$, acaba por se diferenciar no tocante à sua consequência em caso de obrigação divisível ou indivisível, como já visto, sendo que naquela a obrigação se divide em partes de acordo com o número de devedores e nesta o devedor solidário é obrigado pela prestação integral.

$\mathrm{O}$ art. 275 do Código Civil ${ }^{461}$ prevê, no que tange à solidariedade passiva, que o credor pode exigir de um ou alguns dos devedores, a seu critério, a dívida comum a todos, sendo que se receber de forma parcial, os demais devedores continuam obrigados pelo restante.

Depreende-se do parágrafo único do artigo citado que o credor pode propor ação contra um ou alguns devedores, sem que isso represente renúncia à solidariedade. Não obstante, há previsão de que o credor pode renunciar conscientemente à solidariedade de algum ou alguns devedores, hipótese em que subsistirá a solidariedade daqueles que não foram exonerados ${ }^{462}$, e, de forma nenhuma, afetará o crédito em si.

REGIMENTAL NO AGRAVO EM RECURSO ESPECIAL. TRANSPORTE AÉREO. CARGA EXTRAVIADA. ACÓRDÃO RECORRIDO: CULPA GRAVE DA TRANSPORTADORA. INDENIZAÇÃO PLENA. LIMITAÇÃO DA RESPONSABILIDADE. REEXAME DE PROVAS.”

${ }^{460}$ Não obstante, neste item será analisada a solidariedade passiva, ou seja, no tocante aos devedores.

461،Art. 275. O credor tem direito a exigir e receber de um ou de alguns dos devedores, parcial ou totalmente, a dívida comum; se o pagamento tiver sido parcial, todos os demais devedores continuam obrigados solidariamente pelo resto.

Parágrafo único. Não importará renúncia da solidariedade a propositura de ação pelo credor contra um ou alguns dos devedores."

${ }^{462}$ Conforme art. 282: "O credor pode renunciar à solidariedade em favor de um, de alguns ou de todos os devedores. Parágrafo único. Se o credor exonerar da solidariedade um ou mais devedores, subsistirá a dos demais.". 
Entende-se que aquele que for demandado pode arguir exceções pessoais ou as que sejam comuns a todos os deveres, não podendo se beneficiar de exceção pessoal de outro codevedor ${ }^{463}$.

Importante definição é a de que o devedor que pagar a dívida integralmente pode exigir dos demais devedores o pagamento de sua respectiva quota, sendo que a lei define presunção de igualdade na divisão do débito ${ }^{464}$.

Assim, ainda que o credor possa acionar qualquer um dos devedores, sem benefício de ordem ${ }^{465}$, aquele que pagar ao credor pode se valer do direito de regresso contra os demais, de forma que haja recomposição de seu patrimônio, uma vez que sua obrigação inicial não é correspondente ao todo da dívida, mas tão somente a parte dela.

Cabe ressaltar que, de acordo com o art. 263, a indivisibilidade está na prestação, não se aplicando, pois, em caso de conversão da obrigação em perdas e danos. Ainda, nos termos do art. $414^{466}$, não se aplica a regra da indivisibilidade para a cláusula penal eventualmente estipulada em contrato ${ }^{467}$, já que cada um responde por sua quota.

Outra característica essencial está contida no art. 279 do Código Civil ${ }^{468}$, que se refere à impossibilidade da prestação: se por culpa de um dos devedores solidários, a todos cabe o pagamento do equivalente, mas apenas o devedor solidário que agiu com culpa será responsabilizado pelas perdas e danos.

Depreende-se que a solidariedade é benéfica ao credor, por assegurar um maior número de patrimônio a responder pela dívida, o que se mostra como maior benefício em

\footnotetext{
${ }^{463}$ Como previsto no art. 281 do Código Civil: "O devedor demandado pode opor ao credor as exceções que lhe forem pessoais e as comuns a todos; não lhe aproveitando as exceções pessoais a outro co-devedor.”.

${ }^{464}$ Conforme art. 283 do Código Civil, que assim dispõe: "O devedor que satisfez a dívida por inteiro tem direito a exigir de cada um dos co-devedores a sua quota, dividindo-se igualmente por todos a do insolvente, se o houver, presumindo-se iguais, no débito, as partes de todos os co-devedores.".

${ }^{465}$ Nesse sentido, não há litisconsórcio necessário, pois se trata de escolha do credor demandar contra determinado(s) devedor(es).

466، Art. 414. Sendo indivisível a obrigação, todos os devedores, caindo em falta um deles, incorrerão na pena; mas esta só se poderá demandar integralmente do culpado, respondendo cada um dos outros somente pela sua quota."

${ }^{467}$ DUARTE, Nestor. Obrigações alternativas, divisíveis e indivisíveis. In: MENDES, Gilmar Ferreira; FRANCIULli NETO, Domingos (Coords.). O novo Código Civil: estudos em homenagem ao Prof. Ives Gandra Martins Filho. São Paulo: LTr, 2003. p. 236.

${ }^{468}$ Cuja redação é a seguinte: "Impossibilitando-se a prestação por culpa de um dos devedores solidários, subsiste para todos o encargo de pagar o equivalente; mas pelas perdas e danos só responde o culpado.".
} 
caso de insolvência de um dos devedores solidários. Ainda, como expõe José Maria da Costa, o credor pode comparecer nas falências dos devedores com o crédito integral ${ }^{469}$.

A solidariedade em nosso ordenamento, ao contrário do ordenamento italiano ${ }^{470}$, não se presume, requerendo, pois, disposição legal ou acordo entre as partes, nos termos do art. 265 do Código Civil ${ }^{471}$.

A Lei de Incorporação Imobiliária, em seu art. 31, parágrafo terceiro ${ }^{472}$, define a solidariedade entre os agentes da incorporação imobiliária.

Outros artigos indicam também a solidariedade, como o 35 , parágrafo $3^{\circ}$, que impõe a solidariedade na devolução de valores pagos pelos adquirentes, pelo proprietário do terreno ou de direitos sobre este, quando tal pessoa denuncia a incorporação no prazo de cinco dias do término do prazo de carência; além do art. 44, parágrafo $1^{\circ}$, que impõe a solidariedade como pena ao construtor que, após concessão do habite-se, não requerer averbação da construção em caso de omissão do incorporador; e o art. $66^{473}$, definindo a solidariedade entre corretor, proprietário e construtor, caso o incorporador não figure no contrato incorporativo, ainda que se trate da responsabilidade penal.

Segundo Cambler, no caso de construção por empreitada, independentemente de ser ou não o construtor, responde o incorporador pela obra, uma vez que este se obriga a realizar a construção, ainda que por terceiro por ele contratado. Dessa forma, há definição de solidariedade entre incorporador e construtor, pois, de acordo com Cambler, em razão da substituição havida mediante contratação de construtor pelo incorporador, "quem se faz substituir é responsável, juntamente com o substituto"

Da mesma forma, Cavalieri explana que o incorporador é chave do empreendimento, não sendo apenas aquele que vende frações ideais do terreno, mas

\footnotetext{
${ }^{469}$ COSTA, José Maria da. As obrigações solidárias. In: MENDES, Gilmar Ferreira; FRANCIULLI NETO, Domingos (Coords.). O novo Código Civil: estudos em homenagem ao Prof. Ives Gandra Martins Filho. São Paulo: LTr, 2003. p. 277.

${ }^{470}$ O Código Civil italiano, em seu artigo 1.294, prevê a presunção de solidariedade entre devedores se a lei ou o título não dispor de forma contrária: "inserir artigo".

471" Art. 265. A solidariedade não se presume; resulta da lei ou da vontade das partes."

472،"§ $3^{\circ}$ Tôda e qualquer incorporação, independentemente da forma por que seja constituída, terá um ou mais incorporadores solidàriamente responsáveis, ainda que em fase subordinada a período de carência, referido no art. 34."

473“Parágrafo único. No caso de contratos relativos a incorporações, de que não participe o incorporador, responderão solidàriamente pelas faltas capituladas neste artigo o construtor, o corretor, o proprietário ou titular de direitos aquisitivos do terreno, desde que figurem no contrato, com direito regressivo sôbre o incorporador, se as faltas cometidas lhe forem imputáveis."

${ }^{474}$ CAMBLER, Everaldo Augusto. Responsabilidade civil na incorporação imobiliária, cit., p. 220.
} 
também o construtor e o proprietário do terreno, todos respondendo, assim, solidariamente pela inexecução, em razão do disposto no parágrafo $3^{\circ}$ do art. 31 da Lei $n^{\circ} 4.591 / 64^{475}$.

Igualmente, Caio Mario entende que o incorporador age "in nomine suo e por direito próprio", devendo suportar os riscos da atividade. Se mais de um, todos devem ser solidariamente responsáveis ${ }^{476}$.

Ainda que não se refira expressamente à solidariedade, o art. 40 define atribuição ao proprietário do terreno em que se erguerá edificação, caso haja "rescisão de contrato de alienação do terreno ou de fração ideal" e consequente consolidação, em seu favor, do direito sobre eventual construção existente, cabendo a ele indenizar diretamente os adquirentes pela parte construída quando da rescisão ${ }^{477}$.

Cabe trazer à baila o regramento atinente à solidariedade estipulado no Código de Defesa do Consumidor: segundo o disposto no art. 25 , parágrafo $1^{\circ}$, de referido Código ${ }^{478}$, definiu-se a solidariedade entre todos causadores de danos a consumidores; conforme parágrafo único do art. $7^{\circ}$, se uma ofensa tiver mais de um autor, todos responderão solidariamente pela reparação dos danos ${ }^{479}$; e, de acordo com o art. $18^{480}$, os fornecedores de produtos respondem solidariamente pelos vícios de qualidade ou quantidade.

\footnotetext{
${ }^{475}$ CAVALIERI FILHO, Sergio. Programa de direito do consumidor, cit., p. 229.

${ }^{476}$ PEREIRA, Caio Mário da Silva. Condomínio e incorporações, cit., p. 245.

${ }^{477} \mathrm{O}$ art. 40 da Lei trata da extinção do contrato de alienação do terreno ou fração ideal, ficando o alienante em cujo favor se opera a resolução, responsável pelo pagamento, ao adquirente, do valor da parcela de construção que haja sido adicionado à unidade, uma vez que haverá consolidação do direito sobre a construção existente. Em relação ao assunto, entendimento de que o proprietário, ainda que não tenha agido como incorporador, deve indenizar os adquirentes em razão da consolidação da propriedade, é esposado, exemplificativamente, no AgRg 2008/0267297-9 nos EDcl no REsp 1107117/SC, Rel. Ministro VASCO DELLA GIUSTINA, Terceira Turma do STJ, julg. em 22/02/2011, e o REsp 879548 / SP, Rel. Min. SIDNEI BENETI, Terceira Turma do STJ, julg. em 17/08/2010, cuja ementa é a seguinte: "DIREITO CIVIL. CONTRATO. PERMUTA. DESCUMPRIMENTO DE CLÁUSULA CONTRATUAL. OBRA NÃO CONCLUÍDA. VENDA DAS UNIDADES A TERCEIROS DE BOA-FÉ. RESCISÃO DO CONTRATO. REINTEGRAÇÃO NA POSSE. DEFERIMENTO. ART. 40, § $2^{\circ}$, LEI N. 4.591/64. RECURSO PROVIDO.I Em contrato de permuta, no qual uma das partes entra com o imóvel e outra com a construção, não tendo os proprietários do terreno exercido atos de incorporação - uma vez que não tomaram a iniciativa nem assumiram a responsabilidade da incorporação, não havendo contratado a construção do edifício - não cumprida pela construtora sua parte, deve ser deferida aos proprietários do imóvel a reintegração na posse. II - O deferimento, no entanto, fica condicionado às exigências do $\S 2^{\circ}$ do art. 40 da Lei das Incorporações, Lei $n^{\circ}$ 4.591/64, para inclusive resguardar os interesses de eventuais terceiros interessados.".

478، Art. 25. (...). § $1^{\circ}$ Havendo mais de um responsável pela causação do dano, todos responderão solidariamente pela reparação prevista nesta e nas seções anteriores."

${ }^{479}$ “Art. $7^{\circ}$ (...). Parágrafo único. Tendo mais de um autor a ofensa, todos responderão solidariamente pela reparação dos danos previstos nas normas de consumo."

480“Art. 18. Os fornecedores de produtos de consumo duráveis ou não duráveis respondem solidariamente pelos vícios de qualidade ou quantidade que os tornem impróprios ou inadequados ao consumo a que se destinam ou lhes diminuam o valor, assim como por aqueles decorrentes da disparidade, com a indicações constantes do recipiente, da embalagem, rotulagem ou mensagem publicitária, respeitadas as variações decorrentes de sua natureza, podendo o consumidor exigir a substituição das partes viciadas.” (sic)
} 
Ressalte-se que, sendo o incorporador propulsor do empreendimento, deve responder pelos atos de terceiros que envolver para cumprimento da obrigação e, havendo culpa de terceiro aposto pelo obrigado principal, não se cogita se o responsável agiu ou não com culpa na escolha ${ }^{481}$, o que significa dizer que não é necessária a constatação de culpa in elegendo pelo obrigado principal para que este seja de fato responsabilizado pelo descumprimento de obrigação ${ }^{482}$.

O Código Civil traz, também, previsões de solidariedade, como a contida no art. $942^{483}$, de forma que todos os que violarem o direito de terceiro responderão solidariamente.

Assim, em razão de conceitos gerais atinentes às obrigações e por haver previsão expressa de solidariedade na lei específica da incorporação imobiliária, sem prejuízo da estipulação no mesmo sentido contida no Código de Defesa do Consumidor, tem-se clara a solidariedade dos agentes atuantes no empreendimento.

${ }^{481}$ AGUIAR JÚNIOR, Ruy Rosado de. Extinção dos contratos por incumprimento do devedor: Resolução de acordo com o novo Código Civil, cit., p. 111.

482،" De conformidade com o disposto no art. 1.521, III, do CC, responde o preponente pela reparação dos danos causados por seu preposto no exercício do trabalho ou por ocasião dele.". Conforme GUALHANONE, Álvaro Luiz Damásio. O incorporador como empresa. Revista de Direito Imobiliário, São Paulo, v. 7, p. 33, jan. 1981.

483، Art. 942. Os bens do responsável pela ofensa ou violação do direito de outrem ficam sujeitos à reparação do dano causado; e, se a ofensa tiver mais de um autor, todos responderão solidariamente pela reparação. Parágrafo único. São solidariamente responsáveis com os autores os co-autores e as pessoas designadas no art. 932." 


\section{RESPONSABILIDADE PELA ENTREgA E PELOS VÍCIOS DA COISA NA INCORPORAÇÃO IMOBILIÁRIA}

Verificadas as obrigações do incorporador, conceitos básicos atinentes às obrigações e responsabilidade consequente, inclusive, solidariedade, cabe-nos avaliar, faticamente, a responsabilidade pela entrega da coisa e seus vícios, na incorporação imobiliária.

Ressalte-se que uma das formas mais básicas de extinção de contrato é a execução voluntária das obrigações das partes, o que, no caso da incorporação imobiliária, ocorre por meio da conclusão da edificação e de sua regularização mediante obtenção de habite-se e averbação da construção, com a posterior entrega da unidade autônoma individualizada e de acordo com o projeto de construção e efetivação da transferência da propriedade de tal unidade.

Contudo, o risco surge quando essas obrigações não são adequadamente cumpridas, como passaremos a expor.

Este capítulo 5 será segregado em dois principais aspectos: o não econômico, que envolve hipóteses que não se referem à capacidade financeira de solvência do incorporador; e o econômico, que inclui hipóteses de insolvêncialfalência do incorporador e do inadimplemento relativo ao financiamento de obra obtido pelo incorporador.

\subsection{Aspectos não ecônomicos}

Impõe-se, diante da segregação mencionada, a análise de determinadas hipóteses de responsabilidade do incorporador, não ligadas a aspectos econômicos, abrangendo o atraso na entrega do imóvel e hipóteses de vícios ou mau cumprimento.

\subsubsection{Atraso na entrega do imóvel}

É certo que o incorporador não pode ter obrigação de entrega da coisa sem termo final definido, devendo evitar qualquer desvio no cronograma das obras. 
A Lei $\mathrm{n}^{\mathrm{o}} 4.591 / 64$, ao definir o incorporador em seu art. 29, menciona a responsabilidade, conforme o caso, pela entrega, a certo prazo, preço e determinadas condições, das obras concluídas, sendo, pois, aplicável a qualquer modalidade de incorporação.

Afirma-se, assim, que o incorporador deve observar o conteúdo legal e o contratual, a fim de entregar o imóvel devidamente acabado e no prazo contratado.

Para tanto, ao incorporador cabe dar andamento regular às obras, como exposto no art. 43, VI, da Lei de Incorporação Imobiliária ${ }^{484}$, aplicando-se tal disposição também ao construtor que contratar, por empreitada a preço fixo, a obra em incorporação, conforme art. $57 \mathrm{da} \mathrm{lei}^{485}$.

Conforme art. 43 citado, o incorporador que contratar a entrega da unidade a prazo e preços certos, determinados ou determináveis, modelo mais comum na incorporação imobiliária, não pode, sem justa causa devidamente comprovada, paralisar as obras por mais de trinta dias, ou retardar-lhes excessivamente o andamento, havendo procedimento previsto no inciso VI de referido artigo.

A lei assegura aos adquirentes (ou a qualquer interessado), nesse caso, a possibilidade de ir ao Judiciário para pleitear a retomada das obras, caso em que o julgador notificará o incorporador para que, no prazo de trinta dias, as reinicie ou torne a dar-lhes o andamento normal.

Há críticas quanto à redação do inciso, que define que o Judiciário determinará que seja retomada a obra no "prazo mínimo de 30 dias", entendendo-se, corretamente, que tal prazo deveria ser máximo ${ }^{486}$.

Tal medida não assegura integralmente os interesses dos adquirentes, pois há necessidade de acionamento do Judiciário, o que pode atrasar ainda mais a obra.

\footnotetext{
${ }^{484}$ "VI - se o incorporador, sem justa causa devidamente comprovada, paralisar as obras por mais de 30 dias, ou retardar-lhes excessivamente o andamento, poderá o Juiz notificá-lo para que no prazo mínimo de 30 dias as reinicie ou torne a dar-lhes o andamento normal. Desatendida a notificação, poderá o incorporador ser destituído pela maioria absoluta dos votos dos adquirentes, sem prejuízo da responsabilidade civil ou penal que couber, sujeito à cobrança executiva das importâncias comprovadamente devidas, facultando-se aos interessados prosseguir na obra;"

485، Art. 57. Ao construtor que contratar, por empreitada a preço fixo, uma obra de incorporação, aplicar-se-á, no que couber o disposto nos itens II, III, IV, (Vetado) e VI, do art. 43."

${ }^{486}$ Conforme PEREIRA, Caio Mário da Silva. Condomínio e incorporações, cit., p. 285 e ss.
} 
Caso não haja cumprimento à notificação, o incorporador poderá ser destituído pela maioria absoluta dos votos dos adquirentes, sem prejuízo da responsabilidade civil ou penal que couber, facultando-se aos interessados prosseguir na obra.

Ainda que a destituição do incorporador seja indicada como medida benéfica por Caio Mario $^{487}$, não garante que as obras serão retomadas de imediato, até mesmo pela hipossuficiência dos adquirentes, que dificilmente saberão lidar com as obras, e pelo fato de que poderá decorrer longo tempo para substituição por outro incorporador/construtor.

Adicionalmente, os adquirentes devem, por via executiva, cobrar as importâncias devidas pelo incorporador destituído, de forma que a retomada das obras será, possivelmente, impactada até o momento de restituição de valores já pagos pelos adquirentes e que estejam em posse do incorporador destituído, por não terem sido utilizados ainda na obra.

Cabe salientar que o art. 66 da lei, aplicável a qualquer modalidade de incorporação, define a paralisação ou o retardo da obra sem justa causa como contravenção relativa à economia popular. Trata-se de medida interessante, até mesmo por definir a solidariedade entre corretor, proprietário e construtor, caso o incorporador não figure no contrato incorporativo. Contudo, é de baixa aplicabilidade e inócua, sendo a sanção prevista, de multa de cinco a vinte vezes o salário mínimo, extremamente irrisória ${ }^{488}$.

Não obstante as críticas existentes ao procedimento de destituição previsto em lei, as medidas indicadas no art. 43, VI, não prejudicam a responsabilidade civil ou penal que couber.

Tal responsabilidade é prevista no art. 43, II, da lei em questão, definindo que o incorporador responde civilmente pela execução da incorporação, devendo indenizar os adquirentes caso não se conclua a edificação ou se houver demora injustificada nas obras.

Nesse caso, havendo contratação de entrega da unidade a prazo e preços certo, o que, na maior parte das vezes, se verifica, o incorporador é responsável pelo atraso.

\footnotetext{
${ }^{487}$ PEREIRA, Caio Mário da Silva. Condomínio e incorporações, cit., p. 287, assim expõe: "Invertendo-se a situação, armam-se os adquirentes de formidável poder. Na verdade, lançá-los nos azares de uma demanda para, ao fim da luta porfiada, conseguirem com a resolução do contrato a liberdade de prosseguir com outro incorporador ou tomarem diretamente a direção da edificação, sempre constituiu o maior obstáculo para que os interessados se movimentassem.".

488“'Art. 66. São contravenções relativas à economia popular, puníveis na forma do artigo 10 da Lei $\mathrm{n}^{\circ} 1.521$, de 26 de dezembro de 1951: (...); VI - paralisar o incorporador a obra, por mais de 30 dias, ou retardar-lhe excessivamente o andamento sem justa causa. PENA - Multa de 5 a 20 vezes o maior salário-mínimo legal vigente no País.".
} 
Aguiar Dias entende que o incorporador é responsável por qualquer dano causado pela inexecução ou má execução do contrato de incorporação, pois é ele quem figura no polo oposto da relação contratual mantida com os adquirentes ${ }^{489}$.

Com razão, deve-se atentar para o fato de que o incorporador é o propulsor do empreendimento e o responsável por este, nos termos do art. 31 da lei aplicável. Ainda que qualquer um dos agentes envolvidos possa ser considerado incorporador e que haja solidariedade entre eles, nos termos do parágrafo $3^{\circ}$ de aludido artigo, pode-se afirmar que há um incorporador que se coloca à frente da relação com o adquirente, que é indicado de forma expressa ao se lançar o empreendimento elou no local da construção.

Adicionalmente à solidariedade prevista, o incorporador, se não constrói diretamente, contrata o construtor, o que deve ser entendido como substituição.

Nesse sentido, não pode o incorporador alegar culpa de terceiro no caso de se fazer substituir na obrigação de construir por terceiro, ainda que se assegure ação regressiva contra o construtor, caso a demora ou impossibilidade de entrega do imóvel seja decorrente de ato ou fato a este imputável, nos termos do art. 43, II $^{490}$.

Ademais, há entendimento de que o incorporador não pode se eximir nem mesmo quando há inadimplência de outros adquirentes, em razão de assumir o risco do negócio ${ }^{491}$.

Entende-se que não é justo motivo para atraso nas obras a dificuldade de venda de unidades após o período de carência, uma vez que o incorporador possui esse prazo, quando ajustado, justamente para avaliar o mercado e o empreendimento que se pretende lançar. Caso não denuncie a incorporação após tal prazo, o incorporador assume o risco do negócio, de forma que não pode se eximir de responsabilidade pelo atraso na entrega do imóvel caso não receba a receita necessária para tanto, pela carência de adquirentes ${ }^{492}$.

\footnotetext{
${ }^{489} \mathrm{O}$ autor inclui as hipóteses de "(...)entrega retardada, de construção defeituosa, de inadimplemento total...". AGUIAR DIAS, José de. Responsabilidade civil em debate. Rio de Janeiro: Forense, 1983. p. 54.

${ }^{490}$ Chalhub, sinteticamente, afirma que o incorporador responde diretamente se se obrigar pela entrega pronta da unidade, se for o próprio construtor no caso de alienar inicialmente a fração ideal do terreno ou, de forma solidária com o construtor, se contratou a construção. CHALHUB, Melhim Namem. Da incorporação imobiliária, cit., p. 393-394.

${ }^{491}$ Segundo o julgamento da Apelação no $290520-4 / 0-00$, TJ/SP, "procedente a ação de adquirentes que não receberam o imóvel, em razão de atraso, declarando a resolução do contrato, com perdas e danos, não sendo causa para mora do incorporador a inadimplência de outros adquirentes, uma vez que o risco do negócio é do incorporador: (...)".

${ }^{492}$ CHALHUB, Melhim Namem. Da incorporação imobiliária, cit., p. 331.
} 
Ainda, entende-se que certos motivos que venham a obstar a entrega no prazo não podem ser considerados imprevisíveis ou fortuito, em razão da definição de fortuito interno, ou seja, inerente à atividade do incorporador ${ }^{493}$.

A demora na obtenção do habite-se, por exemplo ${ }^{494}$, é considerada fortuito interno, assumindo a incorporadora, assim, o risco correspondente, não sendo admissível que o incorporador alegue não haver atraso na entrega do imóvel por, mesmo antes de entregar as chaves ao adquirente, possuir o habite-se ${ }^{495}$, pois são obrigações diferentes.

Hipóteses como falta de material no mercado ou chuvas também são consideradas como não passíveis, via de regra, de invocação ${ }^{496}$.

Muitas decisões, com razão, embasam-se no Código de Defesa do Consumidor, especialmente na responsabilidade objetiva nele prevista, definindo-se, pois, o prazo

${ }^{493}$ De acordo com a lição de Cavalieri, já exposta, o fortuito interno guarda relação com a atividade do fornecedor, não o eximindo de responsabilidade (CAVALIERI FILHO, Sergio. Programa de direito do consumidor, cit., p. 256).

${ }^{494}$ Conforme exposto no julgamento, em 28.02.12, da AC no 0005485-19.2010.8.26.0361, do TJ/SP, $1^{\mathrm{a}}$ Câmara de Direito Privado, tendo como Rel. Des. Cláudio Godoy: “(...) Se por retardo na expedição do "habite-se", o risco é próprio da empreendedora e não pode ser transferido ao consumidor. Tem-se real fortuito interno, próprio da atividade profissional da construtora que, em ajuste de adesão, impôs e fixou, assim, o termo 'ad quem' para cumprimento de sua própria prestação...".

${ }^{495}$ Conforme Apelação Cível $n^{\text {o: }}$ 0036964-33.2013.8.19.0001, Vigésima Terceira Câmara Cível do TJ/RJ, Rel. Des. Lucio Durante, julg. em 04.12.13: “(...) Ocorre que no caso em tela, como bem ressaltou a Magistrada a quo, não houve justificativa para o atraso da entrega das chaves que deveria ocorrer em junho e só aconteceu em outubro (fls.52), sendo incabível a alegação de que já existia o "habite-se", pois sem a entrega das chaves o adquirente não teria como se mudar para o imóvel, logo, uma vez não comprovada a razão do impedimento, deve a Ré, que responde de forma objetiva pelos danos causados ao consumidor, arcar com a multa por atraso de $0,5 \%$ (zero vírgula cinco) sobre o valor da unidade reajustado monetariamente, por mês ou fração de atraso, estipulada no contrato na cláusula 17.6.1 às fls.36, desde 01/07/2012 até 09/10/2012, data em que foram entregues as chaves.".

${ }^{496}$ Como explana o nobre relator Des. Luiz Ambra, no julgamento, em 27.11.13, da Apelação $n^{\circ} 4000362-$ 87.2013.8.26.0224, da $8^{a}$ Câmara de Direito Privado do Tribunal de Justiça de São Paulo, em que houve confirmação da responsabilidade pelo atraso na entega, após o período de tolerância de 180 dias: “(...) O atraso na entrega do bem é inquestionável. Aqui, sequer tenta justificar atraso na entrega com a costumeira desculpa das fortes chuvas quiçá falta de material de construção no mercado ou de mão de obra qualificada, entre outros artifícios, que, ao menos num primeiro momento não tem como ser aceita. São ocorrências previsíveis e até esperadas no desempenho de suas atividades no campo da construção civil. De qualquer modo, não restou demonstrada a suposta ocorrência de caso fortuito ou de força maior. Aliás, as situações explicitadas são inerentes à atividade empresarial da ré e ao risco do próprio negócio, inclusive a incidência de condições climáticas adversas. O que não se pode admitir é tentar repassar ao consumidor esses ônus, exclusivos da atividade exercida pela construtora. (...)". (grifos da autora). Veja-se, oportunamente, haver a Súmula n. ${ }^{\circ} 94$ do TJ/RJ, que determina que "cuidando-se de fortuito interno, o fato de terceiro não exclui o dever do fornecedor de indenizar", bem como o Enunciado n. ${ }^{\circ} 442$, do Conselho da Justiça Federal: "O caso fortuito e a força maior somente serão considerados como excludentes da responsabilidade civil quando o fato gerador do dano não for conexo à atividade desenvolvida". No mesmo sentido, Apelação no 2012.057290-0, Segunda Câmara de Direito Civil, TJSC, Rel. Des. Monteiro Rocha, julg. em 31.10.2013: “(...)2. Excesso de chuvas e escassez de mão de obra não consubstanciam força maior para excluir a responsabilidade por atraso na entrega de obra, porquanto são riscos inerentes à construção civil, descabendo transferi-los ao consumidor adquirente". 
prescricional do art. 27 de tal Código para reparação de danos por falha na prestação de serviços $^{497}$.

Deve-se verificar, especificamente, a responsabilidade na modalidade de construção por administração, em que o incorporador/construtor é considerado mero cumpridor da vontade dos adquirentes, sendo estes os verdadeiros donos da obra.

Reitere-se que, nessa modalidade, os adquirentes dirigem a construção, por meio da Comissão de Representantes, cabendo ao condomínio dos adquirentes a responsabilidade em razão das deliberações quanto ao curso das obras, eximindo-se de responsabilidade, portanto, se houver culpa do construtor ou do incorporador no que se refere às suas respectivas obrigações.

Exemplificativamente, o construtor responsabiliza-se pela direção técnica e pelo fornecimento de mão-de-obra, cabendo aos adquirentes, por outro lado, a manutenção do fluxo financeiro para continuidade das obras, a aquisição e pagamento dos materiais e, repise-se, a direção geral das obras.

Depreende-se que a diferença, nessa modalidade, está adstrita à responsabilidade pelo custeio das obras, o que, de fato, pode afetar o andamento regular das obras. Contudo, essa modalidade não tem o condão de excluir a responsabilidade do incorporador pelo empreendimento em si.

Deve-se considerar que, ainda que a construção seja por administração, o incorporador procedeu ao projeto de construção e à sua aprovação pelas autoridades competentes, ao memorial descritivo das especificações da obra projetada e aos demais documentos relativos ao empreendimento, inclusive no que se refere à estipulação de prazo de entrega e à avaliação do custo global da obra.

\footnotetext{
${ }^{497}$ Por exemplo, o Agravo Interno na Apelação no 0040009-54.2009.8.19.0205, da Primeira Câmara Cível do TJ/ RJ, julg.em 10.12.13, tendo por Rel. Des. Lucia Helena do Passo : “(...)Convém ressaltar que a relação jurídica contratual estabelecida entre as partes é regida pelas normas consumeristas e, portanto, é de natureza objetiva a responsabilidade pelo fato do serviço, respondendo o fornecedor independentemente da comprovação de existência de culpa.". No julgamento do Agravo Interno na Apelação n ${ }^{\circ}$ 001031053.2011.8.19.0203, em 05.12.123, Vigésima Quinta Câmara Cível do TJ/RJ, tendo por Rel. Des. Cláudio Dell'Orto, demonstra-se que, por se tratar de relação consumerista, aplica-se o prazo do ar. 27, na ação de reparação por atraso na entregue: “(...) No que concerne aos demais pedidos, verifica-se que não há qualquer prescrição a ser declarada, aplicando-se, pois, o prazo prescricional de cinco anos previsto no art. 27, do CDC, uma vez que visam reparação dos danos causados pela falha na prestação dos serviços.".
} 
Ainda, conforme lição de Hely Lopes, independentemente da modalidade, a responsabilidade do construtor-administrador é legal, e não contratual, em razão do art. 618 , quanto a solidez, e profissional, conforme legislação regulamentadora da profissão ${ }^{498}$.

É o incorporador, pois, idealizador e propulsor do empreendimento, além de exercer atividade com fito de lucro.

Não pode, portanto, pretender se eximir de responsabilidade pelo atraso se não houver ato ou fato dos adquirentes que, realmente, contribua de forma relevante para o atraso na entrega do imóvel ${ }^{499}$, como é o caso da inadimplência dos próprios adquirentes que afete a evolução das obras ${ }^{500}$ ou decisão em assembleia quanto a não reajuste de parcelas ${ }^{501}$, ou se houver "comprovada falha na gestão do empreendimento" ${ }^{\text {"502 }}$, casos esses em que poderia estar presente a culpa da vítima.

\footnotetext{
${ }^{498}$ MEIRELLES, Hely Lopes. Direito de construir, cit., p. 224.

${ }^{499}$ Apelação no 0015732-49.2009.8.26.0602, da $8^{\text {a }}$ Câmara de Direito Privado do TJ/ SP, julg. em 02.10.13, tendo por Rel. Des. Salles Rossi: “(...) Portanto, não há que se falar em ilegitimidade passiva das construtoras/incorporadoras, mas sim da responsabilidade de ambas pela não conclusão da obra no prazo estipulado e na obrigação de devolver a apelado a integralidade dos valores pagos, vez que o autor não deu causa à rescisão do negócio.".

${ }^{500}$ Como decidido na Apelação 246.463-4/1-00, Rel. Paulo Eduardo Razuk, j. 01/12/2009, “(...) a invocação do sistema de construção pelo preço de custo não se presta a exculpar autêntico descumprimento contratual, oriundo de ausência de planejamento da incorporadora, mormente quando não comprovado o alto índice de inadimplência dos adquirentes do empreendimento, iterativamente alegado". Veja-se singelo acórdão do TJ/MG, na Apelação Cível 1.0155.07.014662-8/001, da 9a Câmara Cível, tendo por Rel. Des. José Antônio Braga, julg. em 24.08.10: "Ementa: CONSTRUÇÃO POR ADMINISTRAÇÃO - OBRA A PREÇO DE CUSTO - LEI 4.591/64 - ATRASO DAS OBRAS - PROPRIETÁRIOS - RESPONSABILIDADE. (...) Havendo inadimplência e deliberada, em Assembléia Geral, a prorrogação do prazo para a conclusão da obra, não há responsabilidade do incorporador.".

${ }^{501}$ Como se depreende do julgado do RExt RE 100084 / CE, Segunda Turma, STF, Rel. Min. Aldir Passarinho, julg. em 13.09.85, em que se se baseou na deliberação dos condôminos quanto ao não reajuste das prestações, apesar do aumento na mao de obra e nos materiais: "CONDOMINIOS. CONSTRUÇÃO POR ADMINISTRAÇÃO. PARALISAÇÃO DAS OBRAS. TENDO SIDO A DEMORA NO PROSSEGUIMENTO DAS OBRAS DE CONSTRUÇÃO DE EDIFICIO DE APARTAMENTOS, CONTRATADA PELO REGIME DE ADMINISTRAÇÃO, RESULTANTE DE DECISÃO DA ASSEMBLÉIA DE NÃO REAJUSTAR OS PREÇOS DAS PRESTAÇÕES, APESAR DO AUMENTO DO PREÇO DOS SERVIÇOS E DO MATERIAL, A RESPONSABILIDADE PELO CUSTO DA OBRA CABE AOS CO-PROPRIETARIOS OU ADQUIRENTES, TENDO-SE QUE EMBORA A CONSTRUTORA POSSUISSE, QUANDO DA DELIBERAÇÃO, COTAS COM DIREITO A VOTO, CORRESPONDIAM ELAS A APENAS 25 DE UM TOTAL DE 80. NAS ASSEMBLÉIAS DE CONDOMINIOS E BASTANTE FREQUENTE UMA MINORIA ATUANTE FAZER PREVALECER SEUS PONTOS DE VISTA PELA OMISSAO DA MAIORIA, A BASE AS VEZES ATÉ DE INTERESSES INJUSTIFICAVEIS, COM PREJUIZOS PARA OS ÚLTIMOS QUE PAGAM PELO SEU COMODISMO OU DESINTERESSE. NÃO CONHECIMENTO DO RECURSO PELA LETRA 'A' SE NÃO FOI APONTADO QUALQUER DISPOSITIVO LEGAL QUE PUDESSE INVALIDAR A DELIBERAÇÃO DA ASSEMBLÉIA, TOMADA POR MAIORIA DE VOTOS DOS PRESENTES; NEM PELA LETRA 'D' SE NENHUM ACÓRDÃO DIVERGENTE FOI TRAZIDO A BAILA."

${ }^{502}$ Apelação Cível no 0017399-92.2007.8.19.0066, Décima Oitava Câmara Cível do TJ/RJ, Rel. Des. Heleno Ribeiro Pereira Nunes, julg. em 26.04.12.
} 
Há julgados decidindo pela responsabilidade da incorporadora/construtora pelo atraso, apesar de se tratar de construção por administração, por exemplo, em caso de não haver atuação administrativa da Comissão de Representantes ${ }^{503}$ ou por ter esta função esvaziada $^{504}$, em caso de ser a incorporadora de fato quem “(...) tinha plenos poderes e disponibilidade sobre os valores e sobre a condução das obras" 505 , ou "por se tratar de oferta pública para prazo de entrega sem qualquer ressalva de eventual demora justificável pelo regime contratual"

Considerando que o legislador previu expressamente a indenização tanto pela mora, caracterizada pela demora injustificada, quanto pelo inadimplemento, caracterizado pela não conclusão da edificação, ao adquirente cabe o pleito indenizatório em ambos os casos, bem como a aplicação de cláusula penal eventualmente prevista e, eventualmente, o direito à resolução do contrato, com base no art. 395 do Código Civil.

\footnotetext{
${ }^{503}$ No julgamento da Apelação 9104409-93.2008.8.26.0000, pela $1^{\text {a }}$ Câmara Extraordinária de Direito Privado do TJ/SP, em 10.12.13, tendo por Relatora Marcia Regina Dalla Déa Barone, foi assim exposto: “(...) A requerida figurou no contrato firmado pelas partes como Construtora e Incorporadora, e assim atuou na gestão da obra sem que a comissão de condôminos, formalmente firmada nos termos da Lei $n^{\circ}$ 4591/64, mas sem qualquer atuação administrativa, pudesse interferir nas decisões administrativas. Anota-se que ao adquirir o terreno e propor ao público a aquisição de unidades habitacionais, que garantiriam lucro à construtora, revelou-se inequívoca relação de consumo que deve ser protegida.

Não há como afastar, desta forma, legitimidade passiva da construtora para figurar na presente lide, podendo a mesma voltar-se, através de ação própria, contra quem lhe teria causado danos, mas perante os adquirentes a requerida deve responder.(...)".

${ }^{504}$ De acordo com decisão da Apelação n. 0019427-24.2010, da $8^{\text {a }}$ Câmara de Direito Privado do TJ/SP, tendo como Rel. o Des. Caetano Lagrasta, julg. em 08.0513, cuja ementa é a seguinte: "Rescisão contratual c.c. restituição das quantias pagas. Construção por administração ("a preço de custo"). Título II, capítulo III, seção III da Lei $n^{\circ}$ 4591/64. Atraso na entrega de obra. Sentença improcedente. Descaracterização do instituto. Legitimidade passiva. Comissão de Representantes com função esvaziada. Movimentação financeira toda a cargo das requeridas. Precedente do STJ. Caso excepcional que autoriza devolução integral das parcelas pagas. Apelo provido.".

${ }^{505}$ Como indicado na Apelação $n^{\circ}$ 9161128-61.2009.8.26.0000, $1^{\text {a }}$ Câmara de Direito Privado do TJ/SP, Rel. Des. Claudio Godoy, julg. em 17.09.13, cuja ementa é a seguinte: "Compromisso de compra e venda. Resolução por atraso injustificado na entrega da obra. Alegação de construção sob o regime de preço de custo. Regime, porém, desvirtuado. Incorporadora e administradora da construção que movimenta com exclusividade a conta bancária em que depositadas as parcelas. Pagamento, ademais, de valores que diretamente a ela se fizeram. Responsabilidade, também, ante o descumprimento da própria obrigação de bem gerir a construção da obra, iniciada em 1992 e, até o momento, não concluída. Sentença revista. Recurso provido.".

${ }^{506}$ Conforme exposto na Apelação Cível no 497.724-4/0, citada no julgamento da Apelação Cível Com Revisão n ${ }^{\circ}$ 569.929-4/4-00, da Oitava Câmara de Direito Privado, TJ/SP, Rel. Des. Salles Rossi, julg. em, 26 de junho de 2008: "CONTRATO Aquisição de imóvel pelo regime de preço de custo Inadimplemento dos contratantes posterior ao término do prazo a que se obrigou a contratada para entrega das obras Irrelevância do regime adotado no contrato, porque a construtora fez oferta pública para prazo de entrega sem qualquer ressalva de eventual demora justificável pelo regime contratual Oferta pública de prazo sem ressalva integra o contrato, por força do art. 30, Código de Defesa do Consumidor Rescisão contratual verificada pelo primeiro inadimplemento da construtora, que justificou a falta de pagamento posterior dos autores Danos morais inocorrentes Ação parcialmente procedente, para declaração de rescisão contratual e devolução das quantias pagas Recursos não providos."
} 
Importante medida de segurança ao adquirente é a imposição de multa moratória em contrato, em caso de atraso na entrega do imóvel.

Como já exposto, a cláusula penal tem efeito facilitador por ser desnecessária a comprovação de qualquer dano decorrente da mora ou do inadimplemento.

Nesse sentido, cabe mencionar interessantes iniciativas do Ministério Público de determinados Estados, no sentido de firmar termos de conduta relacionados ao assunto. Exemplificativamente, o Ministério Público do Distrito Federal celebrou com a ADEMI de Brasília (Associação de Empresas do Mercado Imobiliário do Distrito Federal) ${ }^{507}$, termo n $^{\circ}$ 603/09, estipulando que o valor da multa pelo atraso na obra seria o mesmo da multa estabelecida pela não devolução do imóvel pelo adquirente em caso de resolução do contrato por inadimplemento deste. Ainda, celebrou outros termos semelhantes, como os $638 / 10,644 / 11$ e $700 / 13^{508}$.

Em São Paulo, o Ministério Público havia firmado termo de conduta com o SECOVI (Sindicato das Empresas de Compra, Venda, Locação e Administração de Imóveis Residenciais e Comerciais de São Paulo), em 2011, para definir a regulação do prazo estimado de entrega e do prazo de tolerância, até 180 dias, sujeitando a incorporadora que descumprir tais regras à multa compensatória de $2 \%$ sobre o valor já pago pelo adquirente à incorporadora responsável pela obra e à multa moratória, no valor correspondente a $0,5 \%$ ao mês (ou fração, calculado pro rata dies) do valor até então por ele pago ${ }^{509}$. Contudo, o Conselho Superior do Ministério Público, em junho de 2012, deixou de homologar referido termo, por entender que esse termo ratificava ou incentivava prática de prever tolerância para a incorporadora, com o que, entendeu-se, não se podia concordar, já que ao adquirente não é concedida nenhuma tolerância em relação a suas obrigações $^{510}$.

\footnotetext{
${ }^{507}$ CHALHUB, Melhim Namem. Da incorporação imobiliária, cit., p. 330.

${ }^{508}$ Todos disponíveis em MINISTÉRIO PÚBLICO DO DISTRITO FEDERAL E TERRITÓRIOS. Promotoria de Justiça de Defesa dos Direitos do Consumidor - Prodecon. Disponível em: $<$ http://www.mpdft.mp.br/portal/index.php/mpdft-acao/termos-de-ajustamento-de-conduta/3166promotoria-de-justica-de-defesa-dos-direitos-do-consumidor-prodecon>. Acesso em: 19 set. 2013.

${ }^{509}$ Conforme notícia MP e SECOVI firmam TAC para incorporadoras incluírem nos contratos cláusulas sobre atraso em obras. Disponível em: <http://www.mp.sp.gov.br/portal/page/portal/noticias/publicacao_noticias/2011/outubro_2011/MP\%20e\%2 0SECOVI\%20firmam\%20TAC\%20para\%20incorporadoras\%20inclu\%C3\%ADrem\%20nos\%20contratos \%20c1\%C3\%A1usulas\%20sobre\%20atraso\%20em\%20obras>. Acesso em: 19 set. 2013.

${ }^{510}$ BEZERRA, Elton. Conselho do MP veta TAC que permitia atraso em obras. Consultor Jurídico, 26 jun. 2012. Disponível em: <http://www.conjur.com.br/2012-jun-26/conselho-mp-derruba-tac-permitiaconstrutoras-atrasar-entrega>. Acesso em: 19 set. 2013.
} 
Apesar de compreensível a preocupação do Conselho Superior do Ministério Público, trata-se de prática comum ${ }^{511}$, sendo pertinente apenas limitar o prazo de tolerância, de forma que não afete sobremaneira a expectativa de recebimento da unidade pelos adquirentes.

Ressalte-se a admissibilidade de cumulação da cláusula penal moratória e da execução de obrigação ${ }^{512}$, que, como vimos, refere-se a obrigação de fazer se a coisa não estiver pronta e acabada, aplicando-se o regramento atinente a essa espécie de obrigação, tanto o previsto no Código Civil, quanto o no Código de Processo Civil, sem afastar as previsões específicas contidas no Código de Defesa do Consumidor.

A multa contratual prevista não se confunde com a multa cominatória que pode ser imposta em ação de cumprimento pelo juiz, em caso de descumprimento da decisão judicial, sendo muito comum e mesmo pertinente tal imputação, de forma a coibir novo descumprimento pelo incorporador.

Nesse sentido, permite-se a execução, a cargo do incorporador, por terceiro, uma vez que não se pode interpretar que a obrigação do incorporador é infungível, até mesmo

\footnotetext{
${ }^{511}$ Não obstante, vale ressaltar que é tido como perfeitamente lícito ao incorporador incluir no contrato a chamada cláusula de tolerância, que prevê prazo suplementar para entrega do imóvel. Nesse sentido, acórdão do julgamento de 06.06.2013 da Apelação ${ }^{\circ}$ 0222210-72.2011.8.26.0100, pela $4^{a}$ Câmara de Direito Privado do Tribunal de Justiça de São Paulo, tendo como Relator Des. Maia da Cunha: "Compromisso de venda e compra de imóvel em construção. Inexistência de abusividade de cláusula de tolerância de 180 dias para atraso na entrega do bem. Atraso além deste período que deve ser indenizado, pois a construtora não comprovou culpa do comprador pela demora na entrega das chaves. (...)”.

${ }^{512}$ Trazemos, em relação à cumulação da execução da obrigação e da multa moratória, acórdão do Superior Tribunal de Justiça, referente ao julgamento do REsp 1355554 / RJ, Terceira Turma, Relator Ministro Sidnei Beneti, de 06/12/2012, conforme ementa: "DIREITO CIVIL. PROMESSA DE COMPRA E VENDA DE IMÓVEL EM CONSTRUÇÃO. INADIMPLEMENTO PARCIAL. ATRASO NA ENTREGA DO IMÓVEL. MORA. CLÁUSULA PENAL. PERDAS E DANOS. CUMULAÇÃO. POSSIBILIDADE. 1.- A obrigação de indenizar é corolário natural daquele que pratica ato lesivo ao interesse ou direito de outrem. Se a cláusula penal compensatória funciona como pré-fixação das perdas e danos, o mesmo não ocorre com a cláusula penal moratória, que não compensa nem substitui o inadimplemento, apenas pune a mora. 2.- Assim, a cominação contratual de uma multa para o caso de mora não interfere na responsabilidade civil decorrente do retardo no cumprimento da obrigação que já deflui naturalmente do próprio sistema. 3.- O promitente comprador, em caso de atraso na entrega do imóvel adquirido pode pleitear, por isso, além da multa moratória expressamente estabelecida no contrato, também o cumprimento, mesmo que tardio da obrigação e ainda a indenização correspondente aos lucros cessantes pela não fruição do imóvel durante o período da mora da promitente vendedora.4.- Recurso Especial a que se nega provimento.”.Previsão nesse sentido nos seguintes julgados, exemplificativamente: Apelação Cível $\mathrm{n}^{\mathrm{o}}$ 0138577-32.2012.8.26.0100, $7^{\mathrm{a}}$ Câmara de Direito Privadodo TJ/SP, julgada em 11/12/2013, tendo por Rel. Des. Luis Mario Galbetti; Apelação Cível no 0016350-21.2011.8.26.0344, 10ª Câmara de Direito Privado, julgada em 26/11/2013, tendo por Rel. Des. Carlos Alberto Garbi; Apelação Cível no 001848606.2011.8.19.0208, da Décima Primeira Câmara Cível do TJ/RJ, julgada em 11.12.13, tendo por Rel. Des. Roberto Guimaraes; Apelação Cível no 0266442-39.2012.8.19.0001, Nona Câmara Cível do TJ/RJ, julgada em 10.12.13, tendo por Rel. Des. Roberto de Abreu e Silva; entre muitas outras.
} 
pela existência de hipóteses legais de destituição do incorporador e prosseguimento das obras por outro, inclusive no caso de instituição de patrimônio de afetação.

Ainda, é cabível a ação para obter a resolução do contrato, sendo admissível, como outrora mencionado, tal pleito até mesmo na hipótese de inadimplemento do adquirente.

Em caso de resolução por atraso na entrega do imóvel, é comum o pedido, pelo adquirente, de indenização pelos danos decorrentes, o que, em geral, inclui os lucros cessantes, caracterizados pelo pagamento de valor de potencial fruição do imóvel ${ }^{513}$.

Questão muito discutida é referente à devolução dos valores, inclusive a taxa de corretagem que os incorporadores imputam aos adquirentes comumente.

José Osório de Azevedo Junior entende que se o incorporador definiu como de responsabilidade do adquirente o pagamento do corretor, o valor respectivo integra o preço de aquisição. Assim, se houver hipótese de devolução do preço, o valor de corretagem também deve ser devolvido ${ }^{514}$.

Entretanto, diversas decisões reiteram entendimento de que, se houver previsão expressa nesse sentido no contrato correspondente, lícita é a cobrança ${ }^{515}$. Igualmente lícita é a retenção de valor atinente a tal taxa, em caso de resolução ${ }^{516}$.

\footnotetext{
${ }^{513}$ No processo no $2012.01 .1 .012756-7$, do Tribunal de Justiça do Distrito Federal e Territórios, o juiz da $25^{\text {a }}$ Vara Cível de Brasília declarou a extinção do contrato de compra e venda firmado entre uma incorporadora (S. Construções) e a adquirente, em razão do atraso na entrega do imóvel, determinando a devolução das parcelas pagas, de forma integral, bem como o pagamento de aluguéis de $1 \%$ sobre o valor do bem, a título de lucros cessantes, desde a data prevista para a entrega até a data da sentença.

${ }_{514}^{514}$ AZEVEDO JR., José Osório de. Compromisso de compra e venda, cit., p. 291.

${ }^{515}$ No sentido de que só é lícita a cobrança se expressamente prevista, Apelação Cível no 001848606.2011.8.19.0208, Décima Primeira Câmara Cível do TJ/RJ, julgada em 11.12.13, tendo por Rel. Des. Roberto Guimarães: (...) Todavia, não há nos autos provas de que a informação da responsabilidade pelo pagamento da comissão de corretagem tenha sido devidamente prestada aos Apelantes, eis que não há referência a essa na escritura de compra e venda e a Apelada não trouxe aos autos qualquer documento provando que os mesmos tinham ciência da referida cobrança. Neste panorama, como não há provas de que os Apelantes tinham ciência da cobrança e de que anuíram com este pagamento, a referida comissão deve ser restituída aos Apelantes na forma do artigo 42, parágrafo único do Código de Defesa do Consumidor.”.

${ }^{516}$ Já foi analisada a vedação, constante do Código de Defesa do Consumidor, da perda integral do valor pago pelo adquirente, sendo admissível, contudo, a retenção de valores e a diminuição do valor a ser restituído em razão de prejuízos causados ao vendedor/incorporador, inclusive em relação à taxa de corretagem. Nesse sentido, REsp 1224921 / PR Ministra NANCY ANDRIGH TERCEIRA TURMA, STJ, julg. em 26/04/2011: "DIREITO CIVIL. PROMESSA DE COMPRA E VENDA DE IMÓVEL. RESCISÃO. INADIMPLÊNCIA DO COMPRADOR. DEVOLUÇÃO DOS VALORES PAGOS. CABIMENTO. RETENÇÃO DE PARTE DOS VALORES PELO VENDEDOR. INDENIZAÇÃO PELOS PREJUÍZOS SUPORTADOS. CABIMENTO. ARRAS. SEPARAÇÃO. 1. A rescisão de um contrato exige que se promova o retorno das partes ao status quo ante, sendo certo que, no âmbito dos contratos de promessa de compra e venda de imóvel, em caso de rescisão motivada por inadimplência do comprador, a jurisprudência
} 
Não se pode deixar de observar que há uma comunhão de interesses dos adquirentes e estes têm representação coletiva assegurada pela lei, por meio da Comissão de Representantes e da Assembleia dos contratantes, permitindo-lhes a fiscalização do andamento da obra, entre outras providências relevantes, especialmente na modalidade de construção por administração.

Independentemente da modalidade, exercendo adequadamente o direito de fiscalização que lhe é assegurado, o adquirente pode agir de forma a evitar surpresas em relação à entrega da coisa, sendo útil, inclusive, para caracterizar o inadimplemento antecipado, uma vez que permite que os adquirentes verifiquem o andamento das obras e tenham, se o caso, subsídios para alegar, previamente ao termo final, que a obrigação não será adequadamente cumprida ${ }^{517}$.

Interessante questão, que oferece maior suporte aos adquirentes, é a previsão constante do parágrafo $3^{\circ}$ do art. $5^{\circ}$ da Lei no 9.514/97 de que, na incorporação imobiliária, poderá ser contratado seguro que garanta ressarcimento ao adquirente das quantias por ele pagas, na hipótese de inadimplemento do incorporador quanto à entrega da obra.

Deve-se ressaltar que a norma prevê que a contratação de tal seguro fica a critério do adquirente e se faz mediante informação obrigatória do incorporador nesse sentido,

\footnotetext{
do STJ se consolidou no sentido de admitir a retenção, pelo vendedor, de parte das prestações pagas, como forma de indenizá-lo pelos prejuízos suportados, notadamente as despesas administrativas havidas com a divulgação, comercialização e corretagem, o pagamento de tributos e taxas incidentes sobre o imóvel e a eventual utilização do bem pelo comprador.". Em sentido contrário, decisão que se baseou no Código de Defesa do Consumidor e na proibição de venda casada: “(...) Certo que não se impediria, em regra, o ajuste para que o mesmo pagamento ao comprador se transferisse. Mas não cabe olvidar ter-se, na espécie, relação de consumo, em que nada a respeito se ajusta, senão se impõe ao consumidor. E, pior, como condição a que possa consumar a compra da unidade. Aí, justamente, a venda casada. (...)" (Apelação no 400154021.2013.8.26.0564, $1^{\text {a }}$ Câmara de Direito Privado, TJ/SP, REl. Des. Claudio Godoy, julg. em 17.12.13).

${ }^{517}$ Como regra geral, havendo prazo para determinada prestação, impõe-se, em regra, aguardar a realização do termo final, de forma que se possa caracterizar o descumprimento pelo devedor. Enquanto o termo final para cumprimento de determinada obrigação não for alcançado, não se pode afirmar que o devedor está em mora ou inadimplente. Contudo, aplicando-se a teoria do inadimplemento antecipado, já mencionada, permite-se que o credor aja previamente ao termo final, de forma a evitar maiores prejuízos advindos da mora ou do inadimplemento. Para maiores esclarecimentos sobre a teoria em questão, ver AZULAY, Fortunato. Do inadimplemento antecipado do contrato, cit.; TERRA, Aline de Miranda Valverde. Inadimplemento anterior ao termo, cit.; LABORIAU, Miguel. Algumas considerações sobre o inadimplemento antecipado no direito brasileiro. Revista Trimestral de Direito Civil, Rio de Janeiro, ano 11, v. 42, p. 93-130, abr./jun. 2010; MARTINS, Raphael Manhães. Inadimplemento antecipado: perspectiva para sua aplicação no direito brasileiro. Revista Forense, Rio de Janeiro, v. 103, n. 391, p. 159188, maio/jun. 2007.
} 
sendo que o custo correspondente, por se tratar de questão negocial, pode ser de responsabilidade do incorporador ou pode ser incorporado ao preço de aquisição ${ }^{518}$.

Segundo Chalhub ${ }^{519}$, seguro com mesmo intuito que o da Lei $n^{\circ}$ 9.514/97 é o seguro-garantia, contratado por todos os adquirentes, já que o cumprimento da obrigação da seguradora é concluir a obra. O seguro garante indenização dos prejuízos decorrentes do inadimplemento do incorporador em relação às obrigações assumidas no contrato de construção e inclui o custo de acréscimo na construção da obra, podendo optar a seguradora por efetuar o ressarcimento das importâncias pagas pelo adquirente ao incorporador até a data do inadimplemento ou promover os atos necessários para conclusão da obra.

Ressalte-se que o art. 20 do Decreto-Lei $n^{\circ} 73 / 66$, que dispõe sobre o Sistema Nacional de Seguros Privados, regula as operações de seguros e resseguros e dá outras providências, define como obrigatória a contratação do seguro de garantia do cumprimento das obrigações do incorporador e do construtor, entre outros ${ }^{520}$.

Mediante contratação do seguro, há maior segurança aos adquirentes, tendo em vista que, independentemente do motivo que gerou o descumprimento por parte do incorporador, se garante a restituição de valores àqueles.

Na Espanha, conforme exposto, há obrigação de contratação de seguro ou fiança para garantia da devolução de valores nas hipóteses em que o imóvel não foi ou não será entregue conforme previsto. A lei $n^{\circ} 57 / 68$ menciona que se transcorrido o prazo de início das obras ${ }^{521}$ ou de entrega do imóvel, sem que isso tenha ocorrido, o adquirente poderá optar pela resolução do contrato, mediante devolução dos valores, com juros anuais de $6 \%$, caso não pretenda conceder prazo suplementar ao promotor $^{522}$.

\footnotetext{
${ }^{518}$ Art. $5^{\circ}$ As operações de financiamento imobiliário em geral, no âmbito do SFI, serão livremente pactuadas pelas partes, observadas as seguintes condições essenciais: $\S 3^{\circ} \mathrm{Na}$ alienação de unidades em edificação sob o regime da Lei $\mathrm{n}^{\circ}$ 4.591, de 16 de dezembro de 1964, a critério do adquirente e mediante informação obrigatória do incorporador, poderá ser contratado seguro que garanta o ressarcimento ao adquirente das quantias por este pagas, na hipótese de inadimplemento do incorporador ou construtor quanto à entrega da obra.

${ }^{519}$ CHALHUB, Melhim Namem. Da incorporação imobiliária, cit., p. 216-217.

${ }^{520}$ Cuja redação é a seguinte: "Sem prejuízo do disposto em leis especiais, são obrigatórios os seguros de: (...) e) garantia do cumprimento das obrigações do incorporador e construtor de imóveis;".

${ }^{521}$ Em clara previsão da possibilidade de declaração de inadimplemento antecipado, considerando que o marco para verificação do descumprimento seria o prazo final de entrega do imóvel.

522“"Artículo tercero. Expirado el plazo de iniciación de las obras o de entrega de la vivienda sin que una u otra hubiesen tenido lugar, el cesionario podrá optar entre la rescisión del contrato con devolución de las cantidades entregadas a cuenta, incrementadas con el seis por ciento de interés anual, o conceder al cedente prórroga, que se hará constar en una cláusula adicional del contrato otorgado, especificando el nuevo período con la fecha de terminación de la construcción y entrega de la vivienda.”.
} 
Aludidos remédios são adicionais à responsabilidade do promotor pela entrega da coisa ${ }^{523}$.

Apesar dos diversos remédios colocados à disposição dos adquirentes, entende-se que estes oneram adicionalmente, como em relação à contratação de seguros, ou os sujeitam à intervenção judicial, não havendo, de forma ampla, conhecimento acerca dos direitos inerentes aos adquirentes, ou mesmo acesso ao Judiciário.

Cabe, assim, a imposição de meios facilitadores e que independam do acionamento do Judiciário ou medidas que tenham o condão de inibir o descumprimento pelos incorporadores. Nesse sentido, vislumbra-se a pertinência de intensificação da responsabilidade penal prevista na lei, de inclusão de meios coercitivos próprios, que afetem diretamente o patrimônio do incorporador, ou mesmo da fiscalização por órgão específico da atuação dos incorporadores no mercado ${ }^{524}$.

\subsubsection{Ausência de averbação da obra e de habite-se}

É pertinente avaliar a ausência de averbação da obra e do "habite-se", que impede a utilização do imóvel pelo adquirente.

Reitere-se que, para extinção regular do contrato de incorporação imobiliária, fazse necessária a regularização da edificação mediante obtenção de habite-se e averbação da construção, de forma que a unidade autônoma possa ser entregue de forma adequada, apta ao uso a que se destina.

Foi verificado que a demora na obtenção do habite-se não pode ser causa de isenção de responsabilidade do incorporador, por se tratar de providência necessária e previsível, inerente à atividade incorporativa e à entrega plena da coisa contratada ${ }^{525}$.

\footnotetext{
${ }^{523}$ Segundo Luis Antonio Soler Pascual, "También deberá informarse sobre la fecha de entrega y la fase en que en cada momento se encuentra la edificación. Este aspecto es relevante pues deberá incorporarse, normalmente, al contrato formalizado mediante documento privado para que, así, el posterior retraso en la entrega pueda dar lugar a la responsabilidad por mora o a la exigencia de la garantía contenida en la Ley 57/1968, de 27 de julio." (SOLER PASCUAL, Luis Antonio. Los consumidores ante la adquisición de un bien inmueble en proyecto o en fase de contrucción, cit.).

${ }^{524}$ Veja-se que Caio Mario já criticava a ausência de fiscalização específica do setor. PEREIRA, Caio Mário da Silva. Condomínio e incorporações, cit., p. 257.

${ }^{525}$ Nesse mesmo sentido, acórdão do Tribunal de Justiça de São Paulo: (...) Antes da expedição do "habite-se", o imóvel não pode ser considerado como regularizado, impossibilitando sua aceitação plena, por parte do comprador. Portanto, não há como deixar de reconhecer a mora.”. Apelação no 0035899-31.2010.8.26.0577, $5^{\text {a }}$ Câmara de Direito Privado, Rel. Edson Luiz de Queiroz, j. em 11 de dezembro de 2013.
} 
Assim, tem-se que a responsabilidade do incorporador de entregar o bem em determinado prazo só se encerra após a obtenção de tais providências.

Cabe reiterar que o art. 44 da Lei $\mathrm{n}^{\mathrm{o}} 4.591 / 64^{526}$ prevê expressamente a responsabilidade civil do incorporador perante os adquirentes pelo prejuízo decorrente da demora na averbação da construção das edificações.

E, em caso de omissão do incorporador em relação a essa obrigação, deve o construtor realizar a averbação, sob pena de, não o fazendo, responder solidariamente com o incorporador pelo prejuízo causado na demora ${ }^{527}$.

Como exposto, considerando que a lei não prevê prazo específico para tal providência, deve-se entender que essa obrigação tem termo final coincidente com o termo final da entrega do imóvel.

Apesar de a lei prever que qualquer interessado pode requerer a averbação, não se deve interpretar a omissão do adquirente como causa de excludente de responsabilidade do incorporador ou do construtor, conforme o caso.

Outra hipótese a ser aventada relaciona-se à dificuldade de obtenção do habite-se ou da averbação da construção.

Vimos que o habite-se atesta a conclusão da obra com observância da legislação e do projeto inicial de construção.

Para averbação da construção, os Cartórios de Registro de Imóvel costumam requerer a apresentação de diversos documentos que atestem as autorizações para construir, a conclusão da obra (como o habite-se), entre outros documentos técnicos.

\footnotetext{
526، "Art. 44. Após a concessão do "habite-se" pela autoridade administrativa, o incorporador deverá requerer, (VETADO) a averbação da construção das edificações, para efeito de individualização e discriminação das unidades, respondendo perante os adquirentes pelas perdas e danos que resultem da demora no cumprimento dessa obrigação. $\S 1^{\circ}$ Se o incorporador não requerer a averbação (VETADO) o construtor requerê-la-á (VETADO) sob pena de ficar solidàriamente responsável com o incorporador perante os adquirentes.§ $2^{\circ} \mathrm{Na}$ omissão do incorporador e do construtor, a averbação poderá ser requerida por qualquer dos adquirentes de unidade.".

${ }^{527}$ No sentido de haver solidariedade do construtor apenas se omisso o incorporador: "Direito Civil. Incorporação imobiliária. Responsabilidade solidária do construtor prevista no $\S 1^{\circ}$ do art. 44 da Lei n. 4.591/64. Obtenção do 'habite-se'. Obrigação do incorporador. - Em princípio, é do incorporador a obrigação de obtenção do 'habite-se' junto à autoridade competente. - A responsabilidade solidária do construtor, prevista no $\S 1^{\circ}$ do art. 44 da Lei n. 4.591/64, ocorre apenas se o mesmo não requerer a averbação das edificações no Registro de Imóveis, após a obtenção do 'habite-se' pelo incorporador e a omissão deste em requerer a mencionada averbação.” (REsp 441.236/RJ, Terceira Turma, STJ, Rel. Min.Nancy Andrighi, julg. em 10.06.03).
} 
Dessa forma, depreende-se que qualquer dificuldade com a realização de tais providências estará relacionada, via de regra, com a irregularidade na construção.

Sendo assim, parece razoável afirmar que haverá responsabilidade do incorporador ou do construtor, conforme o caso ${ }^{528}$, e não obstante a solidariedade existente entre eles, pela não obtenção do habite-se ou por não se conseguir averbar a construção.

Merece destaque a opinião de Scartezzini, de que a venda de um imóvel sem o respectivo "habite-se" é caso de inadimplemento, não se tratando de vícios redibitórios, por ser vício de direito e não da coisa em si $^{529}$.

Tal entendimento vai ao encontro do entendimento de doutrinadores e julgadores italianos, ao definir que a ausência do "certificato di abilità", sendo este requisito jurídico essencial, não permite que a coisa atinja seu fim econômico e social, quando a venda tem fins de habitação, sendo, assim, caso de inadimplemento aliud pro alio, permitindo a resolução do contrato ${ }^{530}$.

Dessa forma, evidente a responsabilidade dos agentes envolvidos na incorporação em razão da não obtenção do "habite-se" e da providência de averbação da construção, por inadimplemento da obrigação de resultado prevista na incorporação, que é entregar a unidade autônoma individualizada e pronta para utilização, no prazo acordado.

\footnotetext{
${ }^{528}$ Ou de outros agentes envolvidos, como expõe o julgado a seguir: “(...) E a irregularidade da incorporação é confessada, porque não existe registro, tampouco averbação das unidades negociadas. A exigir a responsabilidade solidária, imputável tanto aquele que é proprietário do terreno, como do construtor ou responsável pelo investimento. É o que se infere do art. 31, letras "A" e "B", da Lei no 4.591/64. Na realidade, a condição ostensiva do incorporador (...) não encobre a responsabilidade de seus sócios e dos titulares do imóvel.(...)". Apelação Cível no 70013986641, Vigésima Câmara Cível, TJ/RS, Rel. Des. José Aquino Flôres de Camargo, julg. em 22.02.06.

${ }^{529}$ GUIMARÃES, Paulo Jorge Scartezzini. Vícios do produto e do serviço por qualidade, quantidade e insegurança: cumprimento imperfeito do contrato, cit., GUIMARÃES, Paulo Jorge Scartezzini. Vícios do produto e do serviço por qualidade, quantidade e insegurança: cumprimento imperfeito do contrato, cit., p. 95 e 171.

${ }^{530}$ Savanna entende dessa forma e cita entendimento jurisprudencial nesse sentido.Cass. 26 gennaio 2006, $\mathrm{n}^{\circ}$ 1514, in Giust. Civ. Mass., 2006, fasc 1, Cass. 25 febbraio 2002, no 2729, in Giust. Civ. Mass., 2002, pag. 301, entre outros. SAVANNA, Lidia. La compravendita garanzia per vizi della cosa venduta e nuova tutela del consumatore, cit., p. 37-39. Bem como Roberto Triola, Vendita di immobili da costruire e tutela dell'acquirente, cit., p. 185-186.
} 


\subsubsection{Desconformidade com projeto e especificações}

Neste item, serão avaliadas as condições de entrega da coisa que envolvem cumprimento imperfeito, especialmente a responsabilidade do incorporador em razão de vícios qualitativos, como o imóvel em desconformidade com as especificações do memorial de incorporação e do contrato celebrado, incluindo-se defeitos na construção ${ }^{531}$.

Repise-se que é obrigação do incorporador seguir estritamente o projeto de construção registrado com o memorial de incorporação, sendo vedado alterá-lo, modificar as especificações ou se desviar do plano da construção, nos termos do art. 43, IV, sendo o projeto e o memorial descritivo das edificações parte integrante e complementar do contrato, nos termos do parágrafo $1^{\circ}$ do art. 48, aplicável a qualquer modalidade de construção.

Nas contratações pela modalidade de empreitada, o art. $55, \S 3^{\circ}$, prevê que a Comissão de Representantes fiscalizará o andamento da obra e a obediência ao Projeto e às especificações.

Apesar da fiscalização pela Comissão de Representantes, é obrigação do incorporador seguir as especificações do empreendimento.

Cabe ressaltar, oportunamente, que o Código Civil, ao tratar da empreitada, prevê que o dono da obra não pode modificar projeto sem anuência do autor, a não ser que se demonstre a necessidade, por motivos supervenientes ou por razões de ordem técnica, ou se trate de modificação de pouca monta, ressalvada a unidade estética da obra projetada ${ }^{532}$.

Marco Aurelio S. Viana ${ }^{533}$ cita que a construtora que inclui no contrato a vaga de garagem, cobrando o seu preço, mas não entrega, responde pelos prejuízos causados, ainda que os condôminos tenham recebido a obra.

\footnotetext{
${ }^{531}$ Não obstante haver diferenciação, no âmbito da doutrina atrelada ao Código de Defesa do Consumidor, quanto a vícios e a defeitos, ressaltando-se que estes são muito mais graves e atingem mais que a utilidade ou valoração do bem. Ainda, cabe mencionar que o parágrafo $1^{\circ}$ do art. 12 do Código de Defesa do Consumidor define como defeituoso o produto que não oferece a segurança que dele se legitimamente espera.

${ }^{532}$ Nos termos do art. 612, a seguir: "Sem anuência de seu autor, não pode o proprietário da obra introduzir modificações no projeto por ele aprovado, ainda que a execução seja confiada a terceiros, a não ser que, por motivos supervenientes ou razões de ordem técnica, fique comprovada a inconveniência ou a excessiva onerosidade de execução do projeto em sua forma originária. Parágrafo único. A proibição deste artigo não abrange alterações de pouca monta, ressalvada sempre a unidade estética da obra projetada."

${ }^{533}$ VIANA, Marco Aurélio da Silva. Vagas de garagem na propriedade horizontal: doutrina e jurisprudência. São Paulo: Saraiva, 1981. p. 88-90.
} 
A parte final do art. 43, IV, faz ressalva à alteração mediante autorização unânime dos interessados ou exigência legal.

A questão da autorização dos interessados merece discussão. De fato, o incorporador poderia se eximir de responsabilidade, afirmando que apenas seguiu determinação do próprio interessado. Entretanto, deve-se cogitar se o interessado no caso tem condição de avaliar a tecnicidade de eventual modificação aprovada.

Parece haver vulnerabilidade técnica dos adquirentes, o que pode comprometer a validade de sua decisão quanto a determinada modificação.

Cabe ressaltar que, nas contratações por administração, é válida a contratação, entre condomínio e condômino, de modificações por este solicitadas em sua unidade, desde que não prejudiquem unidade de outro condômino e não estejam em desacordo com o parecer técnico do construtor, conforme exposto no art. 61, c), da Lei no 4.591/64.

Assim, o construtor administrará a modificação, mas, seguindo as diretrizes do adquirente, não deve ser responsabilizado ${ }^{534}$, principalmente se a decisão for contrária a parecer técnico seu.

Tal afirmação é válida, contudo, se o construtor tiver feito a ressalva quanto a eventual violação ao parecer, sob pena de responder por culpa.

A responsabilidade indicada deve estar presente também se não se tratar de administração, mas de modificação aprovada pelos interessados, como acima citado.

Veja-se entendimento jurisprudencial no sentido de que não pode o incorporador utilizar procuração outorgada pelos adquirentes para modificar o projeto ${ }^{535}$.

\footnotetext{
${ }^{534}$ Ressalvado que, segundo Franco e Gondo, o sistema muito utilizado na Europa de personalização das unidades autônomas, entre nós denominado de "acabamento personalizado", é permitido pelo art. 61, c, da Lei $\mathrm{n}^{\circ}$ 4.591/64. Quando, nesse sentido, a mudança na unidade for realizada a mando do adquirente, o incorporador não responde pela alteração. FRANCO, João Nascimento; GONDO Nisske. Incorporações imobiliárias, cit., p. 128.

${ }^{535}$ Nos termos da ementa: "PROCESSUAL CIVIL - LITISCONSÓRCIO FACULTATIVO CONDÔMINO. INCORPORADOR - PROJETO - ALTERAÇÃO - CONTRATO - CLÁUSULA PADRÃO DE MANDATO. I - Se o comunheiro de imóvel tem legitimidade para reivindicá-lo de terceiro, sem anuência dos demais condôminos, com maior razão pode pleitear indenização por danos à coisa comum ou postular que seja protegido preventivamente de eventuais danos. Direito que se insere na faculdade conferida aos co-proprietários. II - O litisconsórcio facultativo depende da vontade do demandado, porquanto, segundo a legislação pátria, não é dado constranger alguém a demandar. III - É vedado ao incorporador alterar o projeto ou desviar-se do plano da construção, salvo autorização unânime dos interessados ou exigência legal. IV - É defeso ao incorporador utilizar procuração outorgada pelos adquirentes de unidades incorporadas, para alterar, em detrimento deste, o plano da incorporação. Permitir lesão semelhante seria admitir que o mandatário atraiçoe o mandante." (REsp 586684/RJ, Terceira Turma, STJ, Rel. Min. Humberto Gomes de Barros, julg. em 01.06.04)
} 
No tocante a alteração por exigência legal, cabe esclarecer que é prevista em contrato, geralmente, a permissão de alterar o projeto de execução e o memorial em virtude de determinação ou exigência dos poderes públicos, do Corpo de Bombeiros ou de empresas concessionárias de serviços públicos, supervenientes à data deste contrato, o que não se faz exigível, uma vez que, havendo determinação de autoridade, a alteração se impõe, prescindindo de aprovação pelos adquirentes.

Ainda, prevê-se geralmente que na hipótese de falta de materiais no mercado, o incorporador pode substituir equipamentos ou acabamentos mencionados no memorial descritivo, desde que se mantenha o mesmo padrão dos substituídos e do empreendimento, no geral.

Considerando que o incorporador deve observar os projetos técnicos e o alvará de construção concedido, este deve responder se assim não o fizer, ficando sujeito às sanções administrativas, como de interdição e demolição de obra.

Contudo, segundo Cambler, a Administração Pública deve responder solidariamente com o incorporador perante os adquirentes na hipótese de anulação de alvará, bem como na hipótese de concessão de forma indevida de licenças para construir e habitar e de não concessão quando houver direito do requisitante ${ }^{536}$.

Com razão, uma vez que se trata de descumprimento relativo a obrigações dos agentes públicos enquanto representantes da Administração Pública. Nesse sentido, a apuração de sua responsabilidade segue regramento próprio, não objeto deste estudo.

Deve-se considerar, de forma geral, a obrigação de resultado do incorporador e o conteúdo legal que se volta à determinação de entrega do imóvel tal como prometido pelo incorporador, de forma que não se admitirá alteração no projeto, especialmente aquelas que venham a ferir direito de propriedade do adquirente.

Podemos citar, pois, que a coisa entregue não conterá todos os elementos previstos, se houver alteração significativa, devendo-se afastar, como exposto, alteração de material que não afete a qualidade e o padrão da obra.

Ressalte-se que a regulação de vício redibitório do Código Civil, por sua limitação, pode não ser aplicada ao caso, de forma que o adquirente pode se valer dos

\footnotetext{
${ }^{536}$ Entendimento esposado por CAMBLER, Everaldo Augusto. Incorporação imobiliária: ensaio de uma teoria geral, cit., p. 251 e ss.
} 
conceitos gerais das obrigações, para caracterizar o descumprimento de obrigação pelo incorporador (ou o mau cumprimento), e, portanto, sua responsabilidade contratual.

Havendo relação de consumo caracterizada, não se discute a proteção, nesse caso, do consumidor, valendo-se este dos preceitos gerais do Código de Defesa do Consumidor, que abarcam a tese da qualidade dos bens e serviços comercializados e a garantia legal correspondente $^{537}$, sem se olvidar da regra que define que a oferta de produtos e serviços obriga o fornecedor.

\subsubsection{Diferença de área}

Serão analisadas neste item as hipóteses relativas a compra e venda "ad corpus" e "ad mensuram" e a falta de área verificada, reclamação esta corriqueira na incorporação imobiliária $^{538}$.

O Código Civil Francês de 1804 (Código de Napoleão) já previa as consequências da falta de quantidade na compra e venda, fazendo distinção entre coisas vendidas como um todo ou por medida, apesar de não constar especificamente as nomenclaturas ad mensuram e ad corpus.

A compra e venda ad mensuram pode ser definida como aquela em que é essencial a correspondência entre a área ou dimensões declaradas pelas partes na contratação e a área e dimensões do imóvel efetivamente existentes. A ad corpus, ou de corpo certo, é aquela em que as partes negociam um objeto imóvel como coisa certa, sendo as medidas declaradas menos relevantes, ou melhor, não sendo essas essenciais para a negociação, uma vez que a venda foca o corpus e não medida ou extensão.

\footnotetext{
${ }^{537}$ Conforme CAVALIERI FILHO, Sergio. Programa de responsabilidade civil, cit., p. 361, a responsabilidade decorre da falta de conformidade ou qualidade da coisa ou serviço com a sua perspectiva de durabilidade e utilidade.

${ }^{538}$ Há entendimentos de que os vícios redibitórios não abrangem os vícios de quantidade, afastando, pois, casos de falta de quantidade ou de diferença encontrada na medida da coisa. Destacamos a citação feita por José Carlos Moreira Alves de que a diferença de área não é exemplo de caso de vício redibitório, pois se baseia na existência de um delito em determinada época do Direito Romano, em Direito romano, cit., v. 2, p. 187 e ss. Igualmente, MONTEIRO DE BARROS, Washington. Curso de direito civil: direito das obrigações, cit., v. 5, 2 pt., p. 49. Por outro lado, Scartezzini entende que tanto o vício de quantidade quanto o de qualidade são espécies do mesmo gênero (cumprimento imperfeito). GUIMARÃES, Paulo Jorge Scartezzini. Vícios do produto e do serviço por qualidade, quantidade e insegurança: cumprimento imperfeito do contrato, cit., p. 169.
} 
Limongi França ${ }^{539}$ conceitua a venda ad corpus como "aquela em que o objeto é referido como coisa certa e discriminada, sendo apenas enunciativa, se houver, a referência às suas dimensões".

A distinção é importante pois, no caso da compra e venda ad mensuram, se as dimensões reais não corresponderem às indicadas no ato contratual, o comprador terá direito de exigir o complemento da área ou medida ou, não sendo isto possível, reclamar abatimento de preço ou resolver o contrato.

Álvaro Villaça Azevedo ${ }^{540}$ explana que o preço, na compra e venda, serve para medir o valor da coisa comprada, sendo um correspectivo dos contratos onerosos, e que, em se tratando de contrato comutativo, há presunção da equivalência das prestações, não podendo, pois, o preço destoar, valorativamente, do objeto vendido.

Nas compras e vendas ad mensuram eventual desconformidade é, em regra, causa de interferência no negócio jurídico, uma vez que a parte afetada pode, de acordo com as regras de cada legislação, compelir a outra parte a determinados atos de forma a preservar ou assegurar a equivalência entre preço pago e coisa entregue.

$\mathrm{O}$ art. 500 do código Civil $^{541}$ trata da diferenciação entre venda ad corpus e ad mensuram.

O caput do artigo refere-se à compra e venda ad mensuram e ao direito ofertado ao comprador na hipótese de diferença de área.

\footnotetext{
${ }^{539}$ FRANÇA, Rubens Limongi. Jurisprudência da compra e venda. São Paulo: Ed. Revista dos Tribunais, 1983. p. 82. (Coleção RT - Jurisprudência, v. 14).

${ }^{540}$ AZEVEDO, Álvaro Villaça. Comentários ao novo Código Civil: das várias espécies de contrato: arts. 481 a 532. Coord. Sálvio de Figueiredo Teixeira. Rio de Janeiro: Forense, 2005. v. 2, p. 22 e ss.

${ }^{541}$ Art. 500. Se, na venda de um imóvel, se estipular o preço por medida de extensão, ou se determinar a respectiva área, e esta não corresponder, em qualquer dos casos, às dimensões dadas, o comprador terá o direito de exigir o complemento da área, e, não sendo isso possível, o de reclamar a resolução do contrato ou abatimento proporcional ao preço.

$\S 1$ lo Presume-se que a referência às dimensões foi simplesmente enunciativa, quando a diferença encontrada não exceder de um vigésimo da área total enunciada, ressalvado ao comprador o direito de provar que, em tais circunstâncias, não teria realizado o negócio.

$\S 2$ o Se em vez de falta houver excesso, e o vendedor provar que tinha motivos para ignorar a medida exata da área vendida, caberá ao comprador, à sua escolha, completar o valor correspondente ao preço ou devolver o excesso.

§ 3 o Não haverá complemento de área, nem devolução de excesso, se o imóvel for vendido como coisa certa e discriminada, tendo sido apenas enunciativa a referência às suas dimensões, ainda que não conste, de modo expresso, ter sido a venda ad corpus.
} 
Apenas em caso de compra e venda ad mensuram, na qual as partes definem o negócio em razão da medida e da extensão da coisa, eventual diferença entre a área declarada e a real será relevante, sendo esta a dicção do artigo em comento.

Nas vendas ad mensuram, legitima-se o comprador a exigir o complemento da área, ou, não sendo isso possível, a reclamar a resolução do contrato ou abatimento proporcional do preço.

Tal permissão será factível desde que eventual diferença seja superior a um vigésimo da área declarada, em razão da presunção contida no parágrafo primeiro.

Referida presunção estava prevista no Código anterior também, havendo, porém, inovação no trecho final que determina que, não obstante a presunção, e sendo esta relativa, pode-se pretender a complementação da área ou demais opções, se aquela for impossível, desde que o comprador prove que, em tais circunstâncias, não teria realizado o negócio. Cabe, assim, prova de que, ainda que se presuma irrelevante a diferença de até 1/20 entre a área declarada e a real, esta é relevante para o comprador.

Assim, caberá ao comprador, nas vendas ad mensuram, o direito de ingressar com a actio ex empto, desde que a diferença seja superior a $5 \%$ ou, ainda que não seja, desde que o comprador prove que se soubesse da diferença não teria realizado o negócio, tendo em vista que a presunção criada por lei é iuris tantum.

Segundo Otavio Luiz Rodrigues Junior, a presunção é "cláusula de tolerância” para afastar do Judiciário assuntos de pouca relevância, sendo permitido ao comprador, entretanto, a prova de que se soubesse da divergência (no limite da vigésima parte) não teria realizado o negócio ${ }^{542}$.

No tocante à presunção prevista pelo legislador, o entendimento mais correto é só se aplica aos casos de venda "ad mensuram" "543 , tendo em vista que se a compra e venda for ad corpus, nenhuma diferença ensejará o direito dado por lei àqueles que formalizam negócio ad mensuram, posto que a compra e venda ad corpus, em sua essência, despreza qualquer medida ou extensão para configuração do preço devido.

\footnotetext{
${ }^{542}$ RODRIGUES JUNIOR, Otavio Luis. Código Civil comentado. Compra e venda. Troca. Contrato estimatório. Artigos 481 a 537. São Paulo: Atlas, 2008. p. 243. (Coord. Álvaro Villaça Azevedo, v. 6).

${ }^{543}$ Conforme esposado no julgamento do REsp 618.824 pela Quarta Turma do STJ, em 01.12.09, conforme trecho da ementa a seguir: “(...) 3. Ademais, a presunção contida no § único, do art. 1.136/CC16, de que a referência à área de imóvel vendido é meramente enunciativa se a discrepância não ultrapassar 5\%, não conduz à conclusão, a contrario sensu, de que se ultrapassado esse percentual, tratar-se-ia de venda ad mensuram."
} 
Se as partes acordam a compra e venda de coisa específica e certa, sem preocupação com sua extensão, eventual diferença, superior ou inferior a um vigésimo, é irrelevante.

Saliente-se posicionamento de Limongi França ${ }^{544}$ no sentido de que é possível que as partes definam menor percentual para compreender a presunção, caso se trate de venda ad mensuram, não sendo pertinente, de qualquer forma, o acordo entre as partes em relação à alteração do percentual da presunção legal se se tratar de venda ad corpus, pois, nesta, qualquer diferença é aceitável.

Na compra e venda ad corpus, a área ou a extensão do imóvel, a priori, não é considerada relevante para as partes, que pretendem vender e comprar, respectivamente, coisa certa e conhecida.

A diferença superior a 5\%, desse modo, não tem o condão de determinar a espécie da compra e venda. É a espécie de compra e venda que vai determinar se a diferença é relevante ou não para o negócio jurídico.

Deve-se avaliar o contrato celebrado entre as partes, para análise da vontade das partes, sendo conceito doutrinário ${ }^{545}$ que algumas características do negócio podem indicar a venda ad corpus, como o uso da expressão "mais ou menos", "cerca de" ou "aproximadamente" para se qualificar a extensão da coisa, ou o fato de ser o imóvel cercado ou murado, especialmente em zona urbana, ou mesmo quando a escritura nomeia ou especifica os imóveis confinantes, o que é claramente visto na maior parte das regiões de maior concentração geográfica.

Dessa forma, o direito mencionado no art. 500, que se exerce pela ação ex empto, só é aplicável a vendas ad mensuram, devendo tal compreensão ser exercida previamente à análise da aplicação ou não do caput do artigo mencionado. Havendo dúvidas, haverá de se verificar o contrato ${ }^{546}$, a vontade das partes, entre outras formas de prova, para se conceituar o negócio em análise como ad mensuram ou ad corpus.

\footnotetext{
${ }^{544}$ FRANÇA, Rubens Limongi. Jurisprudência da compra e venda, cit., p. 83.

${ }^{545}$ Como o de SIMÃO, José Fernando. Prescrição e decadência: início dos prazos. São Paulo: Atlas, 2013. p. 251.

${ }^{546}$ Nesse sentido, trata-se de questão fática, como revela trecho da ementa do acórdão do $\mathrm{AgRg}$ no $\mathrm{Ag}$ 1357425 / SC, julgado pela Terceira Turma do STJ, em 05.04.11: “(...) 2. A verificação da intenção das partes quanto a natureza "ad corpus" ou "ad mensuram" da contratação exige o reexame do contexto fático probatório e da interpretação das cláusulas contratuais...".
} 
Verificando-se se tratar de compra e venda ad corpus, caso se confira diferença de mais ou de menos 5\% na área do imóvel adquirido, serão descabidas as pretensões ofertadas ao comprador pelo art. 500 do Código Civil atual, assim como também as serão na hipótese de se tratar de compra ad mensuram, caso a diferença seja de até 1/20 da extensão total $^{547}$.

Diante de venda ad mensuram, com diferença superior à presunção do legislador, cabem os remédios previstos em lei, a critério do comprador: a complementação de área, e, não sendo possível, a resolução do contrato ou o abatimento proporcional ao preço.

Nos termos do ensinamento de Otavio Rodrigues ${ }^{548}$, a permissão de propositura de ação única é adequada, de forma que se pleiteiem sucessivamente os pedidos cabíveis, evitando-se o problema que estava escondido no Código anterior, em razão da definição do prazo prescricional vintenário para propositura da ação ex empto.

Assim, para não prejudicar o interessado, deve-se admitir a cumulação de pedidos, de forma que, se não possível a complementação, o autor, nos mesmos autos, obtenha a tutela desejada.

Em relação à complementação da área, cabe verificar se será útil, de forma que não haja prejuízo ao comprador e que o imóvel não perca sua finalidade.

Grande inovação do Código Civil de 2002 foi a permissão ao vendedor de ingressar com a competente ação ante o excesso de área vendida, não se autorizando, contudo, que a escolha fique a critério do vendedor, sendo que, nessa hipótese, cabe ao comprador a escolha entre complementar o preço ou devolver o excesso, não havendo, pois, possibilidade de resolução do contrato.

Pode-se afirmar que se trata de boa escolha do legislador, uma vez que preserva o negócio e o interesse do comprador, ao mesmo tempo em que realiza justiça, aos olhos do

\footnotetext{
${ }^{547}$ Verifica-se que o legislador italiano previu expressamente hipótese de diferença de até 1/20 em caso de aquisição de imóvel a construir, referindo-se, entretanto, a superfície e à quota, conforme art. 2645 bis paragrafo 5: "5. Nel caso previsto nel comma 4 la trascrizione è eseguita con riferimento al bene immobile per la quota determinata secondo le modalità di cui al comma stesso. Non appena l'edificio viene ad esistenza gli effetti della trascrizione si producono rispetto alle porzioni materiali corrispondenti alle quote di proprietà predeterminate nonché alle relative parti comuni. L'eventuale differenza di superficie o di quota contenuta nei limiti di un ventesimo rispetto a quelle indicate nel contratto preliminare non produce effetti.”. Qualquer diferença de superfície ou porção contida dentro dos limites de um vigésimo comparado àqueles mostrados no contrato preliminar tem nenhum efeito.

${ }^{548}$ RODRIGUES JUNIOR, Otavio Luis. Código Civil comentado. Compra e venda. Troca. Contrato estimatório. Artigos 481 a 537, cit., p. 263.
} 
vendedor, desde que este venha a comprovar que tinha razões para ignorar a medida real da área vendida, nos termos do parágrafo segundo do art. 500 .

No tocante ao prazo para propositura das ações previstas no art. 500, faz-se necessária a análise do artigo $501^{549}$.

Em razão da sistematização da prescrição e da decadência, já mencionada, pela literalidade do art. 501, trata-se de prazo de decadência, apesar de mencionar, equivocadamente, que há decadência quanto ao direito de propor a ação, o que se refere, como sabido, à prescrição.

Assim, afirma-se que o prazo decadencial para ações ex empto é de um ano a contar do registro do título, ou, no caso de atraso na imissão da posse atribuível ao vendedor, quando isso acontecer efetivamente.

O prazo para propositura da ação ex empto e das edilícias, quando se trata de imóvel, é, portanto, o mesmo, ou seja, de um ano.

Outra análise que deve ser feita é em relação ao início do prazo e forma de contagem. Parece inadequado vincular o início do prazo a ato formal translativo de propriedade, quando a verificação quanto a eventual diferença faz-se, via de regra, na esfera prática e factual, sendo certo que o negócio da venda é amparado pelos documentos atinentes ao imóvel, inclusive matrícula correspondente.

Ademais, a prática indica que muitas vezes o registro não é feito ou é feito muito tempo depois, sendo que vincular a contagem do prazo a uma data que pode ser 1,5 ou 10 anos após a efetiva imissão na posse traria muita insegurança no campo jurídico e aos negócios de compra e venda.

Assim, o prazo deve ser contado da imissão na posse pelo comprador.

Ressalte-se, no entanto, que o legislador preferiu trazer como exceção a questão da imissão na posse, de forma a não prejudicar o comprador que, por fato imputável ao vendedor, não pode imitir-se na posse do imóvel.

\footnotetext{
549“"Art. 501. Decai do direito de propor as ações previstas no artigo antecedente o vendedor ou o comprador que não o fizer no prazo de um ano, a contar do registro do título.

Parágrafo único. Se houver atraso na imissão de posse no imóvel, atribuível ao alienante, a partir dela fluirá o prazo de decadência.".
} 
Verifica-se que a aplicação do art. 500 não interfere no direito de retificação de registro, como definido em acórdão referente ao julgamento, pela Primeira Câmara Cível do Tribunal de Justiça do Estado de Minas Gerais, da Apelação Cível $\mathrm{n}^{\circ}$ 1.0382.03.027948-5/001 $1^{550}$.

Apresentadas as principais discussões acerca da compra e venda ad corpus e ad mensuram, cabe verificar entendimento de que tais conceitos são aplicáveis à incorporação imobiliária:

[...] Não é possível a condenação de construtora ao pagamento de indenização na hipótese em que a diferença de metragem entre a área do imóvel entregue e a área estabelecida em contrato de compra e venda firmado na vigência do Código Civil de 1916 é inferior a um vigésimo da extensão total enunciada no referido contrato, pois, ainda que se trate de imóvel situado em condomínio vertical, regido pela Lei 4.591/1964, aplica-se a norma prevista no parágrafo único do art. 1.136 do CC/1916, visto que não há na Lei 4.591/1964 qualquer norma de conteúdo incompatível com o Código Civil anterior."(grifos da autora)

(REsp 326125 / DF, Quarta Turma, STJ, Rel. Min. Maria Isabel Gallotti julg. em 04.10.11)

Com razão, a Lei $n^{\circ} 4.591 / 64$ de fato não prevê condições específicas quanto à verificação de diferença de área, ainda que se trate de hipótese de entrega de coisa em violação ao projeto constante do memorial de incorporação, afetando, pois, a obrigação de entrega do imóvel pelo incorporador.

Entretanto, dificilmente o imóvel, na incorporação imobiliária, será vendido por medida. O mais usual é a venda como coisa certa.

Dessa forma, poder-se-ia afirmar, inicialmente, que as regras previstas no Código Civil não são aplicáveis à incorporação imobiliária.

Apesar disso, não se pode afastar o direito do adquirente na incorporação imobiliária de obter remédio apropriado em caso de entrega do imóvel sem a dimensão ofertada pelo incorporador, ainda que se trate de venda considerada ad corpus.

\footnotetext{
${ }^{550}$ Como se verifica do trecho a seguir transposto: “(...) Se a dimensão, apenas enunciativa, não corresponder à área, aplica-se o $\S 3^{\circ}$ do art. 500, que dispõe que "Não haverá complemento de área, nem devolução de excesso, se o imóvel for vendido como coisa certa e discriminada, tendo sido apenas enunciativa a referência às suas dimensões, ainda que não conste, de modo expresso, ter sido a venda 'ad corpus'. Poderá haver, porém, a simples retificação do registro (e não da área), hipótese que se enquadra nos arts. 212 e 213 da Lei 6.015/73(...).”
} 
Dessa forma, impõe-se a aplicação da tese de cumprimento inadequado da obrigação de entregar a unidade tal como prometida e de acordo com o projeto e descrição das unidades autônomas, como prevê a Lei $n^{\circ} 4.591 / 64$, e/ou a tese consumerista de existência de vício do produto ou serviço, se configurada relação de consumo.

Quanto à regulação prevista no Código de Defesa do Consumidor no tocante a vícios, reporta-se ao item 4.1.4.1.2 deste estudo. Tal Código, em seu art. 1951, prevê especificamente a responsabilidade em caso de vício de quantidade de produto, cabendo ao consumidor a escolha entre o abatimento do preço, a complementação da medida, a substituição do bem ou a resolução do contrato, remédios similares aos constantes do Código Civil, havendo entendimento de que, ao se aplicar o Código de Defesa do Consumidor, mesmo na hipótese de venda de coisa por corpo, deve-se assegurar remédio protetivo aos adquirentes, por se tratar de vício de quantidade, disparidade entre oferta e a prestação efetivamente entregue ${ }^{552}$.

A substituição do bem é medida demasiadamente complicada quando se trata de imóvel, sendo mais razoável, na incorporação imobiliária, a escolha entre o abatimento de valor ou a resolução contratual.

Veja-se que o direito francês é menos limitante em relação a essa matéria: os arts. 1.616 e $1.617^{553}$ definem que o vendedor deve entregar o bem com as medidas especificadas no contrato, se houver indicação de tais medidas, e, caso não seja possível, o vendedor fica obrigado a reduzir o preço.

\footnotetext{
551“ Art. 19. Os fornecedores respondem solidariamente pelos vícios de quantidade do produto sempre que, respeitadas as variações decorrentes de sua natureza, seu conteúdo líquido for inferior às indicações constantes do recipiente, da embalagem, rotulagem ou de mensagem publicitária, podendo o consumidor exigir, alternativamente e à sua escolha: I - o abatimento proporcional do preço; II - complementação do peso ou medida; III - a substituição do produto por outro da mesma espécie, marca ou modelo, sem os aludidos vícios; IV - a restituição imediata da quantia paga, monetariamente atualizada, sem prejuízo de eventuais perdas e danos. $\S 1^{\circ}$ Aplica-se a este artigo o disposto no $\S 4^{\circ}$ do artigo anterior. (...)".

${ }^{552}$ RIZZATO NUNES, Luiz Antonio. Comentários ao Código de Defesa do Consumidor, cit., p. 278.

${ }^{553 ، L}$ "Le vendeur est tenu de délivrer la contenance telle qu'elle est portée au contrat, sous les modifications ciaprès exprimées." E "Si la vente d'un immeuble a été faite avec indication de la contenance, à raison de tant la mesure, le vendeur est obligé de délivrer à l'acquéreur, s'il l'exige, la quantité indiquée au contrat; Et si la chose ne lui est pas possible, ou si l'acquéreur ne l'exige pas, le vendeur est obligé de souffrir une diminution proportionnelle du prix.", respectivamente.
} 
$\mathrm{O}$ art. $1.618^{554}$ faz referência à entrega de bem como medida superior à prevista, devendo o comprador complementar o preço ou, caso a diferença seja superior a 5\%, optar pela resolução do contrato.

Ocorre que o art. 1.619, tratando das vendas ad corpus, prevê igualmente a presunção de que diferenças até $5 \%$ são aceitáveis, não cabendo ao adquirente ou ao vendedor, conforme o caso, qualquer ação ${ }^{555}$.

Em qualquer caso que tenha acão tanto o vendedor quanto o adquirente, aquela deve ser providenciada em um ano da data do contrato, sob pena de decadência ${ }^{556}$.

No direito espanhol, a regra é semelhante, conforme art. 1.471 do Código Civil ${ }^{557}$ : tratando-se a venda por coisa determinada, nenhuma diferença é coberta. Contudo, sendo a venda por dimensão ou quantidade, eventual diferença permitirá a cobrança da entrega do todo contratado ou, se essa não for possível, a redução do preço, exceto se o comprador não aceitar a ausência da entrega do todo, quando o contrato poderá ser anulado.

Para qualquer das ações há prazo de seis meses, nos termos do art. $1.472^{558}$.

Na Itália, as regras são similares, havendo indicação do único remédio para as vendas ad mensuram, que é o de redução de preço, podendo o comprador resolver o contrato, contudo, se a medida real for $5 \%$ maior que a especificada no contrato, pois, neste caso, pode-se entender que a complementação do preço é de grande monta.

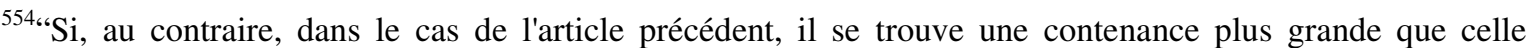
exprimée au contrat, l'acquéreur a le choix de fournir le supplément du prix, ou de se désister du contrat, si l'excédent est d'un vingtième au-dessus de la contenance déclarée."

${ }^{555}$ Art. 1619: "Dans tous les autres cas, soit qu'elle ait que la vente soit faite d'un corps certain et limité, Soit qu'elle ait pour objet des fonds distincts et séparés, Soit qu'elle commence par la mesure, ou par la désignation de l'objet vendu suivie de la mesure, L'expression de cette mesure ne donne lieu à aucun supplément de prix, en faveur du vendeur, pour l'excédent de mesure, ni en faveur de l'acquéreur, à aucune diminution du prix pour moindre mesure, qu'autant que la différence de la mesure réelle à celle exprimée au contrat est d'un vingtième en plus ou en moins, eu égard à la valeur de la totalité des objets vendus, s'il n'y a stipulation contraire.".

${ }^{556}$ Conforme art. 1622: "L'action en supplement de prix de la part du vendeur, et celle en diminution de prix ou en résiliation du contrat de la part de l'acquéreur, doivent être intentées dans l'année, à compter du jour du contrat, à peine de déchéance."

${ }^{557}$ Art. 1471- "En la venta de un inmueble, hecha por precio alzado y no a razón de un tanto por unidad de medida o número, no tendrá lugar el aumento o disminución del mismo, aunque resulte mayor o menor cabida o número de los expresados en el contrato. $\square$ Esto mismo tendrá lugar cuando sean dos o más fincas las vendidas por un solo precio; pero, si, además de expresarse los linderos, indispensables en toda enajenación de inmuebles, se designaren en el contrato su cabida o número, el vendedor estará obligado a entregar todo lo que se comprenda dentro de los mismos linderos, aun cuando exceda de la cabida o número expresados en el contrato; y, si no pudiere, sufrirá una disminución en el precio, proporcional a lo que falte de cabida o número, a no ser que el contrato quede anulado por no conformarse el comprador con que se deje de entregar lo que se estipuló.

558“Las acciones que nacen de los tres artículos anteriores prescribirán a los seis meses, contados desde el día de la entrega.".
} 
Especificamente quanto às vendas ad corpus, o legislador fez referência à diferença superior a 5\%, sendo que, sendo a coisa vendida por corpo, mas havendo diferença superior a esse montante, abre-se a oportunidade de escolha pelo comprador entre a resolução e eventual abatimento ou complementação de preço.

As ações previstas no Código Civil italiano devem ser exercidas no prazo de um ano, especificando-se que se trata de prazo prescricional $^{559}$.

\subsubsection{Responsabilidade pela solidez e segurança da obra}

Conforme Cavalieri, após a execução do contrato e entrega da obra tem início a parte mais relevante e grave da responsabilidade do incorporadorlconstrutor, que é a responsabilidade pela segurança e qualidade da obra ${ }^{560}$.

Tal responsabilidade está prevista nas normas inseridas no Código Civil, especialmente nos artigos $618^{561}$ e seguintes, que dispõem sobre a responsabilidade ${ }^{562}$ póscontratual dos empreiteiros de materiais e execução, nos contratos de empreitada de edifícios ou outras construções consideráveis, abrangendo a solidez e segurança do trabalho, em razão dos materiais como do solo.

\footnotetext{
559، Art. 1537- Vendita a misura. Quando un determinato immobile (812) è venduto con l'indicazione della sua misura e per un prezzo stabilito in ragione di un tanto per ogni unità di misura, il compratore ha diritto a una riduzione, se la misura effettiva dell'immobile è inferiore a quella indicata nel contratto (att. 166). Se la misura risulta superiore a quella indicata nel contratto, il compratore deve corrispondere il supplemento del prezzo, ma ha facoltà di recedere dal contratto qualora l'eccedenza oltrepassi la ventesima parte della misura dichiarata.”; “Art. 1538- Vendita a corpo. Nei casi in cui il prezzo è determinato in relazione al corpo dell'immobile e non alla sua misura, sebbene questa sia stata indicata, non si fa luogo a diminuzione o a supplemento di prezzo, salvo che la misura reale sia inferiore o superiore di un ventesimo rispetto a quella indicata nel contratto. Nel caso in cui dovrebbe pagarsi un supplemento di prezzo, il compratore ha la scelta di recedere dal contratto o di corrispondere il supplemento. "Art. 1539 - Recesso dal contrato. Quando il compratore esercita il diritto di recesso, il venditore è tenuto a restituire il prezzo e a rimborsare le spese del contratto (1475)"; (...); "Art. 1541 - Prescrizione. Il diritto del venditore al supplemento e quello del compratore alla diminuzione del prezzo o al recesso dal contratto si prescrivono in un anno dalla consegna dell'immobile (att. 178).”.

${ }^{560}$ CAVALIERI FILHO, Sergio. Programa de direito do consumidor, cit., p. 227.

561“Art. 618. Nos contratos de empreitada de edifícios ou outras construções consideráveis, o empreiteiro de materiais e execução responderá, durante o prazo irredutível de cinco anos, pela solidez e segurança do trabalho, assim em razão dos materiais, como do solo."

${ }^{562}$ Caio Mario, com razão, entende que se trata de responsabilidade sem culpa. PEREIRA, Caio Mário da Silva. Instituições de direito civil: contratos, cit., v. 3, p. 285.
} 
Responde também pela solidez e segurança do trabalho o autor do projeto utilizado para construção, nos termos do art. 622 do Código Civil ${ }^{563}$. Caso o autor assuma a direção ou fiscalização da obra, responsabilizar-se-á também por tal atuação.

Sem prejuízo da responsabilidade pós-contratual a ser analisada, ressaltamos que os riscos no contrato de empreitada de materiais e mão de obra correm para o empreiteiro até o momento da entrega da coisa ${ }^{564}$. Sendo assim, o construtor/incorporador responde integralmente pela obra nesse caso, exceto se o dono da obra estiver em mora, nos termos do art. 611 do Código Civil ${ }^{565}$.

Caso, contudo, o fornecimento seja só de mão de obra, só responde o empreiteiro naquilo que tiver culpa ${ }^{566}$.

Aguiar Dias defende, adequadamente, que a obrigação do empreiteiro de construções é de resultado, motivo pelo qual sua responsabilidade deriva da garantia de que a obra servirá ao destino para que foi encomendada ${ }^{567}$.

Pertinente analisar a abrangência do disposto no art. 618 do Código Civil, e se inclui, por exemplo, apenas casos de solidez e segurança.

Entende-se que o conceito deve afastar imperfeições de pequena monta, mas não se subsume a casos de risco de ruína da obra ${ }^{568}$.

Assim, qualquer defeito que venha a comprometer a obra como um todo, inclusive cada unidade, e possa gerar risco à edificação, aos adquirentes e a terceiros, ainda que não decorrente de ruína, deve ser abrangido, excluindo-se, contudo, vícios e defeitos menores

\footnotetext{
563،Art. 622. Se a execução da obra for confiada a terceiros, a responsabilidade do autor do projeto respectivo, desde que não assuma a direção ou fiscalização daquela, ficará limitada aos danos resultantes de defeitos previstos no art. 618 e seu parágrafo único."

${ }^{564}$ PEREIRA, Caio Mário da Silva. Instituições de direito civil: contratos, cit., v. 3, p. 287.

565،Art. 611. Quando o empreiteiro fornece os materiais, correm por sua conta os riscos até o momento da entrega da obra, a contento de quem a encomendou, se este não estiver em mora de receber. Mas se estiver, por sua conta correrão os riscos."

${ }^{566}$ Nos termos do art. 612: "Se o empreiteiro só forneceu mão-de-obra, todos os riscos em que não tiver culpa correrão por conta do dono.".

${ }^{567}$ AGUIAR DIAS, José de. Da responsabilidade civil, cit., p. 387.

${ }^{568}$ Nesse sentido, CAMBLER, Everaldo Augusto. Responsabilidade civil na incorporação imobiliária, cit., p. 273; CHALHUB, Melhim Namem. Da incorporação imobiliária, cit., p. 392. Veja-se, ainda, entendimento do STJ, que define que outros defeitos de menor gravidade ou monta que comprometam a habitabilidade do imóvel devem ser considerados: “(...) Por certo o dispositivo há de ser interpretado de forma mais ampla do que sugere a construção gramatical, de modo a abranger não apenas os defeitos que possam ocasionar a ruína da edificação, mas também aqueles outros que, nada obstante de menor gravidade, possam, ainda assim, comprometer a habitabilidade do imóvel. (Recurso Especial nº 1.172.331, Terceira Turma, Rel. Min. João Otávio de Noronha, julg. em 24.09.13).
} 
que não comprometem a edificação nem a habitabilidade, mas possam ser inconvenientes e diminuir o valor do bem.

O direito italiano parece abarcar muitas hipóteses que, ainda que não se refiram especificamente a instabilidade da construção ou risco de seu colapso, podem ensejar diminuição sensível do valor econômico do edifício, como um todo, e da unidade autônoma, abrangendo, como grave defeito, uso de materiais impróprios ou não recomendáveis pela arte e erros de projeto, bem como defeitos relacionados a impermeabilização, umidade, destaque de gesso da construção, defeito no sistema de aquecimento do edifício, inadequação da rede de esgoto etc ${ }^{569}$.

Lorenzo Mezzasoma explana que, ainda que o art. 1.669 do Código Civil italiano preveja aplicação para vícios de "maggiore gravita", o art. $4^{\circ}$ do Decreto-Lei no 122/05 menciona somente "vizi e difformita", tendo o legislador expressamente previsto que os prejuízos devem ser relacionados a vício do solo ou defeito de construção ${ }^{570}$.

O direito francês tem previsão semelhante, nos arts. 1.792 e seguintes do Código Civil $^{571}$, definindo-se que o empreiteiro é automaticamente responsável por vícios ou defeitos, mesmo que por vício no solo, que afetem a solidez da obra ou um dos elementos da edificação, tornando-a imprópria para a sua finalidade.

Quanto ao prazo previsto no parágrafo único do art. 618, deve-se avaliar sua natureza.

Em razão da diversidade de julgados, houve edição da Súmula 194 pelo Superior Tribunal de Justiça, em 1997, que indicava que o prazo para ação de indenização pelos defeitos da obra era de vinte anos, de forma que o prazo de cinco anos não significava prescrição, mas sim garantia.

\footnotetext{
${ }^{569}$ Conforme TRIOLA, Roberto. Vendita di immobili da costruire e tutela dell'acquirente, cit., p. 180 e ss.

${ }^{570}$ MEZZASOMA, Lorenzo. Il "Consumatore" acquirente di immobili da costruire fra diritto al risparmio $e$ diritto all'abitazione, cit., p. 193-194.

${ }^{571} \mathrm{O}$ art. 1.792 tem a seguinte redação: "Tout constructeur d'un ouvrage est responsable de plein droit, envers le maître ou l'acquéreur de l'ouvrage, des dommages, même résultant d'un vice du sol, qui compromettent la solidité de l'ouvrage ou qui, l'affectant dans l'un de ses éléments constitutifs ou l'un de ses éléments d'équipement, le rendent impropre à sa destination.

Une telle responsabilité n'a point lieu si le constructeur prouve que les dommages proviennent d'une cause étrangère."
} 
Com o advento do Código Civil de 2002, passou-se a discutir o prazo aplicável. Chalhub entende se tratar, atualmente, do prazo de dez anos, por ser o maior prazo previsto no Código vigente ${ }^{572}$.

Em 2004, foi editado o Enunciado $\mathrm{n}^{\circ} 181$ da III Jornada de Direito Civil do Conselho da Justiça Federal: “Art. 618: O prazo referido no art. 618, parágrafo único, do Código Civil refere-se unicamente à garantia prevista no caput, sem prejuízo de poder o dono da obra, com base no mau cumprimento do contrato de empreitada, demandar perdas e danos.".

Pela literalidade do artigo 618, entende-se que o prazo de cinco anos é de garantia, e, desde que surgido vício ou defeito neste prazo, deve haver a propositura de ação contra o empreiteiro em cento e oitenta dias, não sendo necessária a busca por nenhum outro $\operatorname{prazo}^{573}$.

Admitindo-se que o disposto em referido artigo é dispositivo, as partes poderiam reduzir ou aumentar o prazo ali previsto; acolhendo-se, contudo, a tese de que se trata de garantia legal, seria inconcebível a exoneração do responsável ou a diminuição do prazo.

O prazo tratado no art. 618 do Código Civil, como expressamente ali previsto, é irredutível, não podendo ser diminuído ou suprimido, sendo, assim, obrigação legal prevista em nosso ordenamento para proteção da sociedade em relação a riscos altíssimos, que por sua magnitude ensejam a proteção efetiva do legislador.

O legislador francês optou por definir expressamente a impossibilidade de limitação ou exclusão dessa garantia, sendo nula qualquer cláusula que assim pretender $^{574}$.

O Código Civil italiano prevê, em seu art. 1.669, o prazo de dez anos em relação à responsabilidade do construtor/empreiteiro, pela ruína ou defeitos da construção, como garantia de solidez da obra.

\footnotetext{
${ }^{572}$ CHALHUB, Melhim Namem. Da incorporação imobiliária, cit., p. 391.

${ }^{573}$ De forma contrária, e com base no Enunciado 181, entende-se que para reparação de danos, dever-se-ia seguir outro prazo prescricional, podendo ser de 3 anos do art. 206, parágrafo $3^{\circ}$, V; o de 5 anos, do CDC, e o de 10 anos do art. 205, caput, na lição de SIMÃO, José Fernando. Prescrição e decadência: início dos prazos, cit., p. 270.

${ }^{574}$ Nos termos do art. 1794-5: "Tout clause d'un contrat qui a pour objet, soit d'exclure ou de limiter la responsabilité prévue aux articles 1792,1792-1 et 1792-2, soit d'exclure les garanties prévues aux Articles 1792-3 et 1792-6 ou d'en limiter la portée, soit d'écarter ou de limiter la solidarité prévue à l'article 1792-4, est réputée non écrite.".
} 
Segundo Triola, a jurisprudência italiana entende que tal responsabilidade é extracontratual $^{575}$ e de ordem pública, aplicando-se também para o vendedor que utilize trabalho de terceiro, mas mantenha a gerência do projeto, como é o caso do incorporador $^{576}$.

Cabe ressaltar, ainda, que o art. 2.053 do Código Civil italiano prevê a responsabilidade do dono de edifício ou outra construção por danos causados por sua ruína, exceto se provar que os danos decorrem de defeito de manutenção ou vício de construção, hipótese em que caberá direito de regresso contra os verdadeiros responsáveis ${ }^{577}$.

Para reforçar a responsabilidade pela solidez da construção, no âmbito da venda de imóveis em construção na Itália, o Decreto-Lei n 122/05 prevê que o incorporador contrate seguro que assegure indenização em caso de danos decorrentes de vícios graves de construção.

Há presunção de culpa no procedimento técnico da construção se houver ruína em edificação no prazo de dez anos, sendo tal prazo contado do término da obra, que, para fins da venda de imóvel em construção, é considerado o momento de obtenção do "certificato di agibilità, ${ }^{578}$.

Veja-se que a solução italiana diverge quanto ao prazo, sendo o prazo de dez anos considerado como de garantia, havendo, ainda, prazo decadencial de um ano para o interessado denunciar a existência de ruína ao responsável, e, após tal denúncia, prazo prescricional de mais um ano para ingressar com a ação judicial visando a indenização ${ }^{579}$.

Não obstante, critica-se o conteúdo do Decreto-Lei $n^{\circ} 122 / 05$, por não prever sanção pelo descumprimento de contratação do seguro acima mencionado, cabendo ao

\footnotetext{
${ }^{575} \mathrm{De}$ forma que qualquer terceiro prejudicado pode fazer valer a garantia, conforme informa Lorenzo Mezzasoma, Il "Consumatore" acquirente di immobili da costruire fra diritto al risparmio e diritto all'abitazione, cit., p. 197.

${ }^{576}$ TRIOLA, Roberto. Vendita di immobili da costruire e tutela dell'acquirente, cit., p. 178 e ss. Referido autor prossegue, ainda, defendendo a aplicação do art. 2.058 do Código Civil italiano para permitir ao adquirente ação que vise a eliminação do vício: “....possano essere chiesti dal compratore il risarcimento in forma specifica del danno patito e, quindi, la condanna del venditore ad eseguire le opere necessarie per l'eliminazione dei riscontrati difetti costruttivi."

577، “Art. 2053 - Il proprietario di un edificio o di altra costruzione è responsabile dei danni cagionati dalla loro rovina, salvo che provi che questa non è dovuta a difetto di manutenzione o a vizio di costruzione.".

${ }^{578}$ MEZZASOMA, Lorenzo. Il "Consumatore" acquirente di immobili da costruire fra diritto al risparmio e diritto all'abitazione, cit., p. 201.

${ }^{579}$ Desrespeitado qualquer dos três prazos, a indenização resta prejudicada, segundo Lorenzo Mezzasoma, Il "Consumatore" acquirente di immobili da costruire fra diritto al risparmio e diritto all'abitazione, cit., p. 202.
} 
adquirente, em sua ausência, os remédios regulares voltados à resolução contratual ou ao ressarcimento de danos advindos do descumprimento de tal obrigação ${ }^{580}$.

A solução francesa é semelhante, no sentido de prever presunção de responsabilidade na hipótese de surgimento, no período decenal, de vícios que afetem a solidez da edificação ou seu uso para os fins a que se destina ${ }^{581}$.

Trata-se, igualmente, de garantia de ordem pública $^{582}$, de forma que não pode haver redução ou exoneração de tal responsabilidade por meio de contrato.

O construtor, assim como outras pessoas a ele equiparadas, responde pelos vícios ocultos que surgirem nesse período, contado a partir da data de entrega, ainda que provisória.

O art. 1.646-1 do Código Civil francês, inserido pela Lei nº 67-3 de 1967, define que o vendedor de edifício a ser construído responderá pelas obrigações de terceiros, incluindo arquitetos, empreiteiros e outras pessoas ligadas ao dono da obra, inclusive as obrigações decorrentes do art. 1.792 acima citado, de forma que, então, o incorporador passa a responder pela solidez da obra ${ }^{583}$.

É previsto no art. 242-1 do Code de la construction et de l'habitation a obrigação de qualquer pessoa que for responsável nos termos dos artigos 1.792 e seguintes acima citados prover seguro para assegurar o pagamento de todos os reparos cabíveis, havendo prazos específicos em lei para que haja a cobertura do seguro ${ }^{584}$.

\footnotetext{
${ }^{580}$ Conforme MEZZASOMA, Lorenzo. Il "Consumatore" acquirente di immobili da costruire fra diritto al risparmio e diritto all'abitazione, cit., p. 210-212.

${ }^{581}$ Segundo dicção do art. 1.792, já citado, e do 2.270-2 do Código Civil francês, que assim dispõe: "Les architectes, entrepreneurs et autres personnes liées au maître de l'ouvrage par un contrat de louage d'ouvrage sont déchargés de la garantie des ouvrages qu'ils ont faits ou dirigés après dix ans s'il s'agit de gros ouvrages, après deux ans pour les menus ouvrages.". O art. 111-19 do Code de la construction et de l'habitation tem a seguinte redação: "Les actions en responsabilité dirigées contre un sous-traitant en raison de dommages affectant un ouvrage ou des éléments d'équipement d'un ouvrage mentionnés aux articles 1792 et 1792-2 du code civil se prescrivent par dix ans à compter de la réception des travaux et, pour les dommages affectant ceux des éléments d'équipement de l'ouvrage mentionnés à l'article 1792-3 du code civil, par deux ans à compter de cette même réception.".

${ }^{582}$ LUCHEUX, Jean-Michel. Les garanties de l'acquéreur dans les ventes d'immeubles à construire, cit., p. 136.

${ }^{583} \mathrm{O}$ que, em nosso entendimento, não seria necessário, uma vez que o paragráfo 2 do art.1792-1 define que é equiparado a construtor aquele que vende, antes de sua conclusão, obra a ser construída ou em construção: "Est réputé constructeur de l'ouvrage : (...) $2^{\circ}$ Toute personne qui vend, après achèvement, un ouvrage qu'elle a construit ou fait construire ;".

584“"Art. L. 242-1-Toute personne physique ou morale qui, agissant en qualité de propriétaire de l'ouvrage, de vendeur ou de mandataire du propriétaire de l'ouvrage, fait réaliser des travaux de construction, doit souscrire avant l'ouverture du chantier, pour son compte ou pour celui des propriétaires successifs, une assurance garantissant, en dehors de toute recherche des responsabilités, le paiement de la totalité des travaux de réparation des dommages de la nature de ceux dont sont responsables les constructeurs au sens
} 
Havendo obrigação do vendedor de reparar o dano, o artigo 1.646-1 define que não será necessária a resolução do contrato ou a redução de preço.

No direito espanhol, há controvérsia em relação ao regramento aplicável em hipóteses atinentes a solidez da obra, em razão da edição da Ley de Ordenacion de Edificación.

O art. 1.591 do Código Civil espanhol ${ }^{585}$ define que, para haver responsabilidade do empreiteiro/construtor, a ruína do prédio deve acontecer em dez anos, contados da conclusão da construção. Se a ruína for decorrente de vício do solo ou da má direção da obra pelo arquiteto encarregado, haverá responsabilidade desse.

Segundo o mesmo artigo 1.591, a ação de indenização terá prazo prescricional de quinze anos se o construtor deixar de observar as condições do contrato.

Ocorre que a Ley de Ordenacion de Edificacion prevê, em seu art. $17,{ }^{586}$ três prazos diferentes de garantia voltada aos danos materiais à edificação, conforme a gravidade do vício, sendo de dez anos para danos decorrentes de defeitos que afetem a sua estrutura; de três anos para danos decorrentes de vícios que gerem descumprimento de requisitos de habitabilidade; e de um ano para vícios que afetem o acabamento da obra.

Aludido artigo define a solidariedade do promotor com os demais agentes: “(...)hace referencia a la responsabilidade del promotor en la ejecucion de la obra,

de l'article 1792-1, les fabricants et importateurs ou le contrôleur technique sur le fondement de l'article 1792 du code civil.". Ressalte-se que tal artigo prossegue definindo, entre outras coisas, que o seguro mencionado no primeiro parágrafo acima indicado passa a viger após a expiração da garantia de conclusão prevista no artigo 1792-6 do Código Civil, que se refere ao prazo de 1 ano como garantia de conclusão da obra, no qual fica o construtor responsável pela reparação de todas as irregularidades indicadas pelo dono da obra em seu recebimento ou após.

585،El contratista de un edificio que se arruinase por vicios de la construcción, responde de los daños y perjuicios si la ruina tuviere lugar dentro de diez años, contados desde que concluyó la construcción; igual responsabilidad, y por el mismo tiempo, tendrá el arquitecto que la dirigiere, si se debe la ruina a vicio del suelo o de la dirección.

Si la causa fuere la falta del contratista a las condiciones del contrato, la acción de indemnización durará quince años.".

${ }^{586}$ Cuja redação é a seguinte: "1. Sin perjuicio de sus responsabilidades contrac- tuales, las personas físicas o jurídicas que intervienen en el proceso de la edificación responderán frente a los propietarios y los terceros adquirentes de los edificios o parte de los mismos, en el caso de que sean objeto de división, de los siguientes daños materiales ocasio- nados en el edificio dentro de los plazos indicados, con- tados desde la fecha de recepción de la obra, sin reservas o desde la subsanación de éstas: a) Durante diez años, de los daños materiales causados en el edificio por vicios o defectos que afecten a la cimentación, los soportes, las vigas, los forjados, los muros de carga u otros elementos estructurales, y que comprometan directamente la resistencia mecánica y la estabilidad del edificio. b) Durante tres años, de los daños materiales causados en el edificio por vicios o defectos de los elementos constructivos o de las instalaciones que ocasionen el incumplimiento de los requisitos de habitabilidad del apartado 1, letra c), del artículo 3.

El constructor también responderá de los daños materiales por vicios o defectos de ejecución que afecten a elementos de terminación o acabado de las obras dentro del plazo de un año.”. 
estableciendo una responsabilidade solidariadel mismo, en todo caso, esto es, como garante." 587.

Avaliadas algumas condições atinentes à garantia pela solidez da edificação, no Brasil e em outros países, avaliar-se-ão especificidades quanto à aplicação das regras de garantia à incorporação imobiliária brasileira.

Especificamente em relação à incorporação, Everaldo Cambler acata a incidência do art. 618 a tal atividade e cita que, qualquer que seja a modalidade da incorporação, e mesmo que o incorporador não execute a construçãa ${ }^{588}$, o construtor deve responder, em razão dos altos riscos à sociedade.

Nesse mesmo sentido, Chalhub entende que o incorporador responde diretamente se se obrigar pela entrega pronta da unidade, se for o próprio construtor no caso de alienar inicialmente a fração ideal do terreno ou, de forma solidária com o construtor, se contratou a construção $^{589}$.

Considerando que o incorporador é propulsor do empreendimento, tem-se que, ainda que não seja responsável pela construção, responde pela solidez da obra ${ }^{590}$.

\footnotetext{
${ }^{587}$ CERVILLA DOMÍNGUEZ, Miguel. La responsabilidad civil de los agentes de la edificación, cit., p. 26.

${ }^{588}$ CAMBLER, Everaldo Augusto. Incorporação imobiliária: ensaio de uma teoria geral, cit., p. 246.

${ }^{589}$ CHALHUB, Melhim Namem. Da incorporação imobiliária, cit., p. 393-394.

${ }^{590}$ REsp 884367/DF, Rel. Min. Raul Araújo, Quarta Turma, STJ, julg. em 06.03.12. Ementa: "RECURSO ESPECIAL. INCORPORAÇÃO IMOBILIÁRIA. CONSTRUÇÃO DE EDIFÍCIO. VÍCIOS E DEFEITOS SURGIDOS APÓS A ENTREGA DAS UNIDADES AUTÔNOMAS AOS ADQUIRENTES. RESPONSABILIDADE SOLIDÁRIA DO INCORPORADOR E DO CONSTRUTOR. RECURSO PARCIALMENTE CONHECIDO E, NESSA PARTE, DESPROVIDO. 1. O incorporador, como impulsionador do empreendimento imobiliário em condomínio, atrai para si a responsabilidade pelos danos que possam resultar da inexecução ou da má execução do contrato de incorporação, incluindo-se aí os danos advindos de construção defeituosa. 2. A Lei no 4.591/64 estabelece, em seu art. 31, que a "iniciativa e a responsabilidade das incorporações imobiliárias caberão ao incorporador". Acerca do envolvimento da responsabilidade do incorporador pela construção, dispõe que "nenhuma incorporação poderá ser proposta à venda sem a indicação expressa do incorporador, devendo também seu nome permanecer indicado ostensivamente no local da construção", acrescentando, ainda, que "toda e qualquer incorporação, independentemente da forma por que seja constituída, terá um ou mais incorporadores solidariamente responsáveis" (art. 31, §§ $2^{\circ}$ e $3^{\circ}$ ). 3. Portanto, é o incorporador o principal garantidor do empreendimento no seu todo, solidariamente responsável com outros envolvidos nas diversas etapas da incorporação. Essa solidariedade decorre tanto da natureza da relação jurídica estabelecida entre o incorporador e o adquirente de unidades autônomas quanto de previsão legal, já que a solidariedade não pode ser presumida $(\mathrm{CC} / 2002$, caput do art. 942; CDC, art. 25, § $1^{\circ}$; Lei 4.591/64, arts. 31 e 43). 4. Mesmo quando o incorporador não é o executor direto da construção do empreendimento imobiliário, mas contrata construtor, fica, juntamente com este, responsável pela solidez e segurança da edificação (CC/2002, art. 618). Trata-se de obrigação de garantia assumida solidariamente com o construtor. 5. Recurso especial parcialmente conhecido e, nessa parte, desprovido.”.
} 
Reitere-se que, ainda que não houvesse solidariedade, se o incorporador contrata o construtor para agir em seu nome, fazendo-se substituir, é responsável por ele ${ }^{591}$.

Ainda, na modalidade de construção por administração, convém lembrar que o dono da obra são os adquirentes, podendo estes responder, portanto, nos termos do art. 937 do Código Civil ${ }^{592}$, pela ruína da construção. Entretanto, deverá ser verificada a atuação do incorporador e do construtor, ainda que os adquirentes sejam tidos como donos da obra nessa modalidade.

Avaliadas as disposições do Código Civil, é adequado proceder ao cotejo entre aquelas e as constantes do Código de Defesa do Consumidor, em relação aos prazos para reclamação de vícios, decadenciais e prescricionais ${ }^{593}$.

Inicialmente, deve-se ter em mente que o art. $6^{\circ}$ do Código de Defesa do Consumidor elenca, entre outros, um direito básico do consumidor que é "a proteção da vida, saúde e segurança contra os riscos provocados por práticas no fornecimento de produtos e serviços considerados perigosos ou nocivos".

Para Sergio Cavalieri Filho, o Código de Defesa do Consumidor aplica-se integralmente em razão da responsabilidade por fato do produto ou serviço, tendo por fato gerador o defeito do produto ou do serviço e não a conduta culposa ${ }^{594}$.

Assim, estar-se-ia diante de vício ou fato do produto ou serviço, aplicando-se, pois, o critério de garantia pela vida útil do produto, que, sendo uma edificação, pode ser maior que cinco anos previstos no Código Civil.

$\mathrm{E}$, diante do surgimento do vício ou defeito durante prazo de garantia legal, o prazo aplicável seria o decadencial, para vícios, ou o prescricional para o caso de indenização relativa aos danos causados.

Reitere-se entendimento de Claudia Lima Marques, que, com base na obrigatória garantia legal de adequação prevista no Código de Defesa do Consumidor, de que o prazo

\footnotetext{
${ }^{591}$ Conforme Aguiar Dias, "o contraente que encarrega terceiro de executar o contrato em seu nome, podendo fazê-lo, é, indiscutivelmente, responsável pelo seu representante, preposto, agente, ajudante, substituto.”. AGUIAR DIAS, José de. Da responsabilidade civil, cit., p. 195.

592،Art. 937. O dono de edifício ou construção responde pelos danos que resultarem de sua ruína, se esta provier de falta de reparos, cuja necessidade fosse manifesta."

${ }^{593}$ Como visto, o Código de Defesa do Consumidor refere-se ao prazo de 90 dias para que o consumidor reclame dos vícios constantes de bens duráveis, e de cinco anos para pretensão de danos causados por fato do produto ou serviço, conforme art. 27.

${ }^{594}$ CAVALIERI FILHO, Sergio. Programa de direito do consumidor, cit., p. 227.
} 
específico para tal garantia é o período de vida útil do bem, se se tratar de vício oculto, e, se vício aparente, "seus limites serão de 30 ou 90 dias da entrega efetiva do produto ou do término dos serviços...", sendo os prazos aplicáveis em caso de descumprimento da garantia os dos arts. 26 ou $27^{595}$.

Para a autora, a garantia legal abarca todos os vícios e não só os de solidez e segurança, sendo que ainda que haja o prazo de cinco anos do Código Civil, pelo Código de Defesa do Consumidor o vício pode aparecer a qualquer momento e, a partir do momento que for constatado, passará a contar o prazo de decadência do art. 26, parágrafo $3^{0596}$.

Esse entendimento deve ser visto com cautela, para evitar que sua aplicação crie prazo praticamente eterno para surgimento de vício ou defeito, uma vez que isso ensejaria a completa insegurança para o mercado empresarial e, como consequência econômica, maiores custos aos adquirentes.

Sendo relação de consumo, Caio Mario entende que não se aplica o prazo do parágrafo único do art. 618, mas sim o do art. 27 do Código de Defesa do Consumidor ${ }^{597}$, de forma que o consumidor terá cinco anos para propor ação.

Não obstante se tratar de relação de consumo, Toscano de Brito ${ }^{598}$ entende que a solução é utilizar o prazo decadencial do Código Civil, de 180 dias, pelo fato de ele ser maior que o prazo de 90 dias constante do art. 26 do Código de Defesa do Consumidor. Tal entendimento é embasado por julgados que deixam de aplicar o Código de Defesa do Consumidor para aplicar o art. 618, a contar da constatação do defeito da construção ${ }^{599}$.

\footnotetext{
${ }^{595}$ MARQUES, Claudia de Lima. Contratos no Código de Defesa do Consumidor: o novo regime das relações contratuais, cit., p. 1245 e ss.

${ }^{596}$ MARQUES, Claudia de Lima. Contratos no Código de Defesa do Consumidor: o novo regime das relações contratuais, cit., p. 1246.

${ }^{597}$ PEREIRA, Caio Mário da Silva. Instituições de direito civil: contratos, cit., v. 3, p. 286.

${ }^{598}$ BRITO, Rodrigo Azevedo Toscano de. Responsabilidade civil do construtor pela solidez e segurança da obra no sistema do Código Civil de 2002 e do Código de Defesa do Consumidor. In: DELGADO, Mario Luiz; ALVES, Jones Figueiredo (Coord.). Novo Código Civil: questões controvertidas. São Paulo: Ed. Método, 2003.

${ }^{599}$ Veja-se outro trecho da decisão já citada (Recurso Especial no 1.172 .331 , Terceira Turma, Rel. Min. João Otávio de Noronha, julg. em 24.09.13), que concebeu a aplicação do art. 618, sem afetar o prazo do art. 27 do Código de Defesa do Consumidor, tratando-se de vícios de grande monta, relacionados à solidez, bem como definiu que para vícios menores, aplicando-se os prazos decadenciais do código consumerista: “(...) A recepção desse dispositivo, haurido do Código Civil, a nosso aviso, não afasta a aplicação do disposto no art. 27 do CDC, que estabelece o prazo prescricional de cinco anos, contados do conhecimento do dano, para propor ação indenizatória por danos causados por fato do produto ou do serviço. [...]. Por outro lado, com relação aos vícios não estruturais, sem referibilidade com a solidez da obra, devem ser aplicados os dispositivos de responsabilidade por vícios previstos no art. 18 e segs. do Código de Defesa do Consumidor. Tratando-se de vícios ocultos - teoricamente os mais prováveis, pois a hipótese é sempre de aquisição de imóvel construído, ou seja, produto acabado - o consumidor poderá valer-se das sansões
} 
Humberto Theodoro Junior entende, por outro lado, que o art. 618 do Código Civil, referente à garantia pela solidez da obra, contém previsão mais específica, devendo, portanto, sem aplicado em detrimento das demais normas esparsas sobre vícios e defeitos $^{600}$.

Cavalieri entende que, com a aplicação do Código de Defesa do Consumidor, a responsabilidade é objetiva e, para que não responda o incorporadorlconstrutor, deve haver prova, por este, de que não havia defeito. Contudo, aplicando-se o disposto no art. 618, é dever do adquirente provar o defeito da obra, o que não o beneficia ${ }^{601}$.

Veja-se que diversidade de entendimento há.

Razão assiste à tese de especificidade do conteúdo do art. 618 do Código Civil, que já é bastante protetiva, por assegurar prazo de cinco anos de garantia da obra.

Contudo, por se tratar uma edificação construída de bem que possui vida útil altíssima, não parece que o prazo de garantia ali disposto vem proteger, de fato, os adquirentes de imóvel.

Nesse sentido, parece razoável a possibilidade do lesado de invocar as normas do Código de Defesa do Consumidor, justamente com base na confiança de que um produto de tamanho vulto que seja colocado no mercado não apresentará grave defeito, como o de solidez e o que afete a segurança ou habitabilidade.

Dessa forma, afastar-se-ia o prazo limitado de garantia do art. 618 do Código Civil, mas, não se tratando de vício menor e sim de reparação pelos danos causados, o prazo seria o prescricional do art. 27 do código consumerista, de cinco anos.

\footnotetext{
reparatórias ali previstas (substituição do produto, restituição da quantia paga ou abatimento do preço) no prazo de 90 dias contados da constatação do vício." (GRINOVER, Ada Pellegrini et al. Código Brasileiro de Defesa do Consumidor: comentado pelos autores do anteprojeto. 9. ed. Rio de Janeiro: Forense Universitária, 2007. p. 233-235.) Nenhuma dúvida há, portanto, quanto à subsunção do feito à regra do art. 26, II, da Lei n. 8.07890, que fixa em 90 dias o prazo para reclamar a remoção de vícios aparentes ou de fácil constatação, tratando-se de fornecimento de serviço e de produtos duráveis. Impõe-se, pois, o reconhecimento da decadência do direito manifestado nos presentes autos, visto que, tendo recebido as chaves do imóvel em 18/21999, somente 4 anos depois (em 20/2003) é que os autores, ora agravados, acionaram o Poder Judiciário. (...)" (sic).

${ }^{600}$ Segundo ele, "A norma do Código Civil se sobrepõe à disciplina do Código do Consumidor, mas somente tem aplicação nos defeitos graves de construção, quais sejam, os que afetam a solidez e a segurança do edifício. Os vícios menores da obra continuam submetidos ao prazo decadencial de reclamação previsto na legislação consumerista...". THEODORO JÚNIOR, Humberto. Direitos do consumidor: a busca de um ponto de equilíbrio entre as garantias do Código de Defesa do Consumidor e os princípios gerais do direito civil e do direito processual civil, cit., p. 324.

${ }^{601}$ CAVALIERI FILHO, Sergio. Programa de direito do consumidor, cit., p. 227.
} 
De uma forma ou de outra, deve haver coerência na argumentação do lesado e na aplicação das diversas normas, de forma que não haja a busca pela solução mais favorável ao adquirente, sem qualquer lógica na base de argumentação e na base decisória.

Merece destaque a obrigatoriedade da contratação de seguro de responsabilidade civil do construtor ${ }^{602}$, seguro este de danos a pessoas e a coisas. Trata-se de seguro do construtor e subcontratados, em relação a danos causados pela execução da obra, sendo de interesse dos adquirentes uma vez que estes podem ser responsabilizados solidariamente com o construtor, de acordo com os artigos 1.299, 1.277 e 1.280 do Código Civil. Segundo Chalhub $^{603}$, contudo, esse seguro não abrange a responsabilidade indicada no art. 618 do Código Civil.

\subsection{Aspectos econômicos}

É imperioso ventilar hipóteses em que o incorporador tem sua obrigação afetada por aspectos econômicos, relacionados à sua capacidade de solvência, com destaque para o processo previsto quando há instituição do patrimônio de afetação pelo incorporador.

\subsubsection{Falência do incorporador}

Tendo em vista o risco de o incorporador tornar-se insolvente, prejudicando os adquirentes, cabe a discussão quanto às consequências nessa hipótese, uma vez que a insolvência acaba por afetar a obrigação do incorporador imobiliário, inviabilizando a entrega adequada da construção e da unidade autônoma perfeita e acabada.

\footnotetext{
${ }^{602}$ Tal obrigatoriedade deriva do item "c" do art 20 do Decreto-Lei 73/66, anteriormente mencionado, que se refere ao seguro de "responsabilidade civil do construtor de imóveis em zonas urbanas por danos a pessoas ou coisas". Semelhante previsão de obrigatoriedade de seguro de responsabilidade civil para o vendedor profissional de prédio ou estrutura de um edifício construído ou para aqueles que respondem pela solidez de uma obra, sob pena de prisão de seis meses e uma multa de 75000 euros, existe no Code de la construction et de l'habitation, nos arts. 111-6-2-1 e 111-28: "Le vendeur professionnel d'un immeuble bâti ou d'une partie d'immeuble bâti, à usage d'habitation ou à usage professionnel et d'habitation, devant être rénové, doit justifier d'une assurance de responsabilité civile professionnelle." e "toute personne physique ou morale dont la responsabilité décennale peut être engagée sur le fondement de la présomption établie par les articles 1792 et suivants du code civil, reproduits aux articles L. 111-13 à L. 111-17, L. 111-20-1 et L. 111-20-2, doit être couverte par une assurance.", cumulados com o art. 111-34: "Quiconque contrevient aux dispositions des articles L. 241-1 à L. 242-1 du code des assurances, reproduits aux articles L. 111-28 à L. 111-30, sera puni d'un emprisonnement de six mois et d'une amende de 75000 euros ou de l'une de ces deux peines seulement.".

${ }^{603}$ CHALHUB, Melhim Namem. Da incorporação imobiliária, cit., p. 219.
} 
Ressalte-se, novamente, que a obrigação de entrega, na incorporação imobiliária, é de resultado, e, deixando o incorporador de cumpri-la, por qualquer motivo que não tenha o condão de afastar a responsabilidade, está obrigado pela não consecução do resultado. Ainda, o Código de Defesa do Consumidor, se aplicável na relação adquirenteincorporador, pressupõe a responsabilidade objetiva.

Deve-se atentar ao fato de a própria lei atinente a incorporação imobiliária prever medidas de forma a evitar as consequências prejudiciais aos adquirentes em casos de insolvência do incorporador.

A Lei $n^{\circ} 4.591 / 64$ prevê a falência do incorporador, em seu artigo 43, III $^{604}$, definindo que, não sendo possível à maioria dos adquirentes prosseguir na obra ${ }^{605}$, estes serão credores privilegiados pelas quantias que tenham pagado ao incorporador, respondendo subsidiariamente os bens pessoais deste ${ }^{606}$.

Entretanto, há dificuldades claras em relação ao prosseguimento da obra após falência do incorporador, considerando-se que o terreno em que se edifica pode estar no patrimônio do incorporador ${ }^{607}$.

Interessante decisão, relacionada ao caso ENCOL, em que houve mobilização de adquirentes para formação de comissão objetivando dar continuidade às obras, de forma que, com aprovação do juízo falimentar, houve substituição da ENCOL no registro imobiliário e celebração com a nova incorporadora de um contrato de promessa de permuta, para que esta concluísse o empreendimento e recebesse, em contrapartida, unidades não vendidas pela ENCOL e as unidades daqueles que não aderiram à comissão:

“(...) 2. Embora o art. 43, III, da Lei no $4.591 / 64$ não admita expressamente excluir do patrimônio da incorporadora falida e transferir para comissão formada por adquirentes de unidades a propriedade do empreendimento, de maneira a viabilizar a continuidade da obra, esse caminho constitui a melhor maneira de assegurar a funcionalidade

\footnotetext{
${ }^{604}$ Cuja redação é a seguinte: "III - em caso de falência do incorporador, pessoa física ou jurídica, e não ser possível à maioria prossequir na construção das edificações, os subscritores ou candidatos à aquisição de unidades serão credores privilegiados pelas quantias que houverem pago ao incorporador, respondendo subsidiàriamente os bens pessoais dêste;".

${ }^{605}$ Sendo aplicável o inciso VI de referido artigo, que permite a destituição do incorporador em caso de paralisação da obra ou retardo injustificado.

${ }^{606}$ SANTOS, J. A. Penalva. Obrigações e contratos na falência. 2. ed. Rio de Janeiro: Renovar, 2003. p. 66.

${ }^{607}$ Chalhub nesse sentido expõe que: "O fato, por exemplo, de o incorporador ser titular do domínio sobre o terreno torna extremamente discutível sua destituição", colocando os adquirentes em risco pela possibilidade de o produto da venda da construção executada com investimentos dos adquirentes ser utilizado pelos demais credores do insolvente. CHALHUB, Melhim Namem. Da incorporação imobiliária, cit., p. 69.
} 
econômica e preservar a função social do contrato de incorporação, do ponto de vista da coletividade dos contratantes e não dos interesses meramente individuais de seus integrantes. 3. Apesar de o legislador não excluir o direito de qualquer adquirente pedir individualmente a rescisão do contrato e o pagamento de indenização frente ao inadimplemento do incorporador, o espírito da Lei $\mathrm{n}^{\mathrm{o}} 4.591 / 64$ se volta claramente para o interesse coletivo da incorporação, tanto que seus arts. 43, III e VI, e 49, autorizam, em caso de mora ou falência do incorporador, que a administração do empreendimento seja assumida por comissão formada por adquirentes das unidades, cujas decisões, tomadas em assembleia, serão soberanas e vincularão a minoria(...)"

(REsp 1115605/RJ, Rel. Min. Nancy Andrighi, Terceira Turma, STJ, julg. em 07.04.11)

Tal decisão baseou-se em critérios de justiça, uma vez que não há exclusão expressa do patrimônio do falido quanto às unidades não vendidas do empreendimento, o que existe em caso de patrimônio de afetação.

Apesar de a lei definir que terão os adquirentes crédito privilegiado, a Lei $\mathrm{n}^{\circ}$ 11.101/05, que regula a recuperação judicial, a recuperação extrajudicial e a falência, estipula a classificação dos créditos na falência, colocando os créditos privilegiados estipulados em outra lei após os derivados da legislação trabalhista, os com garantia real e os tributários ${ }^{608}$.

Deve-se verificar, oportunamente, que a Lei $\mathrm{n}^{\mathrm{o}}$ 11.101/05 define, ainda, que, na recuperação judicial, os credores em incorporação imobiliária não terão seu direito de propriedade afetado, prevalecendo, inclusive, as condições contratuais ${ }^{609}$.

\footnotetext{
${ }^{608}$ Conforme art. 83: “A classificação dos créditos na falência obedece à seguinte ordem: I - os créditos derivados da legislação do trabalho, limitados a 150 (cento e cinqüenta) salários-mínimos por credor, e os decorrentes de acidentes de trabalho; II - créditos com garantia real até o limite do valor do bem gravado; III - créditos tributários, independentemente da sua natureza e tempo de constituição, excetuadas as multas tributárias; IV - créditos com privilégio especial, a saber: a) os previstos no art. 964 da Lei no 10.406, de 10 de janeiro de 2002; b) os assim definidos em outras leis civis e comerciais, salvo disposição contrária desta Lei; c) aqueles a cujos titulares a lei confira o direito de retenção sobre a coisa dada em garantia; V créditos com privilégio geral, a saber: a) os previstos no art. 965 da Lei no 10.406 , de 10 de janeiro de 2002; b) os previstos no parágrafo único do art. 67 desta Lei; c) os assim definidos em outras leis civis e comerciais, salvo disposição contrária desta Lei; VI - créditos quirografários, a saber: a) aqueles não previstos nos demais incisos deste artigo; b) os saldos dos créditos não cobertos pelo produto da alienação dos bens vinculados ao seu pagamento; c) os saldos dos créditos derivados da legislação do trabalho que excederem o limite estabelecido no inciso I do caput deste artigo; VII - as multas contratuais e as penas pecuniárias por infração das leis penais ou administrativas, inclusive as multas tributárias; VIII - créditos subordinados, a saber: a) os assim previstos em lei ou em contrato; b) os créditos dos sócios e dos administradores sem vínculo empregatício.".

${ }^{609}$ Nos termos do art. 49, parágrafo $3^{\text {o: }}$ "§ 30 Tratando-se de credor titular da posição de proprietário fiduciário de bens móveis ou imóveis, de arrendador mercantil, de proprietário ou promitente vendedor de imóvel cujos respectivos contratos contenham cláusula de irrevogabilidade ou irretratabilidade, inclusive
} 
Trata-se de definição que corrobora a finalidade da recuperação judicial ${ }^{610}$ e o previsto na Lei da Incorporação Imobiliária, que homenageia a continuidade do empreendimento, ainda que seja aplicável o art. $6^{0611}$, que define a suspensão do curso da prescrição e de todas as ações e execuções em face do devedor, em caso de decretação da falência ou o deferimento do processamento da recuperação judicial.

Tal suspensão tem limite, que é de cento e oitenta dias, conforme parágrafo $4^{\circ}$ do art. $6^{\circ}$ citado $^{612}$.

Em caso de falência, tem-se a definição legal de que os contratos bilaterais não se resolvem simplesmente em razão da falência, cabendo ao administrador judicial a decisão quanto ao cumprimento dos contratos ou seu término ${ }^{613}$.

Ademais, o art. 119 prevê que, em relação à promessa de compra e venda de imóveis, aplicar-se-á a legislação respectiva, e em relação aos patrimônios de afetação, constituídos para cumprimento de destinação específica, obedecer-se-á o disposto na legislação respectiva, permanecendo tal patrimônio segregado do patrimônio do falido ${ }^{614}$.

em incorporações imobiliárias, ou de proprietário em contrato de venda com reserva de domínio, seu crédito não se submeterá aos efeitos da recuperação judicial e prevalecerão os direitos de propriedade sobre a coisa e as condições contratuais, observada a legislação respectiva, não se permitindo, contudo, durante o prazo de suspensão a que se refere o $\S 40$ do art. 60 desta Lei, a venda ou a retirada do estabelecimento do devedor dos bens de capital essenciais a sua atividade empresarial.".

${ }^{610}$ Conforme art. 47: “A recuperação judicial tem por objetivo viabilizar a superação da situação de crise econômico-financeira do devedor, a fim de permitir a manutenção da fonte produtora, do emprego dos trabalhadores e dos interesses dos credores, promovendo, assim, a preservação da empresa, sua função social e o estímulo à atividade econômica.".

611 “Art. $6^{\circ}$ - A decretação da falência ou o deferimento do processamento da recuperação judicial suspende o curso da prescrição e de todas as ações e execuções em face do devedor, inclusive aquelas dos credores particulares do sócio solidário."

${ }^{612} \S 4^{\mathrm{O}} \mathrm{Na}$ recuperação judicial, a suspensão de que trata o caput deste artigo em hipótese nenhuma excederá o prazo improrrogável de 180 (cento e oitenta) dias contado do deferimento do processamento da recuperação, restabelecendo-se, após o decurso do prazo, o direito dos credores de iniciar ou continuar suas ações e execuções, independentemente de pronunciamento judicial.

${ }^{613}$ Nos termos do art. 117: "Os contratos bilaterais não se resolvem pela falência e podem ser cumpridos pelo administrador judicial se o cumprimento reduzir ou evitar o aumento do passivo da massa falida ou for necessário à manutenção e preservação de seus ativos, mediante autorização do Comitê.§ 1o O contratante pode interpelar o administrador judicial, no prazo de até 90 (noventa) dias, contado da assinatura do termo de sua nomeação, para que, dentro de 10 (dez) dias, declare se cumpre ou não o contrato. § 2o A declaração negativa ou o silêncio do administrador judicial confere ao contraente o direito à indenização, cujo valor, apurado em processo ordinário, constituirá crédito quirografário.”.

614،Art. 119. Nas relações contratuais a seguir mencionadas prevalecerão as seguintes regras: (...) VI - na promessa de compra e venda de imóveis, aplicar-se-á a legislação respectiva; (...) IX - os patrimônios de afetação, constituídos para cumprimento de destinação específica, obedecerão ao disposto na legislação respectiva, permanecendo seus bens, direitos e obrigações separados dos do falido até o advento do respectivo termo ou até o cumprimento de sua finalidade, ocasião em que o administrador judicial arrecadará o saldo a favor da massa falida ou inscreverá na classe própria o crédito que contra ela remanescer." 
Há, ainda, outro dispositivo da Lei $\mathrm{n}^{\circ} 11.101 / 05$ que pretende proteger aqueles que têm direito real, declarando-se ineficaz em relação à massa falida os registros de direito real ou averbação relativa a imóveis após a decretação da falência, exceto se tiver havido prenotação anterior à decretação ${ }^{615}$.

Apesar das disposições da nova lei de falência, editada em 2005, há certa insegurança na hipótese de recuperação ou falência do incorporador, sendo preferível, como será avaliado, a adoção do patrimônio de afetação, conforme inovação da Lei $\mathrm{n}^{\circ}$ 4.591/64, trazida em 2004, após a notória falência da ENCOL.

Cabe destacar, oportunamente, antiga decisão do STF, anteriormente à edição da Lei $n^{\circ} 4.591 / 64$, que indicava que o incorporador não era responsável pela falência do construtor, se não demonstrada sua culpa na contratação deste ${ }^{616}$. Trata-se de decisão que representa o cenário de insegurança vivido pelos adquirentes previamente à edição de aludida lei.

Veja-se que a questão da falência foi pensada pelo legislador italiano, que definiu, por meio do artigo $2^{\circ}$ do Decreto-Legislativo $n^{\circ} 122 / 2005^{617}$, uma forma específica de proteção aos adquirentes de imóveis em construção, que consiste na obrigação do construtor de assegurar ao adquirente, no momento da celebração do contrato preliminar, sob pena de nulidade deste ${ }^{618}$, uma garantia de restituição de todas as quantias pagas por

\footnotetext{
615، Art. 129 - São ineficazes em relação à massa falida, tenha ou não o contratante conhecimento do estado de crise econômico-financeira do devedor, seja ou não intenção deste fraudar credores: (...) VII - os registros de direitos reais e de transferência de propriedade entre vivos, por título oneroso ou gratuito, ou a averbação relativa a imóveis realizados após a decretação da falência, salvo se tiver havido prenotação anterior. ".

${ }^{616}$ RExt no 17065/DF, Primeira Turma, Rel. Min. Luiz Gallotti, julg. em 26.06.50: "INCORPORAÇÃO. CONTRATO PARA CONSTRUÇÃO DE EDIFICIO EM CONDOMINIO. FALÊNCIA DO CONSTRUTOR. SE NÃO SE PROVOU CULPA DO INCORPORADOR NA ESCOLHA DO CONSTRUTOR, NÃO HÁ RESPONSABILIZA-LO PELO FATO DE NÃO TER A CONSTRUÇÃO SIDO CONCLUIDA NO PRAZO PREVISTO, NEM PELO EXCESSO DE CUSTO VERIFICADO E APROVADO PELA MAIORIA DOS CONDOMINOS.’.

${ }^{617} 1$ ". All'atto della stipula di un contratto che abbia come finalità il trasferimento non immediato della proprietà o di altro diritto reale di godimento su un immobile da costruire o di un atto avente le medesime finalità, ovvero in un momento precedente, il costruttore e' obbligato, a pena di nullità del contratto che può essere fatta valere unicamente dall'acquirente, a procurare il rilascio ed a consegnare all'acquirente una fideiussione, anche secondo quanto previsto dall'articolo 1938 del codice civile, di importo corrispondente alle somme e al valore di ogni altro eventuale corrispettivo che il costruttore ha riscosso e, secondo i termini e le modalità stabilite nel contratto, deve ancora riscuotere dall'acquirente prima del trasferimento della proprietà o di altro diritto reale di godimento. Restano comunque esclusi le somme per le quali e' pattuito che debbano essere erogate da un soggetto mutuante, nonche' i contributi pubblici già assistiti da autonoma garanzia. (...)".

${ }^{618}$ Antonio Cilento, L'acquisto di immobili in costruzione tra rischio econômico e tutela della persona, cit., $\mathrm{p}$. 101 critica a estipulação de nulidade prevista no parágrafo $1^{\circ}$ do art. $2^{\circ}$ do decreto, ainda que só o adquirente possa alega-la, apontando a pertinência de o legislador determinar sanção administrativa e penal.
} 
este até a transferência de propriedade ou de outro direito real de gozo, constituindo uma espécie de fiança $^{619}$.

Evita-se, pois, que o adquirente tenha que habilitar seu crédito na falência.

Tal proteção é específica a casos de ingresso pelo incorporador em "situazione di crisi" ${ }^{620}$, abrangendo execução, processo de falência, recuperação, liquidação etc.

O adquirente, apenas nessas hipóteses, pode optar por exercer seu direito, optando pelo término do contrato e renunciando ao direito à sua execução.

Entende-se que basta o pedido do adquirente ao garantidor para que este efetue o pagamento do montante devido, não sendo aplicável o benefício de ordem que faria com que o credor se voltasse primeiro aos bens do devedor ${ }^{621}$.

Contudo, deve-se observar que o art. 72 da Lei de Falência italiana ${ }^{622}$ prevê que o curador da falência pode escolher entre o término do contrato e sua execução, tal como prevê a lei falimentar brasileira.

\footnotetext{
${ }^{619} \mathrm{~A}$ garantia deve ser lançada por banco, seguradora ou intermediário financeiro conforme prevê a lei bancaria italiana, nos termos do art. 3 do decreto em questão: " 1 . La fideiussione e' rilasciata da una banca, da un'impresa esercente le assicurazioni o da intermediari finanziari iscritti nell'elenco speciale di cui all'articolo 107 del testo unico delle leggi in materia bancaria e creditizia, di cui al decreto legislativo $1^{\circ}$ settembre 1993, n. 385, e successive modificazioni; essa deve garantire, nel caso in cui il costruttore incorra in una situazione di crisi di cui al comma 2, la restituzione delle somme e del valore di ogni altro eventuale corrispettivo effettivamente riscossi e dei relativi interessi legali maturati fino al momento in cui la predetta situazione si e' verificata.”. Conforme mencionado anteriormente, essa não é a única garantia obtida por meio de tal norma, pois o Decreto traz outras seguranças como o seguro que garante indenização, pelo prazo de dez anos, para danos resultantes da ruína, total ou defeitos de construção parcial ou grave, conforme art. 1.669 do Código Civil italiano.

${ }^{620}$ Conforme art. 1, item "c": "c) per «situazione di crisi»: la situazione che ricorre nei casi in cui il costruttore sia sottoposto o sia stato sottoposto ad esecuzione immobiliare, in relazione all'immobile oggetto del contratto, ovvero a fallimento, amministrazione straordinaria, concordato preventivo, liquidazione coatta amministrativa;". Entende-se verificada qualquer das hipóteses de acordo com o paragrafo 2 do art. 3 do decreto, apresentando-se tais hipõteses situacao definitive, afastando-se pois situacoes provisorias, que não tenham o condao de afetar a situacao economica do incorporador de forma a prejudicar o adquirente: " 2 . La situazione di crisi si intende verificata in una delle seguenti date: a) di trascrizione del pignoramento relativo all'immobile oggetto del contratto; $b$ ) di pubblicazione della sentenza dichiarativa del fallimento o del provvedimento di liquidazione coatta amministrativa; $c$ ) di presentazione della domanda di ammissione alla procedura di concordato preventivo; $d$ ) di pubblicazione della sentenza che dichiara lo stato di insolvenza o, se anteriore, del decreto che dispone la liquidazione coatta amministrativa o l'amministrazione straordinaria.". Ressalte-se, oportunamente, entendimento de Lorenzo Mezzasoma de que o rol do item "c" art. " do decreto é taxativo. Il "Consumatore" acquirente di immobili da costruire fra diritto al risparmio e diritto all'abitazione, cit., p. 173.

${ }^{621}$ Conforme CILENTO, Antonio. L'acquisto di immobili in costruzione tra rischio econômico e tutela della persona, cit., p. 99.

622، I. Se un contratto è ancora ineseguito o non compiutamente eseguito da entrambe le parti quando, nei confronti di una di esse, è dichiarato il fallimento, l'esecuzione del contratto, fatte salve le diverse disposizioni della presente Sezione, rimane sospesa fino a quando il curatore, con l'autorizzazione del comitato dei creditori, dichiara di subentrare nel contratto in luogo del fallito, assumendo tutti i relativi obblighi, ovvero di sciogliersi dal medesimo, salvo che, nei contratti ad effetti reali, sia già avvenuto il trasferimento del diritto.".
} 
Roberto Triola define que a escolha do curador é expressão do poder discricionário e pode ser exercitado sem autorização judicial específica e sem adoção de formalidade na manifestação, bastando uma clara manifestação de vontade nesse sentido do curador, inclusive em âmbito extrajudicial ${ }^{623}$.

Abre-se um processo de concorrência entre o adquirente e o curador, prevalecendo a vontade que for previamente manifestada ${ }^{624}$, em razão do disposto no art. 72 -bis ${ }^{625}$.

Importante questão é a existência de contrato de empreitada entre adquirente e construtor, caso em que haverá aplicação do art. 81 da lei de falência italiana ${ }^{626}$, que prevê que a escolha do curador pelo término do contrato apenas valerá se o contraente de boa-fé concordar e se a situação pessoal do empreiteiro for motivo essencial para a formalização do contrato ${ }^{627}$.

Via de regra, escolhendo o curador pelo término do contrato, ao adquirente cabe ingressar na massa credora em razão do valor pago ao incorporador, com privilégio de crédito, desde que o preliminar esteja registrado e seus efeitos ainda vigentes, conforme art. 2.645-bis e 2.775-bis do Código Civil italiano ${ }^{628}$.

623، (...)é espressione di un potere discrezionale ed avviene attraverso un atto che non e di straordinaria amministrazione e come tale puo essere esercitatto senza alcuna specifica autorizzazione del giudice delegato e senza ladozione di formule sacramentali, essendo suficiente una chiara manifestazione di volonta del curatore, anche per facta concludentia". TRIOLA, Roberto. Vendita di immobili da costruire e tutela dell'acquirente, cit., p. 148-149.

${ }^{624}$ MEZZASOMA, Lorenzo. Il "Consumatore" acquirente di immobili da costruire fra diritto al risparmio e diritto all'abitazione, cit., p. 176. CILENTO, Antonio. L'acquisto di immobili in costruzione tra rischio econômico e tutela della persona, cit., p. 79.

625,'I contratti di cui all'articolo 5 del decreto legislativo 20 giugno 2005, n. 122 si sciolgono se, prima che il curatore comunichi la scelta tra esecuzione o scioglimento, l'acquirente abbia escusso la fideiussione a garanzia della restituzione di quanto versato al costruttore, dandone altresì comunicazione al curatore. In ogni caso, la fideiussione non può essere escussa dopo che il curatore ha comunicato di voler dare esecuzione al contratto.”.

626“I. Il contratto di appalto si scioglie per il fallimento di una delle parti, se il curatore, previa autorizzazione del comitato dei creditori non dichiara di voler subentrare nel rapporto dandone comunicazione all'altra parte nel termine di giorni sessanta dalla dichiarazione di fallimento ed offrendo idonee garanzie. II. Nel caso di fallimento dell'appaltatore, il rapporto contrattuale si scioglie se la considerazione della qualità soggettiva è stata un motivo determinante del contratto, salvo che il committente non consenta, comunque, la prosecuzione del rapporto. Sono salve le norme relative al contratto di appalto per le opere pubbliche.”.

${ }^{627}$ Conforme MEZZASOMA, Lorenzo. Il "Consumatore" acquirente di immobili da costruire fra diritto al risparmio e diritto all abitazione, cit., p. 187.

${ }^{628}$ Conforme cita o art. 72: “(...) In caso di scioglimento del contratto preliminare di vendita immobiliare trascritto ai sensi dell'art. 2645-bis del codice civile, l'acquirente ha diritto di far valere il proprio credito nel passivo, senza che gli sia dovuto il risarcimento del danno e gode del privilegio di cui all'art. 2775-bis del codice civile a condizione che gli effetti della trascrizione del contratto preliminare non siano cessati anteriormente alla data della dichiarazione di falimento.”. 
Se a ação para execução específica da obrigação de concluir contrato definitivo for iniciada antes da declaração de falência, a sentença que a acolhe, ainda que não transcrita, é oponível à massa de credores e impede, assim, a apreensão do bem pelo curador, que não pode mais escolher pelo término do contrato ${ }^{629}$.

Mas a escolha do curador não é afetada se houver contrato de compra e venda com efeito obrigatório se antes da declaração de falência este não tiver produzido efeito translativo $^{630}$.

Em relação à denominada azione revocatória, que permite a anulação de atos que prejudiquem a massa credora, o art. 67, comma 3, letra c, da Lei de Falência italiana ${ }^{631}$, prevê que não será objeto de referida ação a venda a preço justo de imóvel a ser utilizado para fins de habitação, tanto pelo próprio adquirente, quanto por seus parentes até terceiro grau ${ }^{632}$.

Ainda, cabe indicar que o art. $9^{\circ}$ do Decreto-Lei $n^{\circ} 122 / 05^{633}$ prevê um direito de preferência na aquisição do imóvel objeto de execução, assegurando ao adquirente na

${ }^{629}$ TRIOLA, Roberto. Vendita di immobili da costruire e tutela dell'acquirente, cit., p. 151 e MEZZASOMA, Lorenzo. Il "Consumatore" acquirente di immobili da costruire fra diritto al risparmio e diritto all'abitazione, cit., p. 57.

${ }^{630}$ TRIOLA, Roberto. Vendita di immobili da costruire e tutela dell'acquirente, cit., p. 151.

631 “Non sono soggetti all'azione revocatoria: (...) c) le vendite ed i preliminari di vendita trascritti ai sensi dell'articolo 2645-bis del codice civile, i cui effetti non siano cessati ai sensi del comma terzo della suddetta disposizione, conclusi a giusto prezzo ed aventi ad oggetto immobili ad uso abitativo, destinati a costituire l'abitazione principale dell'acquirente o di suoi parenti e affini entro il terzo grado;

${ }^{632}$ Tal proteção coaduna-se com o direito constitucional a habitação, previsto no art. 47 da Constituição italiana: "La Repubblica incoraggia e tutela il risparmio in tutte le sue forme; disciplina, coordina e controlla l'esercizio del credito. Favorisce l'accesso del risparmio popolare alla proprietà dell'abitazione, alla proprietà diretta coltivatrice e al diretto e indiretto investimento azionario nei grandi complessi produttivi del Paese.”. Tal regra vai ao encontro, igualmente, do disposto no art. 10 do Decreto-Lei $n^{\circ} 122 / 05$, que determina que sao irrevogáveis os atos onerosos que tenham como objeto a transferência de propriedade ou direito real de uso, desde que feitos a justo preço e para fins de moradia do adquirente ou parente ate terceiro grau: "Art. 10. Esenzioni e limiti alla esperibilità dell'azione revocatoria fallimentare - 1 . Gli atti a titolo oneroso che hanno come effetto il trasferimento della proprietà o di altro diritto reale di godimento di immobili da costruire, nei quali l'acquirente si impegni a stabilire, entro dodici mesi dalla data di acquisto o di ultimazione degli stessi, la residenza propria o di suoi parenti o affini entro il terzo grado, se posti in essere al giusto prezzo da valutarsi alla data della stipula del preliminare, non sono soggetti all'azione revocatoria prevista dall'articolo 67 del regio decreto 16 marzo 1942, no 267, e successive modificazioni.".

633،1. Qualora l'immobile sia stato consegnato all'acquirente e da questi adibito ad abitazione principale per sé o per un proprio parente in primo grado, all'acquirente medesimo, anche nel caso in cui abbia escusso la fideiussione, e' riconosciuto il diritto di prelazione nell'acquisto dell'immobile al prezzo definitivo raggiunto nell'incanto anche in esito alle eventuali offerte ai sensi dell'articolo 584 del codice di procedura civile. 2. Ai fini dell'esercizio del diritto di prelazione, l'autorità che procede alla vendita dell'immobile provvede a dare immediata comunicazione all'acquirente, con atto notificato a mezzo ufficiale giudiziario, della definitiva determinazione del prezzo entro dieci giorni dall'adozione del relativo provvedimento, con indicazione di tutte le condizioni alle quali la vendita dovrà essere conclusa e l'invito ad esercitare la prelazione. 3. Il diritto di prelazione e' esercitato dall'acquirente, a pena di decadenza, entro il termine di dieci giorni dalla data di ricezione della comunicazione di cui al comma 2 offrendo, con atto notificato a mezzo ufficiale giudiziario all'autorità che procede alla vendita dell'immobile, condizioni uguali a quelle comunicategli. 4. Qualora l'acquirente abbia acquistato l'immobile, per effetto dell'esercizio del diritto di prelazione, ad un prezzo inferiore alle somme riscosse in sede di escussione della fideiussione, la differenza 
posse do imóvel com finalidade de habitação própria ou por parente até o primeiro grau a aquisição ao preço definitivo do bem ${ }^{634}$.

No direito francês, por exemplo, o art. 1.831-5 do Código Civil, reproduzido no art. 221-5 do Code de la construction et de l'habitation, prevê que o contrato de "promotion immobilière" não é afetado pela liquidação da empresa ${ }^{635}$, assegurando-se, assim, a continuidade do empreendimento, ou, pelo menos, que os bens do empreendimento não sejam levados à massa.

Em síntese, cabe avaliar a instituição do patrimônio de afetação, que, como se verá, é mais benéfico ao adquirente.

\subsubsection{O patrimônio de afetação}

Inicialmente, não obstante o conceito de que o patrimônio de uma pessoa é considerado um conjunto de bens, direitos e obrigações que forma uma universalidade de direito $^{636}$, desenvolveu-se a ideia de afetação do patrimônio, que é, na lição de Melhim Chalhub, instituto que se relaciona com o negócio fiduciário e o trust norte-americano, por propiciar a proteção de credores em razão da determinação da finalidade de tal patrimônio, só podendo ser utilizado para seu fim específico, e da consequente limitação da responsabilidade, respondendo tal patrimônio afetado por obrigações e responsabilidades que dele nascem ${ }^{637}$.

\footnotetext{
deve essere restituita al fideiussore, qualora l'immobile acquistato abbia consistenza e caratteristiche tipologiche e di finitura corrispondenti a quelle previste nel contratto stipulato con il costruttore. Ove non ricorra tale condizione, l'eventuale eccedenza da restituire al fideiussore deve risultare da apposita stima. 5. E' escluso, in ogni caso, il diritto di riscatto nei confronti dell'aggiudicatario."

${ }^{634}$ CILENTO, Antonio. L'acquisto di immobili in costruzione tra rischio econômico e tutela della persona, cit., p. 82.

${ }^{635}$ "Le règlement judiciaire ou la liquidation des biens n'entrâne pas de plein droit la résiliation du contrat de promotion immobilière. Toute stipulation contraire est réputée non écrite."

${ }^{636}$ Verifica-se que o Código Civil, em seus arts. 90 e 91 , prevê a possibilidade de criação de universalidades de fato e de direito: "Art. 90. Constitui universalidade de fato a pluralidade de bens singulares que, pertinentes à mesma pessoa, tenham destinação unitária. Parágrafo único. Os bens que formam essa universalidade podem ser objeto de relações jurídicas próprias." e "Art. 91. Constitui universalidade de direito o complexo de relações jurídicas, de uma pessoa, dotadas de valor econômico.".

${ }^{637}$ CHALHUB, Melhim Namem. Negócio fiduciário, cit., p. 66 e 71.
} 
No Direito brasileiro, há definição da segregação de patrimônio, em casos de fundos de investimentos e securitização de crédito, conforme Leis no 4.864/65 e 9.514/97, assim como em relação à incorporação imobiliária ${ }^{638}$, entre outras hipóteses.

No que se refere à incorporação imobiliária, o regime de afetação de patrimônio passou a ser previsto por meio da Medida Provisória $n^{\circ}$ 2.221/2001, que criou o regime de afetação, sendo que a Lei $\mathrm{n}^{\mathrm{o}} 10.931 / 2004$, editada posteriormente a tal medida, incluiu alteração à Lei no 4.591/64, adicionando os arts. 31-A a 31-F.

Tanto a Medida Provisória citada quanto a Lei $\mathrm{n}^{\mathbf{o}}$ 10.931/2004 tinham como finalidade o aumento da proteção dada aos adquirentes, especialmente como consequência do famoso caso da falência da ENCOL, que demonstrou a fragilidade do regime, ao expor tantos adquirentes de boa-fé à perda de valores pagos na expectativa de se adquirir imóvel, uma vez que os recursos destinados à construção da edificação e da unidade autônoma eram misturados com os recursos do incorporador ${ }^{639}$.

Com o patrimônio de afetação assegurou-se maior proteção àqueles em razão de ser um patrimônio segregado do patrimônio do incorporador, voltado, especificamente, para a realização de uma determinada incorporação, não se confundindo, contudo, com a criação de sociedade de propósito específico, comumente denominada "SPE", ainda que tal criação tenha, de certa forma, a mesma finalidade de segregação de bens.

O patrimônio de afetação não foi criado apenas para proteção dos adquirentes, mas de todos os envolvidos na incorporação imobiliária, ou seja, todos aqueles que têm direitos de créditos relacionados a determinado empreendimento são beneficiados, pois sabem que os recursos afetados ao empreendimento serão utilizados exclusivamente para pagamento de dívidas contraídas em razão desse empreendimento.

\footnotetext{
${ }^{638}$ Há instituição de patrimônio de afetação no âmbito da securitização de créditos, sendo que a Lei $\mathrm{n}^{\circ}$ 9.514/97 define que os créditos do ativo de companhia securitizadora integram o patrimônio de tal companhia, mas são destacados e recebem tratamento especial, para satisfação dos créditos de subscritores dos certificados de recebíveis imobiliários - CRI: “Art. 10. O regime fiduciário será instituído mediante declaração unilateral da companhia securitizadora no contexto do Termo de Securitização de Créditos, que, além de conter os elementos de que trata o art. $8^{\circ}$, submeter-se-á às seguintes condições: I - a constituição do regime fiduciário sobre os créditos que lastreiem a emissão; II - a constituição de patrimônio separado, integrado pela totalidade dos créditos submetidos ao regime fiduciário que lastreiem a emissão; III - a afetação dos créditos como lastro da emissão da respectiva série de títulos; (...)".

${ }^{639}$ FRANCISCO, Caramuru Afonso. O novo regime jurídico dos contratos: das incorporações e do registro imobiliário e da alienação fiduciária em garantia, cit., p. 62. Nos termos do art. 31-A: "Art. 31-A. A critério do incorporador, a incorporação poderá ser submetida ao regime da afetação, pelo qual o terreno e as acessões objeto de incorporação imobiliária, bem como os demais bens e direitos a ela vinculados, manter-se-ão apartados do patrimônio do incorporador e constituirão patrimônio de afetação, destinado à consecução da incorporação correspondente e à entrega das unidades imobiliárias aos respectivos adquirentes.".
} 
Essa é a principal utilidade do patrimônio segregado, pois demarca os direitos e as obrigações atinentes ao propósito de tal patrimônio, em razão da destinação específica de seus bens, que os afasta das consequências da insolvência ou falência das partes ${ }^{640}$.

A instituição do patrimônio de afetação, conforme parte inicial do art. 31-A, fica a critério do incorporador, ou seja, é escolha deste, indo ao encontro, exemplificativamente, do disposto no Código Civil italiano ${ }^{641}$.

Chalhub critica a opção do legislador de deixar a critério do incorporador a instituição do patrimônio de afetação, uma vez que entende tal instituição como um elemento natural do contrato e que "A prerrogativa conferida à incorporadora constitui privilégio incompatível com a atividade de captação de recursos do público e com o interesse da economia popular." $" 642$.

Apesar de ser opção do incorporador, na prática, os adquirentes devem se precaver e contratar, preferencialmente, imóveis em empreendimentos em que houve essa opção.

Nos termos do art. 31-B ${ }^{643}$, a instituição do patrimônio de afetação dá-se por meio da averbação no Cartório de Registro de Imóveis de termo firmado pelo incorporador e eventuais titulares de direitos reais de aquisição sobre o terreno, o que pode ser feito a qualquer momento, ainda que iniciada a incorporação.

O parágrafo único do citado artigo indica, ainda, que a instituição do patrimônio de afetação não depende da manifestação de credores que tenham garantias reais sobre o

\footnotetext{
${ }^{640}$ Nos termos do art. 31 -A e parágrafo $1^{\text {o: }}$ "A critério do incorporador, a incorporação poderá ser submetida ao regime da afetação, pelo qual o terreno e as acessões objeto de incorporação imobiliária, bem como os demais bens e direitos a ela vinculados, manter-se-ão apartados do patrimônio do incorporador e constituirão patrimônio de afetação, destinado à consecução da incorporação correspondente e à entrega das unidades imobiliárias aos respectivos adquirentes. $\S 1^{\circ} \mathrm{O}$ patrimônio de afetação não se comunica com os demais bens, direitos e obrigações do patrimônio geral do incorporador ou de outros patrimônios de afetação por ele constituídos e só responde por dívidas e obrigações vinculadas à incorporação respectiva". (grifos da autora)

${ }^{641}$ Os artigos 2.447-bis a 2.447-decies preveem a afetação como faculdade das empresas. Não obstante, a Lei 130/99 estipula a obrigação de afetação em casos de fundos de investimento e de securitização de crédito, tal qual a lei francesa 211/1997, que estabelece separação patrimonial dos bens e obrigações vinculados a relações jurídicas fiduciárias e da propriedade fiduciária como explana Chalhub, em CHALHUB, Melhim Namem. Alienação fiduciária, incorporação imobiliária e mercado de capitais: estudos e pareceres, cit., p. 256-257.

${ }^{642}$ CHALHUB, Melhim Namem. Alienação fiduciária, incorporação imobiliária e mercado de capitais: estudos e pareceres, cit., p. 263.

643“"Art. 31-B. Considera-se constituído o patrimônio de afetação mediante averbação, a qualquer tempo, no Registro de Imóveis, de termo firmado pelo incorporador e, quando for o caso, também pelos titulares de direitos reais de aquisição sobre o terreno. Parágrafo único. A averbação não será obstada pela existência de ônus reais que tenham sido constituídos sobre o imóvel objeto da incorporação para garantia do pagamento do preço de sua aquisição ou do cumprimento de obrigação de construir o empreendimento.”
} 
terreno objeto da incorporação e não é obstada pela existência de ônus reais que tenham sido constituídos sobre o imóvel objeto da incorporação.

Apesar da desnecessidade de obtenção de anuência dos credores para instituição do patrimônio de afetação, a lei fez depender a venda de imóveis da anuência da instituição financeira financiadora da incorporação ${ }^{644}$.

O patrimônio de afetação é constituído pelo terreno em que se erguerá a edificação, acessões, bens e direitos a esses vinculados, bem como pelas dívidas e obrigações constituídas em relação à correspondente incorporação.

Acerca do art. 31-A, parágrafo terceiro ${ }^{645}$, que prevê que os bens e direitos que compõem o patrimônio de afetação somente poderão ser objeto de garantia real em operação de crédito cujo produto seja integralmente destinado à consecução da edificação, Caramuru, com razão, afirma que, se fosse de outra forma, estaríamos diante de nulidade, porque se estabeleceria operação de crédito cujo produto não seria revertido para os objetivos daquela incorporação ${ }^{646}$.

Isto pois os direitos e obrigações da incorporação em que se instituiu o patrimônio de afetação, incluindo-se o terreno, as acessões, as receitas da venda etc,. são vinculados ao negócio específico do empreendimento a que estão ligados, respondendo, pois, pelas obrigações contraídas para tal finalidade ${ }^{647}$.

O parágrafo quarto do art. 31-A estabelece a vinculação ao patrimônio de afetação dos direitos surgidos de cessão de direitos creditórios advindos da comercialização de unidades de determinada incorporação.

Não obstante a afetação do patrimônio ora tratado, a lei define que serão segregados da finalidade do patrimônio os valores que excedam o necessário para a conclusão da obra, inclusive os recursos necessários para quitar eventual financiamento para a construção ou excederem o valor da venda de fração ideal de terreno de unidade

\footnotetext{
${ }^{644}$ Conforme se depreende do art. 31-A, § 11: "Nas incorporações objeto de financiamento, a comercialização das unidades deverá contar com a anuência da instituição financiadora ou deverá ser a ela cientificada, conforme vier a ser estabelecido no contrato de financiamento.".

${ }^{645 ،} \S 3^{3}$ Os bens e direitos integrantes do patrimônio de afetação somente poderão ser objeto de garantia real em operação de crédito cujo produto seja integralmente destinado à consecução da edificação correspondente e à entrega das unidades imobiliárias aos respectivos adquirentes."

${ }^{646}$ FRANCISCO, Caramuru Afonso. O novo regime jurídico dos contratos: das incorporações e do registro imobiliário e da alienação fiduciária em garantia, cit., p. 73.

${ }^{647}$ Como se depreende do $\S 6^{0}$ do art. 31-A: "Os recursos financeiros integrantes do patrimônio de afetação serão utilizados para pagamento ou reembolso das despesas inerentes à incorporação.”.
} 
vendida se a incorporação for contratada sob o regime da empreitada ou da $\operatorname{administração~}^{648}$.

A incorporadora só poderá se apropriar dos resultados obtidos após a conclusão do empreendimento.

O incorporador deve administrar o patrimônio de afetação, sendo seu representante. Assim, responde pelos prejuízos que vier a causar a ele, nos termos do parágrafo segundo do art. 31- $\mathrm{A}^{649}$, tendo outros deveres jurídicos, conforme art. 31-D de citada lei, como promover atos necessários à sua preservação, inclusive mediante proposição de medidas judiciais; não misturar bens e direitos de cada incorporação; movimentar recursos em conta de depósito aberta especificamente para tal fim; e prestar contas a cada três meses ${ }^{650}$.

A afetação não exonera o incorporador de suas responsabilidades, inclusive com seus bens pessoais, devendo suprir os recursos para execução da obra caso a receita própria do negócio não seja suficiente para sua consecução ${ }^{651}$.

O patrimônio de afetação extingue-se por averbação da construção, que é entendida como o término do contrato de incorporação imobiliária; pelo registro do domínio ou de direito de aquisição em nome dos adquirentes; e, se aplicável, pela extinção

\footnotetext{
${ }^{648}$ De acordo com a seguinte previsão: "§ $8^{\circ}$ Excluem-se do patrimônio de afetação: I - os recursos financeiros que excederem a importância necessária à conclusão da obra (art. 44), considerando-se os valores a receber até sua conclusão e, bem assim, os recursos necessários à quitação de financiamento para a construção, se houver; II - o valor referente ao preço de alienação da fração ideal de terreno de cada unidade vendida, no caso de incorporação em que a construção seja contratada sob o regime por empreitada (art. 55) ou por administração (art. 58).’.

${ }^{649} \S 2^{\mathrm{o}} \mathrm{O}$ incorporador responde pelos prejuízos que causar ao patrimônio de afetação.

${ }^{650}$ Art. 31-D. Incumbe ao incorporador: I - promover todos os atos necessários à boa administração e à preservação do patrimônio de afetação, inclusive mediante adoção de medidas judiciais; II - manter apartados os bens e direitos objeto de cada incorporação; III - diligenciar a captação dos recursos necessários à incorporação e aplicá-los na forma prevista nesta Lei, cuidando de preservar os recursos necessários à conclusão da obra; IV - entregar à Comissão de Representantes, no mínimo a cada três meses, demonstrativo do estado da obra e de sua correspondência com o prazo pactuado ou com os recursos financeiros que integrem o patrimônio de afetação recebidos no período, firmados por profissionais habilitados, ressalvadas eventuais modificações sugeridas pelo incorporador e aprovadas pela Comissão de Representantes; V - manter e movimentar os recursos financeiros do patrimônio de afetação em conta de depósito aberta especificamente para tal fim; VI - entregar à Comissão de Representantes balancetes coincidentes com o trimestre civil, relativos a cada patrimônio de afetação; VII - assegurar à pessoa nomeada nos termos do art. 31-C o livre acesso à obra, bem como aos livros, contratos, movimentação da conta de depósito exclusiva referida no inciso $\mathrm{V}$ deste artigo e quaisquer outros documentos relativos ao patrimônio de afetação; e VIII - manter escrituração contábil completa, ainda que esteja desobrigado pela legislação tributária."

${ }^{651}$ CHALHUB, Melhim Namem. Negócio fiduciário, cit., p. 95. CAMINHA, Uinie. Securitização. São Paulo: Ed. Saraiva, 2005. p. 151, igualmente menciona que o incorporador pode responder com seu patrimônio geral e pessoal se causar prejuízo ao patrimônio afetado.
} 
das obrigações do incorporador perante a instituição financeira que financiou o empreendimento $^{652}$.

Ressalte-se a necessidade de averbação do cancelamento da averbação da instituição do patrimônio de afetação, o que depende da prova de quitação do financiamento da obra.

Há, ainda, duas outras formas de extinção do patrimônio, conforme art. 31-E: (i) a "revogação" da incorporação, no prazo de carência da incorporação, desde que haja restituição de valores aos adquirentes, no prazo de trinta dias, conforme arts. 32 e 34 da Lei $n^{\circ}$ 4.591/64; e (ii) a liquidação deliberada pela Assembleia Geral dos adquirentes a ser realizada em sessenta dias, no caso de falência ou insolvência civil do incorporador.

Cabe-nos analisar especificamente as consequências da falência ou insolvência do incorporador, hipótese esta prevista no art. 31-F da lei em questão ${ }^{653}$.

\footnotetext{
652، Art. 31-E. O patrimônio de afetação extinguir-se-á pela: I - averbação da construção, registro dos títulos de domínio ou de direito de aquisição em nome dos respectivos adquirentes e, quando for o caso, extinção das obrigações do incorporador perante a instituição financiadora do empreendimento; II - revogação em razão de denúncia da incorporação, depois de restituídas aos adquirentes as quantias por eles pagas (art. 36), ou de outras hipóteses previstas em lei; e III - liquidação deliberada pela assembléia geral nos termos do art. 31-F, § 10.”.

653،"Art. 31-F. Os efeitos da decretação da falência ou da insolvência civil do incorporador não atingem os patrimônios de afetação constituídos, não integrando a massa concursal o terreno, as acessões e demais bens, direitos creditórios, obrigações e encargos objeto da incorporação. § 1o Nos sessenta dias que se seguirem à decretação da falência ou da insolvência civil do incorporador, o condomínio dos adquirentes, por convocação da sua Comissão de Representantes ou, na sua falta, de um sexto dos titulares de frações ideais, ou, ainda, por determinação do juiz prolator da decisão, realizará assembléia geral, na qual, por maioria simples, ratificará o mandato da Comissão de Representantes ou elegerá novos membros, e, em primeira convocação, por dois terços dos votos dos adquirentes ou, em segunda convocação, pela maioria absoluta desses votos, instituirá o condomínio da construção, por instrumento público ou particular, e deliberará sobre os termos da continuação da obra ou da liquidação do patrimônio de afetação (art. 43, inciso III); havendo financiamento para construção, a convocação poderá ser feita pela instituição financiadora. § $20 \mathrm{O}$ disposto no $\S 10$ aplica-se também à hipótese de paralisação das obras prevista no art. 43, inciso VI. § 3o Na hipótese de que tratam os $\S 1$ o e 2o, a Comissão de Representantes ficará investida de mandato irrevogável para firmar com os adquirentes das unidades autônomas o contrato definitivo a que estiverem obrigados o incorporador, o titular do domínio e o titular dos direitos aquisitivos do imóvel objeto da incorporação em decorrência de contratos preliminares.§ 4o O mandato a que se refere o $\S 30$ será válido mesmo depois de concluída a obra. § 5o O mandato outorgado à Comissão de Representantes confere poderes para transmitir domínio, direito, posse e ação, manifestar a responsabilidade do alienante pela evicção e imitir os adquirentes na posse das unidades respectivas.§ 6o Os contratos definitivos serão celebrados mesmo com os adquirentes que tenham obrigações a cumprir perante o incorporador ou a instituição financiadora, desde que comprovadamente adimplentes, situação em que a outorga do contrato fica condicionada à constituição de garantia real sobre o imóvel, para assegurar o pagamento do débito remanescente. $\S 7$ o Ainda na hipótese dos $\S$ 1o e 2o, a Comissão de Representantes ficará investida de mandato irrevogável para, em nome dos adquirentes, e em cumprimento da decisão da assembléia geral que deliberar pela liquidação do patrimônio de afetação, efetivar a alienação do terreno e das acessões, transmitindo posse, direito, domínio e ação, manifestar a responsabilidade pela evicção, imitir os futuros adquirentes na posse do terreno e das acessões. $\S 80 \mathrm{Na}$ hipótese do $\S 7 \mathrm{o}$, será firmado o respectivo contrato de venda, promessa de venda ou outra modalidade de contrato compatível com os direitos objeto da transmissão. § 9o A Comissão de Representantes cumprirá o mandato nos termos e nos limites
} 
estabelecidos pela deliberação da assembléia geral e prestará contas aos adquirentes, entregando-lhes o produto líquido da alienação, no prazo de cinco dias da data em que tiver recebido o preço ou cada parcela do preço.§ 10. Os valores pertencentes aos adquirentes não localizados deverão ser depositados em Juízo pela Comissão de Representantes. § 11. Caso decidam pela continuação da obra, os adquirentes ficarão automaticamente sub-rogados nos direitos, nas obrigações e nos encargos relativos à incorporação, inclusive aqueles relativos ao contrato de financiamento da obra, se houver. $\S 12$. Para os efeitos do $\S 11$ deste artigo, cada adquirente responderá individualmente pelo saldo porventura existente entre as receitas do empreendimento e o custo da conclusão da incorporação na proporção dos coeficientes de construção atribuíveis às respectivas unidades, se outro critério de rateio não for deliberado em assembléia geral por dois terços dos votos dos adquirentes, observado o seguinte: I - os saldos dos preços das frações ideais e acessões integrantes da incorporação que não tenham sido pagos ao incorporador até a data da decretação da falência ou da insolvência civil passarão a ser pagos à Comissão de Representantes, permanecendo o somatório desses recursos submetido à afetação, nos termos do art. 31-A, até o limite necessário à conclusão da incorporação; II - para cumprimento do seu encargo de administradora da incorporação, a Comissão de Representantes fica investida de mandato legal, em caráter irrevogável, para, em nome do incorporador ou do condomínio de construção, conforme o caso, receber as parcelas do saldo do preço e dar quitação, bem como promover as medidas extrajudiciais ou judiciais necessárias a esse recebimento, praticando todos os atos relativos ao leilão de que trata o art. 63 ou os atos relativos à consolidação da propriedade e ao leilão de que tratam os arts. 26 e 27 da Lei no 9.514, de 20 de novembro de 1997, devendo realizar a garantia e aplicar na incorporação todo o produto do recebimento do saldo do preço e do leilão; III - consideram-se receitas do empreendimento os valores das parcelas a receber, vincendas e vencidas e ainda não pagas, de cada adquirente, correspondentes ao preço de aquisição das respectivas unidades ou do preço de custeio de construção, bem como os recursos disponíveis afetados; e IV - compreendem-se no custo de conclusão da incorporação todo o custeio da construção do edifício e a averbação da construção das edificações para efeito de individualização e discriminação das unidades, nos termos do art. 44. § 13. Havendo saldo positivo entre as receitas da incorporação e o custo da conclusão da incorporação, o valor correspondente a esse saldo deverá ser entregue à massa falida pela Comissão de Representantes. § 14. Para assegurar as medidas necessárias ao prosseguimento das obras ou à liquidação do patrimônio de afetação, a Comissão de Representantes, no prazo de sessenta dias, a contar da data de realização da assembléia geral de que trata o $§ 10$, promoverá, em leilão público, com observância dos critérios estabelecidos pelo art. 63, a venda das frações ideais e respectivas acessões que, até a data da decretação da falência ou insolvência não tiverem sido alienadas pelo incorporador. $\$ 15$. Na hipótese de que trata o $\S 14$, o arrematante ficará sub-rogado, na proporção atribuível à fração e acessões adquiridas, nos direitos e nas obrigações relativas ao empreendimento, inclusive nas obrigações de eventual financiamento, e, em se tratando da hipótese do art. 39 desta Lei, nas obrigações perante o proprietário do terreno. $\S 16$. Dos documentos para anúncio da venda de que trata o $\S 14$ e, bem assim, o inciso III do art. 43, constarão o valor das acessões não pagas pelo incorporador (art. 35, § 6o) e o preço da fração ideal do terreno e das acessões (arts. 40 e 41 ). $§ 17$. No processo de venda de que trata o $§ 14$, serão asseguradas, sucessivamente, em igualdade de condições com terceiros: I - ao proprietário do terreno, nas hipóteses em que este seja pessoa distinta da pessoa do incorporador, a preferência para aquisição das acessões vinculadas à fração objeto da venda, a ser exercida nas vinte e quatro horas seguintes à data designada para a venda; e II - ao condomínio, caso não exercida a preferência de que trata o inciso I, ou caso não haja licitantes, a preferência para aquisição da fração ideal e acessões, desde que deliberada em assembléia geral, pelo voto da maioria simples dos adquirentes presentes, e exercida no prazo de quarenta e oito horas a contar da data designada para a venda. $\S 18$. Realizada a venda prevista no $\S 14$, incumbirá à Comissão de Representantes, sucessivamente, nos cinco dias que se seguirem ao recebimento do preço: I - pagar as obrigações trabalhistas, previdenciárias e tributárias, vinculadas ao respectivo patrimônio de afetação, observada a ordem de preferência prevista na legislação, em especial o disposto no art. 186 do Código Tributário Nacional; II - reembolsar aos adquirentes as quantias que tenham adiantado, com recursos próprios, para pagamento das obrigações referidas no inciso I; III - reembolsar à instituição financiadora a quantia que esta tiver entregue para a construção, salvo se outra forma for convencionada entre as partes interessadas; IV - entregar ao condomínio o valor que este tiver desembolsado para construção das acessões de responsabilidade do incorporador ( $\$ 60$ do art. 35 e $\S 50$ do art. 31-A), na proporção do valor obtido na venda; V - entregar ao proprietário do terreno, nas hipóteses em que este seja pessoa distinta da pessoa do incorporador, o valor apurado na venda, em proporção ao valor atribuído à fração ideal; e VI - entregar à massa falida o saldo que porventura remanescer. $\S 19$. O incorporador deve assegurar à pessoa nomeada nos termos do art. 31-C, o acesso a todas as informações necessárias à verificação do montante das obrigações referidas no $\S 12$, inciso I, do art. 31-F vinculadas ao respectivo patrimônio de afetação. § 20. Ficam excluídas da responsabilidade dos adquirentes as obrigações relativas, de maneira direta ou indireta, ao imposto de renda 
Em caso de falência do incorporador, o acervo correspondente à incorporação afetada não será arrecadado, sendo, contudo, entregue à administração da Comissão de Representantes dos adquirentes, que poderá prosseguir com as obras, com o recurso obtido dos adquirentes, tendo estes crédito contra a massa se faltarem recursos para conclusão da obra ${ }^{654}$.

Assim, após decretada a falência, os bens integrantes desse patrimônio de afetação continuarão separados dos demais bens do falido, de forma a garantir que aqueles sejam utilizados para a finalidade própria daquele patrimônio de afetação.

No prazo de sessenta dias, haverá deliberação, pelo condomínio dos adquirentes, em Assembleia geral, na qual poderá ser ratificado o mandato da Comissão de Representantes ou eleitos novos membros.

Após, em primeira convocação, por dois terços dos votos dos adquirentes ou, em segunda convocação, pela maioria absoluta desses votos, haverá instituição do condomínio da construção, já que o patrimônio, agora, não é mais administrado pelo incorporador, mas sim pelos adquirentes, e se deliberará sobre as condições da continuação da obra ou da liquidação do patrimônio de afetação.

A opção de continuidade do empreendimento é ratificada pela previsão da Lei $n^{\circ}$ 11.101/2005, que indica que as atividades relacionadas a patrimônio de afetação prosseguirão independentemente do processo de falência ${ }^{655}$.

A possibilidade de os adquirentes substituírem o incorporador teoricamente privilegia a continuidade da obra. Contudo, deve-se analisar com parcimônia essa possibilidade, pelos inconvenientes causados no regular andamento do empreendimento.

$\mathrm{O}$ artigo $9^{\circ}$ da Lei $\mathrm{n}^{\mathrm{o}} 10.931 / 2004^{656}$ dispõe que os adquirentes, para continuarem na obra, terão que pagar as dívidas fiscais, previdenciárias e trabalhistas do

e à contribuição social sobre o lucro, devidas pela pessoa jurídica do incorporador, inclusive por equiparação, bem como as obrigações oriundas de outras atividades do incorporador não relacionadas diretamente com as incorporações objeto de afetação."

${ }^{654}$ CHALHUB, Melhim Namem. Negócio fiduciário, cit., p. 79.

${ }^{655}$ Conforme art. 119, IX: "IX - os patrimônios de afetação, constituídos para cumprimento de destinação específica, obedecerão ao disposto na legislação respectiva, permanecendo seus bens, direitos e obrigações separados dos do falido até o advento do respectivo termo ou até o cumprimento de sua finalidade, ocasião em que o administrador judicial arrecadará o saldo a favor da massa falida ou inscreverá na classe própria o crédito que contra ela remanescer."

656، “Art. $9^{\circ}$ - Perde eficácia a deliberação pela continuação da obra a que se refere o $§ 10$ do art. 31-F da Lei no 4.591, de 1964, bem como os efeitos do regime de afetação instituídos por esta Lei, caso não se verifique o pagamento das obrigações tributárias, previdenciárias e trabalhistas, vinculadas ao respectivo patrimônio de afetação, cujos fatos geradores tenham ocorrido até a data da decretação da falência, ou insolvência do incorporador, as quais deverão ser pagas pelos adquirentes em até um ano daquela deliberação, ou até a data da concessão do habite-se, se esta ocorrer em prazo inferior.” 
empreendimento no prazo de um ano ${ }^{657}$, com exclusão, contudo, das obrigações relativas ao imposto de renda e à contribuição social sobre o lucro, por se referirem exclusivamente à atividade do incorporador ${ }^{658}$.

Caso não haja quitação no prazo mencionado em referido artigo, os adquirentes não podem prosseguir com a obra e, para Chalhub, há prejuízo para os adquirentes, uma vez que há interrupção no fluxo de pagamentos que constitui fonte de recursos destinados ao pagamento dos créditos vinculados ao negócio, assim como para os trabalhadores da obra, que não terão a continuidade dos seus contratos de trabalho, além de que eventual crédito trabalhista será concorrente com os demais habilitados na falência da incorporadora ${ }^{659}$.

Em relação ao pagamento de dívidas do empreendimento, a crítica feita pelo autor não merece albergue, pois o patrimônio de afetação é criado justamente para se constituir recurso para pagamento de obrigações decorrentes do empreendimento em questão.

Além disso, as obrigações imputadas aos adquirentes que decidam pela continuidade das obras não devem exceder o preço de aquisição das unidades autônomas, pois qualquer acréscimo nos preços importaria violação do princípio da comutatividade presente no contrato de incorporação.

Não obstante, eventual paralisação da obra por não pagamento de obrigações em tão curto prazo pode ser, de fato, prejudicial, pela interrupção no fluxo de pagamentos e sob a ótica trabalhista.

Caso prossigam nas obras, os adquirentes subrogam-se nos direitos e deveres do incorporador, inclusive perante a instituição financeira financiadora do empreendimento, nos termos do parágrafo $11^{\circ}$ do art. $31-\mathrm{F}$ da Lei $n^{\circ} 4.591 / 64^{660}$.

\footnotetext{
657،“Art. $9^{\circ}$ - A companhia securitizadora poderá instituir regime fiduciário sobre créditos imobiliários, a fim de lastrear a emissão de Certificados de Recebíveis Imobiliários, sendo agente fiduciário uma instituição financeira ou companhia autorizada para esse fim pelo BACEN e beneficiários os adquirentes dos títulos lastreados nos recebíveis objeto desse regime."

${ }^{658}$ Quanto à exclusão do imposto de renda, no mesmo sentido o parágrafo 20 do art. 31-F: "§ 20. Ficam excluídas da responsabilidade dos adquirentes as obrigações relativas, de maneira direta ou indireta, ao imposto de renda e à contribuição social sobre o lucro, devidas pela pessoa jurídica do incorporador, inclusive por equiparação, bem como as obrigações oriundas de outras atividades do incorporador não relacionadas diretamente com as incorporações objeto de afetação

${ }^{659}$ CHALHUB, Melhim Namem. Alienação fiduciária, incorporação imobiliária e mercado de capitais: estudos e pareceres, cit., p. 268. E Negócio fiduciário, cit., p. 97-98.

660،§ 11. Caso decidam pela continuação da obra, os adquirentes ficarão automaticamente sub-rogados nos direitos, nas obrigações e nos encargos relativos à incorporação, inclusive aqueles relativos ao contrato de financiamento da obra, se houver."
} 
Regulando o parágrafo citado, a lei, ainda, define que cada adquirente será responsável pelo saldo existente entre as receitas do empreendimento e o custo da incorporação, na proporção da fração correspondente à sua própria unidade, observandose, especialmente, que a Comissão de Representantes recebe poderes, em caráter irrevogável, para, em nome do incorporador, receber parcelas do saldo do preço e dar quitação, bem como promover as medidas necessárias para cobrança dos valores ${ }^{661}$.

Medida salutar é a previsão dos poderes da Comissão para promover leilão público, conforme art. 63 da lei, para venda das frações ideais e respectivas acessões que não tenham sido alienadas pelo incorporador até a data da decretação da falência ou insolvência.

Ressalte-se julgamento no caso da ENCOL, anteriormente citado, de que, apesar de não haver previsão em sentido similar, foram transferidas, aos adquirentes, as unidades em estoque, não vendidas pelo incorporador, para permitir prosseguimento do empreendimento.

Ainda, a Comissão recebe poderes para, nos termos do parágrafo $3^{\circ}$ do art. 31$\mathrm{F}^{662}$, firmar com os adquirentes das unidades autônomas o contrato definitivo necessário em decorrência de contratos preliminares.

\footnotetext{
${ }^{661}$ Nos termos do $\S 12$ de tal artigo: "Para os efeitos do $§ 11$ deste artigo, cada adquirente responderá individualmente pelo saldo porventura existente entre as receitas do empreendimento e o custo da conclusão da incorporação na proporção dos coeficientes de construção atribuíveis às respectivas unidades, se outro critério de rateio não for deliberado em assembléia geral por dois terços dos votos dos adquirentes, observado o seguinte: I - os saldos dos preços das frações ideais e acessões integrantes da incorporação que não tenham sido pagos ao incorporador até a data da decretação da falência ou da insolvência civil passarão a ser pagos à Comissão de Representantes, permanecendo o somatório desses recursos submetido à afetação, nos termos do art. 31-A, até o limite necessário à conclusão da incorporação; II - para cumprimento do seu encargo de administradora da incorporação, a Comissão de Representantes fica investida de mandato legal, em caráter irrevogável, para, em nome do incorporador ou do condomínio de construção, conforme o caso, receber as parcelas do saldo do preço e dar quitação, bem como promover as medidas extrajudiciais ou judiciais necessárias a esse recebimento, praticando todos os atos relativos ao leilão de que trata o art. 63 ou os atos relativos à consolidação da propriedade e ao leilão de que tratam os arts. 26 e 27 da Lei $\mathrm{n}^{\circ}$ 9.514, de 20 de novembro de 1997, devendo realizar a garantia e aplicar na incorporação todo o produto do recebimento do saldo do preço e do leilão; III - consideram-se receitas do empreendimento os valores das parcelas a receber, vincendas e vencidas e ainda não pagas, de cada adquirente, correspondentes ao preço de aquisição das respectivas unidades ou do preço de custeio de construção, bem como os recursos disponíveis afetados; e IV - compreendem-se no custo de conclusão da incorporação todo o custeio da construção do edifício e a averbação da construção das edificações para efeito de individualização e discriminação das unidades, nos termos do art. 44.”.

662، $\S 3^{-} \mathrm{Na}$ hipótese de que tratam os $\S \S 1^{\underline{\mathrm{o}}}$ e $2^{\underline{\mathrm{o}}}$, a Comissão de Representantes ficará investida de mandato irrevogável para firmar com os adquirentes das unidades autônomas o contrato definitivo a que estiverem obrigados o incorporador, o titular do domínio e o titular dos direitos aquisitivos do imóvel objeto da incorporação em decorrência de contratos preliminares."
} 
O parágrafo 18 do art. 31-F prevê que, realizada a venda, a Comissão deve usar os recursos obtidos para quitar obrigações trabalhistas, previdenciárias e tributárias, reembolsar aos adquirentes as quantias que tenham adiantado, reembolsar à instituição financiadora a quantia que esta tiver entregue para a construção, entregar ao condomínio o valor que este tiver desembolsado para construção das acessões de responsabilidade do incorporador, na proporção de cada um, entregar ao proprietário do terreno, se pessoa distinta da pessoa do incorporador, o valor apurado na venda, e, por fim, devolver à massa eventual saldo.

Continuada e devidamente concluída a obra, caso haja sobra de recursos, estes deverão ser direcionados à massa falida da incorporadora ${ }^{663}$. Se, ao contrário, os recursos não forem suficientes para conclusão da obra, os adquirentes que aportarem recursos deverão se habilitar na falência, com crédito privilegiado, conforme salienta Chalhub ${ }^{664}$.

No tocante à possibilidade de continuidade da obra, é com parcimônia que se deve avaliar eventual benefício, uma vez que a assunção de uma obra por pessoas não especializadas nessa atividade pode não ser efetiva, ou seja, a continuidade da obra pode ser prejudicada pela falta de experiência e patente vulnerabilidade técnica daqueles que a assumirem, colocando em risco a segurança dos adquirentes e dos demais envolvidos.

Reitere-se que, em caso de instituição de patrimônio de afetação, há regra própria, indicada no art. 43, VII ${ }^{665}$, para liquidação do patrimônio ${ }^{666}$.

${ }^{663}$ Conforme § 13 do art.31-F: "Havendo saldo positivo entre as receitas da incorporação e o custo da conclusão da incorporação, o valor correspondente a esse saldo deverá ser entregue à massa falida pela Comissão de Representantes.”.

${ }^{664}$ CHALHUB, Melhim Namem. Alienação fiduciária, incorporação imobiliária e mercado de capitais: estudos e pareceres, cit., p. 260.

${ }^{665}$ Conforme redação a seguir: "VII - em caso de insolvência do incorporador que tiver optado pelo regime da afetação e não sendo possível à maioria prosseguir na construção, a assembléia geral poderá, pelo voto de 2/3 (dois terços) dos adquirentes, deliberar pela venda do terreno, das acessões e demais bens e direitos integrantes do patrimônio de afetação, mediante leilão ou outra forma que estabelecer, distribuindo entre si, na proporção dos recursos que comprovadamente tiverem aportado, o resultado líquido da venda, depois de pagas as dívidas do patrimônio de afetação e deduzido e entregue ao proprietário do terreno a quantia que lhe couber, nos termos do art. 40; não se obtendo, na venda, a reposição dos aportes efetivados pelos adquirentes, reajustada na forma da lei e de acordo com os critérios do contrato celebrado com o incorporador, os adquirentes serão credores privilegiados pelos valores da diferença não reembolsada, respondendo subsidiariamente os bens pessoais do incorporador;".

666،VII - em caso de insolvência do incorporador que tiver optado pelo regime da afetação e não sendo possível à maioria prosseguir na construção, a assembléia geral poderá, pelo voto de $2 / 3$ (dois terços) dos adquirentes, deliberar pela venda do terreno, das acessões e demais bens e direitos integrantes do patrimônio de afetação, mediante leilão ou outra forma que estabelecer, distribuindo entre si, na proporção dos recursos que comprovadamente tiverem aportado, o resultado líquido da venda, depois de pagas as dívidas do patrimônio de afetação e deduzido e entregue ao proprietário do terreno a quantia que lhe couber, nos termos do art. 40; não se obtendo, na venda, a reposição dos aportes efetivados pelos adquirentes, reajustada na forma da lei e de acordo com os critérios do contrato celebrado com o incorporador, os adquirentes serão credores privilegiados pelos valores da diferença não reembolsada, respondendo subsidiariamente os bens pessoais do incorporador." 
Podem, assim, os adquirentes deliberar pela venda do terreno, das acessões e demais bens e direitos integrantes do patrimônio de afetação, com divisão do resultado da venda na proporção de contribuição de cada um, desde que depois de pagas as dívidas do patrimônio de afetação e deduzido e entregue ao proprietário do terreno a quantia que lhe couber.

Nessa hipótese, o parágrafo $9^{\underline{0}}$ do artigo em comento ${ }^{667}$ prevê que a Comissão de Representantes deverá prestar contas aos adquirentes, entregando-lhes o produto líquido da alienação, no prazo de cinco dias da data em que tiver recebido o preço ou parcela do preço.

Caso não se obtenha a restituição dos aportes efetivados pelos adquirentes, estes serão credores privilegiados pelos valores da diferença não reembolsada, respondendo subsidiariamente os bens pessoais do incorporador.

Dessa forma, depreende-se haver um procedimento muito específico na lei, em caso de falência ou insolvência do incorporador, que, apesar de determinadas fragilidades, como a que impõe decisões seriíssimas quanto à continuidade de obra ou à liquidação do patrimônio, e a que impõe pesadas atribuições à Comissão de Representante, é procedimento que visa a busca do interesse coletivo inerente à incorporação imobiliária, atividade que, repise-se, envolve vultosos investimentos e o pagamento antecipado pelos adquirentes.

Por fim, cabe ressaltar que as pessoas nomeadas para fiscalização do patrimônio de afetação não serão responsáveis pela qualidade da obra, por seu atraso ou por qualquer outra obrigação do incorporador ou construtor, respondendo, contudo, com culpa na fiscalização, como se pode verificar da análise do art. 31-C da lei ${ }^{668}$.

Ainda que não se trate de objeto deste trabalho, cabe ressaltar que o incorporador pode constituir propriedade fiduciária sobre terreno e acessões ${ }^{669}$, em garantia a eventual financiamento para as obras.

\footnotetext{
${ }^{667}$ A Comissão de Representantes cumprirá o mandato nos termos e nos limites estabelecidos pela deliberação da assembléia geral e prestará contas aos adquirentes, entregando-lhes o produto líquido da alienação, no prazo de cinco dias da data em que tiver recebido o preço ou cada parcela do preço.

668، Art. 31-C. A Comissão de Representantes e a instituição financiadora da construção poderão nomear, às suas expensas, pessoa física ou jurídica para fiscalizar e acompanhar o patrimônio de afetação.§ 1o A nomeação a que se refere o caput não transfere para o nomeante qualquer responsabilidade pela qualidade da obra, pelo prazo de entrega do imóvel ou por qualquer outra obrigação decorrente da responsabilidade do incorporador ou do construtor, seja legal ou a oriunda dos contratos de alienação das unidades imobiliárias, de construção e de outros contratos eventualmente vinculados à incorporação. § 2o A pessoa que, em decorrência do exercício da fiscalização de que trata o caput deste artigo, obtiver acesso às informações comerciais, tributárias e de qualquer outra natureza referentes ao patrimônio afetado responderá pela falta de zelo, dedicação e sigilo destas informações."

${ }^{669}$ Ressalte-se que a Lei $\mathrm{n}^{\mathrm{o}}$ 4.864/65 instituiu, no âmbito do sistema financeiro de habitação, a regulamentação da cessão fiduciária de crédito em garantia, tendo por objeto os direitos creditórios advindos da alienação de imóveis. A Lei $\mathrm{n}^{\circ}$ 9.514/97 estendeu a regulação da cessão fiduciária em garantia, que era prevista antes para bens móveis, pela Lei $n^{\circ} 4.728 / 65$.
} 
No caso da cessão fiduciária de crédito ${ }^{670}$, o cedente é tomador de empréstimo e cede créditos para garantia fiduciária da dívida. Geralmente, o incorporador é cedente, que obtém financiamento para a obra e tem, como crédito, os contratos celebrados com os adquirentes das unidades futuras.

Por se tratar de garantia fiduciária, a partir da averbação do contrato no Cartório de Registro de Imóveis competente, os créditos permanecem no patrimônio do financiador, não sendo afetados em caso de insolvência do devedor, aplicando-se os art. 49 e 119 da Lei de Falências ${ }^{671}$, já citados, e o art. 20 da Lei no $9.514 / 97^{672}$.

Merece destaque a inovação trazida pela Lei $\mathrm{n}^{\mathrm{o}}$ 9.514/97, que consiste na securitização de créditos imobiliários, operação muito utilizada para obtenção de recursos e realizada por titular de crédito, geralmente a incorporadora, que o desconta, para antecipar suas receitas, mediante cessão a uma companhia securitizadora, que irá fazer o crédito circular no mercado financeiro ou no mercado de capitais ${ }^{673}$, conforme explana Chalhub ${ }^{674}$.

A expressão "securitização" utilizada por nosso legislador advém do termo "securities" do direito americano, que significa "valores", "ações", referindo-se, portanto, a títulos mobiliários ${ }^{675}$.

\footnotetext{
${ }^{670} \mathrm{~A}$ cessão fiduciária é um dos meios importantes para fortalecimento do mercado de financiamento imobiliário, sendo que, nos dizeres de Chalhub, "a partir dos mais modernos mercados de financiamento imobiliários (...), o mercado secundário de hipotecas e de outros créditos imobiliários será operado por uma espécie de companhia especializada em comprar créditos, emitir títulos a eles correspondentes e colocá-los nos mercados financeiros e de valores mobiliários". Negócio fiduciário, cit., p. 369.

${ }^{671}$ Além do art. 119 da Lei de Falências, o parágrafo $3^{\circ}$ do art. 49 de referida lei excluiu dos efeitos da recuperação os créditos garantidos pela propriedade fiduciária.

672، Art. 20. Na hipótese de falência do devedor cedente e se não tiver havido a tradição dos títulos representativos dos créditos cedidos fiduciariamente, ficará assegurada ao cessionário fiduciário a restituição na forma da legislação pertinente. Parágrafo único. Efetivada a restituição, prosseguirá o cessionário fiduciário no exercício de seus direitos na forma do disposto nesta seção."

${ }^{673}$ Cabe ressaltar a distinção entre mercado financeiro e mercado de capitais, baseada na forma como os recursos financeiros transitam entre os que buscam formas de aplicar sua renda. Com base na doutrina de Uinie Caminha, o mercado financeiro "é o lugar onde o dinheiro é gerido, oferecido e procurado, por meio de canais de comunicação que se entrelaçam na formação de sistemas", caracterizado pela interposição de uma instituição financeira. Já o mercado de capitais é caraterizado pela desintermediação, ainda que haja um agente que promove, coloca e subscreve os valores mobiliários emitidos. Securitização, cit., p. 23 e ss. Cita a autora, ainda, que o mercado de capitais é dividido em primário e secundário, sendo aquele caracterizado pelo fato de que "aquele que necessita de recursos se coloca diretamente em contato com o financiador, através da emissão de títulos", e este é fase posterior ao mercado primário, pois, "a partir do momento em que são adquiridos no mercado primário, os títulos se tornam, via de regra, livremente negociáveis", sendo sua função principal dar liquidez aos títulos negociados no mercado de capitais.

${ }^{674}$ CHALHUB, Melhim Namem. Negócio fiduciário, cit., p. 236.

${ }^{675} \mathrm{~A}$ título de exemplo, o termo é usado no Chile e na Argentina (securitización) e na França a nomenclatura utilizada é "titrisation" e no direito espanhol "titulización", conforme explana CHALHUB, Melhim Namem. Negócio fiduciário, cit., p. 370. Em Portugal, preferiu-se "titularização".
} 
Segundo Uinie Caminha ${ }^{676}$, a securitização tem por finalidade a antecipação de receitas pelo originador, a segregação de ativos em outra sociedade, a emissão de títulos e sua venda a investidores, com a diluição dos riscos atinentes aos recebíveis, sendo operada da seguinte forma: o originador (no caso da incorporação imobiliária o incorporador) tem bens e direitos representados por contratos ou títulos e os cede a terceiro que receberá os ativos e emitirá títulos ou valores mobiliários lastreados em tais ativos.

Trata-se de operação que se utiliza da cessão de direitos creditórios que servirão de lastro para a emissão de títulos e é caracterizada, geralmente, pela segregação de tais direitos em patrimônio de terceiro.

A Lei $n^{o}$ 9.514/97 assim define: “operação pela qual tais créditos são expressamente vinculados à emissão de uma série de títulos de crédito, mediante Termo de Securitização de Créditos, lavrado por uma companhia securitizadora,(...)"677.

Há emissão de Certificado de Recebíveis Imobiliários (CRI), referentes a créditos imobiliários, sendo estes caracterizados como quaisquer créditos que se relacionem a financiamentos imobiliários ou que sejam garantidos por bens imóveis ${ }^{678}$.

As garantias atinentes a tais créditos e títulos, inclusive sua padronização ${ }^{679}$, são essenciais para constituição de um mercado robusto e que dê segurança àqueles que nele atuam.

Dessa forma, é essencial afastar as hipóteses que venham a prejudicar a segurança de tal mercado.

A segregação patrimonial, como analisado alhures, é meio eficaz para dar maiores garantias ao investidor, tratando-se de uma forma de garantia fiduciária prevista em nosso ordenamento jurídico, entre outras tantas que existem.

\footnotetext{
${ }^{676}$ CAMINHA, Uinie. Securitização, cit., p. 38-39 e 101.

${ }^{677}$ acordo com o seguinte artigo da Lei no 9.514/97: "Art. $8^{\circ}$ A securitização de créditos imobiliários é a operação pela qual tais créditos são expressamente vinculados à emissão de uma série de títulos de crédito, mediante Termo de Securitização de Créditos, lavrado por uma companhia securitizadora, do qual constarão os seguintes elementos: (...)".

${ }^{678}$ Nos termos do art. $6^{\circ}$ : "O Certificado de Recebíveis Imobiliários - CRI é título de crédito nominativo, de livre negociação, lastreado em créditos imobiliários e constitui promessa de pagamento em dinheiro.

${ }^{679}$ Chalhub, por exemplo, explica tal necessidade de homogeneização das condições operacionais e cita a padronização das garantias, conforme descrito nos arts. 17 e 22 da Lei no 9.514/97. Negócio fiduciário, cit., p. 237. Uinie Caminha, por sua vez, cita que "A qualidade do ativo que servirá de lastro à emissão tem grande importância no processo de securitização, pois, em última análise, a emissão terá as mesmas características desse ativo, especialmente no que diz respetio a termo, rendimentos e resgate. Vale salientar que quanto mais homogêneos os contratoslcréditos cedidos, mais fácil será seu agrupamento para posterior securitização.”. CAMINHA, Uinie. Securitização, cit., p. 109.
} 
Não obstante, a Lei $n^{\circ}$ 9.514/97 autoriza a instituição de titularidade fiduciária sobre os créditos que estiverem sendo vinculados aos títulos, mas não cria tal obrigação às empresas securitizadoras ${ }^{680}$, justamente como ocorre na incorporação imobiliária e na constituição do patrimônio de afetação.

Optando pela instituição de titularidade fiduciária, haverá segregação dos créditos relacionados aos títulos, com destinação à satisfação dos direitos dos que vierem a subscrever os títulos emitidos, vinculados aos créditos citados ${ }^{681}$.

Há grande proteção advinda da afetação do patrimônio, uma vez que nem a insolvência do originador dos créditos (o incorporador, no caso) nem a do securitizador podem, a priori, determinar que o patrimônio afetado responda por suas obrigações.

Não obstante, Uinie Caminha cita haver casos em que a securitização é estruturada de modo a coobrigar o securitizador pelas obrigações do veículo de propósito exclusivo, acessando-se outros ativos além dos segregados. Contudo, menciona a autora que, ainda que possa ser uma garantia maior ao investidor, há perda de uma de suas principais características, que é a delimitação exata do lastro dos títulos emitidos ${ }^{682}$.

Em suma, reitera-se o benefício advindo do patrimônio de afetação, também no que se refere ao mercado secundário, relacionado a cessão de crédito imobiliário e securitização.

\subsubsection{Financiamento da obra e a súmula 308}

A questão da coligação dos contratos na incorporação imobiliária pode ser discutida em razão do disposto no parágrafo 12 do art. 31-A da Lei de Incorporação ${ }^{683}$, uma vez que este define a responsabilidade exclusiva das obrigações assumidas pelo

\footnotetext{
${ }^{680}$ Conforme art. 9 já citado: “Art. $9^{\circ}$ A companhia securitizadora poderá instituir regime fiduciário sobre créditos imobiliários(...).”.

${ }^{681}$ Segundo Santos, J. A. Penalva, os créditos objeto do regime fiduciário devem se destinar exclusivamente à liquidação dos títuls que a ela estiverem afetadas, bem como ao pagamento dos respectivos custos de administração e obrigações fiscais. SANTOS, J. A. Penalva. Obrigações e contratos na falência, cit., p. 222.

${ }^{682}$ CAMINHA, Uinie. Securitização, cit., p. 55.

683،Art. 31-A (...) § 12. A contratação de financiamento e constituição de garantias, inclusive mediante transmissão, para o credor, da propriedade fiduciária sobre as unidades imobiliárias integrantes da incorporação, bem como a cessão, plena ou fiduciária, de direitos creditórios decorrentes da comercialização dessas unidades, não implicam a transferência para o credor de nenhuma das obrigações ou responsabilidades do cedente, do incorporador ou do construtor, permanecendo estes como únicos responsáveis pelas obrigações e pelos deveres que lhes são imputáveis.
} 
incorporador, construtor ou cedente de direitos creditórios decorrentes da comercialização das unidades, sem que haja transferência de tais obrigações ao credor de eventual financiamento ou cessionário de direitos creditórios para realização do empreendimento.

Assim, o financiador não assume nenhuma das obrigações ou responsabilidades do cedente, do incorporador ou do construtor, permanecendo estes como únicos responsáveis pelas obrigações e pelos deveres que lhes são imputáveis.

Caramuru indica, com razão, que não deve haver mesmo responsabilidade do financiador, pois este não se envolve diretamente com as obrigações da incorporação, exceção que se faz quando o financiador subroga-se nos direitos e obrigações, como no caso de assumir a posse do imóvel ou da unidade componente da edificação, por descumprimento ${ }^{684}$.

A lei define, assim, a isenção de responsabilidade do agente financiador em relação à incorporação, sendo esta de responsabilidade integral daqueles que participam de fato na administração do empreendimento e na construção.

Rosenvald $^{685}$, contudo, vai além e afirma, em razão da coligação dos contratos, a responsabilidade do financiador em casos de vícios redibitórios das edificações financiadas:

Da mesma maneira que a mutuante não pode ser considerada uma estranha em relação ao contrato consumerista para o qual os seus recursos são direcionados, também não poderá se furtar do dever de proteger futuros adquirentes em face de vícios redibitórios das edificações por ela financiadas. Em sentido análogo, a empresa que aliena um bem não se eximirá da obrigação de indenizar por danos causados pela empresa terceirizada que realizou a sua instalação(.... $)^{686}$.

Ainda que haja coligação de contratos, o legislador pretendeu reforçar a responsabilidade do incorporador, no que se refere às obrigações instituídas exclusivamente pelo incorporador ou construtor para realização do empreendimento.

\footnotetext{
${ }^{684}$ FRANCISCO, Caramuru Afonso. O novo regime jurídico dos contratos: das incorporações e do registro imobiliário e da alienação fiduciária em garantia, cit., p. 84.

${ }^{685}$ ROSENVALD, Nelson. As redes contratuais. Carta Forense, Rio de Janeiro, 02 set. 2011. Disponível em: $<$ http://www.cartaforense.com.br/Materia.aspx?id=7577>. >. Acesso em: $30 \mathrm{dez} .2013$.

${ }^{686}$ Veja-se, nesse sentido, que a Quarta Turma do STJ decidiu, ao julgar o REsp 738.071, que a instituição financeira era parte legítima para responder, juntamente com a construtora, por vícios na construção do imóvel cuja obra foi por ela financiada com recursos do Sistema Financeiro de Habitação (SFH), sendo quea responsabilidade do agente financiador deve ser analisada caso a caso, a partir da regulamentação aplicável a cada tipo de financiamento e das obrigações assumidas pelas partes envolvidas.
} 
A inclusão de tal artigo 31-A foi realizada por meio da Lei $n^{\circ} 10.931 / 2004$, que como citado, instituiu diversas outras proteções aos envolvidos na incorporação.

No sentido de fortalecer ainda mais as obrigações contraídas pelo incorporador, o Superior Tribunal de Justiça ${ }^{687}$, em 2005, editou a Súmula 308, que define que a hipoteca $^{688}$ do terreno e das acessões firmada entre construtora e agente financeiro, operação comum no mercado imobiliário, seja ela anterior ou posterior à celebração da promessa de compra e venda, não tem eficácia perante o adquirente do imóvel.

Tal Súmula define, assim, a ineficácia de hipoteca constituída em favor de financiador do empreendimento. Esse entendimento baseou-se, principalmente, nos princípios sociais do atual Código Civil brasileiro e mostrou-se necessário em razão de acontecimentos que mostraram a fragilidade de incorporadoras e empresas do ramo a partir da década de 90, sendo o caso ENCOL um estandarte da desproteção dos adquirentes.

Destaque-se que a inadimplência ou insolvência do incorporador afeta, obviamente, o pagamento da dívida contraída pelo incorporador, o que permite, ao financiador, a cobrança dos valores que lhe forem devidos, conforme permitido em lei. Tal direito enseja a execução e penhora de bens do devedor, bem como, havendo constituição da garantia da hipoteca, a própria execução hipotecária.

Neste último caso, a hipoteca, por abranger as acessões e construções, nos termos do art. 1.474 do Código Civil, acabava por afetar os direitos dos adquirentes.

Nesse sentido, e independentemente da coligação dos contratos, tornou-se premente a necessidade de se flexibilizar a eficácia erga omnes e a característica de direito real da hipoteca, de forma a proteger terceiros pelo inadimplemento do mutuário, definindo-se, pois, que o adquirente do imóvel não deveria se afetado por eventual crédito mal concedido, sob pena de se ferir a função social do contrato e da propriedade.

A boa-fé objetiva, preconizada no Código Civil, permeia a conduta dos contratantes, que devem não só agir de forma ilibada no tocante às suas obrigações, como também devem

\footnotetext{
${ }^{687}$ Ratificando entendimento que vinha sendo adotado por tal Tribunal, como no REsp 146659 / MG, Relator(a) Ministro CESAR ASFOR ROCHA, T4 - QUARTA TURMA, Data do Julgamento26/04/2000, REsp 316640 / PR, Relator(a) Ministra NANCY ANDRIGHI, T3 - TERCEIRA TURMA, Data do Julgamento 18/05/2004; REsp 557369 / GO, Ministro FERNANDO GONÇALVES, T4 - QUARTA TURMA, Decisão: 07/10/2004; REsp 651125 / RJ, Ministro CARLOS ALBERTO MENEZES DIREITO, T3 - TERCEIRA TURMA, Decisão: 02/09/2004, entre outros.

${ }^{688}$ Ressalte-se que a hipoteca é direito real sobre coisa alheia, definido no art. 1.125 do Código Civil, sendo, pois, diversa da alienação fiduciária, que é garantia sobre coisa própria.
} 
observar os chamados deveres anexos, sempre no sentido de colaborar com a outra parte, auxiliar, prestar informações e não prejudicar a execução do contrato pela outra parte.

Com base nos conceitos de socialidade do Código Civil, vislumbramos a maior interferência nos contratos privados e a extensão da eficácia de determinados contratos a terceiros, havendo, assim, a mitigação do princípio de que o contrato possui efeitos apenas inter partes, o que é confirmado pela teoria dos contratos em rede, contratos relacionados ou coligados.

Já foi visto que há contratos com interdependência funcional, que se relacionam com a consideração da eficácia na esfera de terceiros determinados ${ }^{689}$, e que, quando estamos diante de contratos ligados em uma rede contratual, as partes desses contratos têm a obrigação de colaborar para o funcionamento da rede. Nesse sentido, a boa-fé objetiva e os deveres dela advindos devem também se referir aos demais participantes da rede, afastandose, assim, a eficácia do contrato limitada às suas partes.

Merece destaque entendimento esposado pelo STJ no julgamento de 02.05.02, do Recurso Especial n 337.040, cujo relator foi Ruy Rosado de Aguiar:

(...)Quando se cuida de contratos coligados, as circunstâncias do negócio é que determinarão quais as relações entre eles, e quando um não pode permanecer sem o outro, de modo que o descumprimento da obrigação de um possa influir também na conservação ou extinção do outro, desfazendo-se o negócio total. (sic)

A Súmula 308 veio, de forma inteligente e justa, proteger os adquirentes também nessa esfera, pois estes não podem ter suas expectativas de aquisição de imóvel próprio, geralmente o sonho do brasileiro, frustradas por desorganização financeira do incorporador ou omissão do financiador, que poderia, exemplificativamente, assegurar-se da venda das unidades pelo empreendedor e fazer eficaz a cessão de créditos decorrentes de tal venda ${ }^{690}$.

\footnotetext{
${ }^{689}$ Conforme Judith Martins Costa, pois há "continuidade e interferência entre esferas de interesse, que se congregam, em múltiplas esferas na vida de relações contratuais". Em Reflexões sobre o princípio da função social dos contratos. Revista Direito $G V$, v. 1, n 1, maio 2005. Disponível em: <http://www.direitogv.com.br/subportais/raiz/RDGV_01_p041_066.pdf>.

${ }^{690}$ Esse foi um elemento mencionado em uma decisão do STJ nesse sentido: “(...) é negligente a instituição financeira que não observa a situação do empreendimento ao conceder financiamento hipotecário para

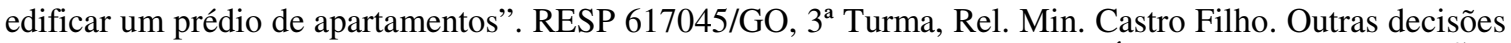
do STJ, que corroboram a Súmula 308: "CIVIL E CONSUMIDOR. IMÓVEL. INCORPORAÇÃO. FINANCIAMENTO. SFH. HIPOTECA. TERCEIRO ADQUIRENTE. BOA-FÉ. NÃO PREVALÊNCIA DO GRAVAME. 1 - O entendimento pacificado no âmbito da Segunda Seção deste STJ é no sentido de que, em contratos de financiamento para construção de imóveis pelo SFH, a hipoteca concedida pela incorporadora em favor do Banco credor, ainda que anterior, não prevalece sobre a boa-fé do terceiro que adquire, em momento posterior, a unidade imobiliária. Súmula 308 do Superior Tribunal de Justiça. 2 Recurso especial conhecido, mas não provido.”. REsp 557369/GO, Ministro FERNANDO GONÇALVES QUARTA TURMA 07/10/2004 e REsp 625045 / GO Ministro FERNANDO GONÇALVES QUARTA TURMA 17/05/2005, e outros sucessivos.
} 


\section{SÍNTESE DAS CONCLUSÕES}

Restou comprovada a proteção legal dos adquirentes de imóveis na incorporação imobiliária, carecendo a sociedade brasileira, no entanto, de conhecimento quanto aos direitos que lhe cabem e de acessibilidade ao Judiciário para enfrentar as grandes incorporadoras.

Para tal comprovação, foram analisados diversos aspectos atinentes à incorporação imobiliária e sua regulação pela Lei $n^{\circ}$ 4.591/64, bem como ao adimplemento de obrigações e à responsabilidade contratual.

Faz-se abaixo a síntese dos principais aspectos analisados e conclusões alcançadas no decorrer do estudo.

I. A atividade de venda de imóveis ainda em construção surgiu antes da regulação da incorporação imobiliária, ocorrida por meio da edição da Lei 4.591/64, o que ensejou, previamente à referida lei, a existência de cenário de completa desproteção dos adquirentes de imóveis em construção.

II. A Lei em questão, possuindo finalidade protetiva, estabeleceu diversas obrigações ao incorporador, inclusive prévias ao lançamento de um empreendimento.

III. Exemplificativamente, o incorporador deve registrar em Cártorio de Registro de Imóveis o memorial de incorporação, contendo informações claras sobre o empreendimento, inclusive projeto de construção, prazo para entrega das obras e custo (ainda que estimado, no caso da construção por administração).

IV. Ao incorporador são impostas as obrigações essenciais de promover a construção, dar andamento regular às obras, tomando todas as providências para que a edificação seja construída adequadamente, e de entregar a unidade autônoma devidamente construída, com observância do projeto de construção e das informações indicadas no memorial, transferindo-se a propriedade ao adquirente.

V. Verificamos que a obrigação do incorporador de entrega da coisa é obrigação de resultado.

VI. Em relação à entrega da obra, há definição de responsabilidade civil e penal (ainda que esta possa ser criticada em razão de sua baixa efetividade), em razão de 
paralisação da obra por mais de 30 dias de reatardamento excessivo de seu andamento, sem justa causa, não prejudicando o direito de o adquirente pleitear a execução específica, a resolução do contrato e os prejuízos advindos da mora e do inadimplemento, prevendo a lei procedimento específico para retomada das obras, que permite, ao fim, a destituição do incorporador.

VII. A entrega do imóvel no prazo acordado deve abranger a obtenção do habite-se e a averbação da construção, sem o que não há entrega adequada, por ferir a finalidade de uso do imóvel.

VIII. No tocante à coisa recebida pelo adquirente, restou demonstrada a proteção em relação a desconformidades, tanto pelo Código Civil quanto pelo Código de Defesa do Consumidor, em razão dos preceitos atinentes a vícios redibitórios, mau cumprimento e vícios de produto/serviço.

IX. Sem prejuízo, foram avaliadas as regras específicas quanto à diferença de área, concluindo-se que, ainda que não seja possível aplicar a regra do Código Civil, por se tratar a venda na incorporação imobiliária, geralmente, como "ad corpus", os preceitos atinentes à responsabilidade contratual e aqueles contidos no Código de Defesa do Consumidor podem suprir a necessidade do adquirente.

X. Verificou-se que se aplica à incorporação imobiliária a garantia de solidez e segurança da obra, prevista no Código Civil, sendo o prazo indicado no art. 618 prazo de garantia, podendo ser aplicadas, também, as regras do Código de Defesa do Consumidor, que, no geral, são tidas como mais favoráveis.

XI. A proteção relativa à hipótese de falência, recuperação, insolvência do incorporador foi prevista pelo legislador, por meio da Lei $\mathrm{n}^{\mathrm{o}} 10.931 / 2004$, que trouxe a possibilidade de instituição do patrimônio de afetação. Ainda que não seja obrigatória tal instituição, é extremamente comum sua utilização pelos incorporadores e benéfica, de forma que se pretende evitar o caos verificado pela falência da ENCOL.

XII. Com base nas obrigações legais decorrentes da Lei $n^{\circ} 4.591 / 64$, nos preceitos gerais atinentes às obrigações e na proteção prevista no Código de Defesa do Consumidor, verificou-se que os adquirentes são munidos de remédios em face de abusos do incorporador. 
Por fim, diante de todas as especificidades que envolvem este tipo de contratação, foram analisados os aspectos envolvendo a responsabilidade dos incorporadores por descumprimento de suas obrigações gerais e de determinadas obrigações que se refiriam à entrega da coisa, tanto atraso quanto impossibilidade, quanto aos vícios da coisa, de forma que, havendo proteção legislativa aplicável, conclui-se que a exposição dos adquirentes a problemas atinentes à entrega não se refere à carência legislativa material, sendo certa a dificuldade de acesso ao Judiciário para o adquirente fazer valer seus direitos.

Nesse sentido, indaga-se da necessidade de aprimoramento legislativo para coibir o descumprimento de obrigações pelo incorporador, o que se pode fazer por meio de sanções administrativas e civis mais veementes, especialmente atingindo diretamente o patrimônio do incorporador. 


\section{REFERÊNCIAS}

AGUIAR DIAS, José de. Da responsabilidade civil. 12. ed. Rio de Janeiro: Lumen Juris, 2011.

Responsabilidade civil em debate. Rio de Janeiro: Forense, 1983.

AGUIAR JÚNIOR, Ruy Rosado de. Extinção dos contratos por incumprimento do devedor: Resolução - de acordo com o novo Código Civil. 2. ed. Rio de Janeiro: Aide Ed., 2003.

ALMEIDA COSTA, Mário Júlio de. Direito das obrigações. 4. ed. Coimbra: Coimbra Ed., 1984.

ALVIM, Agostinho. Da inexecução das obrigações e suas consequências. 5. ed. São Paulo: Saraiva, 1980.

AMARAL, Francisco. Os atos ilícitos. In: MENDES, Gilmar Ferreira; FRANCIULLI NETO, Domingos (Coords.). O novo Código Civil: estudos em homenagem ao Prof. Miguel Reale. São Paulo: LTr, 2003. p. 147-163.

AMENDOEIRA JR., Sidnei. Execução, efetivação e cumprimento. In: BRUSCHI, Gilberto Gomes (Coord.). Execução civil e cumprimento da sentença. São Paulo: Método, 2006. p. 443-478.

AMORIM FILHO, Agnelo. Critério científico para distinguir a prescrição da decadência e para identificar as ações imprescritíveis. In: BARBOSA MOREIRA, José Carlos (Coord.). Revista Forense Comemorativa: 100 anos: direito processual civil. Rio de Janeiro: Forense, 2006. t. 5, p. 99-136.

ANDRADE, Fabio Siebeneichler. Considerações sobre o regime da prescrição no Código Civil de 2002 e seus efeitos quanto à Lei de Defesa do Consumidor. In: PFEIFFER, Roberto Augusto Castellanos; PASQUALOTTO, Adalberto (Coords.). Código de Defesa do Consumidor e o Código Civil de 2002: convergências e assimetrias. São Paulo: Ed. Revista dos Tribunais, 2005. p. 300-324.

ASSIS, Araken de. Resolução do contrato por inadimplemento. 5. ed. São Paulo: Ed. Revista dos Tribunais, 2013.

AVVAD, Pedro Elias. Condomínio em edificações no novo Código Civil. 2. ed. Rio de Janeiro: Renovar, 2007. 
AZEVEDO JR., José Osório de. Compromisso de compra e venda. São Paulo: Malheiros Ed., 2006.

AZEVEDO, Álvaro Villaça. Comentários ao novo Código Civil: das várias espécies de contrato: arts. 481 a 532. Coord. Sálvio de Figueiredo Teixeira. Rio de Janeiro: Forense, 2005. v. 2.

- Tradição e contrato de mútuo, de conta corrente e de compra e venda. Revista Forense, Rio de Janeiro, ano 103, v. 392, p. 3-10, jul./ago. 2007.

AZULAY, Fortunato. Do inadimplemento antecipado do contrato. Rio de Janeiro: Ed. Brasília, Ed. Rio, 1977.

BAPTISTA, Luiz Olavo. Construção civil e direito. Org. Luiz Olavo Baptista e Mauricio Almeida Prado. São Paulo: Lex Magister, 2011.

BATALHA, Wilson de Souza Campos. Loteamentos e condomínios: sistema jurídico da propriedade fracionada. 2. ed. Rio de Janeiro: Livraria Freitas Bastos, 1959. t. 1.

BESSA, Leonardo Roscoe. Vícios dos produtos: paralelo entre o CDC e o Código Civil. In: PFEIFFER, Roberto Augusto Castellanos; PASQUALOTTO, Adalberto (Coords.). Código de Defesa do Consumidor e o Código Civil de 2002: convergências e assimetrias. São Paulo: Ed. Revista dos Tribunais, 2005. p. 264-299.

BESSONE, Darcy. Da compra e venda promessa e reserva de domínio. 3. ed. São Paulo: Saraiva, 1988.

Direitos reais. São Paulo: Saraiva, 1988.

BEVILACQUA, Clovis. Direito das coisas. 5. ed. Rio de Janeiro: Forense, 1961.

BEZERRA, Elton. Conselho do MP veta TAC que permitia atraso em obras. Consultor Jurídico, 26 jun. 2012. Disponível em: <http://www.conjur.com.br/2012-jun-26/conselhomp-derruba-tac-permitia-construtoras-atrasar-entrega>. Acesso em: 19 set. 2013.

BORZUTZKY ARDITI, Alejandro. El derecho de superfície. Chile: Editorial Andres Bello, 1972.

BRITO, Rodrigo Azevedo Toscano de. Incorporação imobiliária à luz do Código de Defesa do Consumidor. São Paulo: Saraiva, 2002. 
BRITO, Rodrigo Azevedo Toscano de. Responsabilidade civil do construtor pela solidez e segurança da obra no sistema do Código Civil de 2002 e do Código de Defesa do Consumidor. In: DELGADO, Mario Luiz; ALVES, Jones Figueiredo (Coord.). Novo Código Civil: questões controvertidas. São Paulo: Ed. Método, 2003.

CAMBLER, Everaldo Augusto. Incorporação imobiliária: ensaio de uma teoria geral. São Paulo: Ed. Revista dos tribunais, 1993.

Responsabilidade civil na incorporação imobiliária. São Paulo: Ed. Revista dos Tribunais, 1998.

CAMINHA, Uinie. Securitização. São Paulo: Ed. Saraiva, 2005.

CARDARELLI, Sergio. L'acquisto di immobili da costruire o in corso di costruzione. Milano: Giuffrè, 2009.

CARRASCO PERERA, Ángel; CORDERO LOBATO, Encarna; GONZÁLEZ CARRASCO, Carmen. Derecho de la construcción y la vivienda. 4. ed. Madrid: Editorial Dilex, 2003.

CAVALIERI FILHO, Sergio. Programa de direito do consumidor. São Paulo: Atlas, 2008.

Programa de responsabilidade civil. 4. ed. São Paulo: Malheiros Ed., 2003.

CERVILLA DOMÍNGUEZ, Miguel. La responsabilidad civil de los agentes de la edificación. Madrid: Ed. Cedro, 2011.

CHALHUB, Melhim Namem. Alienação fiduciária, incorporação imobiliária e mercado de capitais: estudos e pareceres. Rio de Janeiro: Renovar, 2012.

. Da incorporação imobiliária. 2. ed. Rio de Janeiro: Renovar, 2005.

. Negócio fiduciário. 4. ed. Rio de Janeiro: Renovar, 2009.

CILENTO, Antonio. L'acquisto di immobili in costruzione tra rischio econômico e tutela della persona. Napoli: Edizioni Scientifiche Italiane, 2010. (Collana: Quaderni dela Rassegna di diritto civile).

COSTA, José Maria da. As obrigações solidárias. In: MENDES, Gilmar Ferreira; FRANCIULLI NETO, Domingos (Coords.). O novo Código Civil: estudos em homenagem ao Prof. Ives Gandra Martins Filho. São Paulo: LTr, 2003. p. 238-312. 
DINIZ, Maria Helena. Curso de direito civil brasileiro: direito das coisas. 19. ed. São Paulo: Saraiva, 2004. v. 4.

DUARTE, Nestor. Obrigações alternativas, divisíveis e indivisíveis. In: MENDES, Gilmar Ferreira; FRANCIULLI NETO, Domingos (Coords.). O novo Código Civil: estudos em homenagem ao Prof. Ives Gandra Martins Filho. São Paulo: LTr, 2003. p. 219-237.

FRANÇA, Rubens Limongi. Manual prático do condomínio. Rio de Janeiro: Forense, 1989.

Jurisprudência da compra e venda. São Paulo: Ed. Revista dos Tribunais, 1983. (Coleção RT - Jurisprudência, v. 14).

Teoria e prática da cláusula penal. São Paulo: Saraiva, 1988.

FRANCISCO, Caramuru Afonso. O novo regime jurídico dos contratos: das incorporações e do registro imobiliário e da alienação fiduciária em garantia. São Paulo: Juarez de Oliveira, 2005.

FRANCO, João Nascimento; GONDO Nisske. Incorporações imobiliárias. São Paulo: Ed. Revista dos Tribunais, 1972.

FRANCO, Vera Helena de Mello. Os contratos empresariais e seu tratamento após o advento do Código Civil de 2002. Revista de Direito Mercantil, Industrial, Econômico e Financeiro, São Paulo, v. 48, n. 151/152, p. 22-46, jan./dez. 2009.

FUNDAÇÃO PROCON-SP. Assunto: Incorporação (Construtoras e Incorporadoras). Disponível em: <http://www.procon.sp.gov.br/pdf/acs_construtoras_2008_2011.pdf>. Acesso em: 13 jun. 2012.

Construtoras mais reclamadas. Disponível em: <http://www.procon.sp.gov.br/noticia.asp?id=3027>. Acesso em: 13 jun. 2012. Ranking - CIPs. Incorporação (Construtoras e Incorporadoras). $1^{o}$ sem 2013. Disponível em: <http://www.procon.sp.gov.br/pdf/ranking\%20incorporadoras_2013.pdf>. Acesso em: 126 nov. 2013.

GARCIA, Leonardo de Medeiros. Código comentado de direito do consumidor. Rio de Janeiro: Ed. Impetus, 2005. 
GERMANOS, Luis Paulo. Condomínio especial por unidades autônomas de terrenos: desnecessidade de vinculação imediata do terreno à construção das unidades habitacionais. 2005. Dissertação (Mestrado) - Faculdade de Direito da Universidade de São Paulo, São Paulo, 2005.

GOMES, Orlando. Contratos. 24. ed. Rio de Janeiro: Forense, 2001.

Contratos. 26. ed. Rio de Janeiro: Forense, 2007.

Contratos. 26. ed. Rio de Janeiro: Forense, 2008.

Direitos reais. Coordenador Edvaldo Brito. 20. ed. atualizada por Luiz Edson Fachin. Rio de Janeiro: Forense, 2010.

GRINOVER, Ada Pellegrini et al. Código Brasileiro de Defesa do Consumidor: comentado pelos autores do anteprojeto. 7. ed. Rio de Janeiro: Forense Universitária, 2001.

et al. Código Brasileiro de Defesa do Consumidor: comentado pelos autores do anteprojeto. 9. ed. Rio de Janeiro: Forense Universitária, 2007.

GUALHANONE, Álvaro Luiz Damásio. O incorporador como empresa. Revista de Direito Imobiliário, São Paulo, v. 7, jan. 1981.

GUIMARÃES, Paulo Jorge Scartezzini. Vícios do produto e do serviço por qualidade, quantidade e insegurança: cumprimento imperfeito do contrato. 2. ed. São Paulo: Ed. Revista dos Tribunais, 2007.

LABORIAU, Miguel. Algumas considerações sobre o inadimplemento antecipado no direito brasileiro. Revista Trimestral de Direito Civil, Rio de Janeiro, ano 11, v. 42, p. 93130, abr./jun. 2010.

LEONARDO, Rodrigo Xavier. A Súmula n 308 e a adoção da teoria das redes contratuais pelo Superior Tribunal de Justiça. In: PEREIRA JÚNIOR, Antonio Jorge; JABUR, Gilberto Haddad (Orgs.). Direito dos contratos. São Paulo: Quartier Latin, 2006. p. 435-450.

LIMA, Frederico Henrique Viegas de. Condomínio em edificações. São Paulo: Saraiva, 2010.

LOUREIRO, Luiz Guilherme. Contratos no novo Código Civil. 2. ed. São Paulo: Ed. Método, 2005. 
LUCHEUX, Jean-Michel. Les garanties de l'acquéreur dans les ventes d'immeubles à construire. [S.1.]: L'auteur, 1968.

MARCHI, Eduardo da Silveira B. A propriedade horizontal no direito romano. 2. ed. São Paulo: Quartier Latin, 2006.

MARINO, Francisco Paulo de Crescenzo. Contratos coligados no direito brasileiro. São Paulo: Saraiva, 2009.

MARKY, Thomas. Curso elementar de direito romano. 8. ed. São Paulo: Saraiva, 1995.

MARQUES, Claudia de Lima. Contratos no Código de Defesa do Consumidor: o novo regime das relações contratuais. 6. ed. São Paulo: Ed. Revista dos Tribunais, 2011.

MARTINEZ, Pedro Romano. Cumprimento defeituoso: em especial na compra e venda e na empreitada. Coimbra: Almedina, 2001.

MARTINS, Lucas Gaspar de Oliveira. Mora: inadimplemento absoluto e adimplemento substancial das obrigações. São Paulo: Saraiva, 2011.

MARTINS, Raphael Manhães. Inadimplemento antecipado: perspectiva para sua aplicação no direito brasileiro. Revista Forense, Rio de Janeiro, v. 103, n. 391, p. 159-188, maio/jun. 2007.

MARTINS-COSTA, Judith. Reflexões sobre o princípio da função social dos contratos. Revista Direito $G V, \quad$ v. 1, $\mathrm{n}$ 1, maio 2005. Disponível em: <http://www.direitogv.com.br/subportais/raiz/RDGV_01_p041_066.pdf>.

MEIRELLES, Hely Lopes. Direito de construir. 8. ed. São Paulo: Malheiros Ed., 1990.

MELLO, Marcos Bernardes de. Teoria do fato jurídico: plano da existência. 12. ed. São Paulo: Saraiva, 2003.

MEZZARI, Mario Pazutti. Condomínio e incorporação no registro de imóveis. 3. ed. Porto Alegre: Norton Editor, 2010.

MEZZASOMA, Lorenzo. Il "Consumatore" acquirente di immobili da costruire fra diritto al risparmio e diritto all'abitazione. Napoli: Edizioni Scientifique Italiane, 2008. (Collana: Consumatori Oggi, 21).

MINISTÉRIO PÚBLICO DO DISTRITO FEDERAL E TERRITÓRIOS. Promotoria de Justiça de Defesa dos Direitos do Consumidor - Prodecon. Disponível em: $<$ http://www.mpdft.mp.br/portal/index.php/mpdft-acao/termos-de-ajustamento-de- 
conduta/3166-promotoria-de-justica-de-defesa-dos-direitos-do-consumidor-prodecon>. Acesso em: 19 set. 2013.

MONTEIRO DE BARROS, Washington. Curso de direito civil: direito das coisas. 41. ed. São Paulo: Saraiva, 2011.

Curso de direito civil: direito das obrigações. 34. ed. São Paulo: Saraiva, 2003. v. 5,2 pt.

Curso de direito civil: direito das obrigações: $1^{\text {a }}$ parte: das modalidades, das obrigações, dos efeitos das obrigações, do inadimplemento das obrigações. 32. ed. São Paulo: Saraiva, 2003.

MOREIRA ALVES, José Carlos. Direito romano. 5. ed. Rio de Janeiro: Forense, 1995. v. 2.

MP e SECOVI firmam TAC para incorporadoras incluírem nos contratos cláusulas sobre atraso em obras. Disponível em: <http://www.mp.sp.gov.br/portal/page/portal/noticias/publicacao_noticias/2011/outubro_2 011/MP\%20e\%20SECOVI\%20firmam\%20TAC\%20para\%20incorporadoras\%20inclu\%C $3 \%$ ADrem $\% 20$ nos $\% 20$ contratos $\% 20 \mathrm{cl} \% \mathrm{C} 3 \%$ A 1 usulas $\% 20$ sobre $\% 20$ atraso $\% 20 \mathrm{em} \% 20 \mathrm{obr}$ as>. Acesso em: 19 set. 2013.

NETTO LÔBO, Paulo Luiz. Comentários ao Código Civil: parte especial, das várias espécies de contratos, da compra e venda; da troca ou permuta; do contrato estimatório; da doação, arts. 481 a 564. São Paulo: Saraiva, 2003. (Coord. Antonio Junqueira de Azevedo; v. 6).

NUNES, Lydia Neves Bastos Telles. Dos efeitos dos vícios redibitórios à luz do Código Civil brasileiro e do Código de Defesa do Consumidor. Revista do Instituto de Pesquisas e Estudos, Bauru/SP, n. 29, p. 69-82, 2000.

PENTEADO, Luciano de Camargo. Direito das coisas. 2. ed. São Paulo: Ed. Revista dos Tribunais, 2012.

Figuras parcelares da boa-fé objetiva e venire contra factum proprium. Disponível em: <http://www.flaviotartuce.adv.br/secoes/artigosc/Luciano_venire.doc>. Acesso em: 17 jun. 2010.

PEREIRA, Caio Mário da Silva. Código de Defesa do Consumidor e as incorporações imobiliárias. Revista dos Tribunais, São Paulo, v. 84, n. 712, p. 102-111, fev. 1995. 
Instituições de direito civil: contratos. 16. ed. Rio de Janeiro: Forense, 2012. v. 3.

PEREIRA, Caio Mário da Silva. Instituições de direito civil: direitos reais. 18. ed. Rio de Janeiro: Forense, 2011. v. 4.

. Propriedade horizontal. Rio de Janeiro: Forense, 1961.

PEREIRA, Lafayette Rodrigues. Direito das coisas. Adaptação ao Código Civil por José Bonifacio de Andrada e Silva. 5. ed. Rio de Janeiro: Freitas Bastos, 1943. v. 1.

PETRELLI, Gaetano. Gli acquisiti di immobili da costruire. Milano: Ed. Ipsoa, 2005.

PINTO, Nelson Luiz Guedes Ferreira. Contrato de incorporação imobiliária. In: THEODORO JUNIOR, Humberto (Coord.). O contrato imobiliário e a legislação tutelar do consumo. Rio de Janeiro: Forense, 2002. p. 203-388.

PONTES DE MIRANDA, Francisco Cavalcanti. Tratado de direito predial. 2. ed. Rio de Janeiro: J. Konfino, 1953. v. 2.

Tratado de direito privado: parte especial. Rio de Janeiro: Ed. Borsoi, 1962. t. 38.

Tratado de direito privado. Campinas: Ed. Bookseller, 2003. t. 26.

POVEDA VELASCO, Ignacio M. Proteção do comprador no direito romano. São Paulo: Cultural Paulista, 2002.

RIZZARDO, Arnaldo. Condomínio edilício e incorporação imobiliária. Rio de Janeiro: Forense, 2011.

RIZZATO NUNES, Luiz Antonio. Comentários ao Código de Defesa do Consumidor. 4. ed. São Paulo: Saraiva, 2009.

RODRIGUES, Silvio. Reflexões sobre o condomínio geral e em edifícios. Dissertação (Concurso para a livre docência de Direito Civil). 1951. Faculdade de Direito da Universidade de São Paulo, São Paulo, 1951.

RODRIGUES JUNIOR, Otavio Luis. Código Civil comentado. Compra e venda. Troca. Contrato estimatório. Artigos 481 a 537. São Paulo: Atlas, 2008. (Coord. Álvaro Villaça Azevedo, v. 6).

ROSENVALD, Nelson. As redes contratuais. Carta Forense, Rio de Janeiro, 02 set. 2011. Disponível em: <http://www.cartaforense.com.br/Materia.aspx?id=7577>. Acesso em: 30 dez. 2013. 
SANTOS, J. A. Penalva. Obrigações e contratos na falência. 2. ed. Rio de Janeiro: Renovar, 2003.

SARMENTO, Daniel. A vinculação dos particulares aos direitos fundamentais no direito comparado e no Brasil. In: BARCELLO, Ana Paula et al (Orgs.). A nova interpretação constitucional: ponderação, direitos fundamentais e relações privadas. Rio de Janeiro: Renovar, 2003. p. 193-284.

SAVANNA, Lidia. La compravendita garanzia per vizi della cosa venduta e nuova tutela del consumatore. Torino: Giappichelli, 2007.

SECRETARIA MUNICIPAL DE NEGÓCIOS JURÍDICOS. Leis Municipais de São Paulo. Disponível em: <http://lei.prefeitura.sp.gov.br/paginasp.html>. Acesso em: 29 dez. 2013.

SILVA, Bruno Mattos e. Análise crítica da Súmula 308 do Superior Tribunal de Justiça: alcance, conclusões e perspectivas. Disponível em: $<$ http://jus.com.br/revista/texto/6869/analise-critica-da-sumula-308-do-Superior Tribunal de Justiça>.

SILVA, Clóvis do Couto e. A obrigação como processo. Rio de Janeiro: Ed. FGC, 2006.

SILVA, Jorge Cesa Ferreira da. A boa-fé e a violação positiva do contrato. Rio de Janeiro: Renovar, 2002.

SIMÃO, José Fernando. Prescrição e decadência: início dos prazos. São Paulo: Atlas, 2013.

SOLER PASCUAL, Luis Antonio. Los consumidores ante la adquisición de un bien inmueble en proyecto o en fase de contrucción. Disponível em: $<\mathrm{http}$ ://revistasocialesyjuridicas.files.wordpress.com/2010/09/03-tm-08.pdf>. Acesso em: 05 dez. 2013.

STOCO, Rui. Tratado de responsabilidade civil: doutrina e jurisprudência. 8. ed. São Paulo: Ed. Revista dos Tribunais, 2011.

Tratado de responsabilidade civil: doutrina e jurisprudência. 9. ed. São Paulo: Ed. Revista dos Tribunais, 2013.

TAVARES, André Ramos. Do princípio da liberdade em face da tutela do consumidor: uma abordagem constitucional. In: MARTINS, Ives Gandra da Silva (Coord.). As vertentes do direito constitucional contemporâneo. Rio de Janeiro: Ed. América Jurídica, 2002. p. 579-591. 
TEPEDINO, Gustavo. Multipropriedade imobiliária. São Paulo: Saraiva, 1993.

; SCHREIBER, Anderson. A boa-fé objetiva no Código de Defesa do Consumidor

e no novo Código Civil. In: TEPEDINO, Gustavo (Org.). Obrigações: estudos na perspectiva civil-constitucional. Rio de Janeiro: Renovar, 2005.

TERRA, Aline de Miranda Valverde. Inadimplemento anterior ao termo. Rio de Janeiro: Renovar, 2009.

TERRA, Marcelo. Alienação fiduciária de imóveis em garantia. Porto Alegre: Instituto de Registro Imobiliário do Brasil; Fabris, 1998.

THEODORO JÚNIOR, Humberto. Comentários ao novo Código Civil. Rio de Janeiro: Forense, 2003.v. 3, t. 2.

O contrato imobiliário e a legislação tutelar do consumo. In: (Coord.). $O$ contrato imobiliário e a legislação tutelar do consumo. Rio de Janeiro: Forense, 2002. p. 3-128.

Direitos do consumidor: a busca de um ponto de equilíbrio entre as garantias do Código de Defesa do Consumidor e os princípios gerais do direito civil e do direito processual civil. 7. ed. Rio de Janeiro: Forense, 2011.

TRIOLA, Roberto. Vendita di immobili da costruire e tutela dell'acquirente. Milano: Giuffrè, 2005.

VENOSA, Silvio de Salvo. O Código do Consumidor e o Código Civil. Publicado em: Valor Econômico, São Paulo, 23 abr. 2002. p. E2. Instituto Brasileiro do Direito do Seguro. Disponível em: $<$ http://www.ibds.com.br/artigos/OCodigodoConsumidoreoCodigoCivil.pdf>. Acesso em: 08 jan. 2014.

VIANA, Marco Aurélio da Silva. Vagas de garagem na propriedade horizontal: doutrina e jurisprudência. São Paulo: Saraiva, 1981. 